\title{
A Communion of Churches: Indian Christians, English Ministers, and Congregations in New England, 1600-1775
}

Gregory Alan Michna

Follow this and additional works at: https://researchrepository.wvu.edu/etd

\section{Recommended Citation}

Michna, Gregory Alan, "A Communion of Churches: Indian Christians, English Ministers, and Congregations in New England, 1600-1775" (2016). Graduate Theses, Dissertations, and Problem Reports. 6229.

https://researchrepository.wvu.edu/etd/6229

This Dissertation is protected by copyright and/or related rights. It has been brought to you by the The Research Repository @ WVU with permission from the rights-holder(s). You are free to use this Dissertation in any way that is permitted by the copyright and related rights legislation that applies to your use. For other uses you must obtain permission from the rights-holder(s) directly, unless additional rights are indicated by a Creative Commons license in the record and/ or on the work itself. This Dissertation has been accepted for inclusion in WVU Graduate Theses, Dissertations, and Problem Reports collection by an authorized administrator of The Research Repository @ WVU.

For more information, please contact researchrepository@mail.wvu.edu. 
A Communion of Churches: Indian Christians, English Ministers, and Congregations in New England, 1600-1775

\section{Gregory Alan Michna}

Dissertation submitted to the Eberly College of Arts and Sciences

at West Virginia University

in partial fulfillment of the requirements for the degree of

Doctor of Philosophy

in

History

Tyler Boulware, Ph.D., Chair

Joseph Hodge, Ph.D.

Brian Luskey, Ph.D.

Matthew Vester, Ph.D.

Edward Andrews, Ph.D.

Department of History

Morgantown, West Virginia

2016

Keywords: Native American, New England, Religion, Theology, Churches, Praying Towns, Natick, Indian Christians, Half-Way Covenant, Stoddard, Revivals, King Philip's War, Wheelock, Samson Occom, Race, Community, Puritan, Puritanism

Copyright @ 2016 Gregory Alan Michna 


\begin{abstract}
A Communion of Churches: Indian Christians, English Ministers, and Congregations in New England, 1600-1775
\end{abstract}

\title{
Gregory Alan Michna
}

This dissertation advances the study of New England's religious history by exploring the complex and contested religious discourse surrounding puritan ecclesiology and the conceptual place of Native Americans within physical and imagined communities. While relations between puritan missionaries such as John Eliot and Thomas Mayhew and early "Praying Indians," or Indian Christians, have been closely studied, this work draws attention to the importance of theology and religious discourse in realms like hermeneutics, ecclesiology, and eschatology in shaping the nature of these exchanges. Despite communal and cultural differences, religious culture frequently served as a means of bridging these gaps to foster amicable and meaningful relationships between English ministers and Algonquian-speaking Native Americans within the Massachusetts Bay Colony and its environs. At the same time, frustrations to actualize missionary communities like Natick in conformity with preconceived English ideals and violent altercations like King Philip's War were similarly filtered through a milieu of religious ideas to solidify early categories of difference which reinforced the exclusion and marginalization of Native Americans from religious spaces.

With the arrival of Separatists at Plymouth in 1620 and the first puritans at Boston in 1630, English settlers entered a region dominated by native power. Anthropological examination of both groups reveals the importance of community dynamics, harmony, and wellbeing to both Englishmen and Native Americans. Both groups faced various challenges during these early contact years in the form of conceptually placing their new neighbors within an ontological schema, navigating trade and diplomacy, and confronting internal challenges of schism and disease. The onset of civil war in England in 1642 created new millennialist impulses for select puritans in New England, who read transatlantic events as a sign of the impending apocalypse and set out to convert Native Americans in fulfilment of biblical prophecy. Native Americans faced tremendous violence and pressure from family members in making the decision to form new religious communities in partnership with these missionaries, which makes the religious impetus a significant factor in explaining indigenous decision-making.

The transition from civil polity to ecclesiastical polity took nearly a decade for Natick, and this work argues that these developments paralleled internal debates regarding puritanism and the Half-Way Covenant, validating indigenous religiosity in new ways, though these positive developments proved short-lived with the onset of King Philip's War and popular rhetoric portraying Indians as Canaanite heathens destined for destruction. The status of Indian Christians proved tenuous as the region entered the eighteenth century, though new developments by Solomon Stoddard created the potential to increase the boundaries of English religious communities to include Native Americans. The period of revivalism that swept New England from roughly 1735 to 1750 also raised questions about indigenous religious experiences and participation, leading to a strong critique from the antirevivalist faction. This long view of religious interaction adds more depth to the failure of mid-century missions by Gideon Hawley, John Brainerd, and Eleazar Wheelock. At the same time, Indian Christians like Samson Occom chafed against and challenged prevailing religious discrimination against their brethren. 


\section{Acknowledgements}

To appropriate a proverbial saying, it truly takes a village to raise a young scholar. Working through the challenges accompanying a dissertation-length research project would not have been possible without the aid of good music, conversations with close friends, unyielding support from family, and a steady flow of alcohol. I will attempt to address the people who deserve special consideration in due turn.

On the family front I must first thank my parents, Glenn Michna and Karen Stieff, for their support throughout my educational career. I'm proud of all that I have accomplished and none of it would be possible without your emotional and monetary support throughout these years of graduate school. I must also thank my sisters Emily and Gina for your support and willingness to talk about things far outside the bounds of my work over games of Cards Against Humanity during holidays. I also want to mention my brother Stephen, who did not live to see my completion. The time that you came up to West Virginia after Nathan was born was one of my best memories and I am glad that we have pictures of you holding him for the future. I think you would have felt a kindred connection to the struggle for community and acceptance that threads throughout this work, and I miss you dearly. A special thanks to my extended family as well for providing support from afar and conversation about my research during the times that we've been fortunate to all share the same room. Thank you Lacy for trading off childcare duties with our son Nathan during my frequent writing and research days, and special thanks for shouldering the burden of household maintenance while I have traveled to many archives and conferences.

I must also thank the scholarly community at West Virginia University, beginning with Tyler Boulware as the chair of my committee and director of my research project. Your affability and good-natured interest in a subject far outside the geographic and conceptual bounds of the colonial South has been greatly appreciated. I must also thank other faculty members who have served on my committee for your support, insightful reading and comments, and model as researchers and scholars. Thanks to Joe Hodge for pushing me to think broadly about British imperial history across the Atlantic, which has deepened this study tremendously. Thanks to Brian Luskey for serving as such a wonderful mentor during my time as a GTA and as a committee member. Though we vary greatly in our interests within the domain of cultural history, I greatly appreciate you introducing me to Kariann Yokota's book over the course of your graduate seminar, which led me to think at length about colonial anxiety. Special thanks to Matt Vester. You are probably one of the most intimidating and formidable scholars that I know, and I thoroughly appreciate your passionate support of my work and desire to push it to be the best work possible with your thorough markup of my draft. A special thanks is in order for Ted Andrews as an outside reader and authority in my field. I greatly appreciate your insight into my work and support of the project in looking to the future and a wonderful book manuscript. Thanks to all the wonderful graduate students in G14 and G13 for being awesome friends and classmates, especially Jake Ivey, Hal Gorby, Karina and Josh Esposito, Justin Power, Adam Zucconi, Katie Thompson, Kenny Kolander, Zac Cowsert, Chuck Welsko, Brandon Roos, Cassie Auble, Megan McGee, and Lindsey McNellis. I am sad that the days of First Friday sociability at the Morgantown Brewpub must now come to a close. 
Thanks also to Jan and Roger Wishau for opening your house to me in Naperville, IL while I spent an incredibly fruitful month at a short-term fellowship at the Newberry Library in Chicago, and thanks to all of the summer fellows I met there for your insightful comments on my work, especially John Hunt. I must also thank Priscilla Connors, Justin Power, and Jeff Wiesner for reading drafts of chapters and providing comments on aspects of the project throughout its course. A very special thanks is due to Jake Blosser at TWU for continuing to open your office and house to me as a friend and colleague throughout this process.

I must also thank the archival staff members at the various libraries and repositories that have made this research possible. The Jack Miller Center Short-Term Fellowship to the Newberry Library put me in touch with a number of scholars and staff members who were tremendously helpful in fetching secondary texts and countless primary sources for the reading room. The month of uninterrupted time to research and write at the library was absolutely invaluable to my work on the latter half of the dissertation. The Andrew W. Mellon Short-Term Fellowship at the Massachusetts Historical Society has provided access to fruitful research, and I cannot wait to return this summer to further expand the latter portion of this work in preparation for submission to publishers. A special thanks is due to Kate Viens at the MHS for her kindness and interest in bizarre finds of mine, such as sermons written in seventeenth-century coded shorthand. West Virginia University and the History department in particular deserve special thanks for providing generous funding to humanities scholars like myself to attend numerous conferences over the course of these years. The funding provided by the Doctoral Research Fellowship enabled me to travel to the John Carter Brown Library in Providence, RI, as well as the Dr. Williams' Library and archives of the Royal Society in London. I must also thank Becky and Martha in the department office for helping me navigate the ways of the department and for ensuring that my paperwork was always properly filed and deadlines were met.

Finally, my deepest and most heartfelt thanks go to my son Nathan, who provides a reason every day to be the best person that I can be, along with the most successful and hardworking in all that I do. I love you so much, and this is all for you. Carry the fire and always keep it burning. 


\section{Table of Contents}

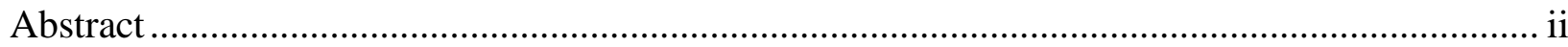

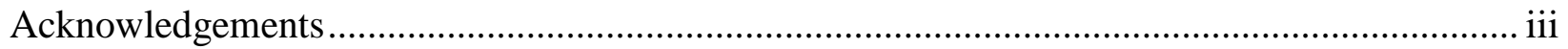

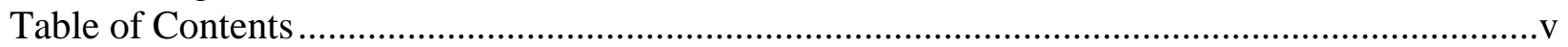

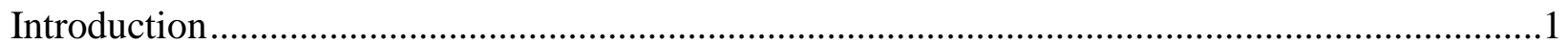

Chapter One

Manitou and Covenant: Religiosity in Native American and Puritan Communities....................22

Chapter Two

"Not Because I Loved God, But Because I Loved My Brothers": Kinship and the Origins of New

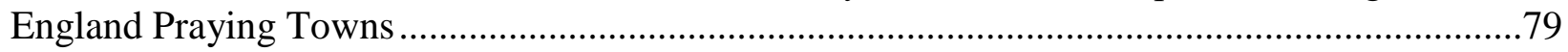

Chapter Three

The Long Road to Sainthood: Praying Indians and the Half-Way Covenant of 1662 ...............128

Chapter Four

King Philip's War as Holy War: Theologies of Difference and Typological Barbarism, 1675-

1700 .

Chapter Five

Open Tables and Closed Communities: Stoddardeanism, Indian Revivals, and the Corresponding Antirevivalist Critique, 1700-1750

Chapter Six

“Those Poor Benighted Pagans": Religious Cultural Divergence and the End of Colonial

Missions, 1750-1775

Conclusion

Facing Outward and Inward: The Dynamics of Colonial Theology and Religious Community

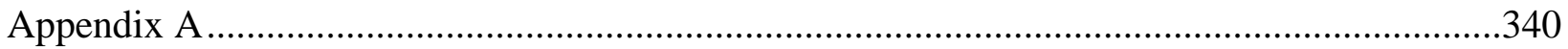

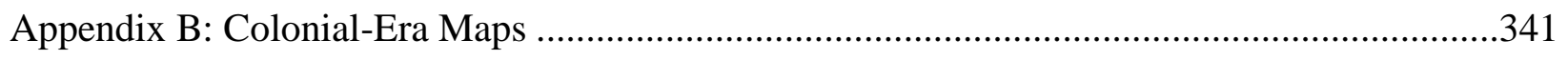

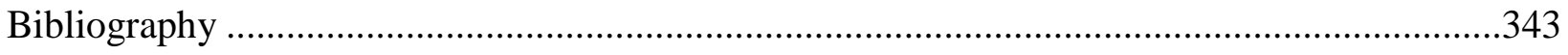




\section{Introduction}

Published on the cusp of the American Revolution, Timothy Dwight's The Conquest of Canaan (1785) laid out a new American vision in the form of an epic poem drawing on the Canaanite conquest under Joshua but designed "for universal application." Dense and plodding at times, Dwight's prolix epic nevertheless highlights common assumptions in his day about colonial history and the place of Indians within the early American republic. By drawing on the Israelite-Canaanite binary, Dwight positioned two cultures locked in a conflict steeped in religious significance - a notion common within New England thought regarding Native Americans by his day but more hotly contested in the earlier colonial period. ${ }^{1}$

In describing the visceral details of the scenery within his epic, Dwight constructed a landscape more fitting for the North American woodlands than the arid geography of the Levant with lines like "A tall, dark forest gloom'd the northern round.” As "the close thicket wrapp'd the ambush'd fierce," Dwight's "fell heathens bore their hapless prey." Despite barbaric attacks from the Canaanites, his heroes exhorted each other to ignore "the mockery of yon heathen's rage," for "This hand, though young, shall boast a conquering day/ Blind is wild rage, and pride an easy prey." ${ }^{2}$ They could take pride in the distinctions between themselves and their heathen enemies, for "Religion bids a new creation rise,/ Fragrant as spring, and fair as spangled skies./Thus, on the canvas, West, with raptur'd view,/ Sees new-born worlds his magic hand pursue." Indeed, the spiritual blessings the Israelites enjoyed generated pity for "the poor heathen" who was not "as bless'd as we."3 In the eleventh book, God directly intervenes with

\footnotetext{
${ }^{1}$ Timothy Dwight, The Conquest of Canäan; A Poem, In Eleven Books (Hartford: 1785), iii. Bill Templer describes the epic as "the literary embodiment of the regenerative mythology of the American frontier and the national ethos, a verse epic that glorifies murder of the indigenous native population in the name of Jehovah." Bill Templer, "The political sacralization of imperial genocide: contextualizing Timothy Dwight's The Conquest of Canaan," Postcolonial Studies 9 (2006), 360.

${ }^{2}$ Dwight, Conquest of Canäan, 2, 102, 184.

${ }^{3}$ Ibid., 56, 111.
} 
cataclysmic violence against Israel's enemies: "Now God's tremendous arm asserts his laws,/ Now bids his thunder and the righteous cause,/ Unfolds how Virtue saves her chosen bands,/ And points the vengeance doom'd for guilty lands. ${ }^{\circ 4}$ By painting a vision of divine conquest and westward expansion into benighted heathen lands, Dwight drew on cultural scripts that his readers would easily recognize.

In the context of this work, The Conquest of Canaan represents a culmination of religious thought regarding the place of Native Americans within shared spaces and ecclesiastical community. It is an endpoint in a process of cultural construction and religious discourse which served as a foundation for policies directed toward Native Americans by the new United States of America which placed Native Americans outside the boundaries of shared community. Throughout the colonial period, Englishmen and Indians contested competing ideas about Indian religiosity, the nature of joint participation in religious rituals and church bodies, and relied on theological and ecclesiological points to sharpen or blur these communal definitions. While early colonists in the seventeenth century drew on elements of biblical typology utilized by Dwight in 1785 to construct the pagan "other," this construction was by no means inalterable. ${ }^{5}$ Indeed, elements of puritan theology and theological innovations which developed in colonial New England - changes driven by or in formulated in the context of indigenous actions and religious participation - offered contested ideas about the potential for Englishmen to embrace Indians as their spiritual kin. ${ }^{6}$

\footnotetext{
${ }^{4}$ Ibid., 301.

${ }^{5}$ Arguments pertaining to indigenous inhabitants of North America typically came into play as justifications for conquest and the Aristotelian concept of native slavery. Anthony Pagden, The Fall of Natural Man: The American Indian and the Origins of Comparative Ethnology (Cambridge: Cambridge University Press, 1982), 38-41.

${ }^{6}$ Contemporary puritan scholarship also typically utilizes "puritan" rather than the proper noun "Puritan" in an effort to break from earlier conceptions of puritanism as a monolithic entity vis-à-vis Perry Miller's "New England Mind." The decentralized nature of congregationalism within New England ensured that practices and beliefs remained diverse on a localized basis, so long as they fell within overarching puritan norms.
} 
For the historian facing the sheer volume of writing pertaining to New England's colonial past in search of a dissertation topic it rightly deserves the adjective "morass." Exploring topics as diverse as Perry Miller's "Puritan Mind," lived history within New England villages, ministerial and popular piety, and clerical friendship, the puritan experience has long fascinated historians of early American history. ${ }^{7}$ With the introduction of the Atlantic paradigm, scholars have also linked Boston and Providence with the London metropole, as well as British holdings in the West Indies like Barbados. ${ }^{8}$ Epistolary networks forged by these developments similarly shaped intellectual and theological discussions across a wider puritan community, along with the transmission of missionary activity among Native Americans. ${ }^{9}$ New England puritanism itself was complex, multivalent, and the subject of a tremendous amount of ink dating back to the earliest New England puritans like John Winthrop and John Cotton, who sought to document and frame the nature of their sojourn. The restoration of Native Americans as actors equally important to history within this region has further complicated and enlarged the scope of study for subsequent historians.

Stories of survival, adaptation, resistance, and subversion from an indigenous perspective complicate colonial narratives in which Native Americans play little or no major role, severely

\footnotetext{
${ }^{7}$ See Francis J. Bremer, Clerical Communion: Clerical Friendship in the Anglo-American Puritan Community, 1610-1692 (Boston: Northeastern University Press, 1994), Shaping New Englands: Puritan Clergymen in Seventeenth-Century England and New England (New York: Twayne Publishers, 1994), and The Puritan Experiment: New England Society from Bradford to Edwards (New York: St. Martin's Press, 1976). See also Edmund S. Morgan, Visible Saints: The History of a Puritan Idea (Ithaca: Cornell University Press, 1987).

${ }^{8}$ Examples of relevant works that establish the Atlantic interrelationship between colony and metropole across economic, political, and cultural avenues include: John J. McCusker \& Russel B. Menard, The Economy of British America, 1607-1789 (Chapel Hill: University of North Carolina Press, 1985). Carla G. Pestana, The English Atlantic in an Age of Revolution, 1640-1661 (Cambridge: Harvard University Press, 2004). Rebecca Ann Bach, Colonial Transformations: The Cultural Production of the New Atlantic World, 1580-1640 (New York: Palgrave, 2000). ${ }^{9}$ Kathryn N. Gray, John Eliot and the Praying Indians of Massachusetts Bay: Communities and Connections in Puritan New England (Lewisburg: Bucknell University Press, 2013). Ann Kibbey, The Interpretation of Material Shapes in Puritanism: A Study of Rhetoric, Prejudice, and Violence (Cambridge: Cambridge University Press, 1986). Laura M. Stevens, The Poor Indians: British Missionaries, Native Americans, and Colonial Sensibility (Philadelphia: University of Pennsylvania Press, 2004).
} 
revising the work of the historiography's early filiopietists. ${ }^{10}$ Ethnohistorians have generated an important body of literature which pertains to the cultural trauma Native Americans faced, and the efforts taken by European governors and missionaries to effect social control, though more recent works have qualified the binary of admirable resistance and hated capitulation to explore the positive nature of cross-cultural communication and selective appropriation as a means of persistence and survival. ${ }^{11}$ Efforts to contextualize and understand culture as a product of particular temporalities and circumstances have brought religion and religious culture back to the forefront of historical study. Where earlier studies downplayed religiosity as high-minded afterthoughts compared to pressing worldly matters, scholars like David D. Hall have reintroduced religious beliefs and customs as integral to understanding the actions and thought processes of early colonial settlers. ${ }^{12}$

Finally, a growing body of historical literature has emphasized the importance of spatiality and geography as an important component to constructing community and identity,

\footnotetext{
${ }^{10}$ Dane Morrison, A Praying People: Massachusetts Acculturation and the Failure of the Puritan Mission, 16001690 (New York: Peter Lang, 1995), 186-89. Morrison explains Native American marginalization as a byproduct of "institutional intolerance" undergirded by latent racism. By portraying Eliot as uncompromising in his insistence that conversion by total in nature, Morrison deems the mission a "failure" (100-04). David D. Hall's edited volume Puritanism in Seventeenth-Century Massachusetts (New York: Hold Rinehard and Winston, 1968) offers a succinct examination of the shift away from this earlier historiographic tradition of the nineteenth century. Though culturally sensitive to restoring the importance of native actors, Alden T. Vaughan's New England Frontier: Puritans and Indians, 1620-1675, Third Edition (Norman: University of Oklahoma Press, 1995) has suffered criticism for its apologetic and overly favorable portrayal of the puritan side of colonial encounters.

${ }^{11}$ Seminal works in the conflict camp of indigenous histories include: James Axtell, The Invasion Within: The Contest of Cultures in Colonial North America (Oxford: Oxford University Press, 1985) and Neal Salisbury, Manitou and Providence: Indians, Europeans and the Making of New England, 1500-1643 (Oxford: Oxford University Press, 1984). Revision within this subfield is best exemplified by Daniel R. Mandell in Behind the Frontier: Indians in Eighteenth-Century Eastern Massachusetts (Lincoln: University of Nebraska Press, 1996), and David J. Silverman, Faith and Boundaries: Colonists, Christianity, and Community among the Wampanoag Indians of Martha's Vineyard, 1600-1871 (Cambridge: Cambridge University Press, 2005).

${ }^{12}$ Two relevant examples of studies which often subsume the religious proclivities of distinct colonial communities to worldly issues with Middle Colony Quakers are Frederick B. Tolles, Meeting House and Counting House: The Quaker Merchants of Colonial Philadelphia, 1682-1763 (New York: W.W. Norton \& Company, 1948) and Gary Nash, Quakers and Politics: Pennsylvania, 1681-1726, New Edition (Boston: Northeastern University Press, 1993). David D. Hall's Worlds of Wonder, Days of Judgment: Popular Religious Belief in Early New England (Cambridge: Harvard University Press, 1989) represents a seminal work which considers the intersection between religion and culture in colonial New England.
} 
which should be extended through a consideration of the conceptual nature of religious community at various times and places within a colonial setting. ${ }^{13}$ This dissertation places particular importance on the staying power of communal visions and efforts by Native Americans and English colonists to retain, modify, and outline their understanding of the world around them and their respective places. It is a study of imagined communities rooted in religion and theological concepts which changed across the span of the colonial period. While Benedict Anderson coined the term "imagined communities" in the context of nationalist analysis, he recognized the common overlap with religious thought. Communities are "imagined" in the sense that members thought in terms of shared connections across time and space while retaining "finite, if elastic, boundaries." They are communal in the sense that they stress "a deep, horizontal comradeship" despite the realities of inequality or exploitation. ${ }^{14}$ In early America, issues of theology and translation created discursive spaces and identities which Native Americans could utilize, modify, or reject. The very nature of this interaction often forced colonists to periodically reassess or redefine these notions of community to further incorporate or force out Native Americans depending on particular circumstances.

Renewed interest in Native American religious engagement has led scholars like Linford D. Fisher to promote the concept of "affiliation" over "conversion": the notion that indigenous

\footnotetext{
${ }^{13}$ See Jon Parmenter, The Edge of the Woods: Iroquoia, 1534-1701 (East Lansing: Michigan State University Press, 2010) and David L. Preston, The Texture of Contact: European and Indian Settler Communities on the Frontiers of Iroquoia, 1667-1783 (Lincoln: University of Nebraska Press, 2009). Both works highlight the importance of territorial control and the fluid nature of colonial power structures in shaping Iroquoian identity and relationships with English colonists. Similarly, Joshua Piker and Tyler Boulware emphasize the importance of towns as a locus for identity formation. Within a wider regional and ecclesiastical focus, these developments yield new information on Indian Christians as distinct people, living in distinct places, and their relationship with the wider ecclesiastical body of the colony. Joshua Piker, Okfuskee: A Creek Indian Town in Colonial America (Cambridge: Harvard University Press, 2004), Tyler Boulware, Deconstruction the Cherokee Nation: Town, Region, and Nation among Eighteenth-Century Cherokee (Gainesville: University Press of Florida, 2011).

${ }^{14}$ Benedict Anderson, Imagined Communities: Reflections on the Origin and Spread of Nationalism, New Edition (London: Verso, 2006), 6-13. Indeed, Anderson traced the framework of nationalist community to the roots of "religious imaginings," stressing that "sacred languages" defined religious community - a point worth considering in the context of translation efforts to render the Bible and other homiletic works into Algonquian languages. Anderson does however overstate the impact of the Enlightenment in shattering this religious framework.
} 
involvement primarily stemmed from practical concerns like obtaining literacy in order to shrewdly protect land and native culture. While Fisher's observations of native disengagement greatly support this thesis, this study reasserts the value of theological beliefs, shifts, and controversies across the span of colonial New England history to demonstrate that these developments created multiple opportunities and imperatives for participation from an indigenous perspective. ${ }^{15}$ As colonial history unfolded it similarly problematized the intellectual side of colonial religion, forcing English theologians and missionaries to grapple with indigenous interest and embrace or exclude them from religious fellowship. Similarly, Edward E. Andrews has traced the growing network of native missionaries, both Indian and African, and their connections to the larger missionary and ecclesiastical body operating in New England, the Caribbean, and Europe. ${ }^{16}$ This work adds a new component to Andrews' network by exploring with greater depth the English side of these exchanges and the impact which missionary work (and the special wrestling that missionaries had to do internally regarding the theological implications of their work) had on this network of clerical communicants and their hometown parishes.

By considering religious discourse an unstable aspect of English culture, prone to change and permutation as a result of colonial experiences, this work advances the cultural study of religious interactions within New England over an extended period of time. Throughout this work "theology" as a term is used in a holistic sense to cover intellectual religious discourse in areas such as formal theology, ecclesiology, eschatology, and hermeneutics, which all worked to systematically develop or hone religious beliefs over time. Rooted in a puritan understanding of

\footnotetext{
${ }^{15}$ Linford D. Fisher, The Indian Great Awakening: Religion and the Shaping of Native Cultures in Early America (Oxford: Oxford University Press, 2012).

${ }^{16}$ Edward E. Andrews, Native Apostles: Black and Indian Missionaries in the British Atlantic World (Cambridge: Harvard University Press, 2013).
} 
God as an omnipotent sovereign, these areas of religious discussion are all ultimately subsumed beneath God himself, which has led to a similar collapse under this general term to avoid unnecessary or cumbersome jargon. ${ }^{17}$ The focus on theological developments and their implications for Native Americans requires greater attention and analysis of New England sermons and the writings of ministers within the colony and in England in order to trace these developments. Sermonic literature took many forms: colonial histories like Cotton Mather's Magnalia Christi Americana, ordination sermons delivered as a charge to new missionaries to consecrate their work among Indians, dense theological tracts on the nature of conversion and spiritual regeneration in man, and platforms authored to give authoritative stances on mainstream doctrine. Though other historians have utilized many of these works to construct religious histories from an Anglocentric perspective, they are worth exploring with the question of indigenous placement and standing within the colony's ecclesiological body. Drew Lopenzina's concept of unwitnessing is a useful theoretical aid in doing so, which he likens to the way in which people block out traumatic experiences to maintain certain beliefs or to mitigate cognitive dissonance through silence, as well as the importance of "thick description" to cautiously investigate the unspoken significance of theological developments and their reliance on Native Americans. ${ }^{18}$ If puritan writers rarely explicitly relate doctrinal developments to Native Americans, subtextual connections are apparent.

\footnotetext{
${ }^{17}$ To give one extended example: There are areas in the text where specificity might dictate the use of the word "ecclesiology" to denote John Eliot's vision for church organization and membership. Despite this reality, Eliot's church arrangements at Natick and in texts like Communion of Churches seek to order the ecclesiastical body in a way deemed most pleasing to God himself. As such, Eliot's views on church membership make up a minor segment of his holistic theology. For this reason I have deemed the generic use of theology as a reflection of the conflation of many religious beliefs to be most appropriate to the text.

${ }^{18}$ Drew Lopenzina, Red Ink: Native Americans Picking Up the Pen in the Colonial Period (Albany: State University of New York Press, 2012), 9-10. "Thick description" as a concept comes from Clifford Geertz, The Interpretation of Cultures: Selected Essays by Clifford Geertz (New York: Basic Books, 1973), 3-30.
} 
Other scholars have examined the political, social, and economic landscape Praying Indians navigated over the course of colonial history. The balance of power and the nature of Indian autonomy which gave way to English ascendency has long driven studies of Indian use of the colonial courts and the English political system. ${ }^{19}$ While this work is rooted in a delicate awareness of these forces and their impact, this research considers these forces in the context of religious discourse and the decisions which Native Americans made in response to these theological changes. Similarly, studies of Indian efforts to maintain a land base also chart the shifting political ground and the consequences of changes for Indians as they attempted to maintain stable footing in an unstable political environment. The same can be said of religious interaction: while we often consider religious belief and doctrine to be stable and unchanging, the very nature of the colonial experience across multiple generations ensured that religious ideas, doctrine, and practice were adapted and reinvented in response to challenges, such as the growth of a new and largely unchurched second generation of Puritans in New England, the devastation of King Philip's War, and evangelical revivalism in the $1730 \mathrm{~s} .{ }^{20}$ As antirevivalists confronted the challenges they saw in revivalist religious practices, they sharpened the distinctions between Englishmen and Indians. New missionaries during this time betrayed an awareness of the conceptual link between revivalism and "heathen" Indian practices and subsequently tailored their missionary accounts to avoid association with revivalism's excesses. This work reveals paradoxical developments in colonial religious discourse derived from continued interactions between Englishmen and Native Americans: while visions of religious

\footnotetext{
${ }^{19}$ Jean M. O’Brien, Dispossession By Degrees: Indian Land and Identity in Natick, Massachusetts, 1650-1790 (Cambridge: Cambridge University Press, 1997). See also Daniel R. Mandell, Behind the Frontier and Jenny Hale Pulsipher, Subjects unto the Same King: Indians, English, and the Contest for Authority in Colonial New England (Philadelphia: University of Pennsylvania Press, 2005).

${ }^{20}$ On identity and King Philip's War, see: Jill Lepore, The Name of War: King Philip's War and the Origins of American Identity (New York: Vintage Books, 1998). Sarah Rivett's The Science of the Soul in Colonial New England (Chapel Hill: University of North Carolina Press, 2011) offers an evaluation of the role Native Americans played in shaping transatlantic discourses on natural philosophy and theology.
} 
fellowship expanded to create a more heterodox New England, Native Americans were edged out of this religious milieu by the persistent application of Calvinist doctrines that portrayed them as benighted heathens. As such, it joins a growing body of literature on the intersection of religion and race in early modern colonies pioneered most recently by Rebecca Anne Goetz's exploration of racial categories supported by religion in Virginia and Richard A. Bailey's examination of emergent racism in New England. ${ }^{21}$ What these works lack is a systematic examination of religious discourse and colonial theology as the dominant cultural factor in ongoing debates regarding Native Americans.

One way to envision religious belief and theology is as a door: at times facilitating interaction and passage between two places or cultures, it can also serve as a barrier between people and places. In diplomatic language, Native Americans frequently referred to paths which led to council fires. The natural movement of rocks and boulders, the washout from a stream, or human activity might obstruct the path at times. Each illustration points to the same concept and reflects an Indian and English worldview. Regardless of the metaphors employed, this dissertation is about the various ways in which religion in New England - a crucial aspect of Puritan and Native American cultures - acted in ways to facilitate meaningful connections. At other times it paradoxically served as the foundation for a convenient barrier between Englishmen and Indians or a justification for violence and condescension. In that sense, this work embraces David D. Hall's imperative to explore la religion veçue, or a sociological study of "lived religion" as a shaping component to human action. ${ }^{22}$ Robert Orsi argues that the study of lived religion "comes into being in an ongoing, dynamic relationship with the realities of

\footnotetext{
${ }^{21}$ Rebecca Anne Goetz, The Baptism of Early Virginia: How Christianity Created Race (Baltimore: Johns Hopkins University Press, 2012). Richard A. Bailey, Race and Redemption in Puritan New England (Oxford: Oxford University Press, 2011).

${ }^{22}$ David D. Hall, Lived Religion in America: Toward a History of Practice (Princeton: Princeton University Press, 1997), vii-viii.
} 
everyday life," as "people appropriate religious idioms as they need them, in response to particular circumstances. All religious ideas and impulses are of the moment, invented, taken, borrowed, and improvised at the intersections of life." ${ }^{23}$ For Algonquian-speaking Indians who sought to forge closer connections with the English and to enter into religious communion with them, most notably in the Praying Towns pioneered by John Eliot at Natick and Thomas Mayhew at Martha's Vineyard, religious culture proved a frustratingly transitory avenue to shared community and friendship with Englishmen. At times, it appeared that Indians were able to form meaningful connections within religious spaces that transcended cultural differences, while at other times religious culture served as a means of exclusion in the face of wider social and cultural issues.

This study considers puritans and their theology, traditionally thought to be inflexible and static, as flexible on certain points and a guiding aspect of New England culture which created discursive spaces for exchange with Native Americans who affiliated with ministers through attending sermons, residing in Praying Towns, and through ordination as indigenous ministers. It also explores the evolution and transformation of puritan theology as a byproduct of the colonial experience - continually informed by the presence of Native Americans within the colony as potential enemies, allies, and converts - that became even more complicated with the religious engagement of Native Americans. Religious discourse and dialogue with Native Americans and about Native Americans molded New England puritanism into a uniquely colonial religion. God's providential gift of salvation, a primitivist understanding of the church among the Gentiles, a millennialist eschatology, and a respect for personal encounters with the Divine

\footnotetext{
${ }^{23}$ Robert Orsi, "Everyday Miracles: The Study of Lived Religion," in Lived Religion in America: Toward a History of Practice, David D. Hall, ed. (Princeton: Princeton University Press, 1997), 7-8. Orsi urges scholars to continue to break down the artificial barrier between people in the past and our contemporary understanding of religion informed by modern existential orientations (14).
} 
(through conversion accounts, prophecy, and the like) opened Christianity to natives and shaped puritan understandings of indigenous encounters with their religion. Conversely, puritan theological constructs such as a corporeal devil, the Calvinistic doctrine of total depravity, and a tendency to fetishize sin could at times jettison natives from these spaces of cultural exchange, especially when Indian warfare and negative encounters with alcohol served to confirm the negative suspicions which many puritans simultaneously held. Throughout the course of colonial missionary projects in New England these theological tensions shaped the nature of missionary activity and contributed to the anxiety of colonists regarding the religious places and spaces which Praying Indians, or Indian Christians, inhabited. ${ }^{24}$

In approaching this tenuous and fluctuating religious "middle ground," Native Americans brought their own cultural concepts regarding religious practice, the influence of powerful spirits or "manitou" in the world, and the structural role which religious practice and observance played in indigenous society. ${ }^{25}$ Coupled with the language barrier that existed between English and Algonquian, these factors ensured that even with the overbearing and "culturally imperialist" stance affected by missionaries like John Eliot, Thomas Mayhew, or John Cotton, Jr., Massachusetts, Nipmucks, Wampanoags, and others were able to selectively shape the message and practice of Christianity into a distinctly indigenous form. ${ }^{26}$ The publication of Eliot's Indian

\footnotetext{
${ }^{24}$ As a minor semantic point, scholars like Linford Fisher have argued that historians reorder the conventional phrase "Christian Indian" as "Indian Christian" to reassert "Indian" as the core of identity for those engaged with missionaries. When an English perspective is utilized during earlier chapters the phrase "Praying Indian" is used to highlight the concept developed by missionaries like John Eliot, though this term fell out of vogue by the eighteenth century.

${ }^{25}$ The concept of a "middle ground" comes from Richard White's eponymous monograph: Richard White, The Middle Ground: Indians, Empires, and Republics in the Great Lakes Region, 1650-1815, Twentieth Anniversary Edition (New York: Cambridge University Press, 2011). At a conceptual level, the puritans' inability to fully control Native American engagement with religion forced them to adapt to indigenous expressions and appropriations of Christianity and refine their own thinking to incorporate colonial developments. As a conceptual space, this proved tenuous over the course of colonial history.

${ }^{26}$ On the role language played in these cultural exchanges, see: E. Jennifer Monaghan, Learning to Read and Write in Colonial America (Amherst: University of Massachusetts Press, 2005). Hilary E. Wyss, Writing Indians:

Literacy, Christianity, and Native Community in Early America (Amherst: University of Massachusetts Press, 2000),
} 
Bible, or Mamusse Wunneetupanatamwe Up-Biblum God, in 1663 ensured that this new

religious community conformed to existing linguistic and cultural markers of Native Americans

through its use of the Massachusetts dialect of Algonquian, as did the publication of other texts

in indigenous languages. In communities like Martha's Vineyard where indigenous populations

remained isolated for a far greater period of time than in mainland praying towns such as Natick

and Punkapoag, the maintenance of native ministers who carried out their charges in relative

autonomy ensured the survival and development of Indian Christian practices.

Studies of religious culture in early America frequently rely on conceptualizations of

theology and doctrine as a static aspect of culture; when change is recognized, it occurs within an

arena that remained the exclusive purview of European theologians and unfolded to meet internal

religious concerns. ${ }^{27}$ When external issues come into play, Native Americans rarely factor into

these developments. I depart from these patterns by regarding all aspects of religious culture as

inherently unstable and prone to affirmation, contention, and permutation as a result of the

instabilities engendered by colonialism. The participation of Native Americans in English

religious rituals and the wider ecclesiastical community, along with their appropriation and

incorporation of English lifeways as useful, meaningful, and a sign of shared community,

necessarily shaped colonial theology and religious practice. Native Americans presented

Patrick M. Erben, A Harmony of the Spirits: Translation and the Language of Community in Early Pennsylvania (Chapel Hill: University of North Carolina Press, 2012), and Kristina Bross, Dry Bones and Indian Sermons:

Praying Indians in Colonial America (Ithaca: Cornell University Press, 2004).

${ }^{27} \mathrm{R}$. Murray Thomas offers the most detailed anthropological comparison of the structure of belief and ritual for Native Americans and Englishmen, though the nature of such a project is necessarily broad and presents belief as somewhat static in Manitou and God: North-American Indian Religions and Christian Culture (Westport: Praeger, 2007)., Recent book by Bailey on race and religion and its issues, etc. Richard A. Bailey's analysis of the religious underpinnings of racial thinking and social order in puritan New England represents one of the best efforts to contextualize the development of religious thought and practice in a colonial setting, though the topical nature of his analysis inhibits the ability to show specific developments over time in Race and Redemption in Puritan New England (Oxford: Oxford University Press, 2011). Though a dated piece of scholarship, Frank Hugh Foster's “The History of the Original Puritan Theology of New England, 1620-1720" represents a fairly standard internal treatment of puritanism's colonial development with the occasional nod to outside forces such as Indian warfare and Anne Hutchinson. 
quandaries and challenges to colonial theologians and to puritan theology as a "lived religion," forcing them to debate and consider the extent and nature of Indian membership within this particular cultural community. Englishmen and Indians thus faced outward and inward to imagine their place within the wider colonial world in relation to its other inhabitants. By surveying religious interactions and theological developments over the course of the colonial period, this work deepens historians' understanding of lived theology and its development within New England as succeeding generations adapted and refashioned their intellectual and religious lineage to meet new concerns and to answer old questions.

This dissertation begins with an exploration of the interrelationship between religion and culture for both English and Algonquian-speaking people prior to sustained contact in North America. The pervasiveness of manitou within the physical world served as a powerful means of understanding natural phenomena and events within indigenous culture. Individuals and communities sought to harness this spiritual power in order to fulfill mundane needs, such as a good hunt or bountiful fishing, and they called on it during their most pressing crises when loved ones were dangerously ill or their village under attack by an enemy. Similarly, English puritans held distinct religious beliefs in addition to the more universally acknowledged aspects of Christianity, which set them apart from their Anglican brethren. While all puritans might agree on God's role in creating the world, the presence and problem of sin, and the necessity of Jesus's incarnation for salvation, puritans held to a fairly strict view of Calvinism in line with the Continental reformers at Geneva. In stressing mankind's total depravity after the Fall, the helplessness of salvation without God's act in bestowing grace, and the predestined fate of men, puritans contrasted these views with the practice of the Anglican church and sought to change them to remove the last vestiges of Catholic ceremony and complacency through varied types of 
reform. ${ }^{28}$ In their voyage to North America, puritans hoped to create a "citty upon a hill" - the subject of layman and future governor John Winthrop's "Modell of Christian Charity" sermon delivered aboard the Arbella. ${ }^{29}$ Thus, puritans set foot in Indian country with particular ideas of political and ecclesiastical polity derived principally from scripture and the importance of civil and church covenants. Religious culture necessarily structured interactions between puritans as they worked out the rough details of this model city amidst challenges from women like Anne Hutchinson and Thomas Morton, and it also structured their earliest interactions with the Indians they encountered.

The preoccupation with preserving and solidifying their own settlements meant that evangelism among the Indians was virtually nonexistent during the foundational decades of puritan settlement. For Native Americans, the arrival of Englishmen and disease microbes created a profound crisis within their societies as they grappled with massive epidemics which decimated their populations. People along the coast were the first victims, which prompted Indians to search for answers regarding the failure of their manitou to combat or challenge these mysterious new forces which plagued them. From the outset, some Indians proved interested in Christianity when they realized that English settlers fared far better against diseases. The second chapter thus explores the impulses and decision-making behind Indians to enter into a closer association with men like John Eliot, who began to preach to Indians in earnest as he learned Algonquian in advent of the coming Millennium. News of the English Civil War and puritan ascension under Cromwell served as the foundation for an apocalyptic eschatology which urged Eliot and Thomas Mayhew to proselytize to Indians in order to fulfill biblical prophecies.

\footnotetext{
${ }^{28}$ Flexibility and reform are the subject of one of David D. Hall's newest monographs entitled A Reforming People: Puritanism and the Transformation of Public Life in New England (New York: Alfred A. Knopf, 2011).

${ }^{29}$ John Winthrop, “A Modell of Christian Charity," in Collections of the Massachusetts Historical Society 3:7 (Boston: 1806), 47.
} 
Nevertheless, this theological impulse created a bridge between indigenous and English culture to a religious "middle ground" where Indians were welcomed to interact on a deeper level with the English. This interaction came with conditions, especially when Eliot proposed the creation of bounded, orderly towns such as Natick in 1650 . Here, Indians would enter first into civil organization and adopt English mores before forming an ecclesiastical polity.

From the perspective of the Massachusett, the decision to join the Natick community was not simply one of convenience or to protect land in the face of settler colonialism, though these forces were certainly at play. A close examination of kinship connections and the violence that often arose within extended families as a result of "conversion" or the decision to leave native villages and become a "Praying Indian" is important. The founding Praying Indians faced scorn for abandoning their manitou in favor of English spiritual power, threats on their physical lives (which sometimes materialized as dangerous attacks), warnings of spiritual calamity, and persistent efforts to bring them back within the fold. In short, this violence and pressure signifies the important repercussions inherent in the decision to migrate from one community in favor of another. This point serves to underscore the value and potential gain Praying Indians saw in the missionary project and the importance of allies or cultural brokers in negotiating a place for Indians amidst English settlement. ${ }^{30}$ Early testimonies written in missionary tracts by Eliot and others associated with the project also affirm the religious significance of the move to Natick, Punkapoag, and other towns, as reminiscences of loss and the message of salvation and protection within Christianity often moved Indian speakers to tears.

The third chapter examines the years of Praying Town expansion prior to King Philip's War and the theological issues at stake for ministers who considered validating Eliot's

\footnotetext{
${ }^{30}$ At a conceptual level, Indians were "not anchored in doctrine or exclusivity" like their European counterparts, so it proved easier to incorporate new ideas and knowledge about the religious world. Drew Lopenzina, Red Ink: Native Americans Picking Up the Pen in the Colonial Period (Albany: State University of New York Press, 2012), 21.
} 
missionary work and condoning the formation of an Indian church bound by an ecclesiastical covenant. By the middle of the seventeenth century, puritan theologians grappled with the issues surrounding the spiritual upbringing of their children in the context of the conversionary experiences they underwent in their youth. Similarly, the interest Indians showed towards aspects of Christianity complicated puritan thinking on this subject as they developed new ideas regarding spiritual lineages and a familial or tribal understanding of Christian identity. The development of colonial theology in this indigenous context factored into the issues surrounding the Half-Way Covenant of 1662, which conversely opened up new avenues of religious participation for Indian Christians. Within the long span of eight years between the founding of Natick as a physical town and the creation of a native church, Eliot and other ministers debated the nature of spiritual polity and the place of Indians within their wider religious community. By validating the gradual process of sanctification and religious transformation expected to play out in Indians, colonists simultaneously approved the new system for halfway members whose parents never fully "owned the covenant" and committed these children to a similar system of religious instruction. Puritan theologians grounded the concept of "theological preparation" in the parallel religious practices and actions of Native Americans who engaged Eliot and Mayhew during the formative missionary years, though they rarely explicitly acknowledged the relationship. At the same time, the linkage between unregenerate Indians and puritan children infantilized Indians and relegated them to a second-class theological status, which simultaneously sharpened distinctions between English Christians and Indian Christians.

Despite the actions Praying Indians took to legitimate their position within English society as fellow Christians - steps which included the creation of bounded towns, changes in diet and dress, religious instruction and significant growth in knowledge of Christian scriptures 
and doctrine - the crisis of King Philip's War posed new challenges. Historians now position the conflict as a "civil war" which forced Praying Indians to make difficult choices when choosing sides. ${ }^{31}$ Some of the nominally churched Nipmuc cast their lot with Philip, attacking colonial settlements and making overtures to other Praying Indians to abandon their English allies and join the uprising. Praying Indians like James Printer, who worked as a typesetter at the Cambridge press, willingly left and joined Philip and his allies, only to broker a return to the English side once the war had shifted against him. The outbreak of war placed Praying Indians in a complicated place, as they maintained a unique connection with Phillip himself through efforts to proselytize among his people. Individuals like John Sassamon found themselves in particularly dangerous roles, as Sassamon served Philip for a time as translator and scribe. Puritans initially interpreted the conflict theologically through the lens of biblical typology, drawing on Old Testament stories to shape colonial perceptions regarding Praying Indians.

Despite the best efforts of Praying Indians to prove themselves as allies and friends to the colonists, this theological shift undermined their legitimacy as true Christians to many colonists as they began to imagine Indians as savage and fallen. ${ }^{32}$ To many colonists, Praying Indians were only slightly more "civilized" than their unchurched kin, and the religious actions of the Praying Indians themselves were easily slighted as reminiscent of Catholic works which lacked any heart or true belief to substantiate them. While English allies of the mission sought to mitigate this invective, they failed to prevent their displacement to Deer Island and the sporadic and tragic acts of violence which sometimes targeted Praying Indians. As the colony began to assess the

\footnotetext{
${ }^{31}$ See Daniel R. Mandell, King Philip's War: Colonial Expansion, Native Resistance, and the End of Indian Sovereignty (Baltimore: Johns Hopkins University Press, 2010), and Jason W. Warren, Connecticut Unscathed: Victory in the Great Narragansett War, 1675-1676 (Norman: University of Oklahoma Press, 2014).

${ }^{32}$ Rebecca Anne Goetz similarly highlights the 1622 war between Indians and Englishmen in Virginia as a formative moment in the cultural divergence which fostered the creation of racial divisions in the minds of Englishmen in The Baptism of Early Virginia: How Christianity Created Race (Baltimore: Johns Hopkins University Press, 2012), 42-58.
} 
war and its impact, martyrological accounts of the Indian side of the war failed to gain cultural currency in the face of popular histories celebrating English victory over pagan savagery and tales of suffering under Indian captivity. Nevertheless, Praying Indians sought to rebuild their communities and continued to turn to religious culture as an important part of their lives as they entered the eighteenth century with scars from the horrors of the war and wariness towards many colonists.

Like the third chapter, the fifth explores the particular effects that a colonial setting and Native Americans played on the evolution of puritan theology in the eighteenth century. The advent of evangelical puritan revivals, occurring sporadically in England and the British colonies from 1735 to 1750 , created new opportunities for indigenous participation while simultaneously expanding the boundaries of religious community. Prior to these revivals, Indian Christians continued to persist as distinct communities with their own perspectives on religiosity. Puritan ministers continued to engage sporadically with these communities and played an important role as liaisons and helped establish the boundaries of their conceptual inclusion within the wider ecclesiastical body during this period. The sacramental innovations promoted by Solomon Stoddard as a response to the paradoxical nature of salvation and conversion within the puritan faith created new opportunities for indigenous religious participation, evidenced in the promotion and integration of elements of Stoddardeanism into the ministry of Experience Mayhew, who was the most widely published minister to succeed John Eliot in the early eighteenth century.

Within the open, positivist conception of grace and the converting role Stoddard afforded the sacraments of baptism (in the Half-Way Covenant) and communion as part of the morphology of conversion, Stoddard attempted to solve a perpetual issue within his faith: how to determine true election and assurance of salvation. As a missionary who desired conversionary 
breakthroughs among the Indians, Mayhew was encouraged to shift his thinking to embrace this theology because Stoddard offered a broad vision of conversionary grace which God extended to all men. Moving to the revivalism of 1735 to 1750 , the writings of missionaries John Sergeant and David Brainerd demonstrate the later application of Stoddard's theology in an indigenous context and the impact of revivalism on their writings. Revivalist Christianity, with its exuberant psalmody and emotive preaching and responses, offered new reasons to engage puritan religion, as it contained structural analogues which somewhat paralleled indigenous culture and appealed to native groups looking for stability in the changing colonial world. Antirevivalist criticisms demonstrate the staying power of the negative shift regarding indigenous religiosity, betraying a fear of religious and cultural degeneration. Antirevivalists worried that the irreverent and uneducated nature of revivalism held a corrosive effect on colonial orthodoxy. Set against theories of Indian degeneration and origins, revivalism played on colonial anxieties shaped by the continued presence of Indian neighbors, and the dialogue between revivalists and their critics helped to further sharpen the growing racialized divide between Englishmen and ethnic "others."

Chapter six analyzes the maturation of a theological conception of "race" in the latter portion of the eighteenth century, which crystalized in a term used with great frequency at this time: "poor, benighted Pagans." Anxieties regarding Indian Christians in the previous decades continued unabated, even within missionary circles, and shaped their conceptualizations of Indians in converted and unconverted states. As colonial warfare continued virtually unabated after King Philip's War, the tendency to view Indians as enemy “others" was bolstered by theological developments which emphasized the base characteristics of Indians when juxtaposed from an English ethnocentric position. Many ministers and colonists ironically held Indians to a more rigid, Calvinist understanding of conversion and election despite the diversification of 
religion within New England, positing that most Indians would be punished by God's wrath and waste away as a result of their failure to convert as the English imagined they should. Prominent Indian Christians like Samson Occom and Joseph Johnson faced high standards as exceptional Indians who God saved in the face of impossible odds. The doublemindedness that held Indians in such a low opinion tended to atomize these efforts when Indians struggled against the ills of colonialism and the inability for religion to bridge the widening cultural gap of their day. As missions moved to the margins of the expanding British Empire and many missionaries displayed the same callous attitude towards their fellow Indian Christian ministers, many “converted" Indians like Samson Occom rejected and reviled the ecclesiastical elements of English society and chose instead to form their own isolated, Christian communities in Oneida territory. Concluding before the American Revolution, this dissertation ends with a few final anecdotes regarding Indian Christians and evaluations of Indian religiosity within the early republic while drawing allusions to the modern-day significance of this work.

The paucity of indigenous writings during the seventeenth century ensures that the nature of these changes are predominantly described and commented on by English-speaking ministers, though there are moments where the sources permit exploration of indigenous piety and religious expression. Though the eighteenth and nineteenth centuries offer a greater source base of native writings, they are restricted to the select few Indians whose writings have survived in the archives. Samson Occom and William Appess were not the only Indians to voice their thoughts on religious topics, but they provide rare cases of native authorship and voicing with minimal filtration and interpretation through English eyes. Though this work principally focuses on the religious communities formed in mainland New England and their dynamics over time, the expanding nature of English settlement that accelerated after King Philip's War generated 
sources which reach beyond older communities like Natick, Punkapoag, and Monument Pond, as English ministers set their sights on new indigenous polities to spread their religious message. Thus, later missionary efforts by David Brainerd, John Sergeant, and Gideon Hawley play an important part in the regional history of New England missions even if they extend to Iroquoian territory and New York with the removes to New Stockbridge and Brothertown.

The guiding question this work seeks to unravel is what role did English colonial theology play in shaping interactions with Native Americans and how these beliefs changed over time to become "colonial" in nature: a true byproduct of cultural interplay which eventually became more exclusionary toward Native Americans. 123 years before Dwight published The Conquest of Canaan, another New England minister named Michael Wigglesworth published his own epic poem titled The Day of Doom: or, A Poetical Description of the Great and Last Judgment (1662), which similarly captured the spirit of its day. Wigglesworth attempted to shock his audience into religious action by portraying the impending apocalypse across 224 gruesomely imagined stanzas depicting mankind's final judgment. This same theological spirit prompted John Eliot to begin proselytizing among the neighboring Massachusett in 1646 along with similar efforts on Martha's Vineyard to launch the region's first major missionary endeavor. By the middle of the eighteenth century a similar millennialism pushed evangelical revivalists to reengage with similar projects, but on a much smaller scale and with far less support due to an accumulation of theological shifts and developments which edged out Native Americans from religious fellowship. 


\section{Chapter One \\ Manitou and Covenant: Religiosity in Native American and Puritan Communities}

The image of God in man was both inward and outward. The inward is the perfection of body and soul ... The external perfection of man consisted of his dominion over other creatures so that he might use them freely to the glory of God and for his own necessity.

William Ames ${ }^{1}$

The sociablenesse of the nature of man appeares in the wildest of them, who love society; Families, cohabitation, and consociation of houses and townes together.

\section{Roger Williams ${ }^{2}$}

The Great Spirit Cautantowwit (or Kiehtan), who ensured the harvest of beans and corn by sending warm winds from the South-West sky beyond the mountains, reached down onto the earth and picked up a hard granite stone. He began to sculpt it, shaping and forming the rock until the outlines of a man and a woman emerged from the stone. Cautantowwit looked at the figures that he had made and scowled in displeasure, smashing the man and woman into tiny pieces. He looked about and entered the nearby forest, where he took a tree and carved yet another man and woman, who were the parents of the Narragansett. But Cautantowwit was not the only spirit inhabiting the marvelous world of the ninnimissinouk (Algonquian for "people"). Keesuckquànd, the sun spirit, gave warmth to them in the summer months, while Nanepaûshat, the spirit of the moon, gave light to travelers in the night. Paumpágusfit animated the roiling and turbulent sea, while Yotáanit inhabited every saving fire that kept a body warm during the harsh winter months. These are just a few of the manitou who left their mark on the physical world. In death, the Narragansett looked forward to rejoining Cautantowwit with their loved ones in his great house, set apart from the spirits of murderers, liars, and thieves who wandered aimlessly in

\footnotetext{
${ }^{1}$ William Ames, The Marrow of Theology [1629], John Dykstra Eusden, trans. from Third Latin Edition, The Marrow of Theology: William Ames (1576-1633) (Grand Rapids: Baker Books, 1997), 106

${ }^{2}$ Roger Williams, A Key Into the Language of America: or, An help to the Language of the Natives in that part of America, called New-England (London: Gregory Dexter, 1643), 135.
} 
darkness. ${ }^{3}$ Their neighbors also told stories of the powerful Abbomocho (or Chepi) and his trickery and mastery over the darkness that kept people huddled indoors after nightfall. Abbomocho was associated with dark things and powerful new objects, and roared with thunder and lightning when roused to fierce anger. When they died they also hoped to travel to the SouthWest, where they would live in lush gardens, filled with abundant cornfields and cool rivers; this would be much better than travelling to Abbomocho's house, where they would be tortured for eternity. ${ }^{4}$ Some held that the manitou formed men and women to live together and have children, but the bad behavior of their descendants made the manitou mad, so the sea rose to drown most of them. ${ }^{5}$ So their fathers told them.

Newcomers told their stories in a different way:

In the beginning there was simply God. He began by forming the heavens and the earth, out of the expansive void of nothingness, followed by light and darkness. He separated dry land from the waters and covered it with plants and animals. To care for and tend to this creation, God made man "in our image according to our likeness," forming him "of the dust of the ground" and breathing life into him. However, God realized that this man was unique among all of creation, saying "it is not good that the man should be himself alone: I will make him a help meet for

\footnotetext{
${ }^{3}$ This creation story is adapted to a narrative style from Roger Williams' A Key Into the Language of America, as he sought to ascertain the religious beliefs of the Narragansett in what is today Rhode Island. Williams, A Key Into the Language, 150, 154, 157-58.

${ }^{4}$ William Wood, New England's Prospect [1634]. Publications of the Prince Society (Boston: John Wilson and Son, 1865), 86, 104-105. Kathleen J. Bragdon writes that Abbomocho appeared in many forms, typically an eel or snake, and was associated with the underwater realm. His powers were substantial and could waver between beneficial and malevolent, depending on the situation. Kathleen J. Bragdon, Native People of Southern New England, 1500-1650 (Norman: University of Oklahoma Press, 1996), 189. Traveler John Josselyn also noted that serpents were associated with powerful manitou or Abbomocho. A specific example from Josselyn's account is found below in the section on manitou and their earthly connections. John Josselyn, An Account of Two Voyages to New-England, Made during the years 1638, 1663 By John Josselyn Gent. [1673] (Boston: William Veazie, 1865), 22.

${ }^{5}$ Thomas Morton, New English Canaan. Publications of the Prince Society (Boston: John Wilson and Son, 1883), 167.
} 
him." So God caused the man to fall into a deep sleep, taking from him a rib which he used to make a woman and brought her to the man. When he saw the woman the man said "This now is bone of my bones, and flesh of my flesh. She shall be called woman, because she was taken out of the man." However, the perfection of God's creation was not to last, for God had commanded the man to eat freely of every tree in the garden except for the tree of knowledge of good and evil. The most subtle beast of the field, a serpent, tricked the woman into eating of the tree, and she gave the fruit to her husband to eat as well. They realized that they were naked and hid themselves from God when he called on them. Recognizing what they had done, God issued a separate curse for the man, woman, and serpent, casting them out from the Garden of Eden for all eternity to live a life of toil and hardship. ${ }^{6}$ The world mankind lived in was now corrupt and imperfect, awaiting the day when God would send his son to "break thine head" of the serpent. ${ }^{7}$ God's omniscience ensured that he would know who was among the elect, who could rejoice in the fact that reunion with deceased loved ones awaited them in Heaven. There they could enjoy eternal communion with the maker of the heavens and the earth. Others were predestined to Hell, where Satan would torture them for all eternity for their wicked sins.

\section{Community Matters}

From both of these anecdotes explaining the origins of the cosmos and mankind's place within it, human connections are at the forefront of the religious experience and form the

\footnotetext{
${ }^{6}$ This is a paraphrase of Genesis 1-3:24. All direct quotes are taken from the 1599 Geneva Bible, which was the version most commonly used by Puritans and Separatists, in contrast to the later King James Bible of 1611. 1599 Geneva Bible: The Holy Scriptures Contained in the Old and New Testaments (White Hall: Tolle Lege Press, 2007), 1-6. The Geneva Bible is a unique resource for Puritan studies because it also included a running commentary, reflective of Puritanism's Calvinist strain of theology. The note for Genesis 1:26 expounds that "man was created after God in righteousness and true holiness," while the footnote for 1:28 explains that "the propagation of man is the blessing of God" in explicating God's command to work and subdue the earth. These footnotes are influential in understanding the particular interpretive framework which Puritans utilized when reading the bible.

${ }^{7}$ Ibid., 6. Puritans understood the serpent in the bible's creation story to be Satan, God's chief adversary. Within the curse of Adam Puritans recognized that God promised "Satan shall sting Christ and his members, but not overcome them," per the footnote for Genesis 3:15.
} 
foundation of society irrespective of its particular nature. ${ }^{8}$ Algonquian-speaking Native

Americans, including the Massachusett, Nipmuck, Narragansett, Pequot, as well as the puritans, all recognized that humans were inherently social; their origin stories and religious beliefs explain not only the beginnings of mankind, but also the cosmological forces shaping interactions between others in community and powerful supernatural beings. Without the presence of men and women, there would be no community. Furthermore, religious belief and practice where inexorably linked to society and its corresponding political structures for both Native Americans and puritans when they first met and interacted in colonial New England. This chapter argues that community ideals and beliefs influenced and shaped the nature of contact and cohabitation during the seventeenth century for both groups, albeit in differing ways. Ideas and perceptions mattered, even more so as tensions rose, and both societies drew on religious belief to shape their decision-making. For Native Americans, communal health and its maintenance were paramount concerns when responding to political negotiations with puritan leaders, the effects of disease epidemic, and the ravages of warfare. Some groups, the Massachusett and Nipmuck in particular, found themselves more hard pressed to maintain group solidarity and cohesion as they faced the vanguard of puritan settlement in comparison to more distant groups

\footnotetext{
${ }^{8}$ Representative of structuralism and early anthropology, Emile Durkheim's analysis of "primitive" religion in The Elementary Forms of The Religious Life suggests that religious practice and belief serves as a fundamental part of society in its simplest organization. Durkheim suggested that these foundational elements that underlay the most complex beliefs and religion "have the same objective significance and fulfil the same functions everywhere." Emile Durkheim, The Elementary Forms of the Religious Life (New York: The Free Press, 1965), 17. Similarly, Max Weber suggests that religion binds members together into communities, despite the tension between religious leaders and lay members, and that the formation of a religious community is important in insulating members and setting them apart from outsiders. Max Weber, The Sociology of Religion. Ephraim Fischoff, trans. (Boston: Beacon Press, 1964), 65, 70. Likewise, Peter L. Berger goes further in attempting to systematize the study of religious connections in society by laying out a sociological theory of religion in The Sacred Canopy. In this work he suggests that religion serves the function of ordering society, heightening the negative effect of acting counter to such a society. He also suggests that religion's role in forming the base or "plausibility structure" of society is crucial to ordering reality, as any challenge or interruption to this social process "throws the reality of the worlds in question." When considering the effects of disease epidemics on native communities, this concept is particularly appropriate. Peter L. Berger, The Sacred Canopy: Elements of a Sociological Theory of Religion (Garden City: Anchor Books, 1967), 39, 45.
} 
like the Mohegan. Powwows and shamanic efforts to harness powerful manitou, or spirits, represented the most common native religious response. For puritans, the very nature of their "errand into the wilderness" placed a particularly religious focus on settlement and the establishment of the Massachusetts Bay Colony as an experiment that would culminate in the religious reformation of England and the Anglican Church. In a colonial setting, puritan leaders expected to reify idealized and theoretical beliefs about community and polity, and Calvinist theology formed a potent lens through which puritans conceptualized themselves, the world around them, and their place within it. Puritans likewise imbued everyday occurrences, signs, and natural wonders with great cosmological significance. These beliefs would equally shape the way puritans engaged neighboring Native American communities. Thus, religious culture and theology played a crucial role in the early colonial history of New England and overwhelmingly shaped cultural interactions between puritans and Native Americans.

Ideas about community were important to both Native Americans and puritans, both as a concrete body of individuals and a concept that established order and place, serving as the foundation for interactions amongst themselves and with outsiders. Individual connections formed the sinew of communities, along with the corresponding political, social, and religious practices and institutions that bound people together in native society, setting them apart from others who were outside its bounds. ${ }^{9}$ Communities also faced inward, regulating the behavior

\footnotetext{
${ }^{9}$ Recent scholars, particularly in Iroquoian studies, have emphasized the importance of settlement and spatial constructs in both Native identity and in responding to and shaping European colonization and interaction. Jon Parmenter's The Edge of the Woods: Iroquoia, 1534-1701 asserts that the Iroquois modified settlement patterns and enlarged their spatial domain to creatively meet the challenge of European settlement. Thus, movement and settlement were strategic methods of facilitating Iroquoian community health and power. Jon Parmenter, The Edge of the Woods: Iroquoia, 1534-1701 (East Lansing: Michigan State University Press, 2010), xii, xxvii-xxviii. Similarly, David L. Preston has emphasized the blurred nature of boundaries and settlement in colonial history, particularly in places where the Iroquois and European settlers cohabited. Though focused on spatial geography and settlement on the edges of Iroquoian and European territory, Preston also emphasizes the importance of local, faceto-face interactions in shaping frontier relationships. David L. Preston, The Texture of Contact: European and
} 
and practice of their members, and outward, shaping interactions with outsiders who were beyond the bounds of community. Recent scholars in Native American history have emphasized the importance of town and local identity as a component of the Native American worldview. Joshua Piker's analysis of the Creek town of Okfuskee makes a compelling case for the importance of the local experience for natives at the level of town and village. ${ }^{10}$ Tyler Boulware's deconstruction of the Cherokee in the eighteenth century places town at the forefront of identity in demonstrating the fractures between various groups that were all ostensibly "Cherokee."11 The primary area of study for these scholars has been in regions where natives maintained political autonomy and even dictated the terms of interaction, eschewing more complicated settings such as New England. The principal reason for this is that historians who approach a Native history in this region must contend with the growth of puritan power and the corresponding shrinkage of Native control in the region, which adds another layer of complexity to such a study. Nevertheless, it is worthwhile to consider native communities in this region from contact through colonization in order to better understand this important resource for survival and cultural preservation. For Native Americans behind the crest of European settlement, it is equally worthwhile to explore strategies of autonomy and ethnogenesis as they sought to forge a place in an increasingly European world.

Historians should also consider the importance of community, along with its health and wellbeing for puritans, as the New England town and church were fundamental loci for the puritan experience. They similarly derived particular importance from the morality and

Indian Settler Communities on the Frontiers of Iroquoia, 1667-1783 (Lincoln: University of Nebraska Press, 2009), $1-4$.

${ }^{10}$ Joshua Piker, Okfuskee: A Creek Indian Town in Colonial America (Cambridge: Harvard University Press, 2004), $1,8-10$.

${ }^{11}$ Tyler Boulware, Deconstructing the Cherokee Nation: Town, Region, and Nation among Eighteenth-Century Cherokees (Gainesville: University Press of Florida, 2011), 2-4. 
religiosity of these communities, as individual members and the town together covenanted to serve the Christian God and practice good works that might give them personal assurance of their election. These "visible saints" lived in close-knit towns where the puritan church was arguably the centerpiece of daily life. With the 1636 law that redefined freemanship as a status for men who had passed their religious confessional in the local Congregationalist church, the colony linked political participation with spiritual election, making local religiosity a crucial component for voting and office-holding in the wider colony. ${ }^{12}$ Puritans also thought in terms of covenant theology and conceptualized the body of saints, living in a physical New England town, as operating under a contractual agreement with their stern creator. It was only by upholding their end of the covenant that God would bless their society and bring about the reformation of English churches. In his devotional journal, puritan minister Thomas Shepard wrote on November 4, 1641: "In the beginning of this day I began to consider whether all the country did not fare the worse for my sins, and I saw it was so, and this was an humbling thought to me. And I thought if everyone in particular thought so and was humbled, it would do well."13 Shepard clearly linked individual behavior with community wellbeing. As they journeyed across the Atlantic to the Massachusetts Bay Colony, puritans had the first real opportunity to establish their ideal communities in a concrete setting. ${ }^{14}$ Furthermore, they did so knowing that they would be settling in a land peopled by natives who were "uncivilized heathens" at best, or demonic agents of the devil at worst. It is worthwhile then to consider puritan ideas of community, particularly the religious community they sought to realize in North America, as a crucial factor that shaped interactions with Native Americans from contact onward.

\footnotetext{
${ }^{12}$ Edmund S. Morgan, Visible Saints: The History of a Puritan Idea (Ithaca: Cornell University Press, 1987), 1-4, 104-05.

13 Thomas Shepard, God's Plot: Puritan Spirituality in Thomas Shepard's Cambridge, Michael McGiffert, ed. (Amherst: University of Massachusetts Press, 1994), 102.

${ }^{14}$ Morgan, Visible Saints, 80-81.
} 
This chapter begins with an analysis of Native American social organization prior to European contact and colonization to assess the importance of community as a component to Native American identity, as well as the role of religious belief and practice as forces of cohesion within such communities. Native beliefs are juxtaposed with puritan religious ideals, as laid out in ministerial sermons, pamphlets, and theological treatises to underscore the religious nature of puritan community and the importance that they placed in establishing new settlements in North America. What follows is an examination of early contact history and the relations between puritans and various Native American groups to demonstrate the nature of early interactions. It then concludes by exploring the ways in which both Native Americans and puritans faced rising tensions in the 1630 s and understood them in particularly religious ways, creating tension between their communities. For Native Americans, the biggest disruptions that they faced included warfare and disease. Puritans faced threats from within in debates over Congregationalist or Presbyterian models of church governance, warfare with the Pequot, and the Antinomian controversy. Thus, both groups entered the 1640 s with concerns for community health and wellbeing and heightened sensitivities towards their respective "other." The decision by some Native Americans to enter into a closer alliance with John Eliot, Thomas Mayhew, and other English missionaries to form "Praying Towns" after 1648 must also be analyzed through this lens of communal covenant and the importance of interconnection.

\section{Native American Community Organization and Religion: An Anthropological Perspective}

The lacunae of sixteenth and seventeenth-century written records expressing a Native understanding of religious beliefs and practices represents a significant problem for analyzing and understanding Native American religion prior to contact and in the early years of 
colonization. The most common sources that provide a glimpse at native beliefs are those of the early explorers and settlers, whose religious and cultural biases, along with the language gap between English and Algonquian, makes them incomplete witnesses to a truly native perspective. ${ }^{15}$ Oral myths and legends as recorded by later generations and ethnographers are helpful insofar as we recognize the changes and permutations that came with sustained interaction between Algonquian religious ideas and Christian ideas. ${ }^{16}$ Anthropological methods such as comparative ethnology and the reading of archaeological artifacts and grave goods represent the best supplements to these other sources. ${ }^{17}$ The purpose of this section is twofold: first, it seeks to explain the general concepts and structures of Algonquian religious beliefs and practices. Second, it demonstrates the powerful interconnections between religious beliefs and Native American society and polity. Spiritual forces, particularly manitou and cosmological connections between the physical and immaterial world, shaped social, political, and gendered interactions. Understanding the connections between religious forces and these elements, which

\footnotetext{
${ }^{15}$ Gordon Sayre observes that the earliest travel narratives and ethnographies utilized within this chapter maintain a "hybrid form" which "contained the epistemological contradictions" facing European writers: "it organized partial knowledge so as to make it appear complete, and to enable colonials to impose a sense of order and control over the land and the Indians." Gordon M. Sayre, Les Sauvages Américains: Representations of Native Americans in French and English Colonial Literature (Chapel Hill: University of North Carolina Press, 1997), 79.

${ }^{16}$ Anthony Wonderley argues that Iroquoian and Algonquian-speaking groups have the richest and most extant record of folkloric and mythic tradition. He also draws on the work of Claude Lévi-Strauss to argue that the structural similarities in many of these stories, despite their interpolations and differences, are indicative of shared cultural values. In his conclusion, Wonderely also makes a compelling case that oral narratives are an important source of religious ideas as well as representative of their movement across considerable distances, despite the ambiguity inherent in oral lore. Anthony Wonderley, At the Font of the Marvelous: Exploring Oral Narratives and Mythic Imagery of the Iroquois and Their Neighbors (Syracuse: Syracuse University Press, 2009), xiii, xxiii, 15052. Similarly, William S. Simmons argues that many oral narratives are shaped by native responses to Christianity, which he contends were inherently steeped in conflict. As such, he delineates four themes that shaped Native American legends about Christianity: religious conflict stemmed from divergent cultures, the ultimate triumph of Christianity, the importance of miraculous providence and signs, and the notion that natives already possessed some Christian beliefs and rituals prior to contact. William S. Simmons, Spirit of the New England Tribes: Indian History and Folklore (Hanover: University Press of New England, 1986), 73.

${ }^{17}$ In The Interpretation of Culture, Clifford Geertz stresses the notion of searching for meaning as the essential task of ethnography, highlighting the necessarily public nature of culture and meaning. As such, reading early ethnographic descriptions of Native Americans in New England is essentially a task of interpretation as historians struggle to understand the nature of native beliefs and practices in the face of English biases in observation and notation. Clifford Geertz, The Interpretation of Cultures: Selected Essays by Clifford Geertz (New York: Basic Books, Inc., 1973), 5-13.
} 
add up to a robust community in Algonquian-speaking Native America, is a crucial first step in evaluating how these communities changed and adapted to confront colonialism, warfare, disease, and the task of rebuilding.

Algonquians imagined a world shaped by and imbued with powerful forces, or manitou, which animated or resided in the smallest, most unique or most dangerous objects. Roger Williams recorded that "at the apprehension of any Excellency in Men, Women, Birds, Beasts, Fish, \&c. to cry out Manittoo, that is, it is a God, as thus if they see one man excel others in Wisdome, Valour, strength, Activity \&c. they cry out Manittoo A God."18 The possession of powerful manitou marked the many wondrous objects, animals, and people in the physical world. These forces are clearly at work in their origin stories, as the most powerful manitou appear to have had anthropomorphic properties as beings that interacted with the world and the people within it. In this vein, Williams also noted that the Narragansett believed fire to be an animate manitou with a will of its own, for a spark and flame could save a person in the winter cold and cook food for them, yet it could also become angry and burn down a home or the surrounding fields and woods. ${ }^{19}$ The Narragansett thus ascribed symbolic meanings and potent signs to natural calamities such as storms, earthquakes, and sickness. ${ }^{20}$ The world was a mysterious place, animated by the spiritual power of manitou, and Algonquians incorporated new discoveries and power within this flexible spiritual framework. The arrival of Englishmen brought new and strange technology and diseases; from an Algonquian perspective it stood to reason that they derived their strength from different gods, with different manitou. ${ }^{21}$

\footnotetext{
${ }^{18}$ Williams, A Key Into the Language, 150.

${ }^{19}$ Ibid., 150.

${ }^{20}$ Simmons, Spirit of the New England Tribes, 37.

${ }^{21}$ Neal Salisbury, Manitou and Providence: Indians, Europeans, and the Making of New England, 1500-1643 (Oxford: Oxford University Press, 1984), 39. Roger Williams noted in his section on Native religion that the people he spoke with surmised that they and the English were created by their own corresponding gods. Williams, A Key Into the Language, 147-48. Though it is possible to differentiate differences in veneration between upper New
} 
Contact with these powerful spirits shaped daily life and efforts to harness their efficacy while appeasing them or thwarting any malevolence that might come from fickle spirits like Abbomocho. Certain creatures in the world, such as beavers and thunderbirds, could aid humans because they were the earthly emissaries of guardian spirits. ${ }^{22}$ John Josselyn, an early visitor to the New England colonies, recorded an incident while he was aboard ship where a pair of natives (most likely Nipmucs or Massachusetts) dissuaded the English from shooting at a serpent coiled on a rock at Cape Ann because "if he were not kill'd out-right, they would be all in danger of their lives." The implication was that the serpent was associated with powerful manitou, most likely Abbomocho. ${ }^{23}$ In Wonder-Working Providence of Scions Saviour in New England (1654), Edward Johnson, one of the early planters of the Puritan colony and founder of Woburn, noted that a powwow "was seen as is reported to cure a Squaw that was dangerously sick, by taking a snakes skin and winding it around her arm the which soon became a living snake crawling round about her armes and body." When a person survived this treatment, they cried "much winnit Abbamocho," in thanks for his intervention. ${ }^{24}$ Similarly, Josselyn was told that "if they can see a Tree-Buck walking upon the branches of an Oake when they go out in a morning to hunt, they shall have good luck that day." ${ }^{25}$ Anthropologists have also noted that archaeological remains from the region are often marked with illustrations of native animals in an effort to harness their

\footnotetext{
England spiritual devotion and that of the more agriculturalist lower New England tribes, the dichotomy between an ultimately powerful spirit and its chief rival - a trickster sprit responsible for much of life's misery that must be thwarted by temporal practices - appears to be the norm. James Axtell, The Invasion Within: The Contest of Cultures in Colonial North America (Oxford: Oxford University Press, 1985), 16.

${ }^{22}$ Bragdon, Native People of Southern New England, 186.

${ }^{23}$ Josselyn, Account of Two Voyages, 22.

${ }^{24}$ Edward Johnson, Wonder-Working Providence of Sions Saviour in New-England (1654) and Good News From New England (1648) (New York: Scholars' Facsimiles \& Reprints, 1974), 225-26. Johnson also served as a militia captain, deputy to the General Court, and town clerk. Ibid., v.

25 Josselyn, Account of Two Voyages, 51.
} 
power in the physical world. ${ }^{26}$ Both individuals and the community at large sought these forces and the power that they could have over natural forces and other people. Shamans, or "powwows," as many native communities in this region called them, acquired access to the most powerful manitou and were both revered and feared by their neighbors for their abilities to heal and curse.

Everywhere natives traveled, they passed through a world alive with manitou's power.

Kathleen J. Bragdon argues that a common belief held by many Algonquian-speaking people that a "Cosmic Axis," linked the varied layers of the universe: an upper sky or spirit world, the earth or middle world, and the underworld or underwater world. Certain geographic locations and physical spaces were thus powerful links between the earth and metaphysical places. ${ }^{27}$ Edward Johnson wrote that Indians frequently spoke of apparitions (which he attributed to the Devil), occurring "in the most hideous woods and swamps," though "sometimes he hath come into their wigwams, and carried away divers of them alive. ${ }^{28}$ In the section of A Key into the Language of North America on native religious beliefs and practices, Roger Williams observed that the Narragansett saw manitou "filling all things, all places." 29 According to John Josselyn, one Massachusett man was terrified in a corn field when he saw an apparition of two spirits in the shape of Mohawks, and another time when three natives cried out for fear of death when they saw "Cheepie was gone over the field gliding in the Air with a long rope hanging from one of

\footnotetext{
${ }^{26}$ Bragdon, Native People of Southern New England, 185-87. Wonderley stresses that decorative goods are rare archaeological finds, but that religious meanings, as preserved in myths and folklore, should be considered when interpreting their characters and symbols. Wonderley, At the Font of the Marvelous, 115.

${ }^{27}$ Bragdon, Native People of Southern New England, 185,191-92.

${ }^{28}$ Johnson, Wonder-Working Providence, 226. Johnson continues this story, or possibly another, reporting of "a very terrible beast for shape and bigness, that came into a wigwam toward the North-east parts, remote from any English plantations, and took away six men at a time, who were never seen afterward." It is possible that this was a Windigo story, which Wonderley notes was widespread among Algonquian-speaking people. Wonderley, At the Font of the Marvelous, 72.

${ }^{29}$ Williams, A Key into the Language, 151.
} 
his legs. ${ }^{" 30}$ Given the strong association between snakes and Abbomocho, or Chepi, it is reasonable to assume that when William Wood noted that "up into the Countrey westward from the plantations is a high hill, which is called rattlesnake hill, where there is great store of these poysonous creatures," he had received this knowledge from indigenous informants who believed the hill to be a sacred space associated with manitou. ${ }^{31}$ Thomas Morton recorded that it was custom for the Pokanokets to "ceremoniously and carefully" bury their dead and abandon that place, because they have no desire the place should put them in minde of mortality." ${ }^{32}$ Equally plausible from an anthropological standpoint is the link between burial grounds, the souls of the dead, and passage into other realms. Numerous thresholds existed throughout the world where connections between the upper, middle, and lower realms existed through intermediaries or the entrance of powerful manitou into the physical plane. ${ }^{33}$ Individuals and entire communities were mindful of manitou's presence and power in the world, and these cosmological beliefs also served to shape community relations and interactions at the societal and political levels.

The Pawtucket, Massachusett, Nipmuc, Narragansett, Mohegan, Pequot, and other groups that made up New England's population on the eve of colonization share a series of general characteristics when it comes to societal organization. Most practiced a mixture of farming during the summer, growing maize, beans, and squash, in addition to fishing and hunting. As such, they tended to remain in the same general location throughout the winter in contrast to the Abenaki of Maine or the Montagnais in New France. Good harvests relied on harnessing the efficacy of manitou along with rituals to appease spirits like Cautantowwit and ensure

\footnotetext{
${ }^{30}$ Josselyn, Account of Two Voyages, 104.

${ }^{31}$ Wood, New Englands Prospect, 51.

${ }^{32}$ Morton, New English Canaan, 133.

${ }^{33}$ Bragdon, Native People of Southern New England, 192-93.
} 
agricultural abundance. ${ }^{34}$ During the harsher winter months, some communities broke into smaller family units and relied primarily on hunting while living off of stored agricultural reserves from the fall harvest. ${ }^{35}$ Nevertheless, most polities had clear understandings of their territorial extent and relations, both good and bad, with neighboring groups. Algonquians within the region also developed substantial trade networks which brought them into contact with farflung groups and gave access to a variety of goods, most often specialty items prized for their symbolic or ritual power. ${ }^{36}$ Trading was frequently a community activity, involving the transport of goods as well as negotiations, and Roger Williams noted that "amongst themselves they trade their Corne, skins, Coates, Venison, Fish, \&c. and sometimes come ten or twenty in a Company to trade amongst the English. ${ }^{137}$ Similarly, hunting was a geographically expansive community activity, where the Narragansett pursued deer "in twentie, fortie, fiftie, yea, two or three hundred in a company, (as I have seene) when they drive the woods before them." When trapping, Williams also observed that after harvest time they would build small hunting houses of bark and take with them their wives and children to capture game. ${ }^{38}$

\footnotetext{
${ }^{34}$ Salisbury, Manitou and Providence, 36. Linford D. Fisher writes that "pervading all of Indian life was an emphasis on the community. The family served as the most basic block of social organization, although Indian families were built - and dismantled - in ways that defied European family logic." I would add that the religious framework established above in this chapter highlights the important role that religious belief and practices played in animating such communities. Linford D. Fisher, The Indian Great Awakening: Religion and the Shaping of Native Cultures in Early America (Oxford: Oxford University Press, 2012), 21.

${ }^{35}$ Bragdon places the growing importance of maize in the Massachusetts Bay region to around $1300 \mathrm{CE}$, with a growing emphasis on territoriality and fixity in settlement patterns. Bragdon, Native People of Southern New England, 80-85. Salisbury asserts that by the seventeenth century agriculture had replaced hunting as the primary source of food. Salisbury, Manitou and Providence, 31. Thomas Morton noted that natives "use not to winter and summer in one place, for that would be a reason to make fuell scarse; but, after the manner of the gentry of Civilized natives, remoove for their pleasures; some times to their hunting places, where they remaine keeping good hospitality for that season; and sometimes to their fishing places, where they abide for that season likewise." Morton, New English Canaan, 138.

${ }^{36}$ Bragdon, Native People of Southern New England, 96. The most common item of trade was wampum, consisting of both black and white varieties. The importance and ubiquity of this item of trade led observers such as Roger Williams to conclude that this was a form of currency for the Narragansett. Williams, A Key into the Language, 173. ${ }^{37}$ Ibid., 163.

${ }^{38}$ Ibid., 188-89.
} 
The separate tasks in which men and women both engaged ensured that they encountered different spiritual forces in the world and enjoyed times of gender-segregated community. Since women spent much of their time growing agricultural products and processing them, it is likely that they held a special relationship with Cautantowwit. "Their women constantly beat all their corne with hand: they plant it, dresse it," gather it, barne it, beat it, and take as much paines as any people in the world, which labour is questionlesse one cause of their extraordinary ease of childbirth," wrote Roger Williams, and "the Women set or plant, weede, and hill, and gather and barne all the corne, and Fruites of the field: Yet sometimes the man himselfe, (either out of love to his Wife, or care for his Children, or being an old man) will help the Woman which (by the custome of the Countrey,) they are not bound to." Breaking ground on a new field for crops was also a community affair that would consume all of the surrounding families and friends.

Williams so admired this aspect of Narragansett society that he wrote: "With friendly joyning they breake up their fields, build their Forts, hunt the Woods, stop and kill fish in the Rivers, it being true with them as in all the World in the Affaires of Earth or Heaven : By concord little things grow great, by discord the greatest come to nothing." ${ }^{39}$ Menstruation was also special time when native women served as conduits for mystical power, so much so that the Narragansett sequestered them in special dwellings for four or five days during which interaction with men was strictly forbidden. ${ }^{40}$

Males experienced gender-segregated camaraderie through hunting and their own rituals, but the principal arena of masculine socialization was warfare. This was a particular activity that "was key to the performance of manhood as well as an opportunity to enlarge or protect

\footnotetext{
${ }^{39}$ Ibid., 65, 123. Bragdon stresses that it is difficult to determine social status for women in native New England, in part because the sources that directly address women written by European observers are scant. Bragdon, Native People in Southern New England, 176-78.

${ }^{40}$ Ibid., 24.Williams later reiterates that this was a common practice "in all parts of the Countrey." Ibid., 60.
} 
territorial claims, because manhood and political and economic autonomy were inseparable."41 Though women occasionally joined in hunting and defended themselves during battles, warfare was a primarily male activity. Male warriors taunted their enemies and prided themselves on darting through the thick of battle and taking their enemies in hand to hand combat, according to Roger Williams. ${ }^{42}$ Some groups would defend themselves in palisaded forts constructed of timber and earthworks for protection, firing a hail of arrows on enemies when they ventured close enough to hit. William Wood also noted that it was customary during warfare to paint the faces of warriors various shades and patterns of red, black, and white - colors which were symbolically associated with various manitou, including Abbomocho. ${ }^{43}$ Bravery in battle, along with the ability of a sachem to defend and lead his people successfully in warfare, were values held by the community at large. Men and women also came together to ritually torture, adopt, or execute captives taken in battle. Ann M. Little notes that "meeting death as a man and proving oneself worthy of the honor of ritual execution was more revealing of an Indian man's true worth than his performance in battle." 44 Subjected to gruesome methods of torture that included severe burning and mutilation, captured warriors relied on the strength their manitou conveyed to them especially in these agonizing moments in order to die a good warrior's death. ${ }^{45}$

Finally, religious belief and practice frequently intersected with polity leadership in the interplay between sachem and powwow within the community. As leaders, sachems relied on a rule shaped by their ability to command and achieve social consensus and approval, though some

\footnotetext{
${ }^{41}$ Ann M. Little, Abraham in Arms: War and Gender in Colonial New England (Philadelphia: University of Pennsylvania Press, 2007), 15

${ }^{42}$ Williams, A Key into the Language, 202, 204.

${ }^{43}$ Wood, New Englands Prospect, 94-95.

${ }^{44}$ Little, Abraham in Arms, 29, 34-35.

${ }^{45}$ Ibid., 72-73. The most extensive monograph on the parallels between native and European deathways during the colonial period is Erik R. Seeman's The Huron-Wendat Feast of the Dead. Erik R. Seeman, The Huron-Wendat Feast of the Dead: Indian-European Encounters in Early North America (Baltimore: John Hopkins University Press, 2011).
} 
sachems passed the mantle of leadership hereditarily through the male line. Wood noted that sachems were "so either feared or beloved, that halfe their Subjects estate is at their Service, and their persons at his command; by which command he is better knowne than by any thing else." Oratory skill also promoted a sachem within the community, as did quick and decisive action in quelling factionalism or challenges to the sachem seat. ${ }^{46}$ Thomas Morton noted that the youth within a community tended to obey the word of their elders and the sachem, though native councils always gave them the opportunity voice their opinions. ${ }^{47}$ Some communities maintained two sachems, most likely for warfare and community affairs, as Roger Williams noted that the Narragansett had two leaders, Miantonomo and Canonicus. Williams noted the harmony that existed between these two leaders in particular, and the importance that they placed on community consensus in decision-making, as "they will not conclude of ought that concernes all, either Lawes, or Subsides, or warres, unto which the people are averse, and by gentle perswasion cannot be brought." ${ }^{48}$ In the intersection of leadership, harvest, trade, and warfare, a sachem drew on powerful spiritual forces that flowed throughout the natural world. Some sachems and their emissaries claimed special relationships with particular manitou, especially Abbomocho. ${ }^{49}$ Bragdon also suggests that sachems held great symbolic and ritual importance as a representation of the health and wellbeing of the community at large, and as such presided over several religious rituals in addition to redistributing trade goods, settling community disputes, and conducting diplomacy with outsiders. ${ }^{50}$ The fear that Wood described could rightly been said to derive from the powerful role and position of the sachem within the community and as a conduit

\footnotetext{
${ }^{46}$ Wood, New England's Prospect, 89-90.

${ }^{47}$ Morton, New English Canaan, 148-49.

${ }^{48}$ Williams, A Key into the Language, 163-64.

${ }^{49}$ Bragdon, Native People of Southern New England, 143. Bragdon notes a particular leader described by Edward Winslow as the pniesesok, who acted on the sachem's behalf and claimed this relationship. Neal Salisbury also notes that some natives, such as Membertou of the Micmac and Passaconoway of the Pennacook, blurred the boundary between sachem and powwow by "assuming shamanistic powers." Salisbury, Manitou and Providence, 43. ${ }^{50}$ Ibid., 153-54.
} 
for manitou. The sachem and the powwows met any gripping calamities that befell the community first and foremost, guiding outward and inward interactions between people and manitou. Communities as a whole would thus interpret sachem and powwow failures as a loss of manitou and authority in leadership.

Powwows served as both political and military advisers to the sachems because of the powerful connection they maintained with manitou, in addition to their roles as healers and interpreters of signs and dreams within the community. Morton described Passaconoway, a Pennacook sachem and powwow, as a powerful conjurer who demonstrated his spiritual strength through a series of magical feats that awed members of his community. He noted that "it is thought a very impious matter for any man to derogate from the words of these Powahs. In so much as hee that should slight them, is thought to commit a crime no lesse hainous amongst them as sacriledge is with us." 51 Powwows served the ever-important role of town and community healers, conducting elaborate rituals around the afflicted, who often lay prone on the ground, utilizing a variety of charms and objects imbued with manitou to bring about a successful restoration of health. Josselyn noted that after a positive ritual, certain goods, including bows and arrows, wampum, and beaver skins, would be gathered and taken to a great rock pit to the east where they would be thrown, inadvertently demonstrating the link between ritual practice and manitou with sacred sites and objects. ${ }^{52}$ Though powwows were the most efficacious bearers of healing manitou, the community was also involved in these rituals, frequently gathering together to join in the ceremony and appeal to manitou for healing. ${ }^{53}$ James Axtell notes that the personal power that powwows held within native communities was doubleedged, and that their ability to manipulate the physical world and bewitch their enemies caused

\footnotetext{
${ }^{51}$ Morton, New English Canaan, 151.

52 Josselyn, Two Voyages to New England, 104-05.

${ }^{53}$ Williams, A Key into the Language, 213.
} 
their neighbors to fear them equally. ${ }^{54}$ Within the community, powwows served an essential role in shaping and directing the forces at work in the world for the benefit of their companions, in addition to an interpretive role in understanding dreams and wondrous signs that could benefit or destroy individuals and families. Powwows and sachems together evaluated outsiders, and the manitou that they possessed, working to understand their intent and nature. Equally important was decision-making on how best to protect the community and leverage opportunities to their advantage.

The arrival of Europeans posed an interesting quandary to the Massachusett and Narragansett who first encountered them. Not only did they speak a different language, have strange physical appearances, and bring with them new and suspicious objects, such as guns, but they also carried different religious ideas and understandings of the cosmos. At the microbial level, they carried with them diseases that would pose a devastating challenge for communities and their metaphysical beliefs. Community as a religio-social concept was equally important to puritans, especially when we consider the nature of their colonial project in Massachusetts Bay in terms of covenant theology and efforts to reform the Laudian church in England. They also held specific notions regarding community health and the linkages between political and religious leaders and the community at large. For both groups, powerful spiritual forces mediated and shaped their lived experiences and attitudes towards outsiders and would in turn affect how they related to each other.

\section{Puritan Covenant Theology as a Cultural Force in New England}

Discussions of puritan relations with Native Americans in New England have yet to adequately ground these interactions between communities that often appear disparate in a

\footnotetext{
${ }^{54}$ Axtell, The Invasion Within, 17.
} 
theological understanding from the perspective of the puritans. Conceptualizations of

Calvinism's severity often approach caricature rather than a nuanced and sensitive consideration of this strain of theology as a potent cultural force that shaped puritan action in complicated ways. ${ }^{55}$ While we can no longer embrace Perry Miller's certainty in the monolithic nature of the "Puritan mind" in New England given the complexity of individual experiences and beliefs, we can point to the larger concepts and axioms at work within puritan theology as generalized religious forces that shaped their thoughts and actions. ${ }^{56}$ These key beliefs provided the template by which puritans understood the cosmological and teleological nature of the earth and its inhabitants, including Native Americans. Religious belief also shaped the nature of both church government and the covenant theology that formed the foundation of the New England village as the first generation of settlers attempted to put into practice their theological convictions. At the same time, connections between New and Old England continued throughout the colonial period and are important to consider in light of the image puritans hoped to convey to Europe regarding their successes, especially in terms of interactions with Native Americans. Therefore, an exploration of puritan beliefs about community and religion's role in ordering and shaping

\footnotetext{
${ }^{55}$ Ibid., 131-136, 139-146. Most evaluations of Puritan theology seem to focus on internal issues of communal strife for the Puritans, such as the Antinomian controversy, Roger Williams' banishment, and witch trials at Salem. Applying a similar focus on the ways Puritan theology guided interactions with native communities represents a key historiographic advancement made by this chapter.

${ }^{56}$ One of the best collections of older essays representing the historiographic shifts in thought on New England Puritanism is David D. Hall's Puritanism in Seventeenth-Century Massachusetts. David D. Hall, ed. Puritanism in Seventeenth-Century Massachusetts (New York: Hold Rinehart and Winston, 1968). Francis J. Bremer has also noted that the reality of early colonization and the numerous disagreements between Puritan readers betrays the reality of divergent opinions regarding faith and governance. Francis J. Bremer The Puritan Experiment: New England Society from Bradford to Edwards (New York: St. Martin's Press, 1976), 18. Also contested is the notion of declension in later generations of Puritans with the Half-Way Covenant, which seemingly casts second and third generation colonists as inferior to the founding generation in religious commitment. Robert G. Pope argues that the rejection of the filiopietist position simply means acknowledging that Puritans "adapted and changed to fit the environment" shortly after Winthrop and the other founding colonists disembarked from the Arbella. He also argues that difference in experiences that the founding generation, born into controversy during the Laudian persecution, and their children, born into relative stability in New England, ensured that the second generation became less likely to undergo "soul-shattering conversion." Robert G. Pope, "New England versus the New England Mind: The Myth of Declension," Journal of Social History 3 (1969): 98, 107.
} 
interactions within and without is crucial to a consideration of interactions with Native Americans in a colonial context.

The puritans who traveled to New England to build ideal communities maintained relatively high levels of literacy and education in comparison to other sites of colonization, with many university graduates and men like John Winthrop, Harry Vane, and Richard Saltonstall, who attended universities but never matriculated. Similarly, these men and women were wellread and took with them substantial libraries to their new settlements where they frequently loaned books to each other to supplement their reading habits. ${ }^{57}$ Puritans gave theological primacy to the Bible, especially in its 1599 Geneva form or a subsequent edition, so it is no surprise that colonial libraries and homes frequently included this text. That said, puritans also read widely within Protestant circles, taking with them copies of Calvin and Luther as well as traditional Catholic luminaries such as Augustine and Aquinas. ${ }^{58}$ English theologians William Ames, John Preston, and Richard Sibbes played important roles in defining and articulating puritan theology, as did Thomas Shepard, Peter Bulkeley, John Cotton, and other New England settlers and ministers who penned theological treatises, promotional tracts, and defenses of the "New England Way." 59 Among English puritan theologians, William Ames's Marrow of Theology represents the most widely-read and influential distillation of puritan thought in the form of a simple Latin compendium. It quickly became a popular and essential text for students at puritan schools in Europe and New England. John Dykstra Eusden offers the most authoritative explanation of his influence in colonial New England: "his covenant theology,

\footnotetext{
57 Thomas Goddard Wright, Literary Culture in Early New England 1620-1730 (New York: Russell \& Russell, 1966), 15-17, 61. Wright also maintains on page 61 that the Puritan colonists "constantly added new books, and supplemented their own libraries by borrowing freely from their neighbors near and remote, they were not without the means of culture and had access to a moderate amount of real literature."

58 Bremer, The Puritan Experiment, 18-19.

${ }^{59}$ Samuel Eliot Morison, The Intellectual Life of Colonial New England, $2^{\text {nd }}$ ed. (New York: New York University Press, 1956), 160-61. In Visible Saints, Edmund S. Morgan also notes that Paul Baynes, William Bradshaw, Arthur Hildersam, and Robert Parker were influential sources of early Puritan theology. Morgan, Visible Saints, 65.
} 
church polity, Ramist thought, understanding of the Scriptures, and conception of faith and religious experience were accepted as canonical."60 Thus, a brief examination of ideas from Ames' work serves to outline points of puritan consensus in theology.

The Marrow of Theology contains a number of pithy statements that shaped puritan understandings of community and relationships between individuals and God. Ames contends that faith "is resting of the heart of God" and depends on the authority of God or divine revelation, implying that faith is inseparable from a personal experience, which would shape the confessional nature of church membership in New England. ${ }^{61}$ God created the world itself, ex nihilo, and his providence shaped the existence of all things "in accordance with the counsel of his will," creating mankind to live in community with one another. The consequences of Adam and Eve's fall in Eden promulgated an original sin that tainted all of their progeny, and only Jesus's sacrificial death could atone for this cosmic imbalance. However, the Devil marred the world with his machinations and temptations freely before Jesus finally returned to usher in his millennial kingdom. ${ }^{62}$ God's omniscience and power also ensured that "predestination has existed from eternity" and that no human action could shape this fate, which "depends upon no cause, reason, or outward condition, but proceeds purely from the will of him who predestines." ${ }^{\prime 63}$ The proper church, which was the physical manifestation of God's will and action on Earth, was to be made up of elect individuals who covenant to follow God's will, making

\footnotetext{
60 John Dykstra Eusden, trans. "Introduction," in The Marrow of Theology: William Ames (1576-1633) (Grand Rapids: Baker Books, 1997), 1-3, 65. Eusden contends that Ames was not completely orthodox, especially regarding his views on preparation for grace in the relationship between man and God, and that he was probably the most sensitive to oppositional viewpoints within Puritanism despite his overall orthodoxy. Ibid., 7.

61 Ibid., 80-81.

${ }^{62}$ Ibid., 100-101, 107, 113-137. This cosmological struggle was shaped by the activity of both God and Satan in the real world, which David D. Hall explores in Worlds of Wonder, Days of Judgment. Hall contends that "the people of seventeenth-century New England lived in an enchanted universe. Theirs was a world of wonders," which looked markedly similar to Native American conceptions of the cosmos, which emphasized the efficacy of manitou in shaping the real world and blurring the boundaries with the immaterial. David D. Hall, Worlds of Wonder, Days of Judgment: Popular Religious Belief in Early New England (Cambridge: Harvard University Press, 1989 ), 71. ${ }^{63}$ Ibid., 152-53.
} 
visible the proof that they have been predestined to salvation through their behavior and the "communion of the saints." The creation of a puritan church was a mystical manifestation of the holy in a tainted world: "a certain spiritual polity" that was set apart from those who were not among the elect. ${ }^{64}$ Puritans who settled in New England drew extensively on Ames' thought and the Marrow when they established their settlements, especially in their conceptualizations of community and the relationship between individuals, colonial government and the church covenant.

New England represented a tabula rasa on which to etch these lofty community ideals, free from the snares of English society and the Laudian church. This naturally raises questions regarding the place of Native Americans and puritan conceptions of their communities existing within an initial sphere of native influence. In a recent monograph David D. Hall argues that this unique environment made the puritans the most ambitious and experimental reformers of their day, despite their insistence on preserving order within their communities and the basic hierarchical structures they believed to be natural and God-ordained. ${ }^{65}$ Puritans thus adopted a middle path that reworked church governance, emphasizing voluntary membership and lay consent, while maintaining undemocratic elements in society at large by linking freeman status

\footnotetext{
${ }^{64}$ Ibid., 175, 177, 180.

${ }^{65}$ David D. Hall, A Reforming People: Puritanism and the Transformation of Public Life in New England (New York: Alfred A. Knopf, 2011), xi-xiii, 3. Hall's insight into Puritan society also goes against conventional wisdom which holds the Puritans to be conservatively orthodox and resistant to change. Demonstrations of undemocratic elements of Puritan society have also been made by Joshua Miller and Scott Michaelsen to refute the notion that American democracy is rooted in the New England experience, through comparisons of Puritan government with modern liberalism and an analysis of Winthrop's "Modell" Covenant in his Arbella speech, respectively. Joshua Miller, "Direct Democracy and the Puritan Theory of Membership," The Journal of Politics 53 (1991): 57-74; Scott Michaelsen, "John Winthrop's 'Modell' Covenant and the Company Way," Early American Literature 27 (1992): 85-100. The notion of the New England village as the ideal settlement was firmly established and reified by Romantics like Emerson and Thoreau in the eighteenth century, which emphasizes the impact of the New England colonial experience on subsequent generations and early American myth-making about the colonial past. Joseph S. Wood, "Build, Therefore, Your Own World': The New England Village as Settlement Ideal," Annals of the Association of American Geographers 81 (1991): 32-50.
} 
with church membership. ${ }^{66}$ In the Marrow Ames visualized "this polity [as] altogether

monarchical in respect to Christ as the king and the head. But in respect to the visible system of administration, it is of a mixed nature: partly aristocratic, so to speak, and partly democratic."

Puritan leaders expected communities to live in obedience to Christ, as well as his earthly leaders and ministers within the church. The concern for discipline and the failure of the Anglican Church to adequately carry out puritan reforms drove this spirit of experimentation and carried these reformers to North America. ${ }^{67}$ Ames also argues for equality among ministers in matters of church governance and their responsibility to tend to the spiritual wellbeing of their congregations. On disciplinary topics, he insisted that "the proper end of reproof is not excommunication (although by chance that sometimes may happen) but the prevention of it, so that the sinner by timely repentance may be kept in the church." 68 Puritan leaders expected and encouraged lay participation so long as it occurred within prescribed boundaries of propriety, a view codified by colonial leaders in 1648 with the Cambridge Platform, which mandated lay participation in day to day affairs of the church. They also expected the laity in colonial churches to practice "the communion of the saints" and serve their spiritual kin, which helped to render visible their election and forge a spiritual network of reciprocity within the community. ${ }^{69}$ At a conceptual level, a properly instituted church comprised of visible saints represented the best

\footnotetext{
${ }^{66}$ James F. Cooper, Jr., "Higher Law, Free Consent, Limited Authority: Church Government and Political Culture in Seventeenth-Century Massachusetts," The New England Quarterly 69 (1996): 201-03. Cooper, Jr. also emphasizes that lay dissent was among church members" "rights and responsibilities" to help maintain the health of the church body. Ibid., 213.

${ }^{67}$ Francis J. Bremer, Shaping New Englands: Puritan Clergymen in Seventeenth-Century England and New England (New York: Twayne Publishers, 1994), 58.

${ }^{68}$ Ames, The Marrow of Theology, 183, 190, 200. David C. Brown argues that excommunication was "wholly derivative" from age-old Catholic practices that Puritans appropriated as a power reserved to the church body. He also argues that the shift to civil punishment for crimes solved the jurisdictional problem Puritans faced in New England, as only church members could be punished by the church body. David C. Brown, "The Keys of the Kingdom: Excommunication in Colonial Massachusetts," The New England Quarterly 67 (1994): 532, 540. One final point worth mentioning on excommunication is that it was a punishment reserved for the worst offenders, as Puritans sought to reform or correct deviants before resorting to such a drastic punishment.

${ }^{69}$ Diane Willen, “'Communion of the Saints': Spiritual Reciprocity and the Godly Community in Early Modern England," Albion: A Quarterly Journal Concerned with British Studies 27 (1995): 19-20, 40.
} 
form of community possible in a world tainted by sin and ecclesiastical corruption, and interactions between the clergy and the laity would ensure that godliness and orthodox viewpoints reigned. God, who would actively intercede on behalf of his supplicants, blessed such a community and ensured its continuity while they kept their covenant.

The earliest debates within puritanism in the Old World, extending also to the New, revolved around the exact nature of this balance of power, and whether or not a Congregationalist or Presbyterian model of government was best. ${ }^{70}$ Some puritans were committed to forming autonomous communities and churches, while others argued that a network of churches shepherding each other through a series of synods would guard against heresy and better serve the members of individual churches. In his 1643 defense of the New England Way entitled Church Government and Church Covenant Discussed, Richard Mather stressed that "counsel or advice" was welcomed in assisting ministers of other churches "because Churches are as Sisters one to another," but in matters of actual governance, such as ordaining officers, such intervention was "not lawful nor convenient." lawful, as early churches in the Book of Acts relied on assistance from each other, but that the limits of synod power are "summarily laid downe by Doctor Ames... unto whom we do wholly consent in this matter." 72 John Cotton championed the independence of congregations, emphasizing "that no particular church standeth in subjection to another particular church" in his 1644 treatise The Keys of the Kingdom of Heaven, though he also proposed that the power of synods was limited and that the congregational model was better. ${ }^{73}$ Idealistic and millenarian

\footnotetext{
${ }^{70}$ Mark Garrett Longaker, "Puritan Sermon Method and Church Government: Solomon Stoddard's Rhetorical Legacy," The New England Quarterly 79 (2006): 439.

${ }^{71}$ Richard Mather, Church Government and Church Covenant Discussed (Weston Rhyn: Quinta Press, 2008), 4243.

${ }^{72}$ Ibid., 63-64.

${ }^{73}$ John Cotton, The Keys of the Kingdom of Heaven and The Way of Congregational Churches Cleared (Weston Rhyn: Quinta Press, 2008), 35, 42-47.
} 
minister John Eliot eventually hoped to unite Presbyterians with Congregationalists, as he advocated in The Communion of Churches. Other defenders of the "New England Way" also drew from their experiences in New England to hone their polemics, especially in the wake of challenges to their communities, discussed at length below. ${ }^{74}$ When the first puritan settlers established the Massachusetts Bay Colony, in relatively close proximity to their Separatist predecessors in Plymouth, these debates on church government and the relation to secular authority represented a significant source of tension, as did the practical issues of forming godly communities when opinions diverged.

Early puritans in New England were conscious not only of the importance that their venture represented, but in the connection that they maintained with fellow reformers back home. ${ }^{75}$ The histories written by John Winthrop, Edward Johnson, William Bradford, and Thomas Morton represent important sources not only on interactions with Native American communities, but also serve as representations of puritan perceptions of their communities along with the fruits born from the practical application of their theological commitments. Through these sources we can assess the earliest interactions between Native and English communities in New England, along with the groundwork laid for future encounters. In their colonial settlements puritans faced the difficulty of putting these ideas into practice far from England, and also the challenge of situating themselves amidst Native Americans. Native communities faced similar challenges in assessing how Europeans could fit within their own world, and how they might interact with people in their own towns and communities.

\footnotetext{
${ }^{74}$ Richard W. Cogley, "A Presbyterian in Congregationalist New England? The Case of John Eliot," The Journal of Presbyterian History 77 (1997): 71.

${ }^{75}$ In the introduction to The English Atlantic in an Age of Revolution, 1640-1661, Carla G. Pestana highlights the growing Atlantic scope of Winthrop's correspondence with extended friends and family, arguing that this Atlantic world grew especially and consolidated during the period of civil war and Interregnum in England. Carla G. Pestana, The English Atlantic in an Age of Revolution, 1640-1661 (Cambridge: Harvard University Press, 2004), 2-4.
} 


\section{Communities in Contact: Early New England History}

The Europeans who first settled at Plymouth in 1620 and Massachusetts Bay in 1630 relied on the growing body of writing regarding the Americas and the continent's indigenous inhabitants produced by European explorations from the previous century. For example, in Richard Hakluyt's account of the first voyage to Virginia the majority of the piece is an ethnographic description of the native inhabitants of Wingandacoa, as they called the land. ${ }^{76}$ When these settlers embarked on a transatlantic journey to establish new godly communities in North America, they did so knowing that they should expect to encounter native inhabitants and to settle amongst them. Thus, it is worthwhile to study closely the early histories of both Plymouth and Boston to analyze the nature of arrival and contact from both the indigenous and English perspectives. To accomplish such a task, close readings of diplomacy, trade, religious thought, and the nature of disagreements are instrumental in developing an understanding how groups interacted with and understood each other. Doing so highlights where community values or beliefs intersected and where Englishmen and Native Americans found themselves at odds.

When Bradford and the Plymouth settlers made landfall in 1620 at Cape Cod, the first Wampanoags that they encountered fled into the woods upon seeing the strange new arrivals in their land, so Bradford and his company set out again to find a new location, encountering still more Indians. It was not long before they had their first skirmish with indigenous neighbors in the month of December. After surviving the harsh winter and entering the early months of 1621, the Plymouth company's neighbors became increasingly bold, "skulking about them, and would sometimes show them selves aloofe of, but when any aproached near them, they would rune away," eventually working up the courage to steal tools absentmindedly left by settlers. Bradford

\footnotetext{
${ }^{76}$ Richard Hakluyt, Voyages and Discoveries: The Principal Navigations, Voyages, Traffiques and Discoveries of the English Nation, Jack Beeching, ed. (London: Penguin Books, 1985), 270-275
} 
considered it a providential occurrence, "a spetiall instrument sent of God for their good beyond their expectation," when an English-speaking native named Tisquantum, more commonly rendered "Squanto," committed himself to interpreting the English in their dealings with Samoset and Massasoit. ${ }^{77}$ In their first diplomatic meeting with Massasoit, the two communities agreed on the following:

1. That neither he nor any of his, should injurie or doe hurte to any of their people. 2. That if any of his did any hurte to anoy of theirs, he should send the offender, that they might punish him.

3. That if any thing were taken away from any of theirs, he should cause it to be restored; and they should doe the like to his.

4. If any did unjustly warr against him, they would aide him; if any did warr against them, he should aide them.

5. He should send to his neighbours confederats, to certifie them of this, that they might not wrong them, but might be likewise comprised in the conditions of peace.

6. That when ther men came to them, they should leave their bows \& arrows behind them. ${ }^{78}$

This initial agreement emphasized reciprocity in avoiding injury and allowing the English to punish native offenders as they saw fit, establishing a judicial edge in favor of the English. It promoted the avoidance of war between the two parties as well as a reciprocal agreement to aid each other in armed combat, and urged Massasoit to use his influence on their surrounding neighbors and allies to extend this peace agreement to them as well. Bradford and the Plymouth settlers thus relied on Wampanoag protection and information to help establish the colony. In August of that same year Bradford and the settlers faced their first real test of this alliance, as their ally Hobbamock warned Plymouth that a sachem named Corbitant in the town of Namassakett was plotting to kill both Tisquantum and the English. Fearing that "if they should suffer their freinds \& messengers thus to be wronged, they should have none would cleave unto them, or give them any intelligence, or doe them serviss afterwards; but next they would fall

\footnotetext{
${ }^{77}$ William Bradford, Of Plymouth Plantation, Harvey Wish, ed. (New York: Capricorn Books, 1962), 62-66, 72-73. ${ }^{78}$ Ibid., 73.
} 
upon them selves," Bradford and the colony leaders decided to send Captain Miles Standish along with fourteen armed men to beset the town and intimidate Corbitant and his people into returning Tisquantum. Afterwards, Bradford notes that "they had many gratulations from diverce sachims, and much firmer peace ... and this Corbitant him selfe used the mediation of Massassoyte to make his peace." ${ }^{" 79}$ Despite the energy and attention that the Leyden immigrants gave to building a new society in Plymouth - erecting buildings, plowing fields, and framing their government and political organization - they did so in a native world where interactions of trade, diplomacy, and association with both native communities and individuals were unavoidable, especially when native power is considered.

Early accounts of English settlement and ethnographies of the natives they encountered attempt to map out and understand this native world, all the while sating a European hunger for travel literature and information about the commodities of the New World ${ }^{80}$ By assuming that native political organization and the position of a sachem mirrored European monarchies, Englishmen in New England recognized that natives held claim to territory that extended beyond the boundaries of township. ${ }^{81}$ Edward Johnson noted that when puritans founded the town of Ipswitch in 1634, they settled within the "Saggamooreship, or Earldome of Aggawam, now by our English Nation called Essex." 82 William Wood began his ethnography with "the country as it is in relation to the Indians is divided as it were into Shires, every severall division being swayed

\footnotetext{
${ }^{79}$ Ibid., 78-79.

${ }^{80}$ Wood's New England's Prospect is divided into an initial secton on naturalistic information and a second part on native ethnography, followed by an appendix of native grammar. Wood, New England's Prospect, "The Table," n.p., 111. Thomas Morton similarly structured New English Canaan by dividing the text between ethnography and a narrative of the Plymouth colony. Morton, New English Canaan, 115, 243. Finally, in A Key into the Language of North America, Roger Williams similarly divides his text topically, devoting the initial chapters to information on the natural landscape and objects of North America.

${ }^{81}$ In A Key into the Language of North America, Williams translates the Narragansett word "Sachimaûonck" as "a kingdome or monarchie," and contends in his explanation that "their Government is Monarchicall." Williams, A Key into the Language, 162-63.

82 Johnson, Wonder-Working Providence, 66.
} 
by a severall king." Both Wood and Josselyn, in his Two Voyages to New England, name and map the landscape by highlighting territorial divisions between different native groups. Josselyn identified ten different surrounding groups, while Wood identified seven because he did not subdivide the Massachusetts Indians. ${ }^{83}$ Edward Winslow famously described native geospatial knowledge as follows:

Every sachem knoweth how far the bounds and limits of his own country extendeth; and that is his own proper inheritances. Out of that, if any of his men desire land to set their corn, he giveth them as much as they can use, and sets them their bounds. In this circuit whosoever hunteth, if they kill any venison, bring him his fee ... the great sachims or kings know their own bounds or limits of land, as well as the rest. All travelers or strangers for the most part lodge at the sachim's. When they come, they tell them how long they will stay, and to what place they go. ${ }^{84}$

Entering this native world, the English recognized that diplomacy with these various groups was of crucial importance for their continued safety and benefit, as Winslow reported that the rumor of Massasoit's death greatly worried him because that would bring to the sachemship Conbatant, "a hollow-hearted friend towards us." Though he and the native interpreter Hobbamock had earlier provoked Conbatant's enmity, Winslow records that they traveled to him "to enter into more friendly terms with him." ${ }^{95}$ Diplomacy and amicable relationships with the surrounding sachems and neighboring communities became less of a priority as English strength grew in relation to Native American power, eventually erupting with the Pequot War and simmering tensions with the Narragansett and Mohegan, but in the earliest phase of colonization the native world shaped interactions between these two communities. In early encounters with these strange newcomers, Massachusett, Narragansett, Pequot, and all Native Americans in the region also

\footnotetext{
${ }^{83}$ Wood, New England's Prospect, 63-64. Josselyn, Two Voyages to New England, 96-97.

${ }^{84}$ Edward Winslow, "Good News from New England,", in Chronicles of the Pilgrim Fathers of the Colony of Plymouth, From 1602 to 1625. Now First Collected From Original Records and Contemporaneous Printed Documents, and Illustrated With Notes, ed. Alexander Young (Boston: Charles C. Little and James Brown, 1841), $361-62$.

${ }^{85}$ Ibid., 315-16.
} 
evaluated the English and attempted to devise the best ways in which to utilize their presence in the native world.

Native Americans who first encountered the English during the early decades of the seventeenth century confronted these strangers based on their understanding of the natural world and the forces that animated it. Edward Johnson recorded that the Massachusett took note of "that perspicuous bright blazing Comet (which was so famously noted in Europe) ... after which uncouth sight they expected some strange things to follow, and the rather, because not long before the whole Nation of the Mattachusets were so affrighted with a Ship that arrived in their Bay, having never seen any before." 86 The arrival of new people who spoke an unintelligible language, possessing pallid skin and facial hair, along with mysterious and unknown material objects was an event that forced native populations to consider the place of these new visitors. "Place" included both cosmological characteristics, as certain Englishmen seemed interested in understanding the origins of their people and explaining the nature and power of their own gods, and physical characteristics, as these new arrivals were set on building their own villages in close proximity. Thus, the Massachusetts, Narragansett, Mohegan, and other groups the English encountered each considered the health of their respective communities and the potential benefits or dangers that English settlement posed to them. In order to harness the powerful manitou the English seemingly possessed, they attempted to integrate them into their own trading and diplomatic networks. They likewise evaluated the English and their adherence to diplomatic

\footnotetext{
${ }^{86}$ Johnson, Wonder-Working Providence, 15. Johnson continues to describe the reaction of the Massachusetts when they saw the ship, likening it to an animal or "monstrous thing" that they knocked on and tried to understand. As Hall has noted in Worlds of Wonder, Days of Judgment, with his explication of European magical beliefs, the English themselves interpreted the comet as a sign of the great work that God was to do in the country (15-16). Similarly, Josselyn recorded that "they tooke the first Ship they saw for a walking Iland, the Mast to be a Tree, the Saile white Clouds, and the discharging of Ordinance for Lighting and Thunder, which did much trouble them.” Josselyn, Two Voyages to New England, 87.
} 
treaties and native concepts of justice to determine whether or not they could be trusted and treated as close allies.

In comparison to the puritans, who held to a strict form of monotheism, the animistic properties of native religion, with its multiplicity of manitou and potential for discovering new and more powerful sources in the world, ensured that at a conceptual level it was far less difficult for groups like the Massachusett or Narragansett to engage the puritans' god as a source of power in the world. Roger Williams wrote in astonishment that the Narragansett "will generally confess that God made all: but then in speciall, although they deny not that English-mans God made English Men, and the Heavens and Earth there! yet their Gods made them and the Heaven, and Earth where they dwell." ${ }^{, 87}$ When Edward Winslow attempted to explain English beliefs, particularly the Ten Commandments to the Narragansett, his hosts concluded that "they believed almost all the same things, and that the same power that we called God, they called Kiehtan," though the commandment they most objected to was the seventh, with its strict emphasis on monogamy. ${ }^{88}$ Winslow also emphasized that the puritans thanked God for the good events in their lives and the food that they managed to acquire, which parallels Williams' observation of the Narragansett: "If they receive any good in hunting, fishing, Harvest \&c. they acknowledge God in it." ${ }^{\prime 99}$ By linking natural events and objects to supernatural provenance, natives could reasonably conclude that the English held to a similar cosmology and understanding of

\footnotetext{
${ }^{87}$ Williams, A Key into the Language, 147-48. The tendency in English accounts of native religion was either to associate native beliefs with misguided or naturalistic beliefs that were not fully-formed as a religion, or to denigrate practices and beliefs as machinations and delusions given to the people by Satan. The dualistic binary between good and evil forces in Puritan theology offered a convenient and compelling explanation of the cultures that Puritans encountered, which is further discussed in the Puritan response to natives and what they represented to their communities in this same section below. Here is a brief, but representative example: When he finally discusses religion in Wonder-Working Providence of Sions Saviour, Edward Johnson claimed that natives "were the most destitute of any people yet heard of, the Divel having them in very great subjection, not using craft to delude them, as he ordinarily doth in most parts of the World: but kept them in a continuall slavish fear of him." Johnson, Wonder-Working Providence, 225.

${ }^{88}$ Winslow, "Good News", 325-26.

${ }^{89}$ Ibid., 325. Williams, A Key into the Language, 148.
} 
manitou's power in the world. As such, they frequently sought to acquire English sources of manitou through diplomacy, trade, or theft. The acquisition of new manitou, along with the goodwill of its bearers, would continue to strengthen the community.

The connection between material objects and powerful manitou ensured that the first natives encountered by the English quickly sought to understand and acquire these goods, for both practical and spiritual reasons. Wood noted that "they doe much extoll and wonder at the English for their strange Inventions," such as the windmill. Of their first encounters with iron plows, Wood noted that:

The Indians seeing the plow teare up more ground in a day, than their Clamme shels could scrape up in a month, desired to see the workemanship of it, and viewing well the coulter and share, perceiving it to be iron, told the plow-man, he was almost Abamocho, almost as cunning as the Devill; but the fresh supplies of new and strange objects hath lessen'd their admiration, and quickned their inventions, and desire of practicing such things as they see, wherein they express no small ingenuitie, and dexterity of wit, being neither furthered by art, or long experience. ${ }^{90}$

Similarly, the first encounters between settlers and the Massachusetts recorded by Edward Johnson in Wonder-Working Providence of Sions Saviour describes the exchange of beaver pelts by natives for copper kettles offered by the English. Johnson writes that they "were much delighted with the sound" when they knocked the kettles, "and much more astonished to see they would not breake, being so thin." Apparently they were willing to part with a great number of pelts, which led Johnson to conclude that God desired for the English to plant there "in hope of a rich Trade for Bever-skins. ${ }^{״ 1}$ As natives overcame their initial fears and hesitations in these first encounters, they quickly sought to acquire these strange new goods for their own individual and communal benefit. At the same time, they also remained hesitant to fully welcome these

\footnotetext{
${ }^{90}$ Wood, New England's Prospect, 87-88.

${ }^{91}$ Johnson, Wonder-Working Providence, 15-16.
} 
newcomers into their communities for fear of the malevolent intent that they might harbor, especially as disease outbreak began to take its toll on native communities throughout the region.

While native acquisitiveness is a common theme in the early history of transcultural encounters in New England, the first bouts of plague led neighboring Algonquians to link English material objects and their manitou with current problems. At a pitched moment in Winslow's narrative when the Narragansett sachem Canonicus challenged the English by sending them a rattlesnake skin - symbolically significant with the connection between snakes and Abbomocho - Bradford and Standish decided to stuff the snakeskin with gunpowder and return it as a counter-challenge. Winslow writes that the action "was no small terror to this savage king; insomuch as he would not once touch the powder and shot, or suffer it to stay in his house or country." $" 92$ Winslow does not explicitly state why this action so troubled Canonicus, but a later exchange with Tisquantum inadvertently reveals a connection between gunpowder, plague, and manitou. According to Winslow, Tisquantum had committed a "wicked practice" by spreading rumors to the surrounding native communities that the English had the plague buried within their storehouse and would send it out at their pleasure. Hobbamock had seen broken ground in the storehouse and inquired what was there, and Tisquantum had told him that it was the plague. Hobbamock then asked the English if this were true, which they strenuously denied. ${ }^{93}$ As disease outbreaks continued to take their toll on indigenous populations, some native communities thought it better to break off relations with the English or to attack them and drive the European manitou from their land. Others attempted to understand the English and their religious practices, as William Wood noted that natives "frequent often the English Churches,

\footnotetext{
${ }^{92}$ Winslow, "Good News", 283-84.

${ }^{93}$ Ibid., 291-92. Morton also recounts this story in New English Canaan, stating that it was not long after this exchange that a Sachem bordering on the English came and requested that the English unleash the plague on their enemies, "promising that the himselfe and all his posterity would be their everlasting freindes, so great an opinion he had of the English." Morton, New English Canaan, 244-45.
} 
where they will sit soberly, though they understand not such hidden mysteries."94 They seemingly determined that the dangers of English manitou were worth facing in exchange for favor and power, especially in strengthening their own diplomatic and trading networks.

The Narragansett and Massachusett both worked to draw the English into close alliances with their communities through trading and diplomacy, though at times individuals like Tisquantum and Hobbamock attempted to manipulate English favoritism to their own advantage. Winslow recorded that the Plymouth colony had promised to trade with the Massachusett for furs in March of 1622, but that Hobbamock warned them of a rumor that the Massachusett and Narragansett were plotting to kill Standish and the traders who went and also assault the Separatist settlement while the soldiers were away. He also implicated Tisquantum in the plot, and as the Plymouth colonists worked to uncover the plot and build a better relationship with the Narragansett and their leader Massasoit, they began to realize that Tisquantum was using his trusted role as interpreter for the colonists "to persuade them he could lead us to peace or war at his pleasure, and would oft threaten the Indians, sending them word in a private manner we were intended shortly to kill them, that thereby he might get gifts to himself." 95 Similarly, Winthrop recorded in the 1631 account from his journal that a Connecticut sachem named Wahginnacut came to Boston carrying a letter from John Endecott stating that he desired the Englishmen to live near him, offering to find them corn and to give them eighty beaver skins yearly. ${ }^{96} \mathrm{~A}$ week or so earlier Winthrop recorded that he had entertained a Neponset sachem named Chickatabot and his party, presenting Winthrop with a hogshead of beer and leaving with "cheese and peas

\footnotetext{
${ }^{94}$ Wood, New England's Prospects, 88.

95 Winslow, "Good News", 285-89.

96 John Winthrop, Winthrop's Journal “History of New England” 1630-1649, ed. James Kendall Hosmer, Vol. I (New York: Charles Scribner’s Sons, 1908), 61.
} 
and a mug and some other small things" after spending the night and dining. ${ }^{97}$ The day to day records of Winthrop's journal attest to the frequency with which natives adjacent to the English settlement in Boston drew the English into pre-established modes of diplomacy. As allies, these sachems expected the English to maintain near-exclusive agreements to treat and trade with them, and to come to their aid against their neighboring enemies. By integrating the English into their networks in this way, sachems expected to strengthen their power, prestige, and manitou. English leaders frequently reciprocated by giving gifts to the sachems that they treated with diplomatically. ${ }^{98}$

In their early interactions with native communities, the English were chiefly concerned with protecting their own settlements from danger and attack, evaluating the nature and organization of native communities, and distinguishing between friendly and dangerous groups. From a religious standpoint, English observers speculated on the nature of native religious practice and attempted to understand where North America's population initially came from based on their understanding of biblical history. Securing their position in the area, the English quickly began to expand further within the region, which raised greater tensions with their native neighbors. The first encounters between Bradford's company and Massasoit have already been discussed above, but the experiences of Winthrop and the Massachusetts Bay Colony demonstrate a similar pattern of native diplomacy, captured in greater detail within Winthrop's journal.

Throughout the early years of the Massachusetts Bay Colony, Winthrop records numerous instances in his journal where he attempted to solicit goodwill from neighboring Massachusett communities, punished individuals who could have jeopardized relations between

\footnotetext{
${ }^{97}$ Ibid., 59.

${ }^{98}$ Little, Abraham in Arms, 14-16, 34-35. Bragdon, Native People of Southern New England, 143-148, 153-155.
} 
the communities, and expressed positive sentiments for neighboring leaders. When Chickatabot came to trade two beaver skins for clothes in 1631, Winthrop insisted that his tailor make a suit of clothes for the sachem, and he dined with him when he returned to pick up the gift. He later conferred again with the sachem when one of Chicatabot's people killed a pig and Winthrop requested payment for the incident. ${ }^{99}$ That same year, Winthrop ordered lashings for one of the young settlers because he solicited a native woman for sex. His wife apparently learned of the incident and complained about his actions, which potentially tarnished the nature of the colony's religious covenant with God and could have complicated native diplomacy. That very same month, the colony's court censured Josias Plaistowe and his servants for stealing corn from Chickatabot's village. Chickatabot was present for the ruling, where the court ordered the colonists to pay the corn back double. The colony's leaders also stripped Plaistowe of his gentleman title and fined him five pounds, while his men were summarily whipped. ${ }^{100}$ This case of early justice in favor of a native sachem is worth noting because it demonstrates the measures Winthrop took to placate the sachem and promote diplomacy while also purifying his community of sin and wrongdoing. On October 22, 1631 Winthrop recorded that he received a letter from Captain Thomas Wiggin of Pascataquack divulging events of a murder committed by sachem Squidrayset and his men against traders who had plagued the nearby native community. Though Wiggin requested that the governor send twenty men to attack Squidrayset's village, Winthrop "thought best to sit still awhile" because of the weather. That said, Winthrop also commented that Bagnall, one of the traders, "was a wicked fellow, and had much wronged the Indians," a comment that suggests he tacitly approved of his fate, given God's provenance in punishing the

\footnotetext{
${ }^{99}$ Winthrop, Journal, 62, 64.

${ }^{100}$ Ibid., 67-68.
} 
wicked. ${ }^{101}$ In 1634 , the colony also brokered a peace with the Pequot following native methods of gift exchange while attempting to apprehend a few Pequot warriors who had killed some Englishmen prior to the meeting. ${ }^{102}$ Early diplomatic meetings in the colonies recognized the lack of English power relative to native strength in the region, and leaders frequently sought to balance their aims with the diplomatic norms followed by the sachems they encountered.

Early colonial writers and leaders also attempted to distinguish between native groups that were more beneficial to consort with and others who were more likely to be enemies, though native informants played a hand in shaping these notions when they introduced the English to the regions where they settled. Wood recorded that his informants greatly feared the Mohawks, as they were "a cruell bloody people, which were wont to come downe upon their poore neighbours with more than bruitish savageness, spoyling of their Corne, burning their houses, slaying men, ravishing women." Hearing tales of Mohawk ritual torture of captives, Wood condemned this as cannibalism and concluded that "the very name of a Mowhack would strike the heart of a poore Abergenian dead." 103 In Wood's text the "Tarrenteenes" did not fare much better, as he noted that "our Indians doe feare them as their deadly enemies; for so many of them as they meete they kill," though he spoke surprisingly well of the Pequot, describing them as "a stately warlike people, of whom I never heard any misdemeanor; but that they were just and equall in their dealings; not treacherous either to their Country-men, or English." The Narragansett were similarly described as numerous, rich, and industrious, as they were devoted to producing

\footnotetext{
101 Ibid., 69.

102 Ibid., 138-40.

${ }^{103}$ Wood, New England's Prospect, 64. Wood similarly describes the various groups that he laid out previously in a generalization about the groups inhabiting New England. He also describes each groups as physically different:

Mohawks were "a people of a tall stature, of long grimme visages, slender wasted, and exceedingly great armes and thighs, wherein they say their strength lyeth." (Ibid., 64) Aberginians (Massachusetts) were described as "betweene five or six foote high, straight bodied, strongly composed, smooth skinned, merry countenanced, of complexion something more swarthy than Spaniards ..." (70).
} 
wampum and stone pipes. ${ }^{104}$ However, Winslow described the Narragansett in 1621 as breathing "forth many threats against us, notwithstanding their desired and obtained peace with us in the foregoing summer," attributing this information to "the common talk of our neighbour Indians on all sides." 105 Josselyn attributed native hostility and violence to humoral medicine, reasoning that "their bloud dryed up with overmuch fire," creating in them a disposition "very inconstant, crafty, timorous, quick of apprehension, and very ingenious, soon angry, and so malicious that they seldom forget an injury."106 Edward Johnson similarly wrote that the Pequots were "a barbarous and bloudy people," and that "these savage Indians lying to the South-west of the Mattacusets, were more warlike than their Neighbouring Nations, the Narrowganzet or Niantick Indians," going on to describe the damage that they did with rifles acquired from the Dutch. These assumptions, shaped by native informants, channeled English interaction and relations in North America toward particular groups and individuals at the expense of others. Coupled with diplomatic connections forged between the English and their closer allies, native information at times pushed the English into conflict with enemies as a part of native strategies to leverage English support for their own people.

English settlers also faced the task of conceptually placing natives in North America within their biblical and naturalistic understandings of the world and its people. Traditional Christian thought held that the world's population came from Noah's sons, Shem, Japheth, and Ham. The Geneva Bible stated in Genesis 9:19 that "of them was the whole earth overspread," and the account continues in the next chapter to trace their respective lineages, which were

\footnotetext{
${ }^{104}$ Ibid., 67, 69.

105 Winslow, "Good News", 280.

106 Josselyn, Two Voyages to New England, 98.
} 
divided by their respective languages into nations. ${ }^{107}$ Roger Williams stated that "from Adam and Noah that they spring," yet native assertions posed a problem because the Narragansett insisted that "they have sprung and growne up in that very place, like the very trees of the Wildernesse." 108 However, through his observations and ethnographic writing, Williams asserted that native language, rituals of anointing, the giving of dowries at weddings, and the practice of sequestration for menstruating women indicated that the natives may have descended from the Jewish people. ${ }^{109}$ Josselyn noted in his geopolitical division of the region that "the people that inhabited this Countrey are judged to be of the Tartars called Samonids that border upon Moscovia," highlighting their language and physical characteristics as additional proof of their heritage. ${ }^{110}$ The fascination with a Jewish lineage for their native neighbors eventually fueled efforts to engage them in overtly missionary endeavors, especially during the millennialism and social upheavals triggered by the English Civil War. Erstwhile Jews or simple barbarians, English observers consistently judged their native neighbors as deficient in matters of social organization, behavior, and religious belief in comparison to their own culture and religion. During the initial decades of English weakness and communal instability the need for safety and stability superseded these judgments, though they would prove influential as English strength grew and English settlement eclipsed particular native communities.

\footnotetext{
${ }^{107}$ Genesis 9:19, Genesis 10: 1-32. The Geneva Bible footnotes for this section of Genesis emphasizes that Ham's son Canaan was the father of a wicked nation, as "Ham and his posterity were accursed." Japheth's descendants became the Gentiles, who "were separated from the Church," and "should be joined to the same by the persuasion of God's Spirit, and preaching of the Gospel." 1599 Geneva Bible, "footnotes," 12. Depending on the interpretive mindset of the English, natives could be regarded as Gentiles who should be preached to, or perhaps the descendants of Ham - Canaanites who were cursed by God. The interpretive ambiguity as to the origins of Native Americans from an English perspective is worth noting, as it could religiously justify actions such as Eliot and Mayhew's later efforts to convert natives, as well as violent acts of war against groups like the Pequot or Metacom's warriors.

${ }^{108}$ Williams, A Key into the Language, 23.

${ }^{109}$ Ibid., 24. John Eliot later continued the common rumor of a Jewish connection to Native Americans in a letter to Thomas Thorowgood, who wrote a book titled Jews in America, or Probabilities that the Americans be of that Race. Eliot apparently read the book and thought it worth his time to respond with more detailed notions drawn from the story of Genesis to raise this as a probable theory of native origins.

110 Josselyn, Two Voyages to New England, 96-97.
} 
English observations of native culture frequently discounted religion, arguing that North America's indigenous population led a barbarous life devoid of such higher devotion. Later accounts from settlers who held sustained contact and interaction with natives quickly realized that this was not the case, as Thomas Morton and Roger Williams both attest to in their writings. The challenge that Englishmen faced in light of this new knowledge was determining its origin and the potential impact that this could have on their own citizens. ${ }^{111}$ By and large, puritan observers cast native practices and belief as backwards or ill-informed, and hinging on the demonic. As such, religion was an area where the English wasted no short span of time in asserting that the proper course of action was to convert or eradicate these aspects of native culture. ${ }^{112}$ The emphasis on demonic forces and the influence of Satan, found frequently in

\footnotetext{
${ }^{111}$ Early studies from the "New Indian History" emphasize the cultural enmity that many English colonists had for natives and their traditional lifeways that ran contrary to English practice. Unfortunately, this has been confused with a racial distinction or justification for English actions, as G. E. Thomas has done in "Puritans, Indians, and the Concept of Race." Thomas argued against Alden Vaughan's New England Frontier: Puritans and Indians, 16201675, pointing out the numerous instances of Puritan mistreatment of natives in the early history of contact and settlement. G. E. Thomas, "Puritans, Indians, and the Concept of Race," The New England Quarterly 48 (1975), 3-4. While these atrocities certainly happened, it is anachronistic to attribute them to nascent racism, when Puritan theology and European natural history, a derivation of Pliny, contrasted societies through the barbaric/civilized dichotomy. A more sophisticated treatment in recent years is Zubeda Jalalzai's "Race and the Puritan Body Politic," which argues that metaphors of a corporeal body better represent Puritan communities and their interactions with outsiders rather than the "City on a Hill" and racial constructs. Jalalzai argues that Puritans were conscious of the need to maintain a pure communal body when interacting with natives, which accounts for their early emphasis on civilizing projects. Zubeda Jalalzai, "Race and the Puritan Body Politic," MELUS 29 (2004), 260, 265. Edward E. Andrews has noted that "New England Puritans expressed a complex range of impressions about Indian religion," though most of them concluded that Indians could be reformed and instructed in proper Christianity. Edward E. Andrews, Native Apostles: Black and Indian Missionaries in the British Atlantic World (Cambridge: Harvard University Press, 2013), 24.

${ }^{112}$ In the introduction to his language primer, Roger Williams emphasizes the great lengths that he went to in order to author a useful text on native language and religion, declaring them to be lost and misguided in their beliefs. Resting in God's providence, he wrote "I know not with how little Knowledge and Grace of Christ the Lord may save, and therefore will neither despaire, nor report much." Williams, A Key into the Language, 25. Cathy Rex has analyzed the different iterations of the Bay Colony seal and argues that it was "a barometer of sorts, reflecting the diffuse and fluid nature of colonial identity, and the conflicted repulsion from/desire for Nativeness that not only underpins that identity, but gives it existence." According to Rex, uncertainty governed relations with Natives, and even more so in the case of Natives closely associated with Christianizing projects. Cathy Rex, "Indians and Images: The Massachusetts Bay Colony Seal, James Printer, and the Anxiety of Colonial Identity," American Quarterly 63 (2011), 64. One of the great ironies in the Puritan response to native religious practices is the fact that they held a variety of beliefs in folk magic and healing rituals themselves which could manipulate forces in the world and provide real benefits to magic's practitioners. These beliefs and practices put common users in conflict with Puritan leaders, who sought to stamp out these forces within their own communities. Richard Godbeer, The Devil's
} 
settler accounts of native religion, represented a grave threat to the English as transplants in North America. While they had faced persecution for their particular beliefs in England they recognized the debilitating effects of Satan on the uncivilized denizens "beyond the pale." Thus, the early settlers frequently attempted to isolate their communities from becoming too familiar with their neighbors beyond Boston or Plymouth, however unsuccessful these efforts actually were. At the same time, they also recognized that the "wild" environment of the region held depredating effects on the moral character of their own citizens. ${ }^{113}$

Puritans in Massachusetts Bay wasted no time expanding beyond the coast and the town of Boston, settling Watertown, Roxbury, Dorchester and Salem in 1630. Communities quickly sprung up throughout the region, among them Ipswich, which was founded in 1634, Dedham (1637), and Sudbury (1640). ${ }^{114}$ English settlers benefitted greatly from the weakening of native polities through disease and factionalism and often built their communities atop previous native settlements where they could take advantage of the fields that native hands had previously tilled and cultivated. ${ }^{115}$ European expansion raised new questions for both English and native

Dominion: Magic and Religion in Early New England (Cambridge: Cambridge University Press, 1992), 16-17, 2425.

${ }^{113}$ Bradford and the Plymouth leaders attempted to initially bar the colonists from trading for "furrs, and such like commodities, till the time of the comunallitie be ended." Bradford, Of Plymouth Plantation, 95. In 1632 Winthrop and the colony's leaders whipped and branded a man named Hopkins, a resident of Watertown, for selling a gun and a pistol, along with powder and shot, to a native. Winthrop and the Bay Colony established similar trading rules in 1636. Winthrop, Journal, 90, 190. Tose who spent too much time with natives, such as Thomas Morton, provoked the ire of leaders such as William Bradford. Selling guns to natives and reveling with them were the chief complaints that led to Morton's banishment from the colony, prompting him to author his own counter-narrative of settlement and society in Plymouth where he frequently denigrated the Separatists and claimed to find more justice, hospitality, and moral behavior among his native companions. The tension in the Plymouth community, particularly the Morton fiasco, is discussed at length below.

114 Johnson, Wonder-Working Providence, 44-45, 66, 125, 141-42.

115 William Cronon, Changes in the Land: Indians, Colonists, and the Ecology of New England (New York: Hill and Wang, 2003), 88-92. Cronon also emphasizes that depopulation triggered by disease made it easier for the English to justify their claims to land because property was maintained through improvements to the land, which natives could no longer do. "Over and over again," writes Cronon, "New England towns made their first settlements on the sites of destroyed Indian villages" such as Plymouth. Though the Plymouth colonists settled atop an older native village, the timing of their landing and a shortage of supplies ensured that they resorted to pilfering from nearby natives according to Neal Salisbury. Salisbury, Manitou and Providence, 113-14. In a 1639 claim against John Wheelwright over a former native community called Winicowett, Winthrop noted that Massachusetts Bay claimed the land under 
communities. Puritans near Massachusetts Bay and Separatists in Plymouth had to contend with issues of governance for these communities, both politically and religiously, as well as diplomacy with natives as they pushed deeper into indigenous territory. Confronting the English, native communities had to contend with disease epidemics, the failures of traditional manitou, and diplomatic tensions with the English and their neighboring enemies. For both puritans and Native Americans, the future of their communities appeared tenuous as they confronted these dire threats.

\section{Communities Subverted: Facing the Future}

During the early decades of colonization both puritans and Native Americans faced challenges to their respective communities. Equally true for both groups was the tendency to attribute causation in some instances to the neighboring "other" community. For Native American groups, the expansion of epidemic disease and puritan settlements beyond the coastline presented tremendous threats to community integrity. Some decided to strike back against the puritans and their manitou, most notably in the Pequot War in 1637, which inspired a brutal puritan response. The failure of native manitou to counter this growing English threat, along with the loss of elders and traditional leaders, represents a profound loss of confidence for Native Americans in close proximity to the English, which created a growing sense of factionalism and infighting within native communities. If equilibrium and its maintenance was a hallmark of early Native American society and culture prior to English settlement, then the period of 1635 to 1650 represents a tumultuous disruption. For some groups, entering into an even closer association and integration with puritan settlements appeared to be the most viable

the principle of "vacuum domicilium" and proper possession through improvement, and that "the Indians having only a natural right to so much land as they had or could improve, so as the rest of the country lay open to any that could and would improve it." Winthrop, Journal, 294. 
option for rebuilding amidst this chaos, which led to the Praying Town settlement projects overseen by John Eliot beginning in 1648 .

The paramount challenge that Native American communities across the region faced in the wake of contact with Europeans was the periodic outbreak of disease epidemics which decimated villages and entire regions as illnesses spread across trading networks. Bradford noted that Tisquantum took Edward Winslow and another man named Hopkins to his community about forty miles away from their settlement, which was then sparsely populated after thousands had died, "they not being able to burie one another; ther sculls and bones were found in many places lying still above ground, where their houses \& dwellings had been."116 The inability to observe proper burial rites would have convinced many natives that their deceased relatives were angry with them and possibly punishing them in death. These former towns and communities were now the loci for rifts in the natural world where malevolent forces and manitou held sway. Winthrop recorded in 1633 that Chickatabot, the sachem of the Naponsett, and many of his people had died of smallpox, and that the English took in their children. In 1634 he recorded a similar entry, noting that another bout of the plague left only three surviving native children in yet another smallpox outbreak. ${ }^{117}$ For the children who lived in English settlements after disaster struck their families, the break from traditional culture would have been almost complete. The communities that survived plague outbreaks in truncated form suffered a similar cultural blow through the loss of traditional sachems and powwows, along with the cultural knowledge that community elders possessed.

Despite their best efforts to accumulate powerful manitou from close association with the English, even their allies and cultural brokers were susceptible to diseases from which they held

\footnotetext{
116 Bradford, Of Plymouth Plantation, 77-78.

117 Winthrop, Journal, 111, 119.
} 
no biological immunity. Winthrop recorded that John Sagamore, one of the colony's earliest native contacts, died of smallpox along with "almost all his people." The sickness was apparently so bad that on just one day the English helped bury over thirty people. This sickness also took James Sagamore, who requested that he die among the English and "serve their God." Sagamore gave a good quantity of wampum and a variety of gifts to have the English take in his son and promised to serve the English god if he would heal him of the plague. Without a doubt, Sagamore hoped that powerful manitou would aid him, though in the end he too succumbed to the plague as it spread to Pascataquack and decimated all but one or two of the town's inhabitants. By 1634 Winthrop had received reports that smallpox had spread "as far as any Indian plantation was known to the west, and much people dead of it, by reason whereof they could have no trade." ${ }^{\prime 18}$ The severance or disruption of trading networks further deprived native communities of the unique ritual objects that traveled throughout the northeast, along with the manitou that they provided as an efficacious treatment to disease and other illness. For a number of surviving communities this contributed towards enmity against the English, who appeared to callously sit by as native communities suffered or, under the worst interpretation, actively used their manitou against their native friends despite assurances of amity and peaceful intent.

Some native communities chose to strike back against the English in an effort to remove this threat and restore balance to the region, most notably in the Pequot attacks against the colonies. Others grappled with internal dissention over the best course of future action. By 1636 Connecticut settlements extended beyond the bounds of civil authority and individual colonists began brokering land deals with local sachems themselves. Coupled with the more militant stances Massachusetts Bay and Saybrook adopted toward the Pequot, they understandably felt

${ }^{118}$ Ibid., 114-15, 118. 
surrounded and isolated as their allies deserted them. ${ }^{119}$ The murder of John Oldham served as a principal catalyst for war when the Eastern Niantics blamed the Pequot for his death. Winthrop recorded that all of the Narragansett sachems except Canonicus and Miantonomo were involved in the act, which he attributed to Oldham's trading and making peace with the Pequot in 1635. He later recorded the Pequot and Narragansett had forged a truce because the Pequot had persuaded some of the Narragansett that the English sought to destroy all Indians, though the English attempted to assure the Narragansett that they harbored no ill intent towards them and eventually enlisted their help in fighting the Pequot. ${ }^{120}$ In retaliation the English began burning Pequot homes and crops in September 1636 which prompted the Pequot to retaliate with a siege against the English at Fort Saybrook that lasted for nine months.

The failure of that conflict to shift the balance of power in favor of natives in the region further contributed to the breakdown of indigenous power, as the English massacred somewhere between three hundred and seven hundred Pequot men, women, and children at their Mystic River settlement and turned the survivors over to the Narragansett or sold them into Caribbean slavery. ${ }^{121}$ In the wake of the war, Ann Little notes that "the four decades between the Pequot War and King Philip's War were not a time of calm in the northeastern borderlands" as native communities increasingly faced factionalism and tension with their neighbors, both native and English. ${ }^{122}$ Indeed, the diplomatic landscape painted by Winthrop and Bradford in their colonial histories appears marked by uncertainty on the part of both natives and Englishmen, as sachems

\footnotetext{
${ }^{119}$ Salisbury, Manitou and Providence, 217-18.

${ }^{120}$ Winthrop, Journal, 184-85, 190.

${ }^{121}$ Salisbury, Manitou and Providence, 221-25. Colin G. Calloway notes that English ferocity particularly unnerved their Narragansett and Mohegan allies, as English methods of war produced greater casualties than the regional pattern of captivity during warfare. Colin G. Calloway, New Worlds For All: Indians, Europeans, and the Remaking of Early America (Baltimore: Johns Hopkins University Press, 1997), 97-8.

${ }^{122}$ Little, Abraham in Arms, 49.
} 
bordering English territory sought assurance that the English would not fall on them as they had done the Pequot, instead aiding them if their traditional enemies were to attack. ${ }^{123}$

Disease and warfare decimated native communities, lowering their physical populations, disrupting trading networks, and stealing the cultural knowledge of every village elder, powwow, and sachem who succumbed to foreign infection. Coupled with the advancing spread of English colonization, their relative immunity to the same outbreaks that affected natives, and their growing hegemony over the region, the chances of native survival and rebuilding seemed especially bleak in the 1630s and 1640s. Winthrop and Bradford both record that diplomacy amongst natives became increasingly strained during this period, particularly for the Massachusetts, Pequot, Narragansett, and the Mohegan. Infighting increasingly destabilized polities as surviving sachems faced difficulty in controlling and directing their communities. Some groups attempted to isolate themselves from Europeans altogether and renounced contact and trade. Winthrop recorded in 1638 that "the Indians, which were in our families, were much frightened with Hobbamock (as they call the devil) appearing to them in divers shapes, and persuading them to forsake the English, and not to come at the assemblies, nor to learn to read, etc." ${ }^{124}$ Indian servants, who appear to be the subject of Winthrop's anecdote, similarly avoided cultural association with the English despite their servile position within English communities. It is unsurprising that native attacks against lone colonists caught outside of settlements increased during this period as well. ${ }^{125}$ For a people who conceptualized their communities as fitting within a world imbued with manitou and balanced amidst a variety of powerful forces, the apparent imbalance introduced by the English threatened to destroy them. While some turned their energy against traditional enemies, others chose an ascetic path and withdrew from contact with the

\footnotetext{
${ }^{123}$ Bradford, Of Plymouth Plantation, 216-227. Winthrop, Journal, 269, 272, 289.

${ }^{124}$ Ibid., 260.

${ }^{125}$ Bradford, Of Plymouth Plantation, 214-15.
} 
English. Still others chose to enter into an even closer association with the English in the hope that their protection and society would accommodate Native Americans with place and space to rebuild. Nevertheless, purging the community and the idea of fixing imbalances guided native decision-making during this tumultuous period.

During this same period, puritans faced a similar blow to their confidence and the mission of building a godly community in North America, albeit under differing circumstances. Despite the healthy expansion of communities, the colony faced internal challenges that came with regulating the behavior of covenant church members and the uninitiated. The greatest and most well-known challenges of this period were the banishment of Roger Williams and Anne Hutchinson, though a number of misdeeds and suspect actions from lesser known individuals led governors Winthrop and Bradford to punish them. Punishment involving colonists and Native Americans attests to the failure of leaders to channel interactions into a purely diplomatic association between community leaders. In the case of Thomas Morton, one of the colony's earliest first-hand critics, his close association with Native Americans appears to be a particular source of conflict between himself and the colony's leaders. Thus, the earliest myth of declension formed out of the challenges that came with putting religious ideology into practice in a Native American environment, which was unsettling for many puritan leaders. However, these tensions temporarily subsided as puritans diverted their attention to events transpiring in England with the advent of civil war and the creation of a puritan regime under Oliver Cromwell.

Almost immediately, puritan and Separatist leaders faced challenges from within, as the people in their communities often appeared unable to uphold such rigorous standards of godly association. In 1630 Bradford and the leaders of the Plymouth colony carried out the first government execution in the colony when they killed John Billington, a man whom Bradford 
accused of being of "one of the profanest families amongst them," for shooting and killing a young man named John Newcomin in a dispute over unnamed former issues. ${ }^{126}$ Confronting internal discontent with the nature of Separatist leadership in Plymouth, Bradford's narrative history of the colony also devotes a lengthy explanation in 1624 to the misdeeds of John Lyford and John Oldham, who built a faction of similarly disgruntled residents and wrote disparaging letters about the colony which Bradford intercepted. Lyford and Oldham's hostility and refusal to submit to Bradford's authority eventually led to their expulsion from Plymouth, where they found refuge in the Massachusetts Bay Colony. ${ }^{127}$ Lyford again entered Bradford's narrative in 1625 when he and his wife had a dispute over a child he had previously fathered before he married her, and her fears that God would punish him by delivering her to Indian men for their sexual enjoyment. ${ }^{128}$ Shortly after puritans arrived in North America, Winthrop recorded in 1631 that he traveled to Watertown to settle a dispute between the church congregation and their minister over who would serve as elders, though it would not be the last incident in the early history of the puritan experiment. By 1646 the Massachusetts Bay Colony leaders deemed it necessary to author a formal law code which prescribed harsh punishments of whippings for drunkenness and fornication, boring through the tongue with a hot iron for swearing and cursing, and death for adultery and witchcraft. ${ }^{129}$ The most popularized threats to the colony came with the disputes caused by Roger Williams and Anne Hutchinson. Williams' critique of crown

\footnotetext{
${ }^{126}$ Bradford, Of Plymouth Plantation, 155.

${ }^{127}$ Ibid., 106-14.

${ }^{128}$ Bradford cites God's threat against David, quoting 2 Samuel 12:11 and the line "I will raise upon evill against thee, and will take thy wives \& give them, \&c." Apparently Lyford had sworn to his wife that he had not fathered a bastard, but the child was brought to them after she had married him. Bradford, Of Plymouth Plantation, 120. It is also interesting, in the scope of communities associating with each other, that Lyford's wife's greatest fear was that she would be the object of his punishment, and that this would take place at the hands of native men.

${ }^{129}$ Winthrop, Journal, 71-72. Josselyn, Two Voyages to New England, 137. On adjudication, Howard Schweber highlights the particular blending of secular and sacred principles in the early law disputes of Puritan Massachusetts, noting that "a common refrain in attacks against the authority of the magistrates was that their laws were not accurate reflections of the divine will." Such challenges could turn a communal dispute into an issue of civil authority as they became more public. Howard Schweber, "Ordering Principles: The Adjudication of Criminal Cases in Puritan Massachusetts, 1629-1650," Law \& Society Review 32 (1998), 368-69.
} 
authority and tendency toward separatism ensured that his numerous disputes with Winthrop as minister of the Salem church eventually led to his expulsion, while Hutchinson's condemnation of puritan ministers and eventual justification of her behavior through divine revelation prompted a similar response from puritan leaders to cleanse the body politic. ${ }^{130}$ Internally, community health and the importance of proper moral behavior led puritan and Separatist leaders to aggressively pursue what they believed to be a clean and upright model society. Within this framework, association with Native Americans could also provoke both tension and punitive responses from authorities, as is particularly revealed in the conflict surrounding Thomas Morton.

Morton had traveled to North America on an exploratory voyage in 1622, but returned in 1624 with a group of eminent men and servants led by Captain Wollaston to found their own community called Mount Wollaston. It did not take Morton long to provoke the ire of Bradford and Winthrop when he roused the indentured servants to oust their commanding officer, Lieutenant Fitcher, in the absence of one of the colony's partners, Mr. Rasdall, and establish a free colony after he learned the servants were being sold to Virginia. According to Bradford, who hardly serves as an unbiased observer, Morton and the villagers entered into a close trade with local Indians and supplied them with alcohol. They also erected a maypole and frolicked with them in a bacchanal celebration, renaming the free town Merrymount. Even more egregious

\footnotetext{
${ }^{130}$ Bradford, Of Plymouth Plantation, 166-67. Winthrop, Journal, 142, 187-88. David Thomson has argued that Eliot's role in the Anne Hutchinson trial contributed to theological shifts which led him to adopt a preparationalist position in his missionary work rather than orthodox Calvinism. David Thomson, "The Antinomian Crisis: Prelude to Puritan Missions," Early American Literature 38 (2003), 403-04, 417. Karyn Valerius has connected Puritan beliefs in spiritual forces and their impact on the physical world in the Hutchinson trial to her supposed "monstrous birth," which Winthrop and other leaders took as a validation of Hutchinson's demonic persuasion and the close connections between monstrosity and heresy in Reformation polemics. Karyn Valerius, "So Manifest a Signe from Heaven': Monstrosity and Heresy in the Antinomian Controversy," The New England Quarterly 83 (2010), 179-80, 192. Both Thomson and Deborah Lucas Schneider have also emphasized that Hutchinson expressed a classical understanding of orthodox covenant theology, and that changes in Puritan understandings of salvation and sanctification led to this conflict, as Puritans believed only one interpretation of scripture could be correct. Deborah Lucas Schneider, “Anne Hutchinson and Covenant Theology,” Harvard Theological Review 103 (2010), $492,500$.
} 
to Bradford was Morton's willingness to trade guns and ammunition to his neighbors, along with lessons in their use and the production of gunpowder and shot. ${ }^{131}$ Merrymount was popular enough to draw a number of colonists to Morton's community and cause the leaders of the surrounding colonies to plot its destruction, sending Miles Standish to attack the town and cut down the second maypole the settlement had erected in 1628 , which was over 80 feet tall and topped with a great pair of deer antlers. ${ }^{132}$ The Plymouth leaders put Morton on trial and decided to maroon him on the Isle of Shoals, where a passing ship later picked him up and carried him to England. After this fiasco, Morton devoted much of his time to launching a legal and polemical attack against the New England colonies, petitioning the king to intercede on their behalf and penning New English Canaan as an attack against the puritans, who acted as the Israelites and despoiled the native Canaan in a repeat of Joshua's biblical conquests. ${ }^{133}$ The behavior of Thomas Morton represented both the undesirable elements which puritans and Separatists sought to extricate from their communities, the "Athisme" that Bradford initially charged Morton with promoting in Merrymount, and also the dangerous result of the potentially degenerative cultural effects of close association with Native Americans. Without firm control and close governance, the natural inclination of many colonists seemed to be towards their indigenous neighbors rather than the strict rules and lifestyle of Plymouth and Massachusetts Bay the governors of the English plantations sought to foster.

Tensions rose in English relations with indigenous communities during this period as English communities proved to be abusive and inconsiderate, based on the prerogative settlers placed on their own culture. As early as 1622, Separatists from the Plymouth colony began provoking the ire of neighboring communities as they set to pilfering native corn - the first of

\footnotetext{
${ }^{131}$ Bradford, Of Plymouth Plantation, 141-43.

${ }^{132}$ Morton, New English Canaan, 267-77.

${ }^{133}$ Bradford, Of Plymouth Plantation, 144-5. Winthrop, Journal, 100-02.
} 
many tense conflicts between these towns. Edward Winslow also recorded in his entry for 1623 that the English habitually broke into native storehouses and dug up buried supplies, which led their neighbors to refuse them any further aid at that time. ${ }^{134}$ The murder of John Oldham and the beginning of the Pequot War, which coincidentally occurred at the same time as the Antinomian controversy, rocked New England in 1636. The destruction of the Pequot served as a means of eradicating an external threat to English communities, and it is telling that they sought to dismember the Pequot communal body by selling a number of captives and villagers into West Indian slavery. ${ }^{135}$

Though they had vanquished the Pequot and secured greater control over the New England region, the English ferocity in war only served to provoke greater tension with neighbors like the Narragansett, who began to rethink their alliance with the English. ${ }^{136}$ Bradford recorded numerous murders in 1644 at the hands of natives and the severance of relations with a number of neighboring communities that had previously negotiated with them. ${ }^{137}$ The situation within English communities fared no better in the aftermath of this conflict, as Bradford recorded "the breaking out of sundrie notorious sins" in 1642, including drunkenness, premarital sex,

\footnotetext{
${ }^{134}$ Winslow, "Good News", 297-98, 327-28. He also notes that some Englishmen argued that if the natives refused to help them they should take what they wanted by force.

${ }^{135}$ Salisbury asserts that the Pequot War was a moment where colonial leaders redefined their purpose in North America, as it marked an ideological turning point towards Puritan ascendency in control over the region. Salisbury, Manitou and Providence, 218-25. Little notes that the Puritan display of savagery during this war, in terms of native understandings of proper masculine conduct during battle, led a number of their allies to abandon them and to placate them with land grants in the aftermath of the conflict. Little, Abraham in Arms, 46-48. In Josselyn's chronology at the end of his Two Voyages to New England, he also highlights the fact that the war and the Antinomian crisis occurred in the same year, estimating that the total loss for the Pequot in the war was about 700 people, including 13 sachems. Josselyn, Two Voyages to New England, 194. Winthrop estimated that between 800 and 900 were killed. Winthrop, Journal, 229-30. In a letter from John Winthrop included in Bradford's Of Plymouth Plantation he notes that the prisoners were divided and dispersed, and that "the Indeans in all quarters so terrified as all their friends are afraid to receive them." Bradford, Of Plymouth Plantation, 186.

${ }^{136}$ The most egregious case of English ferocity was the massacre of the Mystic Pequot, where over 300 were killed, including over 150 women, children, and elderly natives. The violence was so pitched that "divers of the Indian friends were hurt by the English, because they had not some mark to distinguish them from the Pequods, as some of them had," according to Winthrop. Winthrop, Journal, 220.

${ }^{137}$ Bradford, Of Plymouth Plantation, 208-09, 214-15.
} 
adultery, and "that which is worse, even sodomie and bugerie, (things fearfull to name,) have broak forth in this land, oftener than once." He mused that Satan held more power over "these heathen lands," but other causes could be suitable to explain the bad behavior of that year. Using the metaphor of a dam breaking, he concluded that "wikednes being here more stopped by strict laws ... it searches every wher, and at last breaks out wher it gets vente." ${ }^{138}$ Massachusetts Bay faced its own issues of factionalism and internal division in the wake of the Pequot War, as the Roxbury church excommunicated a number of members and the colony faced similar cases of adultery. ${ }^{139}$ Despite the apparently providential successes the English enjoyed with the Pequot War, the colony appeared to fare no better in establishing a truly godly commonwealth.

As the English colonists entered the 1640s the triumph over the Pequot paled in comparison to the continued tensions within their community and with their remaining native neighbors and allies. The growing conflict between the Mohegan and Narragansett, led by their respective sachems Uncas and Miantonomo, deteriorated into open warfare in 1643. Once again, the English had to band together and defend themselves while navigating the intricacies of native diplomacy. Securely settled in the region, though still outnumbered by the combined native communities, the English worked to leverage both protection and a weakening of their enemies while asserting a more dominant role in diplomacy as a whole. ${ }^{140}$ Coupled with continued issues of misbehavior and factionalism within communities and congregations, English settlers had reason to question the vitality of their communities and their commitment to the covenant that they had forged with God. The parallel between the Antinomian controversy and the Pequot War could easily be read as punishment for their failure to maintain a godly community, as do the

\footnotetext{
${ }^{138}$ Ibid., 197-98.

139 Winthrop, Journal, 258, 329.

${ }^{140}$ Bradford, Of Plymouth Plantation, 215-17. Bradford emphasizes the refusal of the English to honor some of the requests of both the Narragansett and the Mohegan.
} 
corresponding tensions in native politics and Puritan behavior in the early 1640s. John Winthrop recorded that the Bay Colony churches held a general fast throughout the colony in January 1637 that reflects the transatlantic connections of global puritanism in addition to their colonial sensitivities:

The occasion was, the miserable estate of the churches in Germany; the calamities upon our native country, the bishops making havock in the churches, putting down the faithful ministers and advancing popish ceremonies and doctrines, the plague raging exceedingly, and famine and sword threatening them; the dangers of those at Connecticut, and of ourselves also, by the Indians; and the dissensions in our churches. ${ }^{141}$

The growth of the English Civil War also contributed to a fever pitch of apocalyptic predictions and beliefs in the colony as well. It is no surprise then that works such as Edward Johnson's Wonder-Working Providence of Sions Saviour both attempted to demonstrate God's providence in planting the English in North America and urged them to keep the faith in the face of the coming apocalypse. ${ }^{142}$ If puritans had reason to fear that the world was coming to an end, then this would have radical consequences on how some of them, most notably John Eliot, approached the natives who continued to associate with the English in the wake of an early history marked by disease, tenuous diplomacy, and warfare.

\section{Evaluating New England's Early History of Contact and Cultural Exchange}

In a study of the interaction of communities in a colonial context, establishing a baseline for these associations and connections is essential groundwork for a more in-depth analysis of the new native communities that formed in close association with English ministers in the 1650s, along with the various concerns that both groups grappled with throughout this period of colonial history. Both puritans and Native Americans held specific ideas about a proper society, its

\footnotetext{
${ }^{141}$ Winthrop, Journal, 208.

142 Johnson, Wonder-Working Providence, 230-36.
} 
function and health, and the place of people within their respective societies, governments, and religious worldviews. Similarly, religious beliefs and practices which shaped ideas about the world's origins, peoples' place within the world, causality in the natural realm, and ritualistic power were inseparable for both communities and merit closer inspection. The native world that English colonists entered was one alive with manitou. Drawing on these sources for trade, healing, warfare, harvest, and communal ritual formed the basis of a healthy and balanced community from the indigenous perspective. The English settlers who came to the region, whether Congregationalist or Separatist, drew on ideas within Calvinistic theology that shaped their own understanding of a properly ordered community, placing special emphasis on the church covenant. Religious ideology served as a powerful shaping force in puritan attempts to create godly communities, and their theological commitments and concerns similarly drove their interactions.

These similar religious frameworks shaped the initial interactions between these societies, determining how each engaged the "other" and integrated them into, or insulated them from, their people. The Massachusetts, Narragansett, and other native communities who first encountered the English sought to draw them in to preexisting trade networks and diplomatic connections to strengthen their own communities. Natives sought to acquire European objects and technological advancements through trade, which they interpreted as powerful manitou. At the same time, this power tempered native trust of the English and contributed to their hesitancy to fully embrace them at times. For the English, understanding and evaluating natives was a chief concern, especially from a biblical framework. In the early years of settling, the English were primarily concerned with issues of food and safety and relied heavily on native forms of diplomacy to keep their neighbors happy and to acquire the goods that they needed to survive. In 
evaluating native society, the English often likened their indigenous neighbors with barbarians of ancient European history. Nearly all colonial leaders acknowledged the potential to reform and shape native culture towards Christianity, even though they did not make substantial efforts to realize the message emblazoned on the Bay Colony seal. At the same time, the recognition of demonic powers at work in the world made Indians a flexible construct in the minds of English colonists, especially when native practices repulsed them or when native communities sought to make war against them.

Moving into the 1640s and 1650s both groups faced challenges to their communities that appeared to threaten solidarity, cohesion, and cosmological correctness and place in the world. The failure of traditional manitou to protect native groups from disease epidemics, to which the English seemed relatively immune, provoked religious introspection and quests in some native communities to cleanse the region of malevolent spiritual forces. The rise of warfare and hostility towards English communities represents one response to this challenge, as does the growing factionalism within native communities and between groups such as the Narragansett and Mohegan in the wake of the Pequot War. While some attempted to purge the English from their proximity, others chose to enter into an even closer association with the English to harness their manitou and build new communities in a dramatically evolving world. The English faced their own internal and external challenges to community solidarity as they confronted behavior that failed to live up to their model society. These activities fueled an early historical myth of puritan degeneration, and provoked challenges to colonial authority from the likes of Thomas Morton, Roger Williams, and Anne Hutchinson. Puritans similarly attempted to ritualistically purge their communities by authoring law codes, banishing offenders, and utilizing capital punishment in the most egregious cases. With the apocalypse looming in the minds of many, it 
was imperative that their community be as godly as possible. In the next chapter we will turn to early Native American efforts to rebuild in the wake of regional upheaval, along with Puritan attempts to establish judicial hegemony over natives who now occupied a subordinate position within colonial society. 


\section{Chapter Two \\ "Not Because I Loved God, But Because I Loved My Brothers": Kinship and the Origins of New England Praying Towns}

The night was alive with the whispers of wind gusts through the leaves and the clamor of nocturnal creatures as Towanquantick slept on his pallet by the flickering light of a fire. Deep in slumber, the Wampanoag sachem from Martha's Vineyard was unaware that he had an unwelcomed visitor, who slowly crept upon him with an arrow strung in his bow and a foreboding sense of determination regarding the task at hand. Stopping a few paces from where Towanquantick lay dozing, he held his breath, drew back his bowstring, and let the chipped broadhead arrow fly at his target. Perhaps the assassin misjudged his distance in the dancing light that penetrated the darkness and cast its shadows on the trees and shrubs around his target, because the arrow missed its killing mark. The arrow hurtled at Towanquantick, gashing his face from the top of the nose to the bottom and skittering across the ground. As Towanquantick jerked up from his sleep and his hands involuntarily covered the wound, he grasped for his dagger with blood-slicked hands. He threw his head wildly about, searching in all directions to spot his assailant, who vanished into the veiled darkness. Running to the safety of a nearby native community to tend his wounds, Towanquantick was amazed that he had the good fortune to escape death despite the fruitless identification or pursuit of his attacker.

Relaying the event to Thomas Mayhew, who recorded the attack in a 1651 report on his missionary progress, Towanquantick claimed that his life had been threatened for "his walking with English.” Adding his own observation to Towanquantick’s, Mayhew also suggested that the attack possibly stemmed from the sachem's forward demeanor at an earlier meeting between Wampanoag sachems and Englishmen. ${ }^{1}$ Though neither Towanquantick nor Mayhew mentioned

\footnotetext{
${ }^{1}$ Thomas Mayhew, Jr., "The Light appearing more and more towards the perfect Day," [1651] in The Eliot Tracts: With Letters from John Eliot to Thomas Thorowgood and Richard Baxter, ed. Michael P. Clark (Westport: Praeger
} 
the following theory, it is also possible that the attack stemmed from an even earlier decision by

Towanquantick to shun the advice of the village powwows and allow Mayhew to bleed his eldest

son, Sachachanimo, as he struggled with a seemingly incurable fever in 1647. After

Sachachanimo successfully recovered, Towanquantick seemed convinced enough by the

powerful manit possessed by Mayhew that he invited Mayhew to come to his people and teach

them, beginning a friendship or close association with Mayhew. While Mayhew was convinced

that Towanquantick and his ilk desired the "word of God," it is more likely that he desired

English medicine and their manit - powerful energy that cured what the traditional manit of the

powwows could not. ${ }^{2}$

This event from a collection of missionary letters commonly referred to as The Eliot

Tracts demonstrates the complexity and violence that often paralleled religious interactions

between native peoples and Protestant missionaries like John Eliot and Thomas Mayhew, Jr. in

New England. ${ }^{3}$ Any number of explanations would suffice, but this story is particularly relevant

in a historical consideration of religious interaction, conversion, and settlement in communities

like Eliot's "Praying Town” of Natick. By the mid-1640s Wampanoag, Nipmuc, and

Publishers, 2003), 180. The title quote for this essay is taken from the confession of Antony (as he was called by English missionaries), in which he describes the nature of his conversion; Ibid., 382.

2 Thomas Mayhew, Jr. "The Glorious Progress of the GOSPEL, amongst the Indians in New England," [1649] in The Eliot Tracts: With Letters from John Eliot to Thomas Thorowgood and Richard Baxter, ed. Michael P. Clark (Westport: Praeger Publishers, 2003), 149-150. Here I use the singular manit in reference to "manitou," which many Algonquian-speaking groups like the Wampanoag considered a powerful manifestation of spiritual power that could take many forms. Neil Salisbury, Manitou and Providence: Indians, Europeans, and the Making of New England, 1500-1643 (Oxford: Oxford University Press, 1982), 37-39. I have dramatized or stylized the introductory narrative in comparison to the relatively dry, matter-of-fact reporting by Mayhew in his portion of the tract in order to better imagine how Towanquantick was wounded in the particular manner and circumstance described in Mayhew's account. I trust that this bit of rhetorical license serves to draw out the human implications of colonial interaction. It is also possible that Towanquantick knew his attacker and received the facial wound in a more direct confrontation, yet he was unwilling to provoke further enmity between the English and his fellow tribesman. Regardless of the context, community and interpersonal relations remain at the heart of this event.

${ }^{3}$ Though they are called The Eliot Tracts, Eliot himself often played a peripheral role in their production when compared to the editors who facilitated their publication and distribution. Nevertheless, they are an important source for uncovering missionary interaction in New England before Metacom's War. Michael P. Clark, "Introduction," in The Eliot Tracts: With Letters from John Eliot to Thomas Thorowgood and Richard Baxter, ed. Michael P. Clark (Westport: Praeger Publishers, 2003), 1. 
Massachusetts communities surveyed a tumultuous landscape: disease epidemics wracked families and loved ones, their new neighbors acted with astonishing brutality in the recent Pequot war, and the English seemingly possessed strong manit which protected them from the same diseases and allowed them to expand atop native settlements. By this point some considered engaging the English in new ways as a means of continuance. The difficult decision to adopt certain aspects of English culture, or to forsake traditional religious practices managed by village powwows, resulted in factionalism and division within families, inside communities, and between allied native polities. For natives who chose to convert, mending the tear that then existed in village harmony was crucial to survival and the maintenance of a healthy community. At the same time, interested natives recognized the benefits that ministers and governors could serve as powerful allies and advocates, especially in the colonial court system. Religiously, the apocalyptic eschatology possessed by Eliot and his ilk provided a triumphal vision for their future in service of a loving and forgiving deity and a powerful explanation for the fate which had befallen native populations in New England.

Navigating this changing world involved a dance between traditional and foreign cultures, with their embedded political, religious, and social connections, and confronting European expectations that often included cultural conformity. Recognition of the duality of existence for "converts" and the complications that arose from affecting a liminal stance in both worlds enriches the study of cultural interaction in colonial North America. Bringing religious belief and practice to the forefront also fosters a better understanding of native decision-making and engagement with missionaries and Christianity. By studying the familial drama of conversion and the efforts natives undertook to reestablish communities in a new religious context, analysis of Natick and Martha's Vineyard origins provide a new interpretation on 
English colonization that restores decision-making to Native American individuals and families and develops new implications for missionary communities that emphasize forethought and the desire to rebuild in the wake of tragic social and communal disruption.

At the same time, the impetus for English interactions in a specifically missional context developed in light of transatlantic news of revolution and regicide, which resonated conceptually within the latent apocalypticism of puritan thought. For puritan ministers such as John Eliot, a millennial eschatology predicting the end of the world and the beginning of Christ's new kingdom on earth served as a powerful motivation to convert Native American "gentiles," opening up a new form of religious space where English leaders could seriously engage with interested Native Americans and confront their biases of cultural superiority and native barbarism. More often than not it proved to be trained ministers and colonial leaders who served the missionary projects in various capacities and wrestled with their role as cultural and social intermediaries between native and English worlds. Those most intimately involved in the project were forced to consider difficult questions: What changes are necessary for conversion? What aspects of native culture did not pose a challenge to Christian thought and practice? What would a native church look like, and how should their leaders govern? What relationship existed between Indian Christian polities and the larger commonwealth as natives in praying communities affirmed English hegemony? Those involved in missionary projects also faced the larger English community in New England and faced the nature and problems of English suspicion towards Native Americans in general. The Pequot defeat in 1638 ensured that the most immediate hostility and suspicion toward Native Americans subsided, enabling missionaries to establish nascent Praying Towns during the interim amidst simmering unease and distrust. The 
resumption of tension on the eve of King Philip's War in the 1660s put missionaries in a somewhat dangerous position of advocating for potential enemies to the commonwealth.

This chapter begins with a brief exploration of English hegemony and missions in colonial North American historiography to establish the current state of the field on questions of “conversion," English rule, the role of missionaries, and cultural imperialism, bringing the study of puritan theology to the forefront of these debates. The chapter then considers millenarian thought in puritanism and the role of the English Civil War in leading many ministers to seriously consider the urgency and viability of a missionary project among their Native American neighbors. Apocalypticism importantly opened a conceptual religious space which welcomed Native Americans and invited them to enter into a religious and cultural dialogue. Missions also operated within a transatlantic space forged by the correspondence between missionaries, colonial leaders, and English supporters of the project. After exploring the theological and social forces which encouraged English engagement as missionaries, the chapter then examines the native perspective and response to this new form of cultural interaction. It considers the scope of native losses in the wake of disease epidemic, wartime dislocations, and English territorial encroachment in light of the potential benefits which natives derived from a closer partnership or affiliation with the English. The gains that stood to be made from reorganization and the adoption of an Indian Christian identity included territorial recognition, trading benefits, political and social allies and advocacy, and a cosmological narrative explaining the nature of native losses and a vision for the future. At the same time, this section takes serious the challenges that "conversion" posed to existing kinship networks and community dynamics that challenged the authority of sachems and powwows. Finally, the chapter examines the social 
and religious history of the early missionary communities as natives and English missionaries

worked out the detail of authority and practice in these new polities.

\section{Colonization, Conquest, and Missions in Colonial Historiography}

The earliest examinations of colonial missionary projects such as Eliot's Praying Towns

were largely contained within missionary hagiography and Protestant religious history and sought to emphasize the piety of missionaries and their successes. These works considered missionaries in a largely unbiased light, casting the blame for their supposed failures on natives, who bore "savage" or "uncivilized" stigmas. ${ }^{4}$ Modern religious historians have shed this particular hagiographic bias and transitioned from the study of purely orthodox religion and religious leaders and missionaries to exploring popular beliefs, folklore, and witchcraft that often appeared eerily similar to native practices from the perspective of worried ministers. ${ }^{5}$ These historians also recognize the multiplicity of religious beliefs and experiences in the colonial

\footnotetext{
${ }^{4}$ Martin Moore, Memoirs of the Life and Character of Rev. John Eliot, Apostle of the N.A. Indians (Boston: T. Bedlington, 1822), 162-3. In the preface to his work, Moore wrote that the intent of the work was to highlight Eliot's exceptional character as a missionary to "encourage exertions [by his contemporaries] to civilize and evangelize the tribes" west of established settlement (iii-iv). Similarly, the introduction to one of Eleazar Wheelock's early biographies highlights this aspect of hagiography, stating that he developed a spirit to "spread the gospel among the heathen," and that "the darkest abodes of superstition and idolatry are enlightened by the beams of gospel grace." McClure and Parish's biography of Wheelock is especially indicative of early nineteenth century ethnography, as they highlight various "savage" qualities that hinder native conversion (as opposed to failures of European culture) and denigrate the "profane and heathenish lives of nominal Christians, who traffic with them or live on their borders [to take advantage of them with "ardent spirits"]." David McClure and Elijah Parish, Memoirs of the Rev. Eleazar Wheelock, D.D. [1811] (New York: Arno Press, 1972), v, 100-106. These works also ignore questions of native perspective, religion, or autonomy in favor of determining whether or not conversion was "genuine." Similarly, success for missionaries in these accounts often took the form of a numerical register of natives baptized or a census of those living within the various Praying communities like Natick, while failures or negative emphases tended to revolve around charges of apathy in the colonial population towards the missionary projects or a desire to undermine them through the peddling of alcohol. Furthermore, conversion is described or defined as an inner, personal decision to commit oneself to a belief in Jesus Christ, so analysis of conversion has tended to favor the Protestant understanding of religious experience with little regard to the communal mindset of many native groups in New England. Memory and the New England missionary projects is a topic covered in greater depth in a later chapter, though it is worth mentioning these early accounts of the missions here.

${ }^{5}$ David D. Hall poignantly states that "religion was embedded in the fabric of everyday life," arguing that popular folk beliefs flourished in colonial New England despite the efforts of orthodox leaders to suppress them. David D. Hall, Worlds of Wonder, Days of Judgment: Popular Religious Belief in Early New England (Cambridge: Harvard University Press, 1989), 3-5. See also Jon Butler, Awash in a Sea of Faith: Christianizing the American People (Cambridge: Harvard University Press, 1990).
} 
world, suggesting that traditional practices and beliefs were adapted to the various religious sects imposed by European colonizers. ${ }^{6}$ In the case of puritan New England, this has signaled the rejection of Perry Miller's monolithic "New England Mind” in favor of a more nuanced, complicated, and at times heterodox understanding of the varieties of puritanism. Likewise, historians have traditionally portrayed natives as an impediment to the aegis of European “civilization" or "progress," serving as a savage component to North America that threatened the political and economic success of early colonial ventures. New perspectives within imperial history that consider the subaltern, the complications of colonization as a process, and the darker effects of imperialism on oppressed groups have rightly dismantled this consensus perspective, while simultaneously casting English missionaries as agents of cultural imperialism intent on destroying all aspects of native culture. ${ }^{7}$ The use of archaeological findings and anthropological methods has also demonstrated the existence of native histories and culture before the creation of a European written record, offering a counterpoint of a native perspective to colonization, considering questions of survivability, resistance, and cultural adaptation in an increasingly

\footnotetext{
${ }^{6}$ Jon Butler, New World Faiths: Religion in Colonial America (Oxford: Oxford University Press, 2008), 92-107. Douglas L. Winiarski has also broadly examined a number of popular native beliefs pertaining to family, literacy, healing and mortuary customs, and supernatural lore over the period of 1670-1770, suggesting that native practices closely mirrored the folk beliefs of common English settlers. Douglas L. Winiarski, "Native American Popular Religion in New England's Old Colony, 1670-1770" Religion and American Culture: A Journal of Interpretation 15 (2005): 148-49. What formed in Praying Towns like Natick was assuredly a syncretic faith that was neither fully "Christian" nor fully "Native" according to this vein of scholarship.

${ }^{7}$ The quintessential introduction to the notion of the "Other" as conceptualized by Western civilization remains Edward Said's Orientalism, though his critique of cultural, historical, and political ethnocentrism certainly is applicable within the study of colonialism in North America. Tzvetan Todorov has similarly applied this notion of East-West conflict to the conquest of the Aztec, noting that the destruction of Aztec religious books and civic monuments served to undermine their identity in a conquest of knowledge, subjecting the Aztec within a Western thought-system. Tzvetan Todorov, The Conquest of America: The Question of the Other, trans. Richard Howard (Norman: University of Oklahoma Press, 1984), 60, 254. Patricia Seed has also examined the cultural ambiguities and foibles of colonization through an examination of the processes various European cultures attempted to establish political hegemony in North America Patricia Seed, Ceremonies of Possession in Europe's Conquest of the New World, 1492-1640 (Cambridge: Cambridge University Press, 1995), 3. All of these examples demonstrate the shift in historical interpretation recasting imperialism as complicated and culturally contingent. This serves as a balancing mechanism for the introduction of native perspectives and action, discussed further in the historiographic section of this essay.
} 
destructive world subjected to European hegemony. ${ }^{8}$ Despite this tremendous shift in

perspective, the earliest works which comprise the corpus of "New Indian History" often

consider cross-cultural encounters as a primal form of conflict, and disparage Native Americans

who engaged or embraced aspects of European life as traitors to their culture and people.

Recent works in Native American history represent a methodological or conceptual shift

that provides room for cultural accommodation in various arenas. Richard White's study of

native refugee communities in the politically ambiguous "shatter zone" of the pays d'en haut

emphasizes the hybridization of cultures that occurs in communities made up of displaced

peoples from various localities and lineages. ${ }^{9}$ Other works have similarly emphasized the

cultural similarities between native groups and Europeans, eschewing earlier ethnohistorical

models that perceive an insurmountable chasm between two cultures set in opposition. ${ }^{10}$

\footnotetext{
${ }^{8}$ Within Canadian history, Bruce Graham Trigger has offered the greatest critique of the country's "Heroic Age", as well as Jesuit missions, portraying colonialism in this context as underhanded. For Trigger, conversion and adaptation by native groups like the Huron was purely politically and socially motivated. Bruce G. Trigger, Natives and Newcomers: Canada's "Heroic Age" Reconsidered. (Montreal: McGill-Queen's University Press, 1985), 5-9, 254-59. Similarly, Neal Salisbury has given natives and Europeans equal treatment in the story of New England's colonization, eschewing the notion that conquest was inevitable, though his narrative ends before the creation of praying towns. Salisbury, Manitou and Providence, 3-12. James Axtell has also broadly examined colonization in New England and Canada from the perspective of the English, French, and Natives of the region, arguing that natives possessed ample resources to resist colonization and that aspects of their lifestyles were actually preferable to some Europeans. James Axtell, The Invasion Within: The Contest of Cultures in Colonial North America (New York: Oxford University Press, 1985), 3-6. More detailed considerations of Praying Towns within this historiographic school also emphasize the failure of the missions as part of a "cultural chasm between the two races [excluding] the praying Indians from any real participation in the English communities." Kenneth M. Morrison, “"That Art of Coyning Christians:' John Eliot and the Praying Indians of Massachusetts” Ethnohistory 21 (1974): 79. Norman Earl Tanis has also examined education in Eliot's Praying Towns, highlighting the rigid social control that characterized the structure of Praying Town governance. The goal of the mission then was to enact full conversion, "making the Indians as much like their Puritan neighbors as was possible." Norman Earl Tanis, "Education in John Eliot's Indian Utopias, 1646-1675" History of Education Quarterly 10 (1970): 308. In summary, ethnohistory's methodology and outlook neglect the presence of cultural hybridity and nuanced interaction in favor of denigrating the European perspective and natives who adopted Europeanized practices, suggesting that they had betrayed tradition and culture.

${ }^{9}$ Richard White, The Middle Ground: Indians, Empires, and Republics in the Great Lakes Region, 1650-1815. Twentieth Anniversary Edition (New York: Cambridge University Press, 2011), xi-xiv. Aspects of White's conclusions, particularly the cultural nature of survivability and the process of middle ground formation, apply to earlier communities and locations like Natick and Brothertown.

${ }^{10}$ Working with the cultural conceptions of warfare and masculinity, Ann M. Little suggests that the two groups had far more in common in these particular arenas than previous historians have recognized, suggesting instead that polemical differences were employed by both groups to emphasize their cultural superiority as a means of
} 
Likewise, this research centers on natives who chose to "convert" (a potentially loaded term which I use acknowledging the range of things that this could mean from an indigenous perspective) and elucidates the struggle to exist in two worlds, meeting the expectations of English missionaries while simultaneously maintaining connections to fellow villagers and other tribes that adhered to traditional beliefs and practices. Much of the tension between these two worlds converged at the nexus of family and kinship ties. Adopting this perspective provides a counterpoint to earlier critiques of missionary work and native conversion in favor of a complex, dynamic study of community relations that eschews judgment of either group. Informing this research is the notion of cultural translation and augmentation where natives are concerned, and consideration of religious conversion from the perspective of community, giving credence to the emphases natives placed on particular Christian beliefs over others. While English missionaries like Eliot certainly denigrated aspects of native culture and were imperialists in the sense that they refused to budge on certain points of cultural change, the collaborative nature of missions which derived from linguistic and cultural barriers ensured that native leadership and preaching were unavoidable, forcing missionaries to afford native missionaries and ministers a relatively autonomous and powerful leadership role in shaping indigenous religious practices. ${ }^{11}$ This forced

empowerment. Anne M. Little, Abraham in Arms: War and Gender in Colonial New England (Philadelphia: University of Pennsylvania Press, 2007), 2-5. Joshua David Bellin asserts that the missions were a site of cultural performance where "the 'real' Indian emerge by 'feigning' puritanism, while the 'real' puritan emerged by 'feigning' Indianness. . however John Eliot may have sought to control Indian play, he ended up playing Indian." Joshua David Bellin, “John Eliot's Playing Indian” Early American Literature 42 (2007): 2. Historians Robert James Naeher, J. Patrick Cesarini, and David J. Silverman have explored Puritan theology and native confessions, as recorded by missionaries, to determine theological concepts that were meaningful and adapted by natives in the missions. Robert James Naeher, "Dialogue in the Wilderness: John Eliot and the Indian Exploration of Puritanism as a Source of Meaning, Comfort, and Ethnic Survival” The New England Quarterly 62 (1989): 347. J. Patrick Cesarini, "John Eliot's 'A Breif History of the Mashepog Indians,' 1666” The William and Mary Quarterly 65 (2008): 104. David J. Silverman, “The Curse of God: An Idea and Its Origins among the Indians of New York's Revolutionary Frontier" The William and Mary Quarterly 66 (2009): 497-99. David J. Silverman, "Indians, Missionaries, and Religious Translation: Creating Wampanoag Christianity in Seventeenth-Century Martha's Vineyard" The William and Mary Quarterly 62 (2005): 144-46.

${ }^{11}$ Edward E. Andrews, Native Apostles: Black and Indian Missionaries in the British Atlantic World (Cambridge: Harvard University Press, 2013), 4-11. 
New England puritans to grapple with the conceptual notion of indigenous churches and

communicants within the network of colonial congregationalism and ministers.

Eliot, Mayhew, and the Praying Towns of Natick and Martha's Vineyard traditionally fall within the earlier colonial historiography detailing the conquest and settlement of New England. Subsequently, they are the bookend to a narrative of English ascendency and native loss. ${ }^{12}$ This dissertation as a whole seeks to free the study of Indian Christians from a narrative arc that places their formation at the end of a story of conquest and declension. It is worth noting that this was also a beginning. By focusing on beginnings and the origin of unique religious and political communities I hope to provide a glimpse at the process of communal conversion and religious cultural interaction from both an English and indigenous perspective. This research considers both of these specific missionary contexts from the perspective of individuals who felt the pull of tradition, family, community, and English missionaries, and questions the role that family and kin played in conversion. It also explores how natives in both contexts envisioned conversion and the adaptation of certain practices or beliefs as a vehicle for building a successful, if not survivable, future. At the same time, nuanced changes in puritan theology which developed in a tenuous colonial context, served as bridges and barriers which facilitated or deterred meaningful cultural interaction between Native Americans and English missionaries.

\footnotetext{
${ }^{12}$ Salisbury, Manitou and Providence, 236. Salisbury contends that the capture of Miantonomi in 1643 represented "a critical historical divide" in New England's history. It is also telling that his monograph avoids the creation of Praying Towns altogether with the abrupt ending in 1643, conveniently before six sachems submitted themselves to the Massachusetts General Court in 1644. Richard W. Cogley, John Eliot's Mission to the Indians before King Philip's War (Cambridge: Harvard University Press, 1999), 22. In an article specifically devoted to Praying Towns, Salisbury again highlights the cultural gap between natives and missionaries, contending that English dominance was only asserted when hegemony was present (post-1643) and that missionaries were simply agents of colonialism. Neal Salisbury, "Red Puritans: The 'Praying Indians' of Massachusetts Bay and John Eliot" The William and Mary Quarterly 31 (1974): 28-31. Richard W. Cogley has written on Eliot and the missions, but with a principal emphasis on Puritan theology and how this drove the missions. Cogley, John Eliot's Mission, 5-18. James Axtell also casts a decidedly negative perspective on the missions, emphasizing the loss of traditional sachem authority and the strict control of the missionaries as an example of the only successful theocracy in the colonies. Axtell, The Invasion Within, 141-42. Francis Jennings also considers the missions a product of political expediency, and paints Eliot as an opportunist who took credit for Mayhew's work. Francis Jennings, "Goals and Functions of Puritan Missions to the Indians" Ethnohistory 18 (1971): 203, 208.
} 


\section{The English Civil War, Apocalypticism, and New England Missions}

Any consideration of puritan motivations for indigenous missions and the theology which shaped English missionary action must first consider the context in which this impulse developed. The English Civil War proved to be a disruptive event that resonated across the Atlantic and affected puritans already consumed with founding a godly community in North America. Interpreting Commonwealth developments through the framework of an imminently apocalyptic eschatology led missionaries like Eliot and Mayhew to launch efforts to convert Native Americans to Christianity under the assumption that they were fulfilling scriptural prophecies that the gospel would reach all of the gentiles throughout the world. This vision traveled across the Atlantic where Parliament, recently emboldened and radicalized with the execution of Charles I, chartered a transatlantic missionary project to further aid developments in New England. In the tumult of religious and civil reform under Oliver Cromwell, New England luminaries such as John Cotton authored The Keys of the Kingdom of Heaven (1644) as a defense of the New England Way, followed by The Way of Congregational Churches Cleared (1648), as an extended defense of Congregationalist practices. John Eliot similarly offered a vision for a sacred polity modeled on Natick and the early Praying Towns in The Christian Commonwealth (1659), linking eschatology, missions, civil war, and reform. ${ }^{13}$ As New England missionaries secured funding and support for their efforts amidst the Massachusetts and Wampanoag, they also grappled with and conceptualized the nature and purpose of missions, as well as the relationship between themselves and native ministers, and between indigenous communities and

\footnotetext{
${ }^{13}$ Ralph F. Young, "Breathing the 'Free Aire of the New World': The Influence of the New England Way on the Gathering of Congregational Churches in Old England, 1640-1660," The New England Quarterly 83 (2010), 5, 19, 22. Linda Gregerson argues that the turbulence of the English Civil War fostered a desire "to achieve an interim consolation, that of community. With no guarantee that they would constitute the community of the saved, the agents of the Christian mission could perform the work that marked them as the community of the hopeful." Linda Gregerson, "The Commonwealth of the Word: New England, Old England, and the Praying Indians," in Empires of God: Religious Encounters in the Early Modern Atlantic, ed. Linda Gregerson and Susan Juster (Philadelphia: University of Pennsylvania Press, 2011), 82.
} 
colonial authorities. Equally worthwhile to consider in the early idea of missions is the reality of the shifting power dynamics within the colony as groups like the Massachusett and Nipmuc confronted the growth of colonial power, which emboldened leaders to pass new laws regulating the activities and actions of Native Americans over which the English claimed governance. Puritanism held at its core an urgent sense of immediacy in matters of ecclesiastical reform and social behavior. The most zealous proponents of the original Anglican reforms under Henry VIII created puritanism as a distinct identity and set of theological positions that coexisted at great tension within the Anglican Church as a whole, leading many to participate in the Great Migration of the 1630s and populating New England in the process. ${ }^{14}$ In their reforms early puritans remained convinced that they were restoring the Church to its original formulation and doctrine, as found in the initial religious communities forged by Jesus's disciples and the Apostle Paul. ${ }^{15}$ This militancy, at times equally projected on Catholic and Anglican opponents to puritan reform, naturally grew out of the Calvinistic formulation of God as a wrathful and stern Sovereign who had revealed to John in Revelations the nature and breadth of his destructive and apocalyptic return. ${ }^{16}$ Puritan ministers on either side of the Atlantic read heavily across the spectrum of Christian writers from antiquity through the Reformation, giving primacy to the Bible, so it comes as no great surprise that apocalyptic thought was present early on in New England ministers like John Eliot or dissenter Roger Williams.

\footnotetext{
${ }^{14}$ Bremer, The Puritan Experiment, 15-16.

15 Theodore Dwight Bozeman, To Live Ancient Lives: The Primitivist Dimension in Puritanism (Chapel Hill: University of North Carolina Press, 1988), 13-23. Bozeman contends that "while defenders of the established church busied themselves qualifying and supplementing biblical authority, Puritan thinkers moved into an ever more resolute Biblicism with special focus upon the archetypes of the Great Time." (42) Eliot's societal model outlined in The Christian Commonwealth clearly reflects this primitivist dimension of Puritanism within the context of missions.

${ }^{16}$ David D. Hall, A Reforming People, 15. Bremer, The Puritan Experiment, 27. W. Clark Gilpin, The Millenarian Piety of Roger Williams (Chicago: University of Chicago Press, 1979), 2-4. Henry M. Knapp highlights the Puritan understanding of two mass conversions of eschatological significance for both Jews and Gentiles. Regardless of how Europeans conceptually categorized Native Americans, they potentially fell into one category or the other. Henry M. Knapp, "The Character of Puritan Missions: The Motivation, Methodology, and Effectiveness of the Puritan Evangelization of the Native Americans in New England," The Journal of Presbyterian History 76 (1998), 115.
} 
There is some debate historiographically whether John Eliot initially began his efforts to convert members of nearby Massachusetts and Nipmuc communities in response to the isolation of the New England colony and its peripheral role in the ensuing Civil War or if missions were a natural outpouring of Eliot's millenarianism and his appropriation of eschatological tropes regarding the conversion of Gentiles in Revelation. ${ }^{17}$ Regardless of the debate surrounding Eliot's motivation, it is clear that his radical millenarianism shaped the ways in which Eliot engaged Native Americans and how he presented his work to a wider transatlantic audience. In the collection of Eliot letters compiled as a 1651 pamphlet entitled Strength out of Weaknesse, Eliot lauded the progress of his converts in formally affirming a covenant "unto God to be his people," and joining "themselves into the Government of God" as a first step "to prepare them for Church-estate."18 Eliot's millennial understanding of the relationship between civil and ecclesiastical rule is apparent in The Christian Commonwealth (1659), in which he writes:

the Lord Jesus will bring down all people, to be ruled by the Institutions, Laws, and Directions of the Word of God; not only in Church-Government and Administrations, but also in the Government and Administration of all affairs in the Commonwealth. And then Christ reigneth, when all things among men, are done by the direction of the word of his mouth: his Kingdom is then come amongst us, when his will is done on earth, as it is done in heaven. ${ }^{19}$

\footnotetext{
${ }^{17}$ Carla Gardina Pestana asserts that Eliot's missions were primarily a means of containing Gortonist advancements with local natives and as a way to "rehabilitate the colony's reputation in England." Carla Gardina Pestana, The English Atlantic in an Age of Revolution, 1640-1661, 11, 79. Conversely, James Holstun has argued that Eliot's project at Natick and his subsequent text on religious polity entitled The Christian Commonwealth are best understood in the vein of utopian thought and a commitment to urgent reform in the face of the coming apocalypse. James Holstun, “John Eliot's Empirical Millenarianism," Representations 4 (1983), 130, 136. Eliot's most recent eminent biography, Richard W. Cogley, has authored the most comprehensive examination of Eliot's progression of thought from his initial understanding of the eschatological significance of the English Civil War through the Restoration. According to Cogley, Eliot understood Indian conversion and their transition to "visible sainthood" to be a necessary step towards the fulfilment of biblical prophecy. Richard W. Cogley, "John Eliot and the Millennium," Religion and American Culture: A Journal of Interpretation 1 (1991), 228-30.

${ }^{18}$ Clark, ed., The Eliot Tracts, 226-27.

${ }^{19}$ John Eliot, The Christian Commonwealth: Or, The Civil Policy of The Rising Kingdom of Jesus Christ (London, 1659), iii.
} 
As Eliot maintained correspondence with puritans in England, developments in Natick and interested indigenous communities shaped his understanding of contemporary English events and their place within biblical eschatology.

Roger Williams serves as a constructive counterpoint to Eliot to demonstrate the subjective spectrum of apocalyptic thought and a divergent view of Native Americans within biblical eschatology. W. Clark Gilpin argues that it was Williams' fear of God's judgment that pushed him towards a stricter separatist position, as the severance of apostolic succession meant that no contemporary church was authentic; only with Christ's millennial return would the true church be reconstituted under new apostolic headship. ${ }^{20}$ Though Williams remained a staunch advocate of amicable relations with Native Americans in Rhode Island, his earlier interest in indigenous conversion was tempered by more pragmatic and material concerns under the conviction that native conversion did not truly fit apocalyptic eschatology, a position he expanded in the 1645 tract Christenings Make Not Christians and his pamphlet debates with John Cotton. ${ }^{21}$ Williams questioned whether the recent New England conversion represented "the times of ignorance (which God pleaseth to passe by) are over, and now a greater light concerning the Church, Ministry, and conversion, is arisen." In this polemic, Williams argued that recent acclaim for conversions in New England was no different from false conversions conducted by Catholic missionaries, citing the ninth chapter of Daniel as an eschatological defense for his contrarian position. ${ }^{22}$ Despite Williams' general divergence from mainstream

${ }^{20}$ Gilpin, Millenarian Piety of Roger Williams, 54-57.

${ }^{21}$ Ibid., 116-21.

${ }^{22}$ Roger Williams, Christenings Make Not Christians (1645), in Rhode Island Historical Tracts No. 14, Henry Martyn Dexter, ed. (Providence: Sidney S. Rider, 1881), 13-14, 16-21. Daniel 9 consists of a supplication to God for the sins of Israel in verses 1-20, and then a prophetic pronouncement in verses 21-27 of a seventy week period in which Israel is "to finish the wickedness, and to seal up the sins, and to reconcile the iniquity, and to bring in everlasting righteousness, and to seal up the vision and prophecy, and to anoint the most Holy." Reading this prophecy for its contemporary significance, Williams certainly recognized that English ecclesiastical factionalism meant that this was not yet fulfilled. 
eschatological thought in both New and Old England, his rejection of an indigenous

eschatological role demonstrates his sustained efforts to interpret the world around him and the place of various actors in God's apocalyptic tableaux. Millenarianism thus proves to be a flexible theological component which could lead individuals to adopt unexpected positions. Similar thinking and flexibility would shape English concerns in the 1640s as the country lurched closer towards sectarian violence.

Considerations of the origins and nature of a particular war or conflict often produce multivalent and competing interpretations regarding causality, though the English Civil War is somewhat unique in the relative historiographical agreement on the importance resistance to high church impositions by Charles I and Bishop Laud played in triggering the Scottish revolt and Parliamentary schisms. ${ }^{23}$ Nicholas Tyacke has demonstrated that a puritan political faction existed in England as early as Mary I's reign and that the notion of a sudden "Puritan Revolution" ignores concerted attempts by English puritans to shape succession after the death of Elizabeth and Charles I's marriage decision, among other political goals. ${ }^{24}$ If religious opposition had always existed as an undercurrent within English political culture, especially as monarchs following Henry VIII vacillated on the form and substance of ecclesiology, the heavyhandedness of Laudian censorship of puritans resonated with a growing apocalyptic urgency

\footnotetext{
${ }^{23}$ Richard S. Dunn, The Age of Religious Wars, 1559-1715, $2^{\text {nd }}$ Edition. (New York: W.W. Norton \& Company, 1979), 164-172. In "The Religious Context of the English Civil War," John Morrill has observed that civil and religious issues and motivations of those involved in the war were at times mutually exclusive, as "many notable puritans paid ship money without protest, and some were even effective ship money sheriffs; many notable protesters against secular misgovernment proved to be loyal defenders of the established church in 1641-2." Over the course of this essay Morrill continually highlights the slow development of a political case against Charles I, contrasting these developments with the "stark contrast" of religious accusations against the monarch. John Morrill, "The Religious Context of the English Civil War," Transactions of the Royal Historical Society 34 (1984), 157, 162. In a recent historiographic sketch of the war, Charles W.A. Prior reaffirms the importance of the imperial connection, especially in light of overseas experimentation with polity reform in New England and the spirit of competition colonization engendered between Britain and its Catholic rivals, Spain and France. Charles W.A. Prior, "Religion, Political Thought and the English Civil War," History Compass 11 (2013), 31.

${ }^{24}$ Nicholas Tyacke, "The Puritan Paradigm of English Politics, 1558-1642," The Historical Journal 53 (2010), 527, $537,541$.
} 
possessed by many. ${ }^{25}$ For the purpose of this paper, the importance of prophecy and apocalyptic thought as a "clarion call to the nation" echoed across the Atlantic and led puritans in England and North America to interpret the context of their lives through biblical prophecy. As a result, Native Americans, Scottish Highlanders, New Model Army soldiers, and ministers in both countries stood at the threshold of dramatic changes promulgated by the will of almighty God in the minds of many puritans. ${ }^{26}$

Literate Englishmen had long been interested in prophetic pronouncements, avidly consuming texts like the Sibylline Oracles and prophecies attributed to King Arthur's court magician Merlin. ${ }^{27}$ As the sixteenth century unfolded and religious schism rent the political fabric of Europe, prophecies specifically focused on the Book of Revelation and the end of the world enjoyed a new sense of urgency as Europeans interpreted contemporary events through the lens of biblical eschatology. The quintessential example of an English prophetic voice promulgated through extensive pamphleteering was that of Thomas Brightman, whose commentaries on Revelation, Song of Songs, and Daniel enjoyed extensive circulation in various forms after his death in 1607 and were revived in earnest as England hurtled towards civil war. ${ }^{28}$

\footnotetext{
${ }^{25}$ Dunn, Age of Religious Wars, 169-70.

${ }^{26}$ Crawford Gribben has written on the eschatological role of Scotland during the course of the Civil War, highlighting the eventual shift in thought which came to demonize the Scots as Parliament and Presbyters clashed during the Protectorate, which is worthwhile to consider in light of the flexible tropes provided by Puritan eschatology in general. This same flexibility would prove to be problematic in placing Native Americans within a religious framework, as the previous chapter demonstrated and subsequent chapters will reinforce. Crawford Gribben, "The Church of Scotland and the English Apocalyptic Imagination, 1630 to 1650," The Scottish Historical Review 88 (2009), 35-36, 40. Roger Williams obviously excluded natives from his eschatological musings, though he would not be the last New Englander to employ a flexible theology which negatively stigmatized Native Americans.

${ }^{27}$ Gilpin, Millenarian Piety of Roger Williams, 8-9.

${ }^{28}$ Andrew Crome notes that Brightman's writings proved popular to a continental audience during his lifetime, but were "known by a number of preachers in England from 1611 onwards," enjoying their most extensive circulation after 1644. Andrew Crome, "Constructing the Political Prophet in 1640s England," Seventeenth Century 26 (2011), 280. Jason Peacey notes that literary culture during the war also resulted in a growing curiosity with the workings of Parliament, especially for "lobbyists" (including English puritans) who sought to shape various reforms under Cromwell. Jason Peacey, "Print Culture and Political Lobbying during the English Civil War," Parliamentary History 26 (2007) , 30, 46. Gilpin also cites the importance of Thomas Brightman and Joseph Mede as oracles in the feverish religious politics of the 1640s. Gilpin, Millenarian Piety of Roger Williams, 12.
} 
Brightman's A Revelation of the Revelation that is...The Revelation of St. John opened clearly with a logicall Resolution and Exposition opens with an exhortation to the European churches to remain firm amidst religious strife and places historical events within the opening of scrolls and seals in the Book of Revelation, and arguing against the popular Protestant conceptualization of the Pope as Antichrist. ${ }^{29}$ Brightman's prophecies enjoyed new life amidst the collapse of print censorship in revolutionary England and were widely circulated and dissected into pamphletlength vignettes with additional commentary throughout the early war. The 1641 pamphlet $A$ Revelation of Mr. Brightmans' Revelation consists of a fictional conversation between an English minister and an anonymous citizen over the accuracy of Brightman's prophecies concerning Germany, Scotland and England forty years before the events occurred. ${ }^{30}$ If Brightman served as the prophetic voice of this revolutionary generation, his emphasis on the restoration of the Jews resonated with news in 1648 that New England puritans had made the first great strides in converting Native Americans to English Christianity, adding further credence to his apparent gift for prophecy.

Convinced that the early results of Eliot and Mayhew popularized in Thomas Shepard's The Clear Sun-Shining of the Gospel breaking forth upon the Indians in New-England (1648) represented the beginning of widespread conversions for Native Americans in New England, which was itself a fulfilment of eschatological significance in the vein of Brightman's popular prophecies, the puritan-dominated Parliament authorized the creation of a transatlantic fundraising and missionary project in July 1649 , just months after the trial and execution of Charles Stuart. Citing the early progress of the New England missionaries in convincing some

\footnotetext{
${ }^{29}$ Thomas Brightman, A Revelation of the Revelation that is... The Revelation of St. John opened clearly with a logicall Resolution and Exposition (Amsterdam, 1615), 622-656.

${ }^{30}$ Crome, "Constructing the Political Prophet," 281-85. A Revelation of Mr. Brightmans' Revelation, Wherein Is shewed, how all that which Mr. Brightman on the Revelation, hath fore-told concerning Germany, Scotland, and England, hath beene fulfilled, and is yet a ful-filling, comparing his writings, and our Times together (1641), 1-3.
} 
natives to repent of their "satanical delusions," along with the success of catechesis among native children, the parliamentary tract emphasized that these early achievements required an even greater commitment from the English in the colony and greater Commonwealth along with the creation of schools and universities to properly educate Native Americans. ${ }^{31}$ To further this project, Parliament authorized the creation of an English branch of the Company for Propagating the Gospel in New England and Parts Adjacent in North America (CPG) consisting of sixteen members, including a president and treasurer, to supervise fundraising efforts to sustain the colonial missionary project. Thus, the division of labor ensured that the English branch would focus primarily on fundraising while colonial members of the CPG would be entrusted with spending the funds that were raised by a general collection throughout English and Welsh towns and communities. The pamphlet publicizing the origins of the CPG also called on English ministers to cheerfully exhort their parishioners towards donating money to the cause, highlighting the difficulty their colonial cousins faced in building settlements within a "desolate wilderness. ${ }^{\circledR 2}$ In response to this exhortation, ministers at Oxford and Cambridge developed and published broadsides in order to carry out Parliament's desire for their cooperation and assistance. The Cambridge broadside similarly recognized the early work of Eliot and Mayhew and the benefit this project provided to God's kingdom in explicitly apocalyptic language: "Arise O God, judge the earth, for thou shalt inherit all nations." The broadside similarly stresses the potential judgment of God in his return and the necessity for Englishmen to do their part in supporting the English missions, especially with the recent advancements made by Catholic

\footnotetext{
${ }^{31}$ Pamphlet, "An Act For the promoting and propagating the Gospel of Jesus Christ in New England," (London: Edward Husband, 27 July 1649," DA27-L, Massachusetts Historical Society (hereafter abbreviated "MHS"), 407408.

${ }^{32}$ Ibid., 408-412.
} 
Jesuits. ${ }^{33}$ Both the parliamentary pamphlet and the university broadsides circulated widely and reached English parishioners in an effort to hasten their urgent participation and support for New England missions. Oxford-educated aristocrat Robert Boyle, the son of Richard Boyle, Earl of Cork, served as the first Governor of the New England Company when the Restoration government rechartered it in 1662 and was the recipient of many of Eliot and Thomas Mayhew's early letters highlighting the progress and setbacks of their respective work. ${ }^{34}$ Cooperation and a wide degree of latitude in carrying out the missionary project locally in New England were characteristics of the project from its formal origins in 1649 and throughout the lifespan of the New England missions. ${ }^{35}$

Aided by the surety that indigenous conversions were proceeding according to God's plan and the eschatological roadmap gifted to humanity in Revelation, puritans in Old and New England approached Algonquian-speaking Indians with significant assumptions regarding the nature of Praying Towns and Indian Christians. Their "converts" proved quite capable of

\footnotetext{
${ }^{33}$ Broadside, "To our Reverend and deare Brethren the Ministers of England and Wales," (Cambridge, 24 October 1649), Bdses-Sm 1649 Oct. 24, MHS.

${ }^{34}$ John W. Ford, ed. Some Correspondence Between the Governors and Treasures of the New England Company in London and the Commissioners of the United Colonies in America, the Missionaries of the Company and Others Between the Years 1657 and 1712 to Which Are Added the Journals of the Rev. Experience Mayhew in 1713 and 1714, (New York: Burt Franklin, 1970), xi. The earliest records of the colonial branch of the CPG are unfortunately no longer preserved. The original members of the English branch of the CPG named in the parliamentary pamphlet were: William Steel, Harbert Pelham, James Sherley, Abraham Babington, Robert Houghton, Richard Hutchinson, George Dun, Robert Tomson, William Mullins, John Hodgson, Edward Parks, Edward Clud, Richard Lloyd, Thomas Ares, John Stone, and Edward Winslow. Pamphlet, "An Act for the Promoting..." DA27-L, MHS, 409. ${ }^{35}$ Correspondence and frequent communication remained essential to missionary activity, which subsequent chapters will explore in even greater detail. For now, it is worth mentioning that a description of New England towns presumably authored by Eliot highlighted that the author, John Cotton, and John Wilson (Boston minister) "doe weekely communicate counsells," which would have certainly included missionary information once Eliot fully committed to this activity. John Eliot, "Brief description of the towns of New England, 1650-1902," Ms. S565, MHS, 8. Francis Bremer's Congregational Communion remains the most exhaustive examination of clerical connections, which similarly inform the nature and form of New England missionary activity. Francis J. Bremer, Clerical Communion: Clerical Friendship in the Anglo-American Puritan Community, 1610-1692 (Boston: Northeastern University Press, 1994), 9.To further support the notion of latitude in how the colonial branch of the CPG carried out orders, a 1669 letter from the colonial leaders to Boyle stated that even though the English branch had halted spending on Algonquian-language works the colonial commissioners had authorized the printing of a small primer and catechism because both Eliot and Bourne had stressed the necessity of these texts for conversion and teaching. "Commissioners of the United Colonies to the Hon. Robert Boyle, Governor of the Company," Boston, 8 September 1669, in Ford, Some Correspondence, 30-33.
} 
challenging these beliefs throughout the life of indigenous missions. ${ }^{36}$ As Jean O' Brien has noted in Dispossession By Degrees, Eliot and colonial leaders imagined the existence of Indian converts in fixed, orderly towns, a stark social contrast to the free mobility which indigenous communities enjoyed prior to the advancement of English colonization. These "geographically bounded places" would function as the site where ministers and missionaries could didactically impress English religious and cultural imperatives upon their willing and passive subjects. ${ }^{37}$ The Clear Sun-Shining was followed by The Glorious Progress of the Gospel amongst the Indians of New England in 1649, in which Eliot commented on the difficulty of conversion "not only in respect of the language, but also in respect of their barbarous course of life and poverty." Eliot recognized that these planned towns would have to adopt English practices such as fencing and bounding the land because "their Corne is so spoyled by the English Cattell, and the English so loath to restore when they want fence, that it's a very great discouragement to them and me."38 Despite English cultural insensitivity, sustained missionary activity forced Eliot and others to afford native converts a certain degree of respect and autonomy as fellow brothers and sisters in communion under Christ, which afforded significant space for charting a path for indigenous religion, a subject considered in greater detail within the next chapter. Acquiescing to the realities of language and cultural barriers, what developed in practice were material and religious spaces initially dominated by indigenous "converts" empowered by a great degree of autonomy.

\footnotetext{
${ }^{36}$ In her consideration of "spaces of religious utterance," Kathryn N. Gray has highlighted the presence of Algonquian-speakers at the famed Cambridge Synod and their insightful questioning of Eliot after he delivered a sermon in Algonquian as a sign of the reality of "a certain respect and accommodation" which existed and allowed natives to negotiate an understanding and practice of Christianity from the outset of the missionary projects. Kathryn N. Gray, “'How may wee come to serve God?': Spaces of Religious Utterance in John Eliot's Indian Tracts," Seventeenth Century 24 (2009) 78-79.

${ }^{37}$ Jean M. O'Brien, Dispossession By Degrees: Indian Land and Identity in Natick, Massachusetts, 1650-1790 (Cambridge: Cambridge University Press, 19970, 26-27.

${ }^{38}$ Clark, ed. The Eliot Tracts, 152, 154.
} 
Eliot, Mayhew, and Richard Bourne were among the first New England missionaries to find themselves at the nexus of colonial power, a position which at times pitted them against colonial magistrates in favor of native rights and desires and provoked anxiety regarding their roles as cultural intermediaries. Likewise, their indigenous missionary counterparts often struggled with the same issues regarding place within the larger colonial world. From a governmental standpoint, New England's magistrates vacillated between legislation that benefitted Native Americans who fell within the shadow of colonial hegemony and passing laws which demonstrate European fears and exclusionary tendencies. Thus, laws pertaining to indigenous place within the colonies echoed some of their corresponding religious concerns. In Subjects unto the Same King, Jenny Hale Pulsipher argues that English colonials and Native Americans fundamentally disagreed on the place of natives within colonial government, as colonial magistrates tended to see them as lesser subjects and natives saw themselves as equals under the king. ${ }^{39}$ For example, the Massachusetts General Court passed a law on September 28, 1630 banning the use of firearms by "any Indian" and levying a fine or threat of imprisonment on the offending Englishman. This law was relaxed in 1634, which allowed selective colonists to train natives in their use for fowling, but was rescinded in 1637 with the growing conflict against the Pequot. ${ }^{40}$ Laws also attempted to govern material concerns, such as the regulation of trade, and worked to prevent Indians from acquiring certain possessions, such as horses, hogs, boats, and alcohol. A 1644 law ordered "that noe Indian shall come att any towne or howse of the

\footnotetext{
${ }^{39}$ Jenny Hale Pulsipher, Subjects unto the Same King: Indians, English, and the Contest for Authority in Colonial New England (Philadelphia: University of Pennsylvania Press, 2005), 18-20, 24. To Pulsipher, native resistance is best demonstrated in various moments where "subject" natives appealed directly to the English king to bypass colonial authority and assert their equality. (28)

${ }^{40}$ Alden T. Vaughan, ed., Early American Indian Documents: Treaties and Laws, 1607-178; Vol. 17: New England and Middle Atlantic Laws (Bethesda: University Publications of America, 2004), 77, 81-82.
} 
English (without leave) uppon the Lords day, except to attend the publike meeteings," continuing with a special provision for natives deemed subjects unto the English king:

... that these natives (amongst whome wee live, and whoe have submitted themselves to this govermente) should come to the good knowledge of God, and bee brought on to subject to the scepter of the Lord Jesus, it is therefore ordred, that all such of the Indians as have subjected themselves to our govermente bee henceforward enjoyned (and that they fayle not) to meete att such severall places of appoyntmente as shalbee most convenient on the Lords day, where they may attend such instruction as shalbee given them by those whose harts God shall stirr upp to that worke.

The law continues to encourage towns adjacent to these Indians communities to select from their midst "some of theire brethren (whome God hath best quallified for that worke) to goe to them, (beeinge so mett,) and instruct them." Immediately following this law was another ordering that "the Indians residing in the severall sheires shalbee civilized, and they shall have power to take order from time to time to have them instructed in the knowledge and worship of God." Subsequent laws formally banned native powwows, established fines for blasphemy against God by natives, and attempted to regulate various aspects of indigenous behavior such as marriage, hairstyles, and sexual conduct. ${ }^{41}$ While these laws appear draconian in the demands which they fostered upon natives, separated as they were in culture and language, Eliot attempted to ensure a degree of native autonomy through the establishment of Indian courts to regulate local native affairs and his advocacy in favor of native land rights; the General Court reciprocated by passing laws which attempted to regulate the sale of lands and to prevent the chicanery of unscrupulous colonists. Colonial law thus serves as another flexible aspect of English culture which reflected the tenuous place which Native Americans occupied in the minds of Englishmen, at times including and excluding them with schizophrenic reliability. ${ }^{42}$ Regardless, a brief examination of

\footnotetext{
${ }^{41}$ Ibid., 89-91, 96-99.

42 Ibid., 99-100, 105-106. Daniel R. Mandell, Behind the Frontier: Indians in Eighteenth-Century Eastern Massachusetts (Lincoln: University of Nebraska Press, 1996), 14-15. In addition to the frequent shifts in laws
} 
colonial law adds a political depth to the notion of English contrarianism in determining the exact place which Native Americans could occupy within the colony.

By the time Mayhew and Eliot began work in earnest to deliver sermons in Algonquian dialects and establish Praying Towns for the religious and cultural conversion of Massachusett and Wampanoag Indians, the dislocations of plague, warfare, and encroachment had significantly undermined native lifeways on the continent. Mayhew began his efforts as early as 1643, after his father obtained title to the island of Martha's Vineyard and Elizabeth Island, and Eliot most clearly took interest in missionary activities around 1646 in the wake of conflict with both the Pequot and the Narragansett. ${ }^{43}$ Scrambling for purchase in a world that was quickly dissolving underfoot, native groups grasped for means of survival in light of these power shifts. By centering this study on native perspectives, it becomes clear that mere survival was not the only goal. Moving beyond survival, natives evaluated English culture and integrated the elements that they deemed necessary for success and regeneration in the rapidly changing New England world. Native spiritualism also informed these decisions and responses to missionaries and Christianity, as religious beliefs and practices remained integral to kinship and community. Thus, the question of the attractiveness of puritanism to Native Americans is a constructive means of inquiry into the nature of native "conversion" or affiliation with early New England missionaries and considers both the positive aspects of shifting identity and the real consequences that came with such changes.

governing native possession of firearms, colonial leaders took contrary stances on the role which Native Americans could play in the colonial militia, allowing them to train with their colonial counterparts in 1652 and reversing this decision in 1656. Vaughan, Early American Indian Documents, Vol. 17, 105, 108.

${ }^{43}$ Clark, ed., Eliot Tracts, 9-10. Many of Mayhew land deeds from the 1640s through the 1680s are found in the Massachusetts Historical Society Naushon Papers. Ms. N-2308 Naushon Papers, 1641-1947, Box 1, MHS. 


\section{Family and Kinship in Native Decision-Making}

Protestant Christianity, particularly the strain of puritanism found in New England, emphasized conversion as an inward-facing, individualized experience. This conversion also bore markers of outward change that converts could point to in public confessions. When considering the "conversion" of Native Americans it is worthwhile to reflect on how this notion of conversion translated into collective societies that often subverted individual will and action to the leadership and guidance of the community at large, as well as the material concerns shaping native decision-making. ${ }^{44}$ Historians of native missions have also stressed the contested nature of "conversion," rejecting earlier religious accounts that conceptualized this transformation as whole or complete in favor of syncretic practices that recognize native agency in accepting or rejecting theological tenants and applying them in culturally specific ways ${ }^{45}$ Here and throughout this essay I refer to "conversion" from a native perspective as the decision by an individual or group to enter into a close relationship with English missionaries that superseded preexisting communal ties, divorcing it of its specifically religious context. This association also entailed acquiescence to certain cultural or religious points, at least on the surface, to appease missionaries and remain in their community. Conversion also entailed a commitment to learn

\footnotetext{
${ }^{44}$ Butler, New World Faiths, 53-55. David D. Hall stresses that confessionalism was marked by both an emphasis on one's depravity and hope in the saving grace of Jesus. Hall, Worlds of Wonder, 123-25.

${ }^{45}$ Neil Salisbury stresses the intense cultural pressure put on natives to convert, arguing that dependency was the primary reason why some responded to Eliot and Mayhew while others resisted. When considering religious aspects of Praying Town communities, Salisbury also stresses analogous cultural elements like deathways as evidence for syncretism Salisbury, "Red Puritans," 33-35, 44. Similarly, Francis Jennings has stressed the Puritan efforts to legally restrict Praying Town Indians and suppress their religion. Native options, according to Jennings, "lay between perfunctory observation of accepted ritual and unqualified profession of fiath. To go outside that range was to commit the blasphemy for which death was mandatory. Jennings, "Goals and Functions," 205-206. Kenneth M. Morrison has also portrayed the missions as culturally haphazard and without clear goals towards acceptance in the wider English community. Morrison, "Coyning Christians," 89-90. Later historians such as Robert James Naeher and J. Patrick Cesarini have been more cognizant of the theological benefits provided by Puritan theology, and the role that this played in inducing natives to form a dialogue with missionaries like Eliot and Mayhew. Naeher, "Dialogue in the Wilderness," 346; Cesarini, "John Eliot's 'A breif History," 116. Likewise, Douglas L. Winiarski stresses that native religious practices and an "Indianized" form of Christianity contributed to cultural stability within Praying Town communities. Winiarski, "Native American Popular Religion," 148-49.
} 
from the English powwows (as early converts likely saw the missionaries) the practices and rituals necessary for pleasing their god and harnessing his manit for protection in their upended world. It was certainly not a total and complete apotheosis that Europeanized the individual Algonquian-speaker. Similarly, the term "converts" refers to individual natives or groups that chose to enter into this particular rearrangement of society, politics, and religion.

When engaging English missionaries like Mayhew and Eliot, Massachusetts and Wampanoags quickly recognized that certain crucial differences existed between the two groups. Puritans recognized only one god, rather than many, and insisted that many native beliefs and practices regarding creation and healing powwows were misguided at best or a product of satanic influence at worst. ${ }^{46}$ Associating with these missionaries and adopting some of the more stringent religious requirements, such as the rejection of powwowing, put these men and women at odds with their communities. In response, their families and neighbors often exerted a strong pull to bring them back, or lashed out against them due to their close association with the English. For example, New England's First Fruits (1643) mentions a "Sagamore John" who expressed interest in the missionaries only to be "kept downe by feare of the scoffes of the Indians, [and] had not power to make good his purpose. ${ }^{" 47}$ In the same tract, a Niantic named Wequash moved to the Connecticut community and abandoned all of his wives, save his first one, and was presumably poisoned by a group of natives he later attempted to convert. ${ }^{48}$

In his 1649 report, Eliot gave a lengthy account of a dying native woman whom he considered a devout convert. As she was dying she called her children to her deathbed and warned that their "Grand-Father and Grand-mother, and Unckles, \&c. will send for you to come

\footnotetext{
${ }^{46}$ Clark, ed. The Eliot Tracts, 58.

${ }^{47}$ Ibid., 59.

${ }^{48}$ Ibid., 62. The source is unclear whether or not these were Wequash's own people or another tribe, though the missionaries were quick to proclaim him a martyr for their cause.
} 
live amongst them, and promise you great matters, and tell you what pleasant living it is among them; But do not believe them" because they remained unconverted. ${ }^{49}$ An encounter between a Wampanoag convert named Hiacoomes and a sachem named Pake Ponesso turned particularly violent when Pake Ponesso "reproached [Hiacoomes] for his fellowship with the English, both in their civil and religious wayes, railed at him for his being obedient to them" and struck him squarely across the face when Hiacoomes replied that he was gladly obedient to them. ${ }^{50}$ The opening vignette about Towanquantick's attacker also falls within this vein of communal tension and violence to prevent the abandonment of these traditional societies. Hiacoomes' attack adds a new layer of complexity to Towanquantick's story: perhaps he knew his attacker but preferred not to divulge the identity of his attacker like Hiacoomes for fear of English reprisal. In a 1650 letter Eliot noted that a group of "profane Indians" near Wamouth were "smitten with the Pox" because powwows had encouraged a group of young men to draw Christianized natives back into their community. ${ }^{51}$

These examples demonstrate the disruptive nature of conversion and movement to English settlements or later Praying Towns around 1650. The pull of missionaries was particularly detrimental from the traditionalist native perspective when disease and its effect on communal health are considered, as plague deprived the community of valuable members to produce foodstuffs, serve as future leaders, and appease native gods. For families, it also drew converts to a fictive European-influenced lineage that threatened traditional kinship ties. Algonquians who chose to leave traditional communities and bind themselves more closely to the English often attempted to bring kin with them, reconstituting their lineage and kinship

\footnotetext{
${ }^{49}$ Ibid., 151.

${ }^{50}$ Ibid., 177.

${ }^{51}$ Ibid., 197. Eliot also noted that the native converts with them "say that the Lord hath wrought a wonder for them" in proving his displeasure with this group that sought to return them to traditional ways (197-98).
} 
relations in a new context, which further antagonized indigenous communities pressed for man and womanpower.

When the sachem Papassaconnoway decided to follow the English, he also admonished the sons of his that were present to join him in this decision, and "his eldest sonne ... gave his willing consent to what his father had promised, and so did the other who was but a youth." ${ }^{" 52}$ In a public confession of a Nipmuc christened "Anthony" by the missionaries, he stressed the rift that conversion opened between him and his brothers Wompooas and Totherswamp. Anthony resolved this when he recognized that he would still fight alongside his brothers in a war and would avenge them if they were killed, regardless of their spiritual pursuits, so perhaps he should "pray to God" as well. ${ }^{53}$ In another confession, Anthony stated that his "Parents taught [him] to pray unto many Gods," so when he heard that his brothers prayed he "disliked them" and decided to run away, returning only because he "loved [his] brothers." 54

When a Nipmuc named Monotunkquanit began to question whether he should convert after his son Samuel and a minister in Dorchester pressured him, his final persuasion came from the sachems Waban and Totherswamp. ${ }^{55}$ In a later confession, Monotunkquanit provides more insight into the conversion process when he stated that his "kindred said, praying is a vain thing, why will you pray?" and sent him out to inquire further. ${ }^{56}$ Perhaps the most sobering account of conversion comes from the confession of Piumbuhhou, who stated that he had heard from

\footnotetext{
${ }^{52}$ Ibid., 153. Salisbury stresses that many early New England conversions under the Jesuit Pierre Biard were politically motivated and carried out by sachems, while Puritan sachems often converted on their deathbeds to ensure that the English would care for their children. Salisbury Manitou and Providence, 72-76, 191. That said, these accounts traditionally represent group conversion as a pattern of native leadership and communal following. I would stress that the desire to maintain kinship ties and a lineage, or to build a new one out of a Christian identity, was an even more important factor in these decisions where imminent death did not serve as the animus for conversion.

${ }^{53}$ Ibid., 365.

${ }^{54}$ Ibid., 382.

${ }^{55}$ Ibid., 372.

${ }^{56}$ Ibid., 391.
} 
Waban and rejected praying to the English god: "I hated it, for I had a wife, and many children, and therefore I cared not for praying. I thought if they were any of them sick, the Pauwaus could make them well ... Then my wife and children died. then my afflicted poore heart came in." 57 Sometimes the loss of an entire family provided the impetus for conversion to those left with nothing in the wake of disease epidemics. Joining this new Christian lineage within Praying Towns such as Natick could provide kinship and support in mourning, material support in the form of land, housing, and provisions, as well as protective affinity with the Christian god.

The dialogic nature of Eliot's conversion process provides a particularly useful window into native questions on religious practice and ritual in a Christian context. During his visits with native communities, Eliot frequently devoted long periods of time to answering the questions that native groups posed, listing them (or those most notable or memorable to Eliot himself) in his reports to England. Close examination of these questions provides insight into the religiosity of individual and group conversion in New England and provides a glimpse into native conceptions of Christianity and the factors that induced conversion as a means of rebuilding community. Wequash, poisoned during his proselytizing native villages, provided insight into his decision to follow the English god when he told the missionaries he was "convinced and perswaded that [their] God was a most dreadfull God." ${ }^{58}$ Indeed, avoiding the punishment of this powerful and vengeful manitou through appeasement shaped many native questions and confessions, which also demonstrate a communal mindset. Though individuals may have made the initial decision to follow Christianity's god, concern for family members and their protection

\footnotetext{
${ }^{57}$ Ibid., 392.

${ }^{58}$ Ibid., 61. They also record that he was terrified by the ability of a lone Englishman to slay numerous Indian warriors, which is most likely a reflection on the slaughter of the Pequot. That the English god would tolerate or condone such a massacre terrified Wequash and convinced him that this was a powerful manitou worth following for self-preservation.
} 
provided the impetus for reaching out and persuading them to join a new lineage in nascent Praying Towns.

The questions Algonquian-speakers asked continued to focus on the family nature of religious practice and dictates of the English god. In one instance Eliot's audience asked if God would punish a child for the sins of a wayward father, "because in the second Commandment it's said, that hee visits the sinnes of fathers upon the children." ${ }^{59}$ The reference to the Old Testament commandments should promote some skepticism, since Eliot and Mayhew admit to polishing indigenous statements and confessions at other times in the tracts. ${ }^{60}$ Despite this cautionary statement, the relational aspect of sin and native preoccupation with sin makes the question of interpersonal relations plausible as natives navigated this aspect of Christianity. Dreams also played an integral role in Algonquian ritual and cosmology, as the Massachusett asked Eliot in 1646 "whether they should beleeve Dreames?"61 Natives interested in following the English god engaged missionaries like Eliot and Mayhew with the hopes of protecting or drawing on these traditional modes of religious observance and ritual in a new context: to learn the appropriate practices in service of England's god. On another occasion Eliot records an account of an indigenous dream that a black man who carried an "English mans book" told them that God was angry with them "and that he would kill them for their sinnes." 62 This supposedly occurred two years before contact with the English in the region and is a good example of Algonquian

\footnotetext{
${ }^{59}$ Ibid., 86. Desiring to effect conversion in the youth as part of a larger missionary strategy, Eliot responded to this question that the child would not be punished if he repented for his sins and those of his father. If he did not repent, then he would face God's wrath for the sins of both.

${ }^{60}$ Ibid., 339. This particular instance in the text of the Eliot Tracts will be discussed in greater detail later in the essay.

${ }^{61}$ Ibid., 95. In another set of questions reflecting the staying power of dreams and their interpretation, natives asked "Seeing we see not God with our eyes, if a man dream that he seeth God, doth his soule then see him?" (155) Another round of questioning produced the following question: "In wicked dreames doth the soule sin?" (161) ${ }^{62}$ Ibid., 119.
} 
conceptions of punishment at the hands of the Christian god in light of plague outbreaks and communal disruption.

The questions that emerged during these dialogues also show a profound concern for how communities are to function within a Christianized context, and how English beliefs shape community in general. Family and community were the traditional bedrock of native society and lineage, as The Glorious Progress of the Gospel (1649) mentioned that "they are carefull to preserve the memory of their Families, mentioning Unckles, Grand-Fathers, and Grand-mothers, $\& c$. and much studying the advancing of their houses and kindred," prompting comparisons to Jewish historical genealogy. ${ }^{63}$ This concern for family and kinship relations spilled over into the societies forming within Praying Towns like Natick and Punkapoag. Natives asked Eliot during a 1648 visit "if two families dwell in one house, and one prayeth, and the other not, what shall they that pray do to them that do not?" as a way of mediating communal relationships in light of Christianity. ${ }^{64}$ Probing the nature of Christian community even further, Eliot was asked why they should love a native stranger who is a convert more than a brother who is not. ${ }^{65}$ Questions such as these uncover the heart of reciprocity and kinship in native communities, as they essentially questioned whether primacy was vested in blood kinship or a fictive religious counterpart. Questioning the nature of sachem authority and religious conversion, Eliot's 1649 list contains these inquiries: "If a man be wise, and his Sachem weak must he yet obey him?" and "We are commanded to honour the Sachem, but is the Sachem commanded to lovve us?"66 Members of the audience were clearly concerned with the influence of Christian doctrine on leadership within

\footnotetext{
${ }^{63}$ Ibid., 164.

${ }^{64}$ Ibid., 155. In this same question set natives also ask what a husband should do if his wife leaves him because he prays, and if a young Christian native can marry a native man who is not converted (156).

65 Ibid., 190.

${ }^{66}$ Ibid., 196. This list also contains interesting questions regarding maximum age for conversion, the state of the child if the parent converts, and how people see and know each other in heaven and hell.
} 
a Christianized community and how a proper leader or sachem should act. Here the emphasis on reciprocity is particularly clear, as Algonquians expected a ruler to return their honor with similar affinity. It is also obvious that they scrutinized the English among them to determine how the English themselves practiced their faith and how they treated one another, so it is possible that these were barbed questions critiquing the behavior of the English themselves. Eliot himself recognized the negative influence the English often had on them, recommending that "a place must be found ... some what remote from the English" where natives could be instructed in Christian tenants, which eventually became the Praying Towns like Natick. ${ }^{67}$

Individual and group-minded conversion remained tied to kinship and family connections, which informed and shaped the decision to forsake traditional community and religiosity in favor of a closer connection with the colonists and missionaries in New England. Rejecting tradition often provoked the enmity of that very same community and could bring physical harm or death, as Hiacoomes, Wequash, and Towanquantick discovered through firsthand experience. Diminishing bodily power in communities wracked with disease, land appropriation, and factionalism was a grave concern for natives who intended to keep the English at arm's length. The desire of converts to draw entire family and kinship groups with them further exacerbated this trend and added to communal strife. The questions from Eliot's dialogues demonstrate both the seriousness of indigenous engagement with puritanism, for they truly sought to understand the nature of the soul, how Christianity shaped communal relations, and the aspects of native culture that could continue under the Christian god. In his examination of the Natick Indians' confessions, Daniel K. Richter notes the preponderance of "Second Table sins," or sins against the community rather than God, that the residents chose to emphasize in

\footnotetext{
${ }^{67}$ Ibid., 152
} 
their public confessions. ${ }^{68}$ The penchant in emphasizing wrath and punishment of their people also served as an explanatory mechanism for the transitions occurring in New England during the mid-seventeenth century, highlighting once again the notion that the Natick Indians had failed in the past to honor communal values. If family shaped native engagement or detachment from Christianity as missionaries presented it, kinship also directly influenced native visions for what the new communities at Natick, Punkapoag, and other Praying Towns would become.

If the consequences of severed kinship ties, hostility, and occasional violence represented the bitter reality that natives interested in Eliot's missions and residency in Praying Towns faced, it is worthwhile to briefly consider the spiritual benefits that they possibly saw in puritanism. David J. Silverman contends that the idea of "the curse of God" as an explanatory mechanism for centuries of loss developed in the eighteenth century within the context of the Stockbridge and Brothertown communities, as natives continually coped with dislocations and hardships. ${ }^{69}$ However, Silverman's observation is not a unique development in the eighteenth century, as losses were even more spectacularly widespread and tragic during the previous century. The origins of an indigenous understanding of God's punishing wrath as a central aspect of puritan theology are evident in the earliest moments where Indian Christians voice their own thoughts in the Eliot Tracts and especially in John Eliot's 1671 Indian Dialogues, a form of primer which he hoped English-speaking Indians and missionaries could read to hone their argumentation in favor of Christianity. At the same time, native missionaries and converts also expressed hope that honoring and obeying the English god would lead to a positive future.

In the preface to his Indian Dialogues, Eliot notes that they are "partly historical, of some things that were done and said, and partly instructive, to show what might or should have been

\footnotetext{
${ }^{68}$ Daniel K. Richter, Facing East from Indian Country: A Native History of Early America (Cambridge: Harvard University Press, 2001), 118-26.

${ }^{69}$ Silverman, "The Curse of God," 495-97.
} 
said," which naturally incurs caution in detailing history from Eliot's own wishful thinking. ${ }^{70}$ In one dialogue Piumbukhou discusses his conversion with a group of kinsmen who challenged him on the benefits he hoped to gain from Christianity, asking "if praying to God did bring with it outward plenty and worldly prosperity," to which he replied that the benefit of prayer was that "it teaches us to know God, and the evil of sin; it teacheth us to repent of sin, and seek for pardon." ${ }^{71}$ This message of repentance is echoed in Piumbukhou's sermon recorded by Eliot in $A$ further Accompt of the Progresse of the Gospel, suggesting that this was a concept which impacted Piumbukhou: "this is a day of mourning, and not so much for afflictions, as for our sins, now if we doe truly and heartily mourn for our sins, then the blessing is promised to us and God will find a time and way to comfort us." ${ }^{, 72}$ Changing behavior and seriously following God apparently served as a source of hope for a better future in Piumbukhou's mind, and he attempted in the dialogue to defend this in light of the observation that the Praying Indians were "poor still" despite knowing the "true way of being rich," which suggests that traditionalists or skeptics challenged the efficacy of this new life as well. ${ }^{73}$ In another dialogue, Eliot records Waban consoling a penitential kinsman with these words: "but they that turn to God, and believe in Jesus Christ, shall be judged to go with Christ to heaven and be ever with him in eternal glory." ${ }^{74}$ The notion of an eschatological end to suffering and healing and the emotional connection between sin, penitence, and a personal relationship with the English god certainly served as powerful religious motivations for embracing aspects of Christianity. ${ }^{75}$ Coupled with

\footnotetext{
${ }^{70}$ The later fictional dialogue with Metacom which ends in his conversion to Christianity obviously serves as the most fanciful example. Other dialogues involve Waban, Piumbukhou, and John Speen, among others, which grounds them in a historical context. Henry W. Bowden and James P. Ronda, eds. John Eliot's Indian Dialogues: A Study in Cultural Interaction (Westport: Greenwood Press, 1980), 61.

${ }^{71}$ Ibid., 65-66.

${ }^{72}$ Clark, ed., The Eliot Tracts, 338.

${ }^{73}$ Bowden and Ronda, eds., John Eliot's Indian Dialogues, 66.

${ }^{74}$ Ibid., 111-12.

${ }^{75}$ See also Naeher, "Dialogue in the Wilderness," 347-48, 352.
} 
the material benefits of the Praying Towns, these factors laid the groundwork for indigenous hope in a better future that would retain many aspects of traditional life and authority despite the goals of English missionaries.

\section{Future Visions and Communal Authority}

Native Americans in New England who chose to abandon traditionalist communities in favor of English-style Praying Towns did so with the knowledge that such a decision put them and their family members at odds with their families. They also understood that important cultural and religious differences existed between them and English missionaries like Eliot and Mayhew, and that these missionaries often scoffed at native lifeways. Nevertheless, they chose this path as a means of reconstituting or rebuilding communities in a new context, one that could hopefully protect them against further encroachment and militant traditionalists who continued to resist colonization and British settlement in New England. The ties of communal religion also served as the sinew that would bind these new polities together and give them adequate form. Furthermore, leaders in these new towns also sought to control the religious proceedings and application of Christianity within their own communities and did so within the framework of Massachusetts colonial law. By establishing their authority, Praying Town sachems reconstituted their political authority in a new religious context, appropriating much of the traditional power that powwows held in traditionalist communities. This power was also bolstered by the advantage that the language barrier gave to native community leaders, who seemed most likely to effectively proselytize their fellow community members.

Joshua David Bellin has suggested that studies of missionary communities during the colonial period "treat the mission as a performance space within which Euro- and Native 
American participants were implicated, indeed through what they created," and that a "real" identity is impossible to pinpoint in this context. ${ }^{76}$ With this admonition in mind, an exploration of the means that Wampanoag and Massachusett converts pursued to enter into a closer religious alliance with missionaries uncovers a number of instances where natives acted in ways they understood English missionaries to appreciate. ${ }^{77}$ This is immediately apparent in the creation of an initial set of laws by Waban and other community leaders (possibly with the help or suggestion of European companions) that reflect a strong English cultural proclivity. These laws instituted monetary fines for acts such as idleness, sex out of wedlock, wife-beating, and female nudity. They also insisted that men and women adopt European-style haircuts, live in individual dwellings if not married, and not eat lice. ${ }^{78}$ These laws clearly attempt to hew to English standards of respectability and culture for the purpose of continued interaction and favor. When engaging English missionaries and pursuing full religious membership in the community and leadership over other natives, converts also closely followed the scripted puritan dialogues emphasizing their own depravity and sin, and the recognition of their errors. ${ }^{79}$

The lens of colonial subjugation traditionally colors interpretations of the legal strictures of colonial government and Praying Towns, though laws did provide aspects of control and autonomy for native communities. Evidence of direct native participation in the May 26, 1647 order by the Massachusetts General Court is indeterminate, but the court's ruling is important in

\footnotetext{
${ }^{76}$ Bellin, "John Eliot's Playing Indian,” 2, 24.

${ }^{77}$ This notion of judging the "other" and attempting to satisfy one's conception of the other culture is most apparent in White's Middle Ground, where these mutual misunderstandings and accommodation strategies functioned for the sake of diplomacy and cooperation. Here, where native kinship groups strove to create a new community with missionaries like Eliot and Mayhew, the markers of some form of "middle ground" are apparent.

${ }^{78}$ Clark, ed., Eliot Tracts, 97-98. Though Europeans found the consumption of lice particularly repugnant, this was an important protection against infestations in dwellings as a method of pest control.

${ }^{79}$ The tract Tears of Repentance is largely composed of these confessionals. Again, Bellin suggests that these tracts be read more as a script for natives than as a sincere expression of the "real" Indian. Despite this challenge in mediation, it is possible to draw some context from the way the stories themselves are composed and the particular details, such as the pull of family members, those natives provide as motivating factors for their decisions to join them.
} 
the overall construction of sachem political authority and the survival strategies of Praying Town communities. The Boston court established civil jurisdiction over the Praying Towns with this order, which historians have traditionally interpreted as a step in the colonizing process. ${ }^{80}$ This interpretation stems from the establishment of magistrate courts that held the power to try natives in civil and criminal (though not capital) cases. It is important to add that the order continues in granting sachems "libertie to take order in the nature of Summons or Attachments, to bring any of their own people to the said Courts, and to keep a Court of themselves, every moneth if they see occasion, to determine small causes of a civil nature, and such smaller criminal causes." The order continues in granting sachems the power to appoint "Officers to serve Warrants, and to execute the Orders and Judgements of either of the said Courts," and mandates that fines imposed by either court be put towards "the building of some meeting houses, for education of their poorer children in learning, or other publick use." Finally, the mandate tasked Eliot with ensuring that "the Indians understand our most usefull Lawes." ${ }^{81}$ This order granted substantial power to Praying Town sachems (while still maintaining the overall sovereignty of the Boston court) and also attempted to fit natives within the schema of British law. Furthermore, it was predicated on the notion that a native understanding of the law, explained by Eliot, would equip sachems to govern within the English framework, providing them with a crucial survival strategy if such knowledge were obtained. ${ }^{82}$

\footnotetext{
${ }^{80}$ Neil Salisbury is most adamant in asserting that "Puritan missionaries first directed their efforts at detaching the Indians from their "savage" culture and initiating them to the ways of "civilization." He also states that "missionization officially began only after the Puritan colonies had carried out a war of extermination against the Pequots in 1637, and begun a war of attrition (waged diplomatically and economicall as well as militarily against the Narragansetts." Neil Salisbury, "Red Puritans: The 'Praying Indians' of Massachusetts Bay and John Eliot," The William and Mary Quarterly 31 (1974): 28, 30. Salisbury links the submission of Massachuset tribal sachems in 1644 to a chain of legal proscriptions that undermined their autonomy (30-31).

${ }^{81}$ Clark, ed., Eliot Tracts, 123.

${ }^{82}$ This also contrasts markedly with many of the notions articulated in Robert A. Williams, Jr.'s The American Indian in Western Legal Thought: The Discourses of Conquest. While legal justifications certainly bolstered English thoughts on the merits of colonization, and "conquest, colonization, and remediation of radically divergent peoples
} 
In envisioning the groundwork for survival and a rebuilt community, natives who chose to pray recognized the substantial political and social benefits that a close association with the English could provide them. Converts in Praying Towns also considered a special relationship with the English advantageous for diplomacy with other native groups in New England. Eliot informed readers in Strength out of Weakness (1652) that a "great Countrey" populated by other tribes existed between Connecticut and Massachusetts, and that already one tribe had sent envoys to Natick "desiring that some may be sent unto them to teach them to pray unto God." 83 If praying to God and residing in Praying Towns served as the visible markers for natives who sought closer communion with the English, then those who had already converted stood to benefit from a position as intermediaries between the English and these other tribes. Internal factionalism within tribal groups also confounded Eliot's attempts to draw together all converts into one central community at Natick, as the ascension of Josias to the sachemship at the death of Cutshamoquin alienated the Cohannet band from the Natick community and led them to form their own nearby town, Punkapoag. ${ }^{84}$

The converts who rose to positions of leadership in Praying Towns also took an active role in directing the faith and practices of their community, similar to the role that powwows played in a traditionalist society. ${ }^{85}$ The language barrier that necessarily existed between the

were mandated by a law that appealed to a Eurocentric conception of Human reason and by tactics of convenience that viewed a Christianized savage as a safe savage," this does not fully elucidate long-term British colonialism and the status of "conquered" people within semi-self-governing polities like Natick. Robert A. Williams, Jr., The

American Indian in Western Legal Thought: The Discourses of Conquest (Oxford: Oxford University Press, 1990), 199.

${ }^{83}$ Ibid., 226.

${ }^{84}$ Ibid., 304. Eliot writes this development off as part of a divine plan, as Natick would not have been able to adequately contain all of the natives that might choose to join them. This eventually led to the formation of a number of small Praying Towns throughout the region, which were ruled by principal natives and had their own dedicated teachers. Appendix three of Cogley's John Eliot's Mission neatly organizes this information for each village. Cogley, John Eliot's Mission, 256-58.

${ }^{85}$ Francis Jennings asserts that "Religion and government were so closely allied in Wampanoag society that when the Christian convert rejected powwows he simultaneously rejected the sachem's authority that derived from the ritual and doctrine in the powwows' custody." This is important in a study of the ways in which Wampanoags 
missionaries and natives ensured that a degree of autonomy in teaching and practice remained. It is clear that language provided a substantial barrier to English goals of a fully doctrinaire conversion, as Mayhew's successes with the Martha's Vineyard Wampanoag hinged on the cooperation of Hiacoomes, who facilitated his language learning, and Eliot admitted in The Light appearing more and more (1651) that he had "but little skill in their language" and needed assistance from translators. ${ }^{86}$ Thus, the language barrier continued to pose a fundamental challenge to conversion and instruction, yet it also provided space for native leaders to retain control or influence in the dissemination and application of Christianity. Earlier in 1647 a group of native converts asked Eliot whether or not they should attend the English meetings on the Sabbath or meet among themselves, since "if they come to the English meetings they understand nothing, or to no purpose, and if they met together among themselves, they had none that could teach them." In response, Eliot proposed that they meet together and let religious leaders pray for the gathering and then teach them to the best of their abilities, letting other leaders speak once they had finished. He also instructed the congregation to ask questions for the leaders to answer, and to remember the questions if they were not satisfied ${ }^{87}$ In short, the challenges of converting Praying Town residents and fully instructing them in Christian tenents ensured that the missionaries relied on their potential converts for crucial leadership roles. While Eliot himself may have possessed concerns regarding proper doctrine and its transmission, the reality of his inadequate understanding of Algonquian early in the missions forced him to improvise and leave religious instruction in the hands of native ministers.

reconstituted their communities in a "Praying Town" context, as it adds explanatory weight to the role that these sachems played as leaders in this new community. Jennings, "Goals and Functions," 201.

${ }^{86}$ Clark, ed., Eliot Tracts, 175, 187.

${ }^{87}$ Ibid., 125. 
By 1658 these leaders served an important role in teaching and leading their communities, despite their limited knowledge of Christian doctrine and English. In preparation for a day of fasting and prayer at Natick on September 15, 1658, leaders Waban, Nishokhou, Anthony, John Speene, Piumbubbon, and Wutasakompavin spoke to the gathered community to encourage and teach them. In a postscript Eliot noted that the exhortations were signs of the spiritual development of the converts, and that he only captured what he could of their preaching, presumably based on his own limited knowledge of Algonquian dialects. To compensate, he took what he understood and "cloathed it with our English Idiom which is the greatest difference which [he had] knowingly made." 88 Nevertheless, the gist of each brief discourse can be discerned and shortly noted: Waban spoke on sickness and the power of healing through Christianity; Nishokhou emphasized the importance of offering physical sacrifices to the English god; Anthony stressed fasting and prayer as actions that converts could take; Speene encouraged repentance to appease the god's anger; Piumbubbon explained that they might mourn at present but could rejoice in the promises of the afterlife; Wutasakompavin reiterated that following the English god would bring healing. ${ }^{89}$ What is clear from these examples is that these various speakers assumed positions of political and religious leadership through their close association with the English missionaries and through their role as religious intermediaries. These leaders achieved further recognition from English congregational leaders when they underwent the confession and covenanting process.

Waban and other community leaders sought to strengthen the bond between Praying Indians and English congregants through the pursuit of acceptable religious practices that met English expectations. By 1670 there is some evidence that they were largely successful in this

\footnotetext{
${ }^{88}$ Ibid., 339.

${ }^{89}$ Ibid., 333-39.
} 
venture, particularly in Mayhew's community at Martha's Vineyard. The 1670 Brief Narrative of the Progress of the Gospel begins with the mention of the creation of a new Mashpee religious community under the missionary leadership of Richard Bourne, and the ordination of a Mashpee named Jude as "Ruling-Elder" for the community and a Deacon in the Mashpee church. ${ }^{90}$ After Mayhew and Eliot conducted these affairs they traveled to Martha's Vineyard where they celebrated the Eucharist in the "Indian-Church" along with congregants from the "EnglishChurch" and conducted a brief service in both languages. ${ }^{91}$ Mayhew and Eliot also appointed two "Teaching-Elders" and two "Ruling-Elders" for the community and laid plans to expand the churches in the region. In this tract, Eliot also recognized that it was necessary to defend the appointment of natives to officer roles in the church: "I find it hopeless to expect English Officers in our Indian Churches; the work is full of hardship, hard labour, and chargeable also." Further stressing the difficulties, he noted that "An English young man raw in that language [knowledge of Scripture], coming to teach among our Christian-Indians, would be much to their loss; there be of themselves such as be more able, especially being advantaged that he speaketh his own language, and knoweth their manners." Finally, he conceded that "seeing they must have Teachers amongst themselves; they must also be taught to be Teachers: for which cause I have begun to teach them the Art of Teaching." ${ }^{92}$ After twenty years laboring to create missions at Natick, Martha's Vineyard, and the various other Praying Towns in New England, Eliot and Mayhew recognized that a great degree of their vision lay beyond their control and in the hands

\footnotetext{
${ }^{90}$ Ibid., 400.

${ }^{91}$ Ibid., 401. See also, Andrews, Native Apostles, 33-34.

${ }^{92}$ Clark, ed., Eliot Tracts, 401-402.
} 
of native religious leaders, who could choose to enact their own plans for the community while working within the matrix of English expectations. ${ }^{93}$

While earlier historians have emphasized the loss of autonomy and agency inherent in the creation of Praying Towns under the jurisdiction of colonial governments, a closer examination reveals a surprising amount of native control over their religious and political affairs due in part to the challenges of translation. English missionaries, eager to tout their successes in opposition to Jesuit missionary programs that extended to North America and Asia, recognized that sachems would have to carry much of the proselytizing load despite their best efforts to learn the language and translate the Bible into Algonquian dialects. ${ }^{94}$ The control over religious affairs maintained by Praying Town sachems in this context closely mirrored traditional models of authority, ensuring that these rebuilt communities maintained a relatively traditional polity structure, despite the new Christian influence and cultural directives of Eliot and Mayhew. Natives who chose to join communities like Natick recognized the tremendous break this created with traditionalist polities, but wagered that this decision would provide better chances for survival and recovery in a new colonial environment.

\section{Expanding Town and Church for Praying Indian Communities}

After Eliot and Mayhew launched their initial forays to convert their Algonquianspeaking neighbors and Natick developed as a model community in 1651, the early missions

\footnotetext{
${ }^{93}$ This is not to diminish the significant translation efforts of Eliot, who authored a catechism by 1651, which was printed in a number of subsequent editions, a collection of Psalms (first printed for English readers to examine in 1658 or 1659), and versions of Genesis and Matthew initially. By 1658 Eliot had finished an entire translation of the Bible, which was printed from 1660-1663. Again, it must be emphasized that Eliot's frenetic efforts lent to odd translations, and we can only speculate as to how Wampanoag sachems in Praying Towns made use of these texts. Cogley, John Eliot's Mission, 119-121.

${ }^{94}$ In correspondence between Eliot and a missionary society colleague named John Baxter, Baxter drew this connection explicitly: "The Industry of the Jesuits and Fryars, and their Successes in Congo, Japan, China, \&c. shame us all, save you." Clark, ed., Eliot Tracts, 434.
} 
experienced tremendous growth in the following decades, which serves as a measure of the attractiveness natives found in the social and religious offerings of the missions. In his contemporary description of New England towns, Eliot mentions Natick among New England's towns "by the blessing of God now beginning": an interesting inclusion when many maps from the same period conspicuously make no mention of Natick or other Praying Towns. ${ }^{95}$ In a 1669 letter to Robert Boyle, Eliot reported on the "resent state of the Indians in the Massachusetts government, in the matter of Religion," noting that Natick had progressed as the centerpiece of his project with thirty to forty full members in the church. John (Speen) and Antony served as ecclesiastical leaders while Waban, Piumbuhhow, Wutasakompauin, and Mishosinan served as civil rulers. Eliot continued to list the towns of Pakeunit, Ogquonikongquamesit, Hassannamesut, Maqwongkomuk, Nayhop, and Wamesut along with the general leadership of these communities to demonstrate the progression of both ecclesiastical and civil development. ${ }^{96}$ A 1670 letter by Eliot to Henry Ashurst, treasurer of the Company, mentioned that Natick's population had begun to reach out to other communities inviting others to join them and pray to God, while a 1671 letter by Thomas Mayhew to the colony's commissioners noted that the Martha's Vineyard communities had organized two churches in the immediate vicinity and three others on the main island and Elizabeth Island. ${ }^{97}$ At the same time, Richard Bourne, a leader at Sandwich in New Plymouth, began making inroads with the Wampanoags to obtain grants of land at Mashpee and organize communities similar to those of Eliot and Mayhew. ${ }^{98}$ Before the disastrous upheaval of King Philip's War, there were approximately fourteen Praying Towns with over 2,000 residents that held the potential to grow even larger as Eliot's indigenous missionaries began earnest

\footnotetext{
${ }^{95}$ Eliot, "Brief description of the towns," Ms. S-565, MHS, 5. Map 1 and Map 2 in Appendix B.

${ }^{96}$ Ford, ed., Some Correspondence Between the Governors and Treasurers, 27-30.

${ }^{97}$ Ibid., 37, 41.

${ }^{98}$ Mandell, Behind the Frontier, 18-19.
} 
efforts to bring the Nipmuc and Wampanoag into this growing network. Indigenous religious and political leaders governed their communities in a mixture of English and Indian practices, architecturally evidenced in the combination of wigwams and English-style buildings at Natick. Judging by the sheer expansion of communities, the formation of networks between them, the growth of literacy through the instruction and catechesis of children, and the development of civil and ecclesiastical leadership, the early history of the Praying Towns is clearly one of optimistic recovery and growth despite friction with nearby English settlements and traditionalist communities. Religious and material concerns often coincided, making this new model of life appealing to those who settled into the expanding web of Praying Towns.

Though the appeal of protection from the powerful manitou of the English served as a powerful impetus for natives to join communities at Natick, Punkapoag, or any of the other nascent communities throughout the English colony, this did not prevent disease and attacks from other hostile Indians from disparaging their progress. Eliot wrote in a 1669 letter to Boyle that "many of our choice instruments of this place are dead," echoing the 1652 news from the tract Strength out of Weaknesse, which noted the sobering effect of smallpox as it swept away a number of his early converts. ${ }^{99}$ Prior to Eliot's 1669 report, the English supervisors of the CPG learned that efforts to train two Indian students at Harvard as missionaries proved unsuccessful, as one was lost in a shipwreck while traveling to visit his family at Martha's Vineyard while the other had graduated but had taken sick and was to die soon. The same report also included an account of the money spent on powder and shot to supply the Indians at Natick and its environs to defend against Mohawk attacks because they had "slayne sundry of them." 100 At the town of Wamesut the community was divided between Praying Indians and those who rejected "praying

\footnotetext{
${ }^{99}$ Ford, ed., Some Correspondence Between the Governors and Treasurers, 28; Clark, ed., The Eliot Tracts, 221-24.

${ }^{100}$ Ford, ed., Some Correspondence Between the Governors and Treasurers, 13-14.
} 
to God \& refused to desist from pawwauing," each with their own garrison to protect from Mohawk raids which had previously taken the life of the brother of sachem Nomphow. Armed by the English, these two communities put aside their differences to launch an abortive raid against nearby Mohawks which took the life of most of the sachems and the majority of the traditionalist warriors, which "the Indians take notice off."101

The English population within the Massachusetts Bay and Plymouth colonies proved to be less enthusiastic and supportive of the growing missionary projects of their fellow ministers, and colonial leaders proved similarly skeptical of the viability of indigenous communities within English society as evidenced in the legal prescriptions regarding Native Americans from 1630 to 1660 discussed in various contexts above. As a result, missionaries and their supporters faced the difficulty of advocating for their potential converts amidst growing cultural tensions that would eventually erupt in full-scale war in 1675. Despite Eliot's excitement with the founding of Natick as the first organized Praying Town in 1651, and his millennial certitude that this model of sacred polity would continue to flourish as a fulfilment of biblical prophecy, the settlement of Massachuset and Nipmuc converts in close proximity to the English fringe settlement of Dedham quickly provoked the ire and frustration of Natick's English neighbors. Eliot's initial conviction that his converts at Natick would benefit from close proximity with the Dedham community proved to be sorely naïve and a constant source of friction for the Praying Indians within that town, as well as Okonokhamesitt, which was similarly founded near the English community of Marlborough, an offshoot of Sudbury. ${ }^{102}$ In a 1657 letter to Major Humphrey Atherton, an

\footnotetext{
101 Ibid., 29-30.

102 Pulsipher, Subjects unto the Same King, 74, 76-77. Alden T. Vaughan has also noted the conflict which developed between Okonokhamesitt and Marlborough. Alden T. Vaughan, New England Frontier: Puritans and Indians 1620-1675, $3^{\text {rd }}$ edition (Norman: University of Oklahoma Press, 1995), 290-91. The most thorough account of the conflict over land between Natick and Dedham remains Jean M. O'Brien's Dispossession By Degrees. O’Brien, Dispossession By Degrees, 32-42.
} 
influential military and political leader within the colony who resided in Dorchester, Eliot thanked him for allowing the Punkapoag settlement within Dorchester land, and for Atherton to record in the transfer of land to the Indians in the town records because "our poor Indians are much molested in most places." In addition to this request, Eliot also asked that Atherton “appoint fitting men, who may, in a fit season, bound and lay out" Punkapoag, strategically calling on Atherton as an influential benefactor and ally against the speculation and hostility of the communities which bordered Praying Towns. ${ }^{103}$

At the same time, Thomas Mayhew also found himself frustratingly caught between his Wampanoag friends and the colony at large, as he wrote in a 1671 report to the New England commissioners:

I have used my best skill \& hedpes to discover anything that might tend to the hurt of our nation in doing whereof sometimes with others I have beene sorry to sitt \& heare such onreasoneable Constructions that have beene made \& prest I have always Judged myselff uncharitable enough to the Indians \& to apt to take offence against them though it has been usually apprehended to the Contrary: I have taken course to prevent suspition as much as I can \& will doe god willing that wee may avoyed censures... ${ }^{104}$

In a similar letter to New Plymouth governor Thomas Prince, Mayhew wrote: “my error hath been, in all cases, that I am too favorable to English; and it hath always been very hard for me to preserve myself from being drawn to deal over-hardly with the Indians.” In stressing his English loyalty and admitting his occasional harshness to the Wampanoag on Martha's Vineyard, Mayhew reassured Prince that "there is no manner of plot known to any of the heads of this island" in the brewing tension surrounding Metacom and that the sachems had given Mayhew their word that they would support the English in any

\footnotetext{
${ }^{103}$ Letter, "John Eliot to Major Humphrey Atherton, 4 April 1657," in Collections of the Massachusetts Historical Society 1:2, 9 .

${ }^{104}$ Ford, ed. Some Correspondence Between the Governors and Treasurers, 42-43.
} 
future conflict. ${ }^{105}$ Despite the best efforts of Eliot and Mayhew, the violence that engulfed the colony in 1675 held disastrous immediate effects for mainland Praying Indians.

\section{Conclusion}

The religious and political life of New England native groups like the Wampanoag or Massachusett proved a dynamic and driving force in the social and political lives of these communities. Sachems augmented their power with the ritualistic function of the powwows, which explained the origins of their people, their relationship with the land and environment, and the causation behind natural phenomena, illness, and adversity with other tribes. Waban, Towanquantick, and many other Native Americans found traditional manit and the rituals of their powwows an insufficient solution to the diseases and dislocations initiated by European colonization. Disruptions of such magnitude required innovative solutions. Impressed with the apparent power of English manit, which prevented them from succumbing to the same plagues, they decided to align themselves more closely with the English to unlock the secrets of their god and his devotional rituals.

If New England's colonists frequently clashed with indigenous cultures in disastrous ways, evidenced in the Pequot War and the execution of Miantonomo, transatlantic news of civil war in England and the millennial eschatology latent within puritanism created a cultural bridge by which ministers such as John Eliot and Thomas Mayhew were able create conceptual space for Indians within a shared imagined community. Apocalyptic thought also created a sense of urgency to carry out these conversions in the face of Christ's imminent return. While the ideal of

\footnotetext{
105 Letter, "Thomas Mayhew to Governor Thomas Prince, 19 June 1671," in Collections of the Massachusetts Historical Society 1:6, 196-97.
} 
English missions contained imperialistic assumptions about fixity, order, and their own cultural superiority, the reality of cross-cultural religious exchange ensured that the Praying Town communities that developed in New England operated with a great deal of autonomy. Nevertheless, John Eliot and Thomas Mayhew imagined native converts as their spiritual brothers and sisters under Christ, and indigenous churches as a part of the larger religious fabric of their godly commonwealth.

The decision to abscond from traditional polities and draw close to the English created intense political and societal pressure on those who remained with traditional communities and those who left. The importance of kinship and familial ties ensured that those who stayed pressured converts to rejoin them, occasionally using violence to express their disgust or formal rejection of sachems like Towanquantick or Hiacoomes. Likewise, Indian Christians often turned to face their families and sought to bring them into communities like Natick as well. Losing his brothers Wompooas and Totherswamp to the English faction provided the impetus for Anthony to join them. For Piumbuhhou it was the loss of his entire family that induced him to join the English. When a lineage was completely disrupted, survivors had few choices or alternatives at hand. Kinship and family proved to be important in native questions pertaining to the Christian faith, as evidenced in Eliot's missionary dialogues. These concerns also factored into native questions of Christian governance and an understanding of what an Indian Christian polity would be. Faced with a choice between remaining within faltering communities or joining the expanding network of Praying Towns, historians must confront the appealing aspects of this shift from an indigenous perspective. While Praying Towns offered a more firm recognition of land rights, access to literacy and colonial courts, and the creation of powerful cultural ties with 
English missionaries, puritanism also offered a cosmological script for understanding past losses and visions for the future.

Traditional accounts of colonization in New England fit the missionary project of the 1650s and beyond into the wider framework of colonial subjugation. These missions provided an important framework for producing docile Indians who conformed to English cultural norms, or so the reasoning goes. Hagiographers have touted the spiritual merits of Eliot and Mayhew's missionary project, while ethnohistorians have stressed that natives vehemently resisted this assault of cultural whitewashing. Recognition of the native decision-making process and the role of sachems in establishing new polities in Praying Towns call many of these assumptions into question. Conversion and aligning with the English in Praying Towns provided the ground on which new native communities could be built. The language barrier between English and Algonquian dialects ensured that sachems or former powwows retained control over the religious life for their people, emphasizing the aspects of Christian doctrine that they liked in ways that appealed to their new lineages. Sachems also retained an important degree of political autonomy in governing their people and gaining a better understanding of English law and custom. These points all contribute to the notion that missionary communities provided natives with both the means of survival and the opportunity to establish new communities that made the best of a world fundamentally changed by colonialism. That converts actively chose this life and drew on kinship ties to strengthen the physical body of this community is worth reiterating to stress the great degree of continuity in this new polity, despite the goal of Europeanization initially held by Eliot and other puritans. Religious ritual and practice in service of the Englishman's god also served as a form of cosmological comfort in explaining the reasoning behind past destruction. The decision to follow the English god was thus born out of a search for a new source of spiritual 
strength, which could lay the groundwork for rebuilding and a healthy community. In this sense, Praying Indians looked to the future and sought to integrate aspects of Christianity, including its eschatological outlook, as they faced future challenges.

The following chapter explores the nature of indigenous converts and the presence of native churches within the congregational and clerical framework of New England's society. Of particular importance are the ministerial connections between Praying Towns and with the wider ecclesiastical body of the colony. In the wake of the Restoration, New England puritans also debated the exact nature and scope of conversion with the passage of the Half-Way Covenant of 1662. The validation of theological preparationism within mainstream religious thought in the colony held important significance for puritan understandings of native conversion and regeneration. 


\section{Chapter Three \\ The Long Road to Sainthood: Praying Indians and the Half-Way Covenant of 1662}

And look, as some may be externally Dogs, and yet internally Believers: (as the woman of Canaan, whom, in respect of outward Covenant, Christ calls a Dog: and the Jews, who yet rejected him... so many may be externally Children, in respect to external Covenant, and yet internally Dogs, and evil men...

Thomas Shepard (1663)

As Thomas Shepard intimated in the quotation above, a passage from a pamphlet published after his death in 1649 in support of the Half-Way Covenant of 1662 titled The Church Membership of Children, and Their Right to Baptisme (1663), puritans perpetually struggled with distinguishing the elect from the damned. ${ }^{1}$ While conversion accounts offered potential guideposts to determining a person's eternal state, when New England puritans ventured out of their homes and rubbed elbows with neighbors throughout the week and at the regular congregational gathering on Sundays the inward struggle to discern one's cosmological place became even more complicated. Reflecting on their own successes and failures, they also judged the outward actions of their neighbors as evidence of an inward transformation and election. When piercing the veil of the flesh in an attempt to determine the nature of a soul, Shepard contended that outward appearances could be deceiving: "dogs" might really be saints, and the most pious members of the community might instead be damned in actuality. How much more difficult was it to read the outward appearance and inward state of Praying Indians, whose cultural heritage remained foreign and at times offensive to puritan colonials? Could these Indian Christians, popularized by John Eliot and Thomas Mayhew, be among the elect?

It was during the spring thaw of May 1659 that Nishohkou cleared his throat and stepped forward before the gathered congregation at Roxbury, glancing at John Eliot, who stood by and

\footnotetext{
${ }^{1}$ Thomas Shepard, The Church Membership of Children and their Right to Baptisme (Cambridge: Samuel Green, 1663), 2.
} 
prepared to translate his words to the gathered crowd. He had spoken about his life and spiritual developments under Eliot's tutelage already that previous February to a gathered crowd of Roxbury elders and church members, and prior at an examination held in Natick in 1653, but it failed to make recounting his losses and his life experiences any easier. As he prepared to give yet another account of his sincerity and all that he had learned from the English about his sinfulness and desire to repent and own the covenant as a full member, he certainly had reason to wonder if this time would be any different, and if the English would ever accept him and his fellow townsmen at Natick as equals. He also had reason to think back on the various points of catechesis and how he might highlight these in his story: man's original fall from a state of perfection, his sin prior to hearing the gospel, his wayward heart and his internal struggle to realize God's grace and his desire to return to traditional ways. He summoned his courage and began to speak, pausing from time to time so that Eliot could transform his words from Algonquian to English. After all of his brethren delivered their confessions, delayed by the time it took to translate their confessions and the questions they received when they each finished, Eliot and the gathered ministers conferred together. When they were finished, Eliot told Nishohkou and the others that the ministers had found their confessions and inner turmoil to be evidence of true grace, and that they could now build a visible church at Natick. In 1659, the mood for the Praying Indians was understandably optimistic, as this examination had brought to fruition years of patience and effort to learn from the English and their expectations. With all of the necessary gravity, they could formalize their church covenant and gather as a body of visible saints within the network of town churches that spanned puritan New England. Perhaps the English would accept them now that they had reached another important marker on the long road to sainthood. ${ }^{2}$

\footnotetext{
${ }^{2}$ These reflections on the thoughts possibly coursing through Nishohkou's head are developed primarily from the
} 
The journey from gathered civil polity at Natick to a communion of Indian saints under formal church covenant was a long and difficult one that required Indians and their missionary allies to navigate the complicated theological expectations of the larger body of English ministers and magistrates. While previous studies of Praying Indian communities have adequately grounded indigenous experience in the social, political, and economic context of colonial expansion prior to King Philip's War in 1675, emphasis on the creation of a distinctly religious and Indian community in the midst of theological debates and developments within puritan New England is decidedly lacking. ${ }^{3}$ The complex cultural workings of puritan covenant theology and the morphology of conversion profoundly impacted not only ministers directly involved in missionary projects within the colony, but these cultural imperatives also shaped the understanding and acceptance of "Praying Indians" as a category and type of congregation for the rest of the colony's ministers. Central to this analysis is the development of an understanding of where Praying Indians stood in the minds of New England's ministers during the years of 1648 to 1675 , and how native missions shaped their thinking regarding the expansion of church

confessions recorded in the Eliot tract A further Account of the progress of the Gospel Amongst the Indians in New England (1660). Michael P. Clark ed., The Eliot Tracts: With Letters from John Eliot to Thomas Thorowgood and Richard Baxter (Westport: Praeger, 2003), 358-364, 376-381, 395. Nishohkou's earlier confessions were recorded in Tears of Repentance (1653), pp. 286-289.

${ }^{3}$ In Behind the Frontier, Daniel R. Mandell summarizes the extent of Puritan and Indian interactions from the seventeenth century in just one chapter, and places no real emphasis on the changes and debates going on within Puritan culture. While his focus is admittedly on crafting an Indian history, it is important to consider the extent to which Puritans were willing to welcome Indians into their religious body, and the barriers which prevented such inclusion. See Daniel R. Mandell, Behind the Frontier: Indians in Eighteenth-Century Eastern Massachusetts (Lincoln: University of Nebraska Press, 1996), 8-23. Jean O'Brien's work provides an excellent understanding of the various forces which beset Natick and Praying Indians in their loss of land, arguing that "colonists could imagine a place for Indians within the colonial social order only as social, cultural, and religious converts fixed in bounded places where English notions of property and 'propriety' would prevail." O'Brien similarly offers no analytical weight to the religious forces which shaped the experiences of Praying Indians. Jean O'Brien, “"They are so frequently shifting their place of residence': Land and the Construction of Social Place of Indians in Colonial Massachusetts," in Martin and Rick Halpern, eds., Empire and Others: British Encounters with Indigenous Peoples, 1600-1850 (Philadelphia: University of Pennsylvania Press, 1999), 208. For more on the social function of the church on Martha's Vineyard instead of the mainland, see David J. Silverman, "The Church in New England Indian Community Life: A View From the Islands and Cape Cod," in Colin G. Calloway and Neal Salisbury, eds., Reinterpreting New England Indians and the Colonial Experience (Boston: The Colonial Society of Massachusetts, 2003), 264-298. 
membership within the colony as a whole. ${ }^{4}$ If linguistic barriers necessitated a great deal of autonomy and created a religious "middle ground" where Indians could develop a theology which integrated aspects of puritan Christianity, missionaries and the wider body of ministers served as the final judges of the outward behavior and expressions of Indian Christianity.

The key theological development which divided the colony prior to King Philip's War was the series of platforms advocated by a gathered synod in Boston, which culminated in the Half-Way Covenant of 1662. As New England ministers variously supported or rejected the expansion of church membership through baptism to a wider portion of the unregenerate, they launched a flurry of polemics to support their position and disparage opponents. Congregations vehemently resisted the covenant's application within their own churches, locking them in conflict with ministers who expressed their support for the measure. For decades to come, the gradual adoption of the Half-Way Covenant and its spread throughout the New England colonies shaped the theology of a new generation of New England ministers, including Solomon Stoddard, particularly on the merits of theological and spiritual preparation. The Covenant also intended to regenerate the shrinking body of the elect through the creation of new religious lineages severed by the second generation of colonial youths who did not have the profound conversion experiences their parents underwent in England. ${ }^{5}$

\footnotetext{
${ }^{4}$ Kathryn N. Gray states that "colonial ministers, missionaries, and magistrates continued to control many of the rules concerning religious speech, through the organization of prayer, as well as the forms and functions of sermons, examinations, and confessions," arguing that the spaces in which these exchanges took place were more contested, though her focus on literary theory and analysis would benefit from a closer examination of the theological workings of New England and its ministers, which is the focus of this chapter. Kathryn N. Gray, John Eliot and the Praying Indians of Massachusetts Bay: Communities and Connections in Puritan New England (Lewisburg: Bucknell University Press, 2013), 59.

${ }^{5}$ Adam Seligman argues that the Half-Way Covenant was the first step in an effort to address problems associated with the institutionalization of "grace" through the church covenant and the tension between an insular community and outsiders that hit closer to home when the second generation of children born in the colonies failed to have the same conversionary experiences. Adam Seligman, "Inner-Worldly Individualism and the Institutionalization of Puritanism in Late Seventeenth-Century New England" The British Journal of Sociology 41 (1990): 541-46. Philip F. Gura has closely examined resistance to the Covenant in Northampton, Connecticut under Eleazer Mather, which is where Stoddard assumed the pulpit and further pioneered the expansion of communion and membership to the
} 
Where do Indian Christians stand in a debate that largely took place in English, between puritan ministers who were well-read not only in the Bible, but also in the writings of England and New England's leading puritans? While there is no existing evidence that Praying Indians took part in the Synod of 1662's deliberations and the crafting of the Half-Way Covenant, the earliest experiences of Praying Indians at locations like Natick, Punkapoag, and Martha's Vineyard served as a powerful example in favor of theological preparation and the creation of new religious lineages out of an unregenerate Native American population. Catechesis and intensive religious indoctrination served as an efficacious example to emulate with colonial children. Analyzing the earliest reports of colonial missions through 1662 reveals that the difficulties of overcoming the linguistic barrier between English and Algonquian dialects forced English missionaries like Eliot, Mayhew, and Richard Bourne to embrace preparationalism and long-term sanctification as the best method to conversion and the only way to satisfy their desires to change Indian culture in the face of opposition from Native Americans themselves and

Puritan body at large. See Philip F. Gura, "Preparing the Way for Stoddard: Eleazer Mather's Serious Exhortation to Northampton," The New England Quarterly 57 (1984): 240-249. Both Ross W. Beales, Jr. and Gerald F. Moran have examined the implementation of the Covenant in locations such as Dorchester and Milford, Connecticut to demonstrate that the declension myth and idea that the second generation remained indifferent to church membership, even with the passage of the Covenant in 1662, are unfounded. In Dorchester, it was only after the first generation of Puritans lost control of church government that the younger community fully adopted the covenant and even extended it further. Similarly, Moran noted that membership within the church occurred after social markers of adulthood were reached, such as marriage or the birth of children, and that membership tended to persist throughout family lineages, as "socio-religious circumstances combined with the actions of the family to produce a tribal spirit and an inbred membership." Ross W. Beales, Jr. "The Half-Way Covenant and Religious Scrupulosity: The First Church of Dorchester, Massachusetts, as a Test Case," The William and Mary Quarterly 31 (1974): 468, 479. Gerald F. Moran, "Religious Renewal, Puritan Tribalism, and the Family in Seventeenth-Century Milford, Connecticut," The William and Mary Quarterly 36 (1979): 238, 247-52. E. Brook Holifield also argues against the traditional argument that irreligious middle class merchants led the way for the colony's decline, demonstrating that the split within Boston's Third Church with the appointment of John Davenport did not easily follow vocational lines. Similarly, later persecutions of Baptists and Quakers did not clearly follow religious lines, as those who supported the Half-Way Covenant seemed to be the most zealous in persecuting Baptists in comparison to “traditionalists." E. Brooks Holifield, "On Toleration in Massachusetts," Church History 38 (1969): 189-91, 195. Finally, the colony struggled throughout these decades with adherence to a purely Congregationalist model amidst Presbyterian sentiments, which made the statements on synods and their power in the 1662 Covenant threatening to those who sought to limit ministerial authority. Paul R. Lucas contends that the growth of Presbyterianism stemmed from a desire to shore up the power of the colony's ministers in the wake of divisive factionalism. Paul R. Lucas, "Presbyterianism Comes to Connecticut: The Toleration Act of 1669," Journal of Presbyterian History 50 (1972): 135-37. 
Englishmen who often doubted their visible sainthood. The appropriate starting point for this analysis begins with the organization of Indian Christian communities and a comparison between Eliot's desires for the Praying Town - to forge an autonomous Indian Congregationalist church with a covenantal body of the Indian elect - and Native American desires which sometimes diverged from Eliot. Beyond the Praying Towns, it is important to consider the participation of Praying Indians in the wider religious activities of the colony as a whole and the developments of a distinctly Indian form of congregationalism that sought to balance their cultural heritage with innovations taken from the English.

Similarly, the wider colonial developments of the English Restoration and the Half-Way Covenant bore a tremendous impact on the early history of New England's Praying Towns. If the Restoration brought closer scrutiny and a heavier hand from James II and his ministers, the coming of age of a new generation of puritans created a crisis of sorts for the older generation and required new perspectives on the inclusion of new members. The failure of the millennial predictions of Brightman and other mystics to materialize similarly dampened the spirits of many New Englanders. An analysis of puritan understandings of conversion on one hand, and spiritual preparation on the other, necessarily affected the standing of Praying Indians within the minds of English ministers. The use of a preparational mode of conversion within Indian missions also played a role in preparation's wider adoption throughout the colony at the same time. Thus, these developments fundamentally linked Indian missions and mainstream puritan thought. David L. Parker defines preparation as a "process by which the penitent, while still unregenerate, was gradually brought to realize his absolute need of and dependence upon God's free grace." The soul found aid on this pilgrimage when the convert "read the Scriptures, attended the preaching, and meditated upon particular scriptural and doctrinal truths as applied to his personal 
condition." This primed the convert over an extended period of time for the reception of grace and salvation. ${ }^{6}$ In delineating the nature of salvation and visible sainthood, a body of Massachusetts ministers gathered in 1640 and stated, among other things, that the unregenerate showed no special evidence or assurance of God's love. Thus, the testimony of a true believer served as the only means of demonstrating a valid spiritual transformation. ${ }^{7}$ These connections are most apparent in the debates surrounding Indian conversion and the attitude of puritan ministers in judging the sincerity of Indian converts. Concerns about the Half-Way Covenant and its implementation continued after 1662 and remained unresolved by 1675, but for the purpose of this chapter it is worthwhile to note that these debates also shaped the perspective of New England's ministers on Praying Indians.

As tensions rose in the years before King Philip's War broke out in 1675, Praying Indians faced a variety of religious and social challenges to their survival as communities. The Natick community not only entered into their first of many boundary disputes with neighboring Dedham

\footnotetext{
${ }^{6}$ David L. Parker, "Edward Taylor's Preparationism: A New Perspective on the Taylor-Stoddard Controversy," Early American Literature 11 (1976): 259-60. For more on how this contrasts with early Puritan understandings of conversion and grace, as well as the paradox which infant baptism created with the Calvinistic tradition's notion that adults must be cognizant of their own spiritual awakening, see C.J. Sommerville, "Conversion versus the Early Puritan Covenant of Grace," Journal of Presbyterian History 44 (1966): 179-197. According to Sommerville, the standard Puritan covenant served as a safeguard against "the dangers of such a subjective and individual doctrine of grace," as well as a means to placate fear and uncertainty regarding an individual's status among the elect (179-80). Michael P. Winship argues that Puritan conceptions of success for their North American endeavors were tempered with a situational understanding of prophecy and millennialism. While signs might have pointed to certain future events, the mystery of God and his actions ensured that events might not come to pass as Puritans believed they might. Michael P. Winship, "What Puritan Guarantee?," Early American Literature 47 (2012): 411-12.

7 "Declaration of Ministers of Massachusetts," in Collections of the Massachusetts Historical Society 5:1, 490-91. Notable for their connections to missionary projects in various capacities later in this chapter are John Eliot, Thomas Shepard, John Wilson, and Richard Mather, all of whom signed this declaration regarding clerical viewpoints on salvation and sanctification. This importantly establishes a baseline for consensus beliefs held amongst the above mentioned individuals. David D. Hall and Anne S. Brown observe that during this period only about twenty-five percent of parishioners owned the covenant, though it is important to remember that religious scrupulosity served as an important motive for abstention. Puritans were often genuinely uncertain about their state of grace and recognized the gravity of taking the sacrament in vain. Similarly, the diversity of Congregationalist practices ensured that some parishes practiced the Half-Way Covenant before it was formalized and promoted throughout the colony. Anne S. Brown and David D. Hall, "Family Strategies and Religious Practice: Baptism and the Lord's Supper in Early New England," in Lived Religion in America: Toward a History of Practice, ed. David D. Hall (Princeton: Princeton University Press, 1997), 52, 56-57.
} 
during this time, but Praying Indians attempted to navigate puritan ideas about proper conversion and their full acceptance as an Indian community among the English in the face of rising cultural tensions. As the colony lurched closer to open warfare against the Wampanoag, Praying Indians and the English closest to their communities faced the difficulty of proving their loyalties and commitments to the larger colony. They often did so by relying on their status as a covenanted body of "Praying Indians" which drew on the wider puritan understanding of a federal covenant and a network of churches to assert that they were spiritual kin to the English. Unfortunately, material concerns and suspicions of all Native Americans would override the claims of both Praying Indians and their missionary supporters to cultural and religious legitimacy.

\section{A Body of Visible Saints: Early Praying Town History}

Both John Eliot and Thomas Mayhew, Jr. envisioned religious conversion of the Indians as a project fundamentally linked to their successful adoption of English social customs within bounded towns. All ministers, even those most committed to the missionary project, viewed many aspects of native culture with condescension, if not outright disgust. ${ }^{8}$ The Protestant emphasis on sola scriptura also placed particular importance on a proper textual grounding and reflection on the Bible as a necessary requirement for spiritual growth, a language barrier which

\footnotetext{
${ }^{8}$ Neal Salisbury, Manitou and Providence: Indians, Europeans, and the Making of New England, 1500-1643 (Oxford: Oxford University Press, 1982), 178, 186-190. James Axtell, The Invasion Within: The Contest of Cultures in Colonial America (Oxford: Oxford University Press, 1985), 135-149. While earlier accounts by Salisbury and Axtell portray missionary sites as primarily an extension of cultural imperialism, recent works within this field assert that they were instead sites of religious contestations, despite the supposed weight which Europeans wielded in these exchanges. See Edward E. Andrews, Native Apostles: Black and Indian Missionaries in the British Atlantic World (Cambridge: Harvard University Press, 2013), 23. Linford D. Fisher, the Indian Great Awakening: Religion and the Shaping of Native Cultures in Early America (Oxford: Oxford University Press, 2012), 15-25. Julius H. Rubin, Tears of Repentance: Christian Indian Identity and Community in Colonial Southern New England (Lincoln: University of Nebraska Press, 2013), 28-36. In his 1670 account, Eliot insisted that missionary work would be difficult for English ministers, for "an English young man raw in that language, coming to teach among our Christian-Indians, would be much to their lost; there be of themselves such as be more able, especially being advantaged that he speaketh his own language, and knoweth their manners ... I have begun to teach them the Art of Teaching, and I find some of them very capable." Clark, ed., The Eliot Tracts, 401-02.
} 
both ministers sought to overcome by learning Algonquian dialects in order to preach among the Indians. Eliot eventually went even further with his translation of the Bible into Algonquian, along with various translations and original compositions to give Indian students a small library of texts. It was also a barrier that they expected Indian children to approach through schooling and catechesis, which promoted the English language within the Praying Towns that they formed. In a colonial environment, New England puritans also developed stringent requirements pertaining to church covenant and membership, formalized at the Synod of 1648, which plagued the formation of a visible Indian church throughout the early years of English missions. Wampanoags, Nipmucs, Massachusetts, and other Native Americans who joined early Praying Towns and sought to meet their English neighbors on a theological middle ground were the first to encounter the exclusivity of puritan religion in their efforts to forge a closer connection with them. The early ecclesiastical history of Praying Indian communities demonstrates both the adaptability of these communities, as they sought to dramatically change some aspects of their society to better conform to English expectations, and their tenacity in mastering English theological ideas and practices in the face of profound discrimination and skepticism within the colony at large.

In Eliot's account of his first efforts to preach to audiences of Massachusett Indians, published in England as part of The Day-Breaking, if not The Sun-Rising of the Gospel with the Indians of New-England (1647), he encountered the first major barrier to indigenous conversion in the form of language and understanding. Throughout the course of New England missions, this forced Eliot and other missionaries to innovate and modify their plans, in addition to ensuring a modicum of Indian control over the nature and reception of religious ideas. ${ }^{9}$ During

\footnotetext{
${ }^{9}$ See Joshua David Bellin's ““A Little I Shall Say': Translation and Intercutluralism in the John Eliot Tracts,” in Colin G. Calloway \& Neal Salisbury, eds., Reinterpreting New England Indians and the Colonial Experience
} 
the round of questions which Eliot fielded after his brief sermon, the Indians wanted to know if God was capable of hearing Indian prayers. After assuring the gathered community that God could in fact hear them for the better part of the day, Eliot and his companions agreed that the best way to demonstrate the truthfulness of their claims was to pray "in their owne language," which reportedly triggered profound weeping from the crowd. ${ }^{10}$ During his December 9, 1646 visit, Eliot noted that the gathered Indians offered up their children to be educated by the English, and that this prompted Eliot to begin "setting up a Schoole among them or very neare unto them," demonstrating once again an early Indian initiative which shaped English responses. ${ }^{11}$

Throughout the 1640s and 1650s, Indians who served as the founding members of Natick increasingly participated in the wider ecclesiastical and social activities of English settlement. In a discussion on religious spaces, Kathryn N. Gray suggests that a sermon delivered by Eliot in Algonquian before a mixed Indian and English audience at Cambridge in 1647 was part of the synod deliberations that produced the Cambridge Platform of 1648. Gray has aptly observed that this placed potential Indian converts squarely before the intellectual elite of the colony while highlighting the colony's failure to make missionary activity a priority before $1646 .{ }^{12}$ Nonantum and Natick Indians increasingly sought to strengthen their ties to English communities, most often by sending their children to live with the English in anticipation of reciprocity - a practice commonly utilized by Algonquian-speaking Indians. Thus, in this vein Waban had diligently sent his son to the English school at nearby Dedham in an effort to build rapport with the

(Boston: The Colonial Society of Massachusetts, 2003), 52-83. Bellin critiques Cogley's benign acceptance of Eliot's authority in explaining indigenous actions and motivations within the tracts, and highlights the important ways in which translation obfuscated Eliot's understanding and unmoored Christianity from its symbolic and conceptual grounding in the migration from English to Algonquian.

${ }^{10}$ Michael P. Clark ed., The Eliot Tracts: With Letters from John Eliot to Thomas Thorowgood and Richard Baxter (Westport: Praeger, 2003), 85, 91.

${ }^{11}$ Ibid., 99.

${ }^{12}$ Gray, John Eliot and the Praying Indians, 63-65. See also Clark, ed., The Eliot Tracts, 120. 
community. ${ }^{13}$ Anthony stressed during his public confession that he had initially sought to join the English to learn blacksmithing, and that this desire had given way to learning about Christianity once he heard about God at Nonantum after spending a year at Roxbury and understanding nothing at the English church. ${ }^{14}$ The Wampanoags at Martha's Vineyard similarly organized a community under a civil covenant and began a school for their children in partnership with Thomas Mayhew, which served about thirty children in $1651 .^{15}$

Despite these efforts, Indians who desired to forge a closer religious connection with the English faced opposition and discrimination from the colony at large, particularly in the arena of religion. If puritans were exclusive in their own admissions practices within the church, they proved even more willing to exclude Praying Indians. The tract Tears of Repentance (1653) chides its audience: "surely it were great uncharitableness, and derogatory from the glory of God, to think that none of these [Praying Indians] are truly changed." ${ }^{16}$ In A further Account of the progress of the Gospel (1660), Eliot had suggested that the principal leaders of the Praying Towns should "be seasoned in Church-fellowship, in communion with our English Churches" as a preparatory step to forming their own church covenant. The magistrates and ministers unanimously objected, preferring that Praying Indians should have their own gatherings and the English theirs, allowing Praying Indians to only occasionally join with them "for participation of the Seals, the Sacraments of Baptism, and the Lords Supper, and for any special Exercise of Discipline." For these events, the ministers stressed that Roxbury should be the sole religious location where Indian Christians and puritans rubbed shoulders. Eliot admitted that even in

\footnotetext{
${ }^{13}$ Ibid., 83.

${ }^{14}$ Ibid., 364-65.

${ }^{15}$ Ibid., 257. As David J. Silverman has shown, the isolation of the Martha's Vineyard community allowed for it to chart a divergent path from mainland communities. Here, the indigenous church "played a multivalent and principal role in offshore Wampanoag community life, reinforcing the Indians' village, tribal, and colonial ties, and providing an institutional framework in which to address issues often unrelated to religion." Silverman, "The Church in New England Indian Community Life," 265-67.

${ }^{16}$ Clark, ed., The Eliot Tracts, 254.
} 
Roxbury there were some objections to allowing Indians into their religious body, but that debates on Indian membership and the public confessions of the Praying Indians silenced the objectors. ${ }^{17}$ In the early years of missionary activity, exclusion and religious segregation appear to be the preferred stance of most Englishmen.

Missionary tracts published from 1647 to 1651 serve to highlight the tremendous pace of progress accomplished by Eliot and Mayhew's early efforts, an optimism tempered after the first examination of Eliot's converts before English ministers and magistrates described in Strength out of Weakness (1653). In The Clear Sun-Shine of the Gospel (1648), Eliot stated that the English and Indians were the same except for two principal differences: the English knew and served God and they also "labour and work in building, planting, clothing our selves, \&c. and they doe not: and would they but doe as wee doe in these things, they would be all one with English men." This statement comes across as ethnocentric today as it probably did to Eliot's audience, especially in discounting the homes that Indians built, the crops that they raised, and the clothes that they produced, but the emphasis of Eliot's point was also equally clear: the English expected Indians who entered into this new religious arrangement to adopt their practices. In this vein, Waban and other leaders had already established new English-style rules that they expected their followers to adhere to, and the men had already cut their hair in the face of scorn for doing so from traditionalists who were uninterested in Eliot or his message. ${ }^{18}$ While Indians had been present at English church meetings on Sundays and had joined the Roxbury church in limited numbers before 1650, they also complained to Eliot that when they came to

\footnotetext{
${ }^{17}$ Ibid., 360-361.

${ }^{18}$ Ibid., 98-99, 124. In a private letter, Eliot again stressed that English civility necessarily preceded ecclesiastical admission: "... and prepare them for holy church covenant whereby they give up themselves to be governed by the Lord ecclesiastically... but I shall walk by good advice before I do this.” J. Rendel Harris, Three Letters of John Eliot and a Bill of Lading of the Mayflower. Reprinted from "The Bulletin of the John Rylands Library Vol. 5, Nos. 1 and 2, August, 1918- March, 1919 (Printed for Private Circulation, 1919), 6.
} 
English meetings they did not understand the sermon and proceedings, prompting Eliot to urge them to meet together instead. Eliot decided that "the wisest and best men [should] pray, and then to teach the rest such things as I had taught them from Gods Word, as well as they could," continuing this process with a second and third teacher and then a round of questions. $\mathrm{He}$ instructed these ersatz ministers to remember any question they were unable to answer and to deliver them to him upon his return. ${ }^{19}$ Again, necessity forced Eliot to adapt and to leave Indians with a great degree of latitude to develop their theology and practices as they wished. At the same time, the linguistic barrier placed Indians on a divergent path from their English brethren that would culminate in an autonomous Indian church rather than an integrated church polity within Roxbury or neighboring English towns.

To an English audience, the early years of Indian missions appear to have begun with a great degree of success, though Eliot stressed in The Light Appearing More and More Towards the Perfect Day (1651) that progress was necessarily slow for want of funding and provision from England and the part-time nature of his missionary work, which divided him between duties to nearby Indians and his Roxbury congregation. ${ }^{20}$ Eliot believed that the Indians should first build an English-style community before attempting to form a visible church, which led him to search with Indian leaders for a suitable site to construct their first model town. Carved out of property from neighboring Dedham, Natick developed as a hybrid Indian and English settlement, with a meetinghouse that served as Eliot's home when he visited the community, and a sturdy footbridge that crossed the river within the town. Future English observers commented extensively on the superb construction of the bridge and Indian prowess in constructing the building with minimal instruction from an English carpenter. This new community was not

\footnotetext{
${ }^{19}$ Clark, ed., The Eliot Tracts, 125. Charles M. Ellis, The History of Roxbury Town (Boston: Samuel G. Drake, 1847), 29-31.

${ }^{20}$ Clark, ed., The Eliot Tracts, 198.
} 
without opposition, described at length in the previous chapter in a familial context, as the sachem Cutshamoquin expressed his initial opposition to the founding of Natick, telling Eliot "that all the Sachems in the Countrey were against it." ${ }^{21}$ Eliot and the Indians who gathered at Natick took comfort in their decision in the face of opposition when an outbreak of smallpox during the winter of 1650 decimated their critics while only killing three Praying Indians. ${ }^{22}$

In Strength out of Weaknesse (1652) Eliot again admitted to adapting his plan for the community when he abandoned the notion of installing an English schoolmaster to teach their children in favor of an Indian teacher, later named in the Indian confessions from Tears of Repentance (1653) as Monequassun. Monequassun opened his lessons with prayer and then exercises in a short catechism which Eliot composed in Algonquian to teach the children both writing and reading. Reflecting on his aspirations at this point, Eliot stated that he intended "to traine up both men and youths, that when they be in some measure instructed themselves, they may be sent forth to other parts of the Countrey, to train up and instruct others." ${ }^{23}$ Eliot appears to have recognized that the most effectual means of religious instruction was a sort of "trickledown" approach where he and other ministers would supervise the instruction of capable Indian ministers, who would in turn instruct others with the added benefit of their linguistic grounding in Algonquian. In order to enforce this religious instruction within the larger polity Eliot gathered a great meeting at Natick and proposed that the community divide itself under the leadership of a ruler of one hundred and two sub-rulers of fifty, and then rulers of ten in

\footnotetext{
${ }^{21}$ Ibid., 201-03. John Wilson marveled that the house was built with only minimal aid from an English carpenter for one or two days (231-32) John Endecott also called their carpentry "remarkeable" and noted that Natick residents also constructed a fort and a sturdy footbridge (243). Finally, Richard Mather also commented on the innate aptitude of the Natick Indians in their carpentry and suggested that they might one day show the same aptitude in matters of religion (266-67).

${ }^{22}$ Ibid., 221.

${ }^{23}$ Ibid., 225.
} 
accordance with Exodus 18, formalizing the town's polity with a covenant to follow God's civil orders. $^{24}$

Eliot immediately followed this development in Strength out of Weaknesse by laying out the next task in his project: "to prepare them for Church-estate, to which end I doe instruct them, that the Visible Church of Christ is builded upon a lively confession of Christ, and Covenanting to walke in all the Administrations of the publique worship of God." ${ }^{25}$ By 1653, the civil and ecclesiastical history of Natick had developed largely in line with many New England communities. Though a good number of towns had formed a visible church almost immediately after their founding, this pattern was not entirely uniform throughout New England. The citizens of Roxbury waited two years before gathering a church, and the dissenting community of Northampton, Connecticut waited almost five years to hire a minister, and three more to form a church under the ministration of Eleazer Mather. ${ }^{26}$ In this tract, Eliot recounted his first public demonstration of the piety of the Natick community during a visit by Governor John Endicott, Boston minister John Wilson, and other notable leaders. Endicott and Wilson observed the physical development of Natick as well as the behavior of the community, judging the progress to be far more impressive than they initially expected. Upon hearing Eliot's sermon (in

\footnotetext{
${ }^{24}$ Ibid., 226-27. Eliot firmly believed that this was the proper organization of all civil societies, using the same model as the template for his vision for revolutionary England in The Christian Commonwealth. John Eliot, The Christian Commonwealth: or, The Civil Policy Of The Rising Kingdom of Jesus Christ (1659), 5-7. Going a step further in his Communion of Churches, Eliot afforded such power to synods that the most eminent scholar of Eliot, Richard W. Cogley, contends that he was likely converted to the Presbyterian position in form, if not name. See Richard W. Cogley, “A Presbyterian in Congregationalist New England?" Journal of Presbyterian History 77 (1999): 71-73, 78.

${ }^{25}$ Ibid., 227.

${ }^{26}$ Ellis, History of Roxbury, 22-23. Gura, "Preparing the Way for Stoddard," 241. The only comprehensive examination of New England's civil and ecclesiastical covenants is David A. Weir's Early New England: A Covenanted Society. Through an exhaustive analysis of covenants, Weir drew a number of significant conclusions: civil covenants varied in language significantly and reflected the experimental nature of colonial settlement. Native American covenants like the civil ones developed for Natick contained strong Christological statements that are typically absent in English civil covenants. Church covenants were important ecclesiological constructs which often took "weeks, months, and years" to hone. Though wording varied, these ecclesiastical covenants demonstrated a surprising unity in thought and theology. David A. Weir, Early New England: A Covenanted Society (Grand Rapids: William B. Eerdmans Publishing Company, 2005), 3-9, 137, 170.
} 
translation) and the questions which the Natick community raised in response to Eliot's words, Wilson wrote that he felt urged to speak to them with Eliot translating, "warning them of the great danger if they should decline from what they had already come unto, either in their knowledge, affection, or Christian practice, incouraging them against what might dampe or deterre." 27 Wilson's reference to the consequences of reneging on the covenant that the Indians had previously established with God in civil affairs is significant in light of the long period of time between polity formation and visible church formation in Natick's early history. ${ }^{28}$

In Church Government and Church Covenant Discussed, Richard Mather used "Turkes" and "Indians" as examples of groups who were "not fit materials for such as building as a Church of God, which is the house of the living God." Mather continued to stress the gravity of the "solemne Covenant" in light of Israel's idolatry and God's punishment, drawing on the biblical story of Achan in the Book of Joshua to argue that his failure to destroy all of the Canaanite cities the Israelites attacked "was the sinne of all the Congregation, and brought judgement upon them all." ${ }^{29}$ Likewise, the ministers of New England would be responsible for any failure to maintain high standards of church membership because their approval of the Natick congregation fell within their duties under church covenant. To Congregationalist ministers like Wilson this proved to be a serious consideration. The insistence that Indians prepare themselves adequately for church covenant after numerous unsuccessful demonstrations paved the way for preparation to enter mainstream puritan theology in the later debates surrounding the Half-Way Covenant in 1662. Similarly, the application of this gradual approach

\footnotetext{
${ }^{27}$ Clark, ed., The Eliot Tracts, 233.

${ }^{28}$ While recent scholars of the Praying Indians such as Julius H. Rubin have recognized that the Puritan ministers who examined the Praying Indians at this juncture deferred their ecclesiastical covenant because they believed that those examined failed to marshal sufficient evidence of their salvation by grace, it is worth noting that the consequential nature of the covenant and the religious connections forged when an established religious body authorized the creation of a new one certainly bore an overwhelming influence in their minds. Rubin, Tears of Repentance, 60-63.

${ }^{29}$ Richard Mather, Church Government and Church Covenant Discussed, 87, 89-90.
} 
to conversion in an Indian context served to legitimate preparation within the English themselves and the second generation of New England puritans.

Progress within the Natick community convinced Eliot that they were adequately prepared to form a covenanted church in 1653 , so he invited a group of colonial ministers which included Richard Mather and John Allin of Dedham to travel to Natick and observe the piety of the town's leaders. From the outset, the inability of Thomas Mayhew and other capable translators to attend the gathering hampered the confessions because this forced the ministers to rely solely on Eliot's translations and caused the meeting to stretch on throughout the day as Eliot worked through the laborious task of translation by himself. In the introductory material to the printed confessions, Richard Mather observed that the actions and confessions of the Praying Indians "may justly be looked at (if not as a full and through Conversion, yet) as an hopeful beginning and preparation thereto, if the lord be pleased to go on with what he hath begun." ${ }^{30}$ Anticipating that his English readers might question why the Praying Indians were not gathered into a visible church at this point, if grace was so apparently evident, Mather compared their developments with the building of Solomon's temple as a slow spiritual process that necessitated caution. If Praying Indians were "to be invested with all Church-power as a Church when yet they are not furnished with any to be an able Pastor and Elder over them" for guidance, then they ran the risk of deviating from orthodoxy. By prematurely validating their covenant, New England's ministers would also be complicit in this wrongdoing and would face God's wrath. ${ }^{31}$

Eliot observed that the Praying Indians had "for some years inquired after Church-Estate, Baptism, and the rest of the Ordinances of God, in the observation whereof they see the Godly English to walk," which illuminates the desire of Indian Christians to achieve a degree of parity

${ }^{30}$ Clark, ed., The Eliot Tracts, 264.

${ }^{31}$ Ibid., 265. 
in religious matters with the English and to gain acceptance within this cultural arena. The ritualized nature of baptism and the Eucharist also probably held great appeal to Praying Indians as methods to ward off physical harm, in keeping with traditional native religious beliefs. To prepare them for the examination process Eliot coached them on the proper means of confession "of their former sins, and of their present knowledge of Christ, and experience of his Grace," which Eliot took down and read before the ministers gathered at Natick. ${ }^{32}$ The confessions recorded in Tears of Repentance follow the same general format, which illuminate key points marked by Eliot in his coaching: they begin with a description of walking in sinful ways, the moment when each Indian first heard the English message, vacillation between anger and understanding, and steps to practice these admonitions in the face of failure and backsliding. Upon reading each confession, some ministers offered additional questions for the confessors or expressed their opinions: John Allin asked Totherswamp how he found the current state of his heart on matters of repentance, and John Wilson judged Waban's oratory lacking because of his tearful breakdown as he delivered his confession. ${ }^{33}$ By the time Natick's schoolmaster Monequassun delivered his confession, the crowd had become listless in waiting for translations, as "many of them went forth, others whispered, and a great confusion was in the House and abroad," and the ministers decided to defer a decision on church membership "to a more fitting time," citing the lack of other translators who could verify Eliot's accuracy. ${ }^{34}$ A covenanted Indian church did not form in 1653 because of the language barrier and hesitation on the part of the gathered ministers to acknowledge that the Praying Indians were adequately prepared

\footnotetext{
32 Ibid., 268.

${ }^{33}$ Ibid., 269-72. Rubin contends that this emotionalism was another potential drawback to the ministers, as the confessions which fully satisfied them in 1659 "appear to be formulaic and devoid of the holy desperation, grieving, tears, and outcries that marked the initial religious experiences" of the previous Eliot Tracts. Rubin, Tears of Repentance, 67.

${ }^{34}$ Clark, ed., The Eliot Tracts, 279, 282.
} 
theologically and capable of autonomy under a covenant, despite the significant changes to civil polity observable in Natick. This renewed emphasis on long-term preparation would have implications for the Half-Way Covenant and the legitimation of gradual sanctification within New England as a whole.

\section{Praying Indians, Theological Preparation, and the Half-Way Covenant}

Despite Eliot's initial millennial optimism, the realities of intercultural communication and formidable linguistic barriers necessitated that theological instruction progress slowly within Praying Towns after 1653. After the failed examination of his candidates, Eliot recognized that New England's ministers proved more hesitant to recognize civil and religious advancements within the Praying Towns as commensurate. This high profile example of theological preparation in the context of missions, along with the successes publicized by Eliot and Mayhew, established the viability of long-term, gradual conversion in opposition to puritans who hoped to keep the boundaries of church community tightly closed to all but confirmed "visible saints. Commenting on the early success of his 1646 religious instruction of Indians in The Day-Breaking, if not The Sun-Rising of the Gospel with the Indians of New-England, Eliot envisioned the slow progress that he foresaw: "as in nature there is no progresses ab extreme ad extremum, so in religion such as are so extreamly degenerate, must bee brought to some civility before religion can prosper." Rooting Indians in the landscape that puritans had come to inhabit, Eliot reminded his English audience that some had been credulous that "English graine would grow, or that the Plow could doe any good in this woody and rocky soile," but time had brought great success in planting the New England settlement. 
Optimistically, Eliot concluded that similar successes lay in the future with Indian conversion with time so long as the adoption of English culture and customs of dress, economic practices, and mannerisms progressed accordingly. ${ }^{35}$ Yet the adoption of English civil culture only partly satisfied the expectations of New England's wider ministerial body. After failing to satisfy the colony's ministers during the public confessions of 1653, Eliot and Mayhew deferred attempts at examination in favor of more nuanced theological instruction and confessional practices. Theological preparation developed into a distinctly Indian morphology of conversion that adopted aspects of the standard puritan model but accounted for the cultural differences between Indians and Englishmen, which eventually brought them success in confessions delivered in 1659. Though rarely explicitly cited as a defense in favor of the Half-Way Covenant, the connections of various supporters of the Covenant with the colony's missionary project ensured that indigenous conversion served as a tangible example of preparation in practice. They also forced puritans to consider the nature of church covenants and the ability of people - English or Indian - to meet their stringent requirements.

After the first failed examination, Eliot deferred a subsequent display of Indian piety until 1654 in order to better prepare the Natick community. He recognized that the lack of additional translators had hampered the first exam, as did the notion that it could be conducted within the span of a single day, so he moved for a longer and more thorough examination, which New England's ministers decided to hold at Roxbury. At the same time, Eliot and the leaders of Natick grappled with community politics, as the death of Cutshamoquin brought Josias to the sachemship and led a faction of Natick residents to split and form their own community at Punkapoag. Though Eliot preferred a single community of Praying Indians, he accepted this split and noted that Indians planned to form additional communities as well. In another divisive

\footnotetext{
${ }^{35}$ Ibid., 93.
} 
moment, a group from Nonantum took Totherswamp's son aside and got him drunk on liquor in order to sabotage the upcoming examination. Even more egregiously, one of the saboteurs was an assistant to Eliot who helped him in translating the Bible. ${ }^{36}$ Nevertheless, Indians and puritans gathered at Roxbury in April 1654 to conduct a second examination of eight leading converts from the Natick community.

For this second day of examination, or natootomuhteáe kesuk, as the Praying Indians named it, New England's ministers subjected the examined to a series of freeform questions, which covered a range of theological topics, including God's nature, sin and its effects, the fall of man, and the significance of religious belief. Eliot, Mayhew, and two others served as translators and scribes in the exchanges, agreeing by and large on the accuracy of the translations, though Eliot and Mayhew did clash on the translation of hohpoóonk as "humility."37 After the examination, Eliot writes in A Late and Further Manifestation of the Progress of the Gospel Amongst the Indians in New England (1655) that the elders who conducted the test were pleased with the ability of the Praying Indians to explain "how far the Lord hath let in the light of the good knowledge of God into their soules, and what tast they have of the Principles of Religion, and doctrine of salvation." 38 This complemented the previous examination, which sought to demonstrate the experience of knowing God and repentance, yet it still failed to satisfy the colony's minsters that the Praying Indians were adequately prepared to adopt a church covenant. Chastened yet again, Eliot reiterated that it was a grave matter to entrust the

\footnotetext{
${ }^{36}$ Ibid., 304-07. In yet another showing of the measures taken at Natick to adopt English civil rules, Totherswamp and Natick's Indian Court had the men whipped and put into the town's stockade as punishment. Totherswamp punished his son himself by whipping him in front of his classmates at the town's school.

${ }^{37}$ Ibid., 308-317. Eliot stressed in this tract that the questions were delivered in a flexible style rather than the scripted nature of catechesis which children typically followed. The purpose of this examinational mode was to elicit thoughtful response rather than rote mimesis of the catechism. In a private letter, he stressed that he had hoped that this would method would provide "the fuller satisfaction given to all that desired the same." In the same letter he also reiterated the ecclesiastical developments unfolded slowly in Natick, but that the indigenous ministers closely followed his counsel. Harris, Three Letters of John Eliot, 10-11.

${ }^{38}$ Ibid., 318.
} 
community with such a covenant when they "have so little knowledge and experience in the ways of Christ, so newly come out of that great depth of darknesse, and wild course of life." To Eliot, the precedent set by the formation of the first true Indian church would set the tenor of Indian conversion in the future, so he again deferred to the judgment of the colony's ministers and to God's timing, reinforcing the importance of theological preparation. ${ }^{39}$

Given the gravity of the adoption of an ecclesiastical covenant and the importance of spiritual fidelity, it is no surprise that puritans stressed caution in granting this status to Praying Indians. By adopting Indians into their spiritual family, they joined each other in a shared fate. To further prepare the Praying Indians for church covenant, Eliot continued the work of translating the Bible into Algonquian along with a number of other devotional works, which fostered autonomous piety as the reader engaged with the text. By 1658, Eliot had translated Abraham Peirson's catechism as Some Helps for the Indians Shewing Them How to improve their natural Reason, which offered explanations for the origins of the world, the nature of God, and his sovereign punishment of $\sin .^{40}$ At the same time Praying Indians faced a number of trials, including the death of Thomas Mayhew, Jr. at sea and uncharacteristic raining and illnesses that spread throughout the Praying Towns, which prompted Eliot to institute a series of fasts and exhortations from Indian ministers and trusted laymen. Their sincerity greatly affected Eliot's son, who had not been present for a fast before. The exhortations, recorded by Eliot in that year's tract, also serve to demonstrate an Indian understanding of puritan theology. It is no surprise that all of the brief sermons emphasize the cause-and-effect relationship between sin and God's punishment, along with the need for repentance to avert his wrath. ${ }^{41}$ It is also worth emphasizing

\footnotetext{
${ }^{39}$ Ibid., 318-19.

${ }^{40}$ Abraham Peirson, Some Helps for the Indians Shewing Them How to improve their natural Reason, To know the True GOD, and the true Christian Religion (Cambridge: Samuel Green, 1658), 7, 23, 26.

${ }^{41}$ Clark, ed., The Eliot Tracts, 332-39.
} 
the complementary relationship between gods and humans across Indian and English religion, as both stressed service and adherence to proper rituals in order to avoid negative repercussions. While it is almost impossible given the documentary record to determine the exact nature of Praying Indian religious belief during this period, the link between sin and repentance suggests that they viewed their relation with the English god much as they did the manitou of the Algonquian cosmos.

In the introduction to the 1660 tract entitled A further Account of the progress of the Gospel Amongst the Indians In New England, Joseph Caryl contrasted the faith of Praying Indians with the majority of Christians in England. Such comparisons between "noble savages" and degenerate Englishmen were by now standard tropes in writings about North American experiences, but this was new in the sense that it portrayed Praying Indians as true believers and Englishmen as complacent in their faith. Caryl's introduction contrasted the significant developments within Natick and the other Praying Towns with Englishmen "who have been born and bred up in the aire and sound of the Gospel all their dayes." It was rare to find a person in England, he complained, who was "able to give any passable account of their conversion to God." Still more took offense to the adoption of the New England Way and a required conversion account for full membership and communion. In publishing the final confessions of the Praying Indians, which culminated in the creation of an indigenous church covenant, Caryl hoped that "the practise and example of our native Brethren, yea, of the native Indians in New England might kindle in us the fire of a blessed emulation in this matter." Preparation following the model implemented within the Praying Towns would result in churches that were "beauties of Holiness, and the fruits of the presence of Christ would be more gloriously visible in them."42 For the English branch of the Corporation, and for many of New England's ministers, the ability ${ }^{42}$ Ibid., 359. 
of Praying Indians to pass their final test and to join them in full ecclesiastical communion signaled a new degree of acceptance for Praying Indians as well as an explicit affirmation of theological preparation as a conversionary model, which would inform future debates surrounding the Half-Way Covenant.

\section{Half-Way Covenant Debates and Indian Implications}

The issues which contributed to the development of the Half-Way Covenant were rooted in both religion and demography. Religiously, ministers grappled with the tension of the longstanding practice of infant baptism and the puritan insistence that adults give an account of a conversionary experience as the first step before owning the covenant as a full member.

Demographically, the colony experienced growth from external immigration and the birth of a new generation of children to New England's first settlers, both of which did not possess the conversionary accounts necessary for full church membership. ${ }^{43}$ While some ministers hewed to the strict criteria of membership outlined in works like Mather's Church Government and Church Covenant Discussed, others promoted a model where children and the unchurched would enter the church as nominal members as a first step in a process of sanctification. Thus, the HalfWay Covenant itself reinforced the preparational model of sainthood over the instantaneous conversions of the founding generation to foster the conditions conducive to conversionary experiences. While the Half-Way Covenant of 1662 served as a panacea for problems that the older generation of puritan ministers saw in the colony as a whole, the expansion of baptism and church membership to a wider body within puritan communities held profound implications for

\footnotetext{
${ }^{43}$ Katherine Gerbner outlines this use of the Covenant to reach the unchurched through an examination of the Cambridge community and the baptismal practices of Reverend Jonathan Mitchel in reaching out to the unchurched. Katherine Gerbner, "Beyond the "Halfway Covenant": Church Membership, Extended Baptism, and Outreach in Cambridge, Massachusetts, 1656-1667," New England Quarterly 85 (2012): 290, 298.
} 
the inclusion of Praying Indians within New England's religious body. ${ }^{44}$ In the years following the confirmation of the Boston Synod's decisions by the colonial government, ministers debated the merits of the Covenant and its historical legitimacy and future effects on the spiritual health of the colony. At stake in these debates was the acceptance of preparation as a legitimate mode of conversion, which directly affected Praying Indians and their reception within the wider ecclesiastical body of New England. After King Philip's War, the theological innovations of Solomon Stoddard would fully realize this new trajectory of puritan theology and internalize conversion as a gradual process. The theological foundation of preparation in Indian missions is most notably apparent in the actions and strategies of the New England Company and missionary writings to the English directors of the Company throughout this period.

While the debates surrounding the Half-Way Covenant primarily concerned the state of salvation for the children of the colonists, the theological shift towards an internalized state of grace and the opening up of sacraments to a wider body within the colony held profound implications for the inclusion of Praying Indians within the greater ecclesiastical polity. In his Farewel Exhortation sermon of 1657, the eminent New England minister Richard Mather warned of the dangers facing the rising generation of puritans in the colony as they grew up and failed to own the covenant. At one point in the sermon, Mather drew on the illustration of Indian childrearing to chastise his congregation for neglecting their own children when they should be even more attentive to raising them than "Pagans \& Infidels would do for the soules of theirs." He again relied on the trope of the unconverted pagan, suggesting that children who reneged on

\footnotetext{
${ }^{44}$ Adam Seligman contends that New England ministers' emphasis on institutional grace and the creation of tightknit communities broke down in the second generation, which faced a variety of economic problems and new community dynamics as settlements expanded. Thus, the Half-Way Covenant and later developments under Solomon Stoddard were efforts to redefine community boundaries by admitting everyone to the church and internalizing grace. Seligman, "Inner-Worldly Individualism," 541, 544-46. Seligman does not consider the implications of this shift to a more internalized understanding of grace and the status of Praying Indians, which this chapter and the next one seek to explore.
} 
the covenant established by their infant baptism faced "the sorer and more dreadfull judgments, as breach of Covenant hath ever done" in comparison to the wrath that the unconverted faced. Backsliders should resign themselves to a fate "farr worse, their sins being against more mercy and being violations of the Covenant, which was confirmed \& sealed in their Baptism." 45

By approving the Half-Way Covenant, colonial magistrates created a breach within the network of New England churches that was slow to heal. At stake was the scriptural basis for theological preparation, and obliquely, the potential for Praying Indians to join the colony as full members of its religious body. John Davenport offered one of the most scathing critiques of Covenant in a 1663 essay, which argued against infant baptism of the third generation of puritans and the authority of the Synod to implement this practice throughout the colony. In making the case that "infants are not capable of personal church-membership" and that excommunication removed all members of a family from church membership, Davenport drew on the illustration of a "Turk" who was English by birth, but baptized as a child. Davenport argued that the "Turk" was born into an Islamic lineage and that "to say that Turks are Members of the Church of Christ is in truth to speak Daggers."46 This insular view of covenant membership excluded all but the founding members of the New England colony, as Davenport pressed the point that the covenant required maintenance through succeeding generations, and that a breached lineage was essentially irreparable, so the application of baptism and other sacraments to unbelievers was a grievous sin. By drawing upon such restrictive requirements for church membership, Davenport's view of church covenants essentially excluded Indians who, as part of the "lost tribes of Israel," fell under the category of “Abraham's Children” who lost their covenant

\footnotetext{
${ }^{45}$ Richard Mather, A Farewel Exhortation to the Church and People of Dorchester in NEW-ENGLAND (Cambridge: Samuel Green, 1657), 10, 12.

${ }^{46}$ John Davenport, Another Essay for Investigation of the Truth, in Answer to Two Questions, concerning (a) The subject of Baptism. (b) The Consociation of Churches (Cambridge, 1663), v-vi, 23. See Scheick, "An Inward Power and Authority," 2.
} 
membership. If viewed as gentiles, this still provided an opportunity for them to form a covenant, but Davenport's restrictive and cautious view insisted that New England's ministers take seriously the charge "to keep out the Heathen uncircumcised in flesh who never were Members. ${ }^{47}$ Finally, Davenport argued against the Covenant's clauses on synods for fear that this might force ministers to carry out directives that contradicted scripture, instead arguing "the manner of their communion must be social, as between equals, none exercising jurisdiction and authority over another" as a defense of Congregationalist autonomy. ${ }^{48}$ While not directly aimed at the Indian churches founded at Natick and Martha's Vineyard, it is possible that the presence of autonomous Indian churches amplified Davenport's fear of synodic corruption, for in theory they held equal status and weight within such deliberations. Thus, the tenuous beginnings of Natick's church could potentially impact the entire colony negatively if colonial authorities granted Indian ministers equal standing and influence over the theological dictates for the colony. Similarly, the notion that Indians might surpass their English neighbors in piety gave cause for unease.

Richard Mather offered a direct rebuttal to Davenport's tract, entitled A Defence of the Answer and Arguments of the Synod Met at Boston in the Year 1662, which critiqued Davenport's restrictive view of baptism by arguing that the synod meant to only baptize "Children of All that are named Christians," and that this was "farre neerer the Rule and Mind of Christ" than to baptize no Children - a position akin to Anabaptism. Mather also rejected the restrictive notion that excommunication applied to the children of parents who had sinned in such a grave manner, and that Davenport himself had offered no objections to the principal of synods articulated in the 1648 Cambridge Platform, drawing on John Cotton's writings to defend

\footnotetext{
${ }^{47}$ Ibid., xi-xiii, 19.
}

${ }^{48}$ Ibid., 7 . 
his position. ${ }^{49}$ Within his tract, Mather explicitly defended sanctification as a gradual process, marked by a temporal distance between the beginning of faith and the maturation of religious belief. In his defense, he cited the biblical practices of Jesus's disciples and their administration of baptism and communion. Mather similarly recognized the spiritual benefit of the covenant, along with baptism, prayers, and the blessing of the church, "to excite them [converts], and encourage them to, and in good, and to reclaim them from evil." Within Mather's conception, the church's supporting role was of the utmost importance and outweighed any desire to harshly restrict membership to covenanted adults. ${ }^{50}$ Similarly, in his Church Membership of Children, and Their Right to Baptisme, Thomas Shepard argued that "it is a miserable mistake to think that inward reall holiness is the only ground of admission into Church-Membership... but it is federal holiness, whether externally professed as in grown persons, or graciously promised unto their seed. ${ }^{" 51}$ Shepard also recognized that membership within the church consisted of a series of stages, and that the standard examination which characterized the "New England Way" was "indeed required of all those members who should partake of the Lords Supper, but it is not required (as you seem to say) of every one to make him a member" because of the lineage established by the federal covenant. ${ }^{52}$

According to this conceptualization of salvation and the church covenant, Praying Indians had accomplished the requisite steps necessary for preparation into the formal covenant and had established their own federal covenant in accordance with mainstream puritan thought. By recognizing them as true members, New England's ministers had carried out their appropriate

\footnotetext{
${ }^{49}$ Richard Mather, A Defence of the Answers and Arguments of the Synod Met at Boston in the Year 1662 (Cambridge, 1664), xi, xiii-ix, 99-100. The numbering of this tract is inconsistent, so for the sake of clarification I have labeled the first sequence of numbers with roman numerals to denote their introductory status within the overall document.

${ }^{50}$ Ibid., xxiii, 11.

${ }^{51}$ Shepard, Church Membership of Children, 13.

${ }^{52}$ Ibid., 17.
} 
duties and had validated Praying Indians as a godly people within the ecclesiastical body of the colony. That these issues were somewhat linked is apparent in the fact that Eliot and Danforth implemented the Half-Way Covenant in the fall of 1658 and the final Praying Indian examination occurred in the spring of $1659 .{ }^{53}$ In the only direct reference to Indians within the text, Shepard drew on the example of Indian children adopted by Englishmen in the colony, presumably after disease epidemics had wrought their destruction on Indian communities, arguing that their godly instruction merited their reception into the church covenant, as Abraham did with his servants in Genesis 17. Even in lineages that extended beyond direct bloodlines, Shepard argued in favor of a strong federal covenant, which again serves obliquely to elevate the status of Praying Indians who owned the covenant by their own accord. ${ }^{54}$

Entering the polemical fray with his own defense of the Covenant, John Allin also highlighted the continuity between the 1662 decision and the 1648 Cambridge Platform, arguing that all of these decisions were in line with puritan divines such as Thomas Hooker, and that membership began in childhood and matured once young adults owned the covenant. ${ }^{55}$ Drawing on the example of the "Primitive Churches" created by the Apostles, Allin argued that the repentance of the gentiles made them "Believers in Ecclesiastical account," and set them in opposition to the "Infidels and Unbelievers" who were "both opposed to Believers." Relating this example to the fifth proposition of the 1662 platform, which stated that minority church members who had grown to be reputable church members should have their children baptized, Allin argued that the parents of this proposition must marry a believer to avoid becoming

\footnotetext{
${ }^{53}$ Robert G. Pope, The Half-Way Covenant: Church Membership in Puritan New England (Princeton: Princeton University Press, 1969), 32-33.

${ }^{54}$ Ibid., 12-13. Shepard reinforced this position by stating that "which sort of servants in these dayes may as well be admitted to Church-membership, without fear of defiling the Church, as their masters themselves."

${ }^{55}$ John Allin, Animadversions Upon the Antisynodalia Americana, A Treatise Printed in Old England: In the Name of the Dissenting Brethren In the Synod held at Boston in New England 1662 (Cambridge, 1664), 3, 38. Allin defended the sixth proposition of the 1662 Covenant specifically.
} 
"unequally yoked." ${ }^{56}$ By Allin's reasoning, Praying Indians would fall within a subset of Indians who had owned the covenant and grafted themselves to the covenanted lineage of the New England colony, and their children would enjoy such privileges of church membership. Despite this brief aside which pertains indirectly to Indians, Allin's text primarily focused on the issues imperiling the English element of the colony.

\section{Indigenous Preparation and Oxenbridge's "Conversion of the Gentiles"}

An unpublished manuscript treatise attributed to John Oxenbridge in 1670 represents the clearest contemporary emphasis on preparation in indigenous missions and the most complete and systematic attempt to advocate not only for New England missions, but also for a recognition of a long-term mode of conversion in the face of objections to the project. Oxenbridge had traveled from England to the Caribbean, spending time in Suriname and Barbados before returning home, where he ran afoul of the Anglican establishment and immigrated to Boston in 1670. That same year he also authored A Seasonable Proposition of Propagating the Gospel by Christian Colonies in the Continent of Guaiana: Being Some Gleanings of a Larger Discourse Drawn, But Not Published, which adds credence to his authorship of "Conversion of the Gentiles" as a larger and unpublished discourse dedicated to evangelization. ${ }^{57}$ A close reading of Oxenbridge's response to objections against indigenous missions provides an important sense of common arguments levied against missions by skeptical New England ministers and laity

\footnotetext{
${ }^{56}$ Ibid., 51-52. Allin specifically singled out "Heathen, Indian, or like Infidel" in the category of those to avoid marrying, declining to include or differentiate Praying Indians within this subset. The most plausible reading of this text, in light of preparational theology and its influence on the Covenant, is that Allin considered the Praying Indian communities to be true believers, despite his later conflict with the communities over town boundaries. For the text of the Covenant, along with the ministerial arguments against the fifth proposition and their collective answers, see Williston Walker, The Creeds and Platforms of Congregationalism (New York: Charles Scribner's Sons, 1893), 328.

${ }^{57}$ John Oxenbridge, A Seasonable Proposition of Propagating the Gospel by Christian Colonies in the Continent of Guaiana: Being Some Gleanings of a Larger Discourse Drawn, But Not Published (London: 1670).
} 
throughout the colony, and the objections which Oxenbridge anticipated from his English readership. It is also an important outsider's view on the efficacy and nature of indigenous conversion.

Structurally, Oxenbridge began his treatise with an introduction on the imperative for gentile conversion, followed by eight chapters which systematically cull the bible of scriptural imperatives to convert gentiles in order to demonstrate irrefutably that Indians were among God's chosen people and required conversion to actualize millennial eschatology. ${ }^{58}$ In the introduction, he declared that even though Protestant churches had cooled in their evangelical fervency, prophecy in Revelation 5:9 ensured that God would establish indigenous churches among the Elect within their wider population. ${ }^{59}$ In the second chapter, Oxenbridge proposed that the Indians of North America descended not from Shem, but from Japhet (and thus, gentiles), which placed them under God's providence in Genesis 9:27: “Thus our Indians are in ye compasse of this first promise being Japhet's enlarging and so ye object [to the] greater blessing yet attend's it." 60 Oxenbridge also insisted that North America contained a number of unreached indigenous groups, which needed evangelization as part of God's promise to spread the gospel, even if they had rejected him during their ephemeral past. ${ }^{61}$ Throughout his examination of Old Testament prophecies, Oxenbridge consistently highlights the providential nature of conversion in order to place puritans within this prophetic vein.

The eighth chapter importantly considers examples of typological connections in the New Testament, while the ninth chapter begins a slight thematic shift through a consideration of

\footnotetext{
${ }^{58}$ Topically, each chapter concerns prophecies drawn from the following parts of the Bible: Chapter 2: Mosaic prophecies; Chapter 3 and 4: Psalms; Chapter 5: Isaiah and Song of Solomon; Chapter 6: Isaiah; Chapter 7: the remainder of the Old Testament prophets; Chapter 8: New Testament conversionary examples.

${ }^{59}$ John Oxenbridge, "Conversion of the Gentiles, ca. 1670," Ms. Sbd-56, Massachusetts Historical Society, 11, 13.

${ }^{60}$ Ibid., 14.

${ }^{61}$ Ibid., 23-4.
} 
whether or not the apostles accomplished the totality of evangelization to the gentile populations during their lifetime: a necessary predicate for the next three chapters, which refute objections to indigenous missions. Oxenbridge drew on the genealogy of Jesus, recorded in Matthew 1:3-5, to highlight the inclusion of Rahab and Ruth within Christ's lineage. If this genealogy grafted gentiles into the literal family of Jesus, then this offered a powerful biblical imperative for reintegrating them in Oxenbridge's day. He surmised that "heathens" might learn this and know that "they have an interest in him as coming from and for them." Furthermore, the adoration of the magi (gentiles), Christ's retreat as a child to sanctuary in Egypt (a gentile nation), and the fact that the unconverted served as the principal audience for his first sermon in Matthew 4 clearly established the intimate connection between puritans and their indigenous neighbors. ${ }^{62}$ Within the ninth chapter, Oxenbridge developed an eschatology surmising that the gentiles remained unreached in the present, as the culmination of evangelization necessarily preceded the “scales falling from Israel's eyes," which remained unrealized. ${ }^{63}$ Thus, Oxenbridge's theology remained optimistic in regard to the potential and nature of indigenous conversions and religious communities, cogently delineating a place for indigenous conversionary experiences.

After this lengthy defense for the biblical support of indigenous conversion, Oxenbridge turned his attention to "exceptions against Indian conversions," the first of which was the argument that the Apostles had already reached all of the gentiles God intended to convert. To this, Oxenbridge chastised his readers for doubting the extent of God's love and placing indigenous populations on the same level of beasts. Such a view was unnatural and abhorrent, for “the same blood run's in ye veins of an Indian as in thine. Whatsoever thou makest of them God

\footnotetext{
${ }^{62}$ Ibid., 48.
}

${ }^{63}$ Ibid., 70 . 
hath made of one blood all nations of men." ${ }^{\prime 64}$ Oxenbridge urged his readers to remember that Paul rebuked Peter for rejecting gentiles as unclean in his letter to the Galatians, so they must avoid doing the same to Indians, or else they were no better than the Spanish in their treatment of Indians as "dogs." In countering charges of barbarity, Oxenbridge noted that the Romans were both cruel and barbaric, yet they benefitted from the Gospel's expansion, as did other regions within Europe throughout history. In an exploration of "whether ye Indians are more vicious than those nations wich have ye name of Christianity and ye gospel," Oxenbridge marshalled numerous quotations which praised Indians for their civil quality and cited his own firsthand encounters to assure his readers that many charges of barbarism were exaggerated. Thus, Indians naturally required time to reach a level of civility conducive to the Gospel's conversionary power. In the next chapter, Oxenbridge concerned himself with refuting the argument that it was futile to minister to Indians if they were actually Jewish in origin, and thus not part of the gentiles expected to convert before the mass Jewish reconversion. By this reasoning, missions were a wasted effort when they would instantaneously reconvert in anticipation of the millennium. To this, Oxenbridge offered a systematic rebuttal of Thorowgood's tract on the Jewish origins of Indians to further his portrayal of Indians as gentiles. ${ }^{65}$

The remaining chapters offer an interpretation of ecclesiastical history to place English history and indigenous conversions within the long span of Christian conversions, for "Indians must have their proper season also." Oxenbridge reminded his readers that the English converted after the time of the Apostles, which served as weighty evidence in support of indigenous conversions at this time, and proceeded to highlight notable conversionary moments century-bycentury in an ongoing advancement. Oxenbridge concluded that indigenous conversions would

\footnotetext{
${ }^{64}$ Ibid., 70-71.

${ }^{65}$ Ibid., 72-74, 80. Oxenbridge contended that those who planted among them and charged Indians with barbarity were often more deficient in morals than their Indian neighbors.
} 
naturally occur before the great Jewish reconversion and were necessary for this moment in biblical eschatology to occur. ${ }^{66}$ In the long span of ecclesiastical history, God's providential timing led to the conversion of many different people, whose initial "barbarism" made them equally unlikely candidates for Christian conversion, especially when compared to North American Indians. To Oxenbridge, the continual advancement of evangelization and conversion ensured that Indian contact with the gospel occurred in anticipation of millennial predictions and would ultimately prevail, despite objections from colonists and Englishmen who doubted God's provenance and the efficacy of their conversion. Oxenbridge insisted that Indians would convert, but that they required "some knowledge and [taste] of God and his ways before else they would not desire and inquire after more of him." ${ }^{\prime 67}$ Thus, missionary activity should proceed and equip Indians with the knowledge necessary for conversion, regardless of their origins as gentiles or Jews.

Though it is difficult to assess the full ideological impact of the treatise, as it remained unpublished, Oxenbridge's consistent reliance on biblical prophecy and use of ecclesiastical history to highlight the westward movement of the Gospel served to situate contemporary indigenous missions within the history of Christianity. Similarly, comparisons to England's own history as a gentile nation converted by missionaries served as a powerful invective against arguments that the conversion of Indians was a hopeless venture. By drawing on examples which highlighted both God's providence in spreading Christianity to various gentiles and the breadth of time required to accomplish such a great task, Oxenbridge asked potential readers to draw on their own understanding of England's uncivilized past and to show compassion for people whom he believed still faced a long journey before they became adequately "civilized." To Oxenbridge,

${ }^{66}$ Ibid., 78, 86, 104-105.

${ }^{67}$ Ibid., 108. 
missions required both time and perseverance, two commodities found in increasingly short supply with the anxieties in the 1660s and 1670s regarding the spirituality of the rising puritan generation and relations with unconverted Indian neighbors.

\section{Covenant Anxieties in the Wake of the Restoration}

In addition to the place of Indians within the colony as a whole, puritans had much to be anxious about in the years following the Restoration, as the Crown sought to impose tighter restrictions and oversight to the puritan commonwealth. ${ }^{68}$ If the apocalyptic predilections of Eliot and his ilk were chastened in the wake of the Restoration, as the poor timing for the publication of Eliot's The Christian Commonwealth in 1659 necessitated a hasty retraction because of its antimonarchical sentiments, this did not completely disparage missionaries from continuing their activities to convert those whom they viewed as wayward gentiles or Jews. ${ }^{69}$ Within his "Conversion of the Gentiles," Oxenbridge argued that the historic migration of the true church had been East-West, and that perhaps this pattern continued with the establishment of indigenous churches in New England in the wake of the Restoration. ${ }^{70}$ At the same time, the wider colony

\footnotetext{
${ }^{68}$ For more on the Crown's response in the Restoration and colonial responses, see Carla G. Pestana, The English Atlantic in an Age of Revolution, 1640-1661 (Cambridge: Harvard University Press, 2004), 155-156, 213-226. William J. Scheick highlights the importance of John Davenport's text The saints anchor-hold in all storms and tempests preached in sundry sermons, and published for the support and comfort of Gods people, in all times of trial (1661) as another effort to interpret biblical eschatology in light of the failed Puritan revolution in England, suggesting that Davenport initial considered this failure as befitting, though he became more apprehensive later, especially with the expansion of the Half-Way Covenant and the Restoration's emphasis on crown-mandated religious toleration. William J. Scheick, "An Inward Power and Authority: John Davenport's Seditions Piety," Religion \& Literature 33 (2001): 1-4, 18-19.

${ }^{69}$ Contrary to the analyses of Christopher Hill, Warren Johnston asserts that apocalyptic thought continued unabated in the wake of the Restoration, and that it was complementary to mainstream Anglican thought as well. Indeed, the propensity of Anglican ministers to link Restoration with biblical eschatology suggests the ubiquity of this tendency to interpret contemporary events in this vein. Warren Johnston, "The Anglican Apocalypse in Restoration England, The Journal of Ecclesiastical History 55 (2004): 475, 500. In the second chapter of her monograph, Kathryn N. Gray highlights the shift in tone of Eliot's tracts after 1653 and efforts to generate a rapport with an English readership that was decidedly more hostile towards New England after the Restoration. Gray, John Eliot and the Praying Indians, 29-38.

${ }^{70}$ Oxenbridge, "Conversion of the Gentiles," 15.
} 
faced the challenge of generational differences between the initial settlers and their children born in New England, who came of age during this time. It is no surprise then, that the sermonic literature around the time of the Half-Way Covenant shifted to embrace a far more ominous and pessimistic tone when addressing the youth of the colony. By and large, the sermons following the Covenant's development show a heightened sense of fixation on internalized piety, the importance of physical space in metaphors of a wilderness sojourn, and concern for the future of the colony.$^{71}$ In an Election Day sermon titled The Cause of God and His People in NewEngland (1663), John Higginson, pastor of the Salem church, stressed the need for reform amidst the impiety found within the colony which took them out from under God's protection. Higginson suggested that the gravity of this task necessitated the participation of the colonists alongside God through the implementation of the Half-Way Covenant: "That Baptisme be administred to the Children of Church Members who have right thereunto. And that the Communion of Churches be better improved amongst us, These are things we have been defective in, and therefore should be reformed in a practicall way." ${ }^{72}$ Similarly, in a sermon titled A Quickening Word for the Hastening a Sluggish Soul to a seasonable Answer to The Divine Call (1670), John Oxenbridge cited delay in owning the covenant as the principal cause of sin and suffering, yet this foolish disposition could be quickly cut short by death. Oxenbridge

\footnotetext{
${ }^{71}$ Thomas Walley's Balm in Gilead to Heal Sions Wounds (1669) serves as a representative example of the New England jeremiad. Within this sermon, Walley chastised the colony for its failure to live up to the expectations of the founding generation by turning to profiteering and mercantile interests. Utilizing the text of Jeremiah 8 as his expository foundation, Walley used the example of Israel's failure to keep their covenant with God despite the blessings at his disposal. In the end, hidden sin, old and deeply-rooted sin, and the foolhardy belief that there was no inner sickness plagued the Israelites and the colonists. Walley pointed to the low number of children owning the covenant once they reached adulthood as principal evidence for the presence of inner sin, along with the divisions between communities. Thomas Walley, Balm in Gilead to Heal Sions Wounds (Cambridge, 1669), 3, 6-7, 11, 15-16. In a similar sermon, Samuel Danforth, pastor at Roxbury, highlighted the parallel to John the Baptist's wilderness retreat, but chastised his parishioners by stating that "the ground and principal cause [for the colony's failures] is our Unbelief." Samuel Danforth, A Brief Recognition of New-Englands Errand Into The Wilderness (Cambridge, 1671), 1-2, 14. See also: John Higginson, The Cause of God and His Pe4ople in New-England (Cambridge, 1663), 11-12.

${ }^{72}$ Ibid., 14. Higginson's mention of the "communion of churches" is in reference to the provisions in the 1662 Covenant that the churches of New England function in a way that more closely resembled the Presbyterian model of synods, a point highly contested in the sermonic literature which followed its adoption.
} 
exhorted his Boston congregation to "buy that precious Pearl [belief] by the Inch of Candle, while Life and Season lasts... you have no ground of delay; for this life, and what depends upon it, is uncertain; nothing of this life is certain, but the going out of it." ${ }^{, 73}$ Puritan ministers like Oxenbridge and Higginson focused increasingly on the inward state of sin and disbelief believed to be rampant throughout the colony, but ministers also turned to reading outward signs in the world to evaluate the state of their covenant with God.

Maintaining the covenant forged by the founding generation of puritans was of particular importance to the colony's ministers because the Old Testament offered ready examples of the consequences of reneging on this agreement between men and God. In a 1671 sermon entitled $A$ Serious Exhortation to the Present and Succeeding Generation in New-England, Eleazar Mather stressed the special providence and attention God gave to those in covenant with him: "His eyes are open upon his Temple, and upon his Church continually, preserving and providing for them, and protecting of them, and comforting of them." ${ }^{.74}$ Mather continued his sermon by delineating signs by which puritans could determine the absence of God's presence and his abandonment when people failed to uphold the covenant. This included "a slight spirit, not minding the Lord's Presence," as well as the loss of "the chief Instruments and Means of his Presence, and gracious Blessing to a People." Mather also cited the growth of "temporal blessings" accompanied by "the abounding of sin," and "a Spirit of Division and Contention in matters of Gods Worship." Finally, Mather warned that the loss of God's blessing made puritan worship and ministration ineffectual: "they are the words and breath of men onely, without life to their Souls." ${ }^{75}$ In one of

\footnotetext{
${ }^{73}$ John Oxenbridge, A Quickening Word For The hastening a Sluggish Soul to a seasonable Answer to The Divine Call (Cambridge, 1670), 7.

${ }^{74}$ Eleazar Mather, A Serious Exhortation to the Present and Succeeding Generation in New-England (Cambridge, 1671), 2-3. Scriptural references have been omitted from this quote to improve its readability. Mather Cited 2 Chronicles 16:9, Genesis 28:20 and 48:15-16, Hebrews 13:5, 10 and Isaiah 43:2 and 41:17 as the scriptural basis for the quotation above.

${ }^{75}$ Ibid., 7-11.
} 
his final sermons published posthumously, John Allin warned that "God is an Enemy against sin, and sinners and they are at enmity with God ... the Holy Just God [is] an enemy to him, that will avenge himself on his enemies by Eternal punishment." To avoid such a fate, Allin urged repentance and holding fast to the covenant forged in New England. ${ }^{76}$ These puritan ministers surprisingly evaluated their situation in ways similar to the exhortations of the indigenous ministers recorded in various Eliot Tracts, proposing similar remedies through reform.

An emphasis on God's punishment for inward sin, meted out after clear signs that his favor had departed from a people for breaking their solemn covenant is particularly relevant to understanding how puritan ministers and congregations evaluated their spiritual kin in Praying Towns. As a covenanted body, puritans expected the Praying Indians to live up to the same spiritual rigor and to display similar good character through their continuing adoption of English mores and practices. When calamity beset these communities, especially in the heightened tension of the years leading up to King Philip's War, puritans could read the events which transpired as evidence of God's displeasure with themselves and the Praying Indians. In a sermon from 1673 John Oxenbridge berated his audience for their hypocrisy and warned that God would soon judge them and would "ignite the approach of a swift and ravenous enemy" against them because "they have broke the substance of their Covenant with God in the main Articles of it." ${ }^{77}$ Oxenbridge warned that the colonists would be forced to choose between God and mammon, and that the colony's inner factionalism mirrored the division between Abraham and Lot in Genesis 13:7, which was foolish in light of the danger the Canaanites represented. Oxenbridge viewed this ministerial factionalism as similarly detrimental in light of the danger Philip and the Wampanoag represented, so he urged the colony's ministers to put aside their

\footnotetext{
${ }^{76}$ John Allin, The Spouse of Christ Coming out of affliction, leaning upon Her Beloved (Cambridge, 1672), 14.

${ }^{77}$ John Oxenbridge, New-England Freemen Warned and Warmed, To be Free indeed, having an Eye to God in their Elections (Cambridge, 1673), 2.
} 
differences in order to strengthen church relations and for the conversion of the colony's youth in an effort to avert God's wrath. ${ }^{78}$

Tense relations with Native Americans shaped the sermon Increase Mather delivered in December 1673. Relying on Ezekiel 7:7, he drew an explicit parallel to the colony's plight against Philip and the punishment of Israel by the "Caldeans," who were "said to be the worst of men, yea the worst of the Heathen."79 Mather warned his audience that a covenant alone did not protect God's people and that on occasion "God doth sometimes bring Times of great Trouble upon his own People." Mather likened contemporary troubles to the biblical precedent of Israel's desert wandering before entering God's promised land, which puritans must similarly pass through "e're we can arrive at the heavenly Canaan." Drawing on Psalm 89:32, he reminded his audience that "sanctified afflictions shall be their portion, if need be," despite the promised protection inherent in the covenant. ${ }^{80}$ Mather charged that the troubles the colony faced stemmed from causes "within and without," as internal sin and corruption angered God and the colony faced the machinations of Satan, who sought "to raise storms of affliction." Mather warned that war loomed on the horizon as "the greatest of all outward Judgements," which would shake the colonists out of the complacency that came with their permanent establishment in New England and teach them to "know more of God." " Throughout the rest of the sermon Mather relied on standard apocalyptic imagery to describe the great trials the colony faced and the likelihood that militant Indians would besiege them, yet he also cast a note of hope by arguing that New England had a place within divine eschatology as the site of the "New Jerusalem." 82 He urged

\footnotetext{
${ }^{78}$ Ibid., 8, 42-44.

${ }^{79}$ Increase Mather, The Day of Trouble is Near. Two Sermons Wherein is shewed, What are the Signs of a Day of Trouble being near. And particularly, What reason there is for New-England to expect A Day of Trouble. Also what is to be done, that we may escape these things which shall come to pass. (Cambridge, 1674), 1.

${ }^{80}$ Ibid., 3-4.

${ }^{81}$ Ibid., 5-6, 8, 15.

${ }^{82}$ Ibid., 19-21, 26-27.
} 
the colony to prepare for punishment and embrace moral reform, praying that God would spare them during this day of trouble. Within Mather's formulation, Indians could occupy a divine role whereby God would chasten and punish the colony for its sins, but in the end God's providence would still reign because their gentile tormentors remained unsaved and unconverted, subjecting them to God's wrath. Neglecting to make explicit mention of Praying Indians in the context of the colony's sins and looming punishment, they occupied a tenuous ecclesiastical space in the minds of Mather and Oxenbridge. As young converts on the way to gradual sainthood, their status as a covenanted body meant that they were similarly responsible for the impending wrath, while at the same time, the tendency to doubt the sincerity of native conversion also meant that they might fall in against the colony and prove to be part of God's punishment.

\section{Praying Indian Communities before King Philip's War}

In addition to navigating the theological debates that wracked New England throughout the 1660s, Praying Indians also faced the realities of living in close proximity to their English neighbors and establishing a new and hybridized Praying Town culture amidst the expectations and impositions of colonial officials, English missionaries, and traditionalist Indian communities. As tensions began to rise throughout the early 1670s between English authorities and Wampanoags under Metacom and his allied sachems, an increasingly militant and hostile puritan population subjected Praying Indians to more intensive scrutiny. This forced Praying Indians and their missionary allies to mediate the rising tensions of the decade and to protect their communities in the face of pressures to abandon the Praying Towns and side with traditionalists, which included expanding and strengthening the indigenous church as a foundation of Praying Town culture. Similarly, it is instructive to examine the religious claims proposed by Indians and 
missionaries as a defense of the legitimacy of the newly constructed Praying Indian identity as a means of establishing their loyalty to the colony amidst charges of disloyalty and accusations of betrayal. Relying on the efficacy of gradual conversion and the federal covenant of visible saints, Indians and their supporters relied on explicitly religious claims to placate their opponents, though these claims proved insufficient to overcome the hysteria generated by open warfare in 1675.

A ten year gap exists between Eliot's 1660 tract and the 1670 tract entitled A Brief Narrative of the Progress of the Gospel amongst the Indians in New-England, in the Year 1670, but during this brief span, the Praying Indian communities took on a life of their own and expanded far beyond Eliot's initial expectations. In anticipation of owning the ecclesiastical covenant themselves, Mashpee gathered a church with the help of relatives and kin from the Natick community and organized an examination before colonial magistrates and ministers. Tellingly, the magistrates approved of the examinants, appointing Richard Bourne as the English pastor and "Jude" as the Indian ruling-elder, and those who owned the covenant also had their children baptized in a clear implementation of the Half-Way covenant, as did the church gathered at Martha's Vineyard. ${ }^{83}$ The communities at Natick and Martha's Vineyard, by now longstanding sites of cross-cultural exchange between Indians and missionaries, both moved to forge new connections with a growing collection of satellite Praying Towns. A group of Nantucket Indians expressed a desire to form a similar community, and the English suggested that members of the Martha's Vineyard community join them in forming a new church. Similarly, Natick churchmembers supported the young town called Magunkukquok, settled at their western border, and the town of Hassunnimesut enjoyed the assistance of Monatunkanet as a second teacher and supervisor of plans to found yet another Praying Town near

${ }^{83}$ Clark, ed., The Eliot Tracts, 400-01. 
Hassunnimesut's neighbors at Quanatusset. Eliot estimated that Natick held between forty and fifty full communicants within the gathered church by 1670 , which was supported by indigenous ministers John Speene and Anthony in keeping with Eliot's growing recognition of the need for native autonomy and their superiority as ministers. ${ }^{84}$ In 1671, Eliot informed the New England commissioners that a group of forty Natick church members intended to establish a new church and community among the Nipmuc, which again serves to emphasize the centrality of church membership and the growing interconnections between Praying Towns as a result. ${ }^{85}$

The communities also faced setbacks and challenges during these years of initial efflorescence, which consisted of a combination of internal division and external conflicts with their English neighbors and hostile Indians. Within Punkapoag, the indigenous church faced the loss of its minister William, who they replaced with another man named William, the son of Punkapoag's chief ruler and blood sachem Ahauton. Blood kin similarly ruled the town of Hassunnimesut, as Anuweekin served as chief ruler and his brother Tuppukkoowillin served as chief teacher, a pattern in keeping with traditional lineages and indigenous political and religious leadership. ${ }^{86}$ In the town of Okommakamesit, where the English had settled the town of Marlborough within the sachemship of Onomog, Eliot noted that the community censured one teacher for drunkenness, but the English and Indian towns had managed to coexist peacefully

\footnotetext{
${ }^{84}$ Ibid., 401, 403, 405-06. In a private letter to Robert Boyle, also from 1670, Eliot reinforced his insistence on beginning "a kind of academical reading unto them, in their own language, thereby to teach the teachers and rulers, and all that are desirous of learning," which he also hoped to expand to include medicine in an effort to combat the illnesses that best the communities. Letter, "John Eliot to Robert Boyle, 30 September 1670," in ," in Collections of the Massachusetts Historical Society 1:3, 177-78. The number of communicants had grown to between forty and fifty from thirty to forty in 1669 , according to a letter from Eliot to Boyle dated that year. According to Eliot, in 1669 there were many others "upon ye pbatory confession to be received," with one more member under censorship. Apparently, some of those under probation were counted as full members the following year. Ford, ed., Some Correspondence Between the Governors and Treasurers, 27.

${ }^{85}$ Ibid., 45.

${ }^{86}$ Clark, ed., The Eliot Tracts, 403.
} 
despite the fact that the English church was within indigenous territory. ${ }^{87}$ Perhaps the most divided town was Wamesut, where a group of traditionalists who continued to live with their Praying Indian brethren convinced Indian Christians to join them in an abortive raid against the Mohawks who had been attacking the community with growing intensity in the preceding years. Frequent attacks forced Daniel Gookin to organize a garrison to protect the Praying Indians there, yet Eliot saw God's punishment in the community's destruction because the traditionalist sachems refused to convert. Eliot optimistically noted that the destruction of the community had brought many of its survivors firmly into the arms of their fellow Praying Indians. ${ }^{88}$

John Cotton, Jr. entered the mission project in 1666 when he delivered his first sermon on March 6 to the Wampanoag gathered at Chappaquiddick. As with Eliot's initial sermons, Cotton was greeted with a number of questions from the crowd on the following topics: salvation and damnation, the nature of Christ's baptism (whether he was immersed or sprinkled), and the nature of consciousness. When he delivered a second sermon, the indigenous minister John Toquenosh confronted Cotton and claimed that he had contradicted an earlier sermon delivered by Mayhew, which led some of the Chappaquiddick Wampanoag to assume that Cotton and Thomas Mayhew were at odds. In his discussions with Toquenosh, Cotton learned that Mayhew had told Toquenosh and Joshua that he refused to preach to the Praying Indians again unless they stopped attending Cotton's sermons, and that Cotton had told Mayhew that the Indians stink. ${ }^{89}$ Despite this apparent spat between Cotton and Mayhew, Cotton continued to preach to the community at Chappaquiddick, answering questions about whether it was "right to leave the

\footnotetext{
${ }^{87}$ Ibid., 404. "A Description of Marlborough, in the County of Middlesex. By Rev. Asa Packard," in Collections of the Massachusetts Historical Society 1:4, 46.

${ }^{88}$ Clark, ed., The Eliot Tracts, 405. Eliot had previously urged the colonial leaders of the New England Company to press Boyle and the English branch of the Company for ammunition so that the Praying Indians could protect themselves against the Mohawks in 1668. In a personal letter to Boyle, Eliot commented further on the divide between the Praying Indians and those who continued powwowing. Ford, ed., Some Correspondence Between the Governors and Treasurers, 20, 30.

${ }^{89}$ Diary, John Cotton, Jr. Ms. N-1042, MHS, 8-9.
} 
minister in their own town to go hear another in another town," why children should be baptized, "Whether our fathers that died before they heard of God or knew him are saved or not," and, tellingly, "whether it be a righteous thing for Mr. Mayhew to buy away so much of the Indians land?" ${ }^{90}$ Cotton continued to minister to the community and expanded his preaching to Indians near his Plymouth home in 1670, quickly organizing a body of thirty Praying Indians as handfuls of listeners expressed a desire to follow this new faith with each sermon that he delivered. ${ }^{91}$

In the transatlantic discourse between Eliot, Mayhew, the New England commissioners for the Company, and members of the English branch, theological preparation continued to be the primary strategy for expanding the missions, however slowly this unfolded. Though virtually everyone involved with the project complained of the lack of funding and the small number of ministers dedicated to this labor, Eliot optimistically wrote to Henry Ashurst, treasurer of the Company, that despite their distresses "it is a liberal \& gloryous seed time, the word of grace mixed with the crosse, will be exceeding fruitfull unto conversion... to bring forth the greater harvest of saints \& believers." ${ }^{92}$ Frugality pushed the English directors to halt the publication of Indian language works in 1669, yet Eliot and Richard Bourne convinced the New England branch to authorize a local publication of an Algonquian primer and small catechism because "the instruction of the Indians [was] greatly obstructed" without the texts, which the New England commissioners hoped their English brethren approved. Thus, Eliot continued to promote

\footnotetext{
${ }^{90}$ Ibid., 9-13.

${ }^{91}$ Ibid., 27-31. In his diary, Cotton often wrote brief descriptions of the sermon text that he utilized as well as the names of particular people who expressed a desire to become Praying Indians. On rare occasions he offers more details, such as the fact that one Indian, whom he renamed "Naomi," was the daughter of Tuckpoo, a sachem who adamantly opposed "praying to God." Cotton considered it worthwhile to commend Naomi's decision in light of her father's influence, as she would "obey God rather than man, and did promise to serve God" despite her father's admonitions. Again, this exchange highlights the tension provoked by these religious decisions, described in greater detail within chapter two. Ford, ed., Some Correspondence Between the Governors and Treasurers, 47-48.

${ }^{92}$ Ford, ed., Some Correspondence Between the Governors and Treasurers, 38.
} 
indigenous piety that relied on Algonquian literacy. ${ }^{93}$ In a letter to Ashurst dated October 1671, Eliot gave the treasurer a mixed update on the project, as "our meeting for Prophesy, \& for [our] logik readings, doth goe on with a blessing, but our means is spent, by the history of this yeare, you will see what charges \& expences I was put unto." ${ }^{.94}$ Despite financial difficulties, Eliot continued to approve and promote the progress of Praying Indians in matters of religious piety and education, which raises important questions regarding the nature of Praying Indian religiosity in the years before King Philip's War.

If these communities clearly grew at a rapid pace during this period, with covenanted Indian church members serving as the principal agents for expansion, then it is worthwhile to explore the nature and makeup of these indigenous churches. In an August 1673 letter, Eliot answered an inquiry from Thomas Shepard, Jr. regarding the nature of the six organized churches within the colony, arguing that the services they conducted closely approximated the English style. Eliot was unable to provide figures regarding the total number of covenant members spanning the network of churches, but he stated that all baptized members, along with their children (again implementing the Half Way Covenant), were registered at Natick. Additionally, indigenous ministers delivered the sacraments to their members and church officers administered ecclesiastical governance in all of the churches except for Natick, where the congregation insisted that there was no need for officers. ${ }^{95}$ Eliot insisted that the Indian churches also "have communion in the Sacraments \& send messengers to gatherings of churches," but without the benefit of formal synods. In matters of instruction and discipline, Eliot noted that literacy progressed slowly, although "all learne \& rehearce catechise," and that their order of church discipline mirrored English practices, which slowly added to the number of visible saints

\footnotetext{
${ }^{93}$ Ibid., 32-33.

${ }^{94}$ Ibid., 50.

${ }^{95}$ Letter, "John Eliot to Thomas Shepard of Charlestown, 22 August 1673," Box-L 1952, MHS, 1-2.
} 
among them. In a similar letter to the New England commissioners, Thomas Mayhew concurred that the Nantucket and Martha's Vineyard churches "uphold the publique worshipp and service of God" in accordance with orthodoxy, and that he met weekly with the two pastors and one of the elders to discuss religious instruction and the expansion of the missions. ${ }^{96}$

By all appearances and accounts, both Eliot and Mayhew recognized the indigenous churches as equal in their autonomy and conduct after attaining a status of parity and recognition from the English churches and ministers of the colony. In his letter to Shepard, Eliot described the process of owning the covenant within Natick as follows:

they are diligently instructed \& examined, both publikly \& privatly in the Catechise. theire blameless \& pious conversation, is publikly testified. theire names are publikly proposed, as desiring to make confession \& joyne unto the church. the Teachers \& cheife brethren do first heare theire preparatory confessions, \& when they judg them meet, they are called publikly to confesse, confederat, \& be baptized, both themselves \& theire children, if not upgrowen. the upgrowen are called upon to make theire owne confession, \& so to be baptized, as their parents were.

While attempting to stress conformity with English practices, Eliot emphasized that the visible church at Natick held an equal responsibility in preparing, examining, and accepting new members within the covenant. He also reiterated the implementation of the Half Way Covenant within Natick as well. He further noted that he had encouraged the English church at Martha's Vineyard to accept the Praying Indians into a mixed service when he visited and administered the sacraments as a necessary step towards further integrating Indians "whom the Lord hath so manifestly undenyably accepted" as visible saints. ${ }^{97}$ In both his letter to Shepard and a 1671

\footnotetext{
${ }^{96}$ Ibid., 1-2. Ford, ed., Some Correspondence Between the Governors and Treasurers, 39-40. In this letter, Mayhew also estimated that there were three other religious gatherings in addition to the two at organized churches with approved covenants. At Elizabeth Island, for instance, there were seven Praying families out of the fifteen living there who met regularly in their own informal gathering (41).

${ }^{97}$ Letter, "Eliot to Shepard," MHS, 2. In a 1670 letter to Boyle, Eliot also stressed that he had written to various ministers in the colony to try to encourage them to accept Indians from neighboring Praying Towns for instruction. Ford, ed., Some Correspondence Between the Governors and Treasurers, 36. Interestingly enough, in this account of the Natick church, along with the 1670 account, Eliot and the other missionaries stress the application of the Half-
} 
letter addressed to the colonial commissioners, Eliot stressed that the maturation of Praying Indian children had produced capable young ministers who were now able to teach on their own. Eliot thus expanded his instruction to include supervised exercises in prophecy, for "theire pfiting thereby, is very evident to all. It puteth life into them." 98 In stressing the piety of the visible churches organized within the growing network of Praying Towns, Eliot and Mayhew similarly defended the Praying Indians despite the growing hostility within the colony on the eve of King Philip's War.

As colonists throughout New England grew increasingly hostile to Indians, missionaries and Englishmen involved in the expansion of Praying Towns found themselves under increased suspicion from the wider colony. Praying Indians faced similar scrutiny and sought to ameliorate these charges by serving as mediators and informants, while stressing their loyalty and commitment to their shared religious lineage. In a letter drafted by Eliot with the consent of the Natick church in August 1671, the community sent William and Anthony as delegates to Philip, along with John Sassamon, because they had previously served as messengers to that community and Eliot believed that they could mediate a peace between the Wampanoag and the English. Eliot hoped that the Natick community might take the lead in brokering a peace as a first step in the conversion of the Wampanoag, so he and the Natick church sent the men with scripture

\footnotetext{
Way Covenant within these religious bodies, years before the Covenant gained wider acceptance within the English churches of the colony. Katharine Gerbner places widespread acceptance of the Covenant around 1677 after King Philip's War. Gerbner, "Beyond the Halfway Covenant," 289.

${ }^{98}$ Letter, "Eliot to Shepard," MHS, 5. Ford, ed. Some Correspondence Between the Governors and Treasurers, 44. This passing reference to prophecy holds interesting implications, along with difficulties in determining exactly what Eliot meant. Prophecy and visions obviously held an important place within indigenous cosmologies and religious practices, so this could have been a way for Praying Indians to continue this tradition within the religious framework that they adopted. Similarly, prophecy and mysticism clearly coincided with Eliot's own millenarian worldview, so he likely promoted native prophecy within a purely Christian framework, despite the fact that Indians imbued this ritual with their own significance. Regardless, Eliot's approval of this practice and public mention of it (given the circuitous and open nature of epistolary correspondence during this period) serves to highlight the degree to which he accepted indigenous piety as authentic, and Praying Indians as capable of conducting such a controversial act. The fact that this enlivened Praying Indians also lends credence to the importance of hybridized religiosity within Praying Towns and the notion that this was a practice they revered, for whatever the reason.
} 
passages to exhort Philip and a message to the governor of Massachusetts expressing their desire to arbitrate in this dispute. ${ }^{99}$ In addition to arbitration, Praying Indians also stressed their amity towards the Massachusetts government as well as a willingness to fight in any impending conflict, as Thomas Mayhew reported to the New England commissioners in 1671. Mayhew reported that the sachems had gathered with him and acknowledged our king to be theirs \& to fight for him and with his subjects against his \& theire enemies... expecting from them no other Returne but that they lyved quiettly \& peaceably under the govment he had sett over them." In a postscript to this letter, Mayhew noted the he had discerned no plot transpiring among the Indians at Martha's Vineyard, though "tis hard to find amongst the English a moderate Interpretation of the word \& actions of the Indians I speake to such as pass by \& comes in here ass well as of ourselves." In evaluating his own relationship with the community, Mayhew stressed that he often dealt with them more harshly and critically than his fellow colonists realized, "though it has been usually aprehended to the Contrary," and that he worked "to prevent suspition" from the magistrates and the rest of the colony. ${ }^{100}$

The role of superintendent and magistrate overseeing the Indian courts which governed the Praying Towns placed Daniel Gookin in a particularly vulnerable position as Praying Indians came under colonial suspicions. In April 1671, Gookin wrote an impassioned note to Governor

\footnotetext{
${ }^{99}$ Letter, "Instructions from the Church at Natick to William and Anthony, 1 August 1671," in Collections of the Massachusetts Historical Society 1:6, 201-203. The texts Eliot sent were Deut. 20:10-11 and 1 Cor. 6: 1-6, the first of which exhorted the Israelites to offer a city peace before conquest. In the event of a peaceful arrangement, the cities they approached were to serve them as tributaries, which Eliot expected Philip to do in asking him to subject himself to Massachusetts governance. The second text stressed the correctness of church governance and the superiority of Christian judgment over that of "infidels." Here, Eliot likely drew inspiration from the commentary in the Geneva bible, which stressed that infidels cannot judge visible saints, and intended Philip to recognize the authority of the Christian scriptures and subject himself to Massachusetts judgment. It is unfortunate that no direct response from Philip exists to gauge his reaction to this diplomatic message.

${ }^{100}$ Ford, ed., Some Correspondence Between the Governors and Treasurers, 40, 42-43. Mayhew reiterated this message almost verbatim to Governor Prince in another letter, stressing that the Praying Indians of the community implored him to write to the governor on their behalf and that they remained within their homes "lest they bring trouble on themselves" by interacting with the English. Letter, "Thomas Mayhew to Governor Prince, 19 August 1671," in Collections of the Massachusetts Historical Society 1:6, 196-97.
} 
Prince denouncing an anonymous colonist of high standing who had told Prince that Gookin spoke ill of his leadership to a Natick Indian, which further incited Philip against the Massachusetts governor. Fearing the political damage that his silence might cause to himself and the governor, Gookin wrote: "my innocency is to me a sufficient shield in that respect; but if I should be altogether silent, it might be interpreted that I am guilty." ${ }^{101}$ Prince responded to reassure Gookin that he harbored no ill will toward him and that he merely intended to investigate the substance of the claims, noting that his accuser wrote that Gookin said it was "not [worth] fighting with Indians about horses and hog, as matters too low to shed blood." Prince agreed with the sentiment and thanked Gookin for taking the initiative to clear up any misunderstanding, for "any scruples or jealousies on our part needlessly to interrupt the peace of the country, is, by that prudent act of yours, removed." Prince recognized the efforts Gookin had undertaken to strengthen the defenses of the colony, presumably through his work with the Praying Indians, and thanked him for sending messengers to inquire about the status of colonial defenses and any aid they could provide as "a high experiment of Christian prudence."102 Despite efforts to defend themselves and the Praying Indians against growing unpopular sentiment, Gookin, Mayhew, and Eliot appealed to their continued loyalty and the loyalty of the Praying Indians. By attempting to insert Praying Indians into the conflict as Christian ambassadors, Eliot relied on their status as indigenous Christians to facilitate peace. In doing so, he attempted to highlight their necessary role to the magistrates of Massachusetts. Despite this tactic, the colony's governors eventually succumbed to popular pressure and confined the Praying Indians

\footnotetext{
${ }^{101}$ Letter, "Daniel Gookin to Governor Thomas Prince, 12 April 1671," in Collections of the Massachusetts Historical Society 1:6, 198-199.

${ }^{102}$ Letter, "Governor Thomas Prince to Daniel Gookin, 26 April 1671," in Collections of the Massachusetts Historical Society 1:6, 200-201.
} 
to progressively worsening conditions by the end of the war. ${ }^{103}$ Gookin himself would continue to write one of the strongest defenses of the Praying Indians and their religiosity with his Historical Collections of the Indians in New England (1674) and The Doings and Sufferings of the Christian Indians (1677).

\section{The Shadows of War}

For the Praying Indians who formed new communities at Natick, Punkapoag, Chappaquiddick, and Mashpee, to name a few, their early efforts to learn the rituals and theology of English puritanism drew them into closer contact with missionaries like John Eliot, Thomas Mayhew, and John Cotton, Jr., and placed them on a long and difficult path to visible sainthood. Puritan anxieties about Indian deficiencies in civility and theology dampened Eliot's fervency to establish both a civil and ecclesiastical polity at Natick during the 1650 s, which contributed to a growing emphasis on theological preparation, catechesis, and instruction. The efficacy of this mode of conversion finally allowed Praying Indians to achieve a measure of religious parity within the colony, as Indians administered sacraments within Indian-led churches that were vigorously expanding in the years preceding King Philip's War. The example of the Praying Indians also factored into debates surrounding the state of English religiosity and the Half-Way Covenant of 1662. By embracing a process of gradual sanctification and church membership,

\footnotetext{
${ }^{103}$ The treatment of the Praying Indians repulsed Gookin and led him to write two texts on their experiences during the war. Contrary to traditional portrayals of Indians in colonial literature, Gookin highlighted their sufferings as evidence of their persecution as visible saints amidst colonial impiety. For more on Gookin's transatlantic connections and the various ideas he defended and ways in which he promoted the Praying Indians during King Philip's War, see Louise A. Breen, "Praying with the enemy: Daniel Gookin, King Philip's War, and the dangers of intercultural mediatorship," in Daunton and Halpern, eds., Empire and Others, 101-122. This chapter is in part an attempt to address Breen's observation that no study explicitly examines the Indian connections to the Half-Way Covenant, and that Gookin's high-profile status and promotion of the Half-Way Covenant contributed to resistance against this sacral innovation (106). The next chapter will explore the ecclesiastical connections between Praying Indians and Puritans in the colony during and after King Philip's War in a continued effort to analyze these religious connections and conflicts.
} 
puritan ministers who supported the Covenant unconsciously forged a theological innovation that was rooted in the lived history and example of the Praying Indians.

The anxiety created by this connection is most apparent in the later history of the colony as it lurched closer to open warfare in the early 1670s and ministers worried about their perceived failures and God's impending punitive wrath. While colonists could point to the rising generation of puritans and their failure to own the covenant, they could also turn a suspicious eye to their Praying Indian neighbors. As a visible church, linked to the wider ecclesiastical body of the colony, they shared responsibility for the colony's fate and shared the blame. At times, they instigated trouble with neighboring Indians and paid the price for this inability to overcome their traditional practices of warfare at towns like Wamesut. As penitents who still had much to overcome culturally in the process of becoming like the English, perhaps they shouldered even more of the blame for the colony's sins in the minds of New England's ministers. Despite efforts to prove both their loyalty to the colony and the sincerity of their faith, Praying Indian religiosity proved insufficient to shelter these communities from the wider general prejudice against Indians that intensified during King Philip's War and dislocated the colony’s Praying Towns. 


\section{Chapter Four \\ King Philip's War as Holy War: Theologies of Difference and Typological Barbarism, 1675-1700}

But such was the unhappiness of their affairs, or rather the displeasure of God in the case, that those counsels were rejected, and on the contrary a spirit of enmity and hatred conceived by many against those poor Christian Indians, as I apprehend without cause, so far as I could ever understand, which was, according to the operation of second causes, a very great occasion of many distressing calamities that befell both one and the other

\section{Daniel Gookin ${ }^{1}$}

The Lord hath performed all his work, his purging work, upon us, he can easily, and will lay by the rod... to exhort ym to humiliation \& repentanc to be patient is meete in the sight both of God \& men

\section{John Eliot ${ }^{2}$}

The Indian Christians of Nashobah tried to make the best of their fearful remove to Concord, where they lived with John Hoare and worked for him in and around the workhouse built to shelter them at night. Some sixty in number, the refugees had taken what belongings they could carry since the violence of King Philip's War had spiraled out of control and threatened to consume their community as well. ${ }^{3}$ In the tense climate of the war, they kept their heads down while working and tried their best to keep the peace with the Concord residents they now lived with. One Sunday morning while the Nashobah community gathered together for their weekly sermon and prayers, somebody heard the low din of a mob of angry voices, which grew louder as hundreds of people surrounded the house. There was a crack at the door, and a strange man

\footnotetext{
${ }^{1}$ Daniel Gookin, An Historical Account of the Doings and Sufferings of The Christian Indians in New England, in the Years 1675, 1676, 1677 Impartially Drawn by One Well Acquainted With That Affair, and Presented Unto the Right Honorable The Corporation Residing in London, Appointed By the King's Most Excellent Majesty for Promoting the Gospel Among the Indians in America, in Archoeologia Americana: Transactions and Collections of the American Antiquarian Society, Vol. II (Cambridge, 1836), 437.

${ }^{2}$ John W. Ford, ed. Some Correspondence Between the Governors and Treasures of the New England Company in London and the Commissioners of the United Colonies in America, the Missionaries of the Company and Others Between the Years 1657 and 1712 to Which Are Added the Journals of the Rev. Experience Mayhew in 1713 and 1714, (New York: Burt Franklin, 1970), 53.

${ }^{3}$ A Connecticut lawyer and supporter of the Praying Indians, Hoare later served as the principal English negotiator in the redemption of Mary Rowlandson along with the assistance of Praying Indians Tom Dublet and Peter Conway. Neal Salisbury, "Introduction," in The Sovereignty and Goodness of God by Mary Rowlandson with Related Documents, edited by Neal Salisbury (New York: Bedford/St. Martin's, 1997), 34, 43.
} 
demanded to see the Indians inside. John Hoare ran to the door and yelled through to the men on the other side. It was difficult for the Nashobahs to make out the exact exchange amidst the jeering of the crowd, but the men seemed to be arguing about their protection and who held the authority from the court. Finally, the English captain stormed off and left two men at the house, who insulted the Indians, calling them savages, barbarians, and heathens. As the crowd slowly dispersed, the Nashobah refugees clutched their loved ones and whispered to each other as they prepared for a long and sleepless night. ${ }^{4}$

There would be little rest for the Nashobah Indian Christians, for the ringleader of this crowd was none other than Captain Samuel Mosley: a man who sought to vent his profound anger towards all Indians who crossed his path during the tumult of King Philip's War. Mosely had already stirred up trouble in Boston where he took it upon himself to capture a group of Indians guarding a fort at Okonhomesitt, by neighboring Marlborough. He and his soldiers fell on the Indian Christians there and tied them up, looping interconnected nooses around their necks to lead their choking captives to Boston where a crowd called for their execution. When news of this reached Daniel Gookin, he went to the General Court to remind the magistrates that these were friendly Indians who were subject to English law, a point which convinced the magistrates to prevent their execution on that day and remove the Indians to safety. ${ }^{5}$ Despite this failed attempt at carrying out martial law, Mosely continued in this pattern of Indian-hating and lashing out against Indian Christians when he could, in this case on the refugees at Concord.

\footnotetext{
${ }^{4}$ Gookin, Doings and Sufferings, 495-96. I have adapted Gookin's account to a more narrative style to imagine how this event transpired. Gookin mentions the size of the crowd, but he does not flesh out the exact nature of this interaction. It is easy to imagine the fear that the Nashobahs experienced as such a large crowd surrounded the house they were in and called for them to come out. Similarly, Gookin stresses that the guards left to watch the Indians insulted them greatly. It is safe to say that the words selected above were probably hurled at the Indians, given the toxic invective against Indians which developed over the course of King Philip's War. This topic is addressed at greater length below in this chapter.

${ }^{5}$ Ibid., 455-62.
} 
The day he arrived at Concord Mosely and his men first stopped at the village meetinghouse to address the community once their religious service had ended. "I understand that this town is plagued by heathens under the protection of one Mr. Hoare," he said to the gathered crowd, "and if you would tell me where I might find them, I will remove them for you to Boston. For word has traveled to me that they are troubling you, and that you receive little rest with such foul neighbors living so close.” The church was deathly silent, though a few men encouraged him with shouts of consent and others gave tacit nods of approval. The next day a crowd of Concord residents accompanied Mosely and his men to the house within which they had confined Hoare and the captive Indians. Mosely called on Hoare again to deliver the Indians to him so that he could take them to Boston, but Hoare refused on the grounds that the captain held no formal charge to do so. Mosely retorted that he held a commission to destroy and kill the enemy, which he presumed sufficient cause when interpreted with a great deal of leeway. Hoare refused to give up the Nashobahs, so Mosely commanded his men to break down the door and seize the Indians inside. The door splintered and cracked as English hatchets fell upon it. As the door gave way, men streamed inside the cabin and seized the Indians inside, mostly women and children, binding their captives and dragging them screaming and struggling outside. The captured Indians watched in dismay as their tormenters pillaged what little belongings they had taken with them from Nashobah, despite the commands of Mosely to focus on the Indians and to stop looting. With a guard of twenty men, they trekked to Boston, where the court decided to confine them to Deer Island with the Natick and Punkapoag Indians, irrespective of the brash nature of Mosely's actions. Gookin wrote in his chronicle of the tribulations Praying Indians endured during the war that the Nashobahs went "to pass into the furnace of affliction with their brethren and countrymen." ${ }^{\circ}$ Despite their peaceful behavior and willingness to help their English ${ }^{6}$ Ibid., 495-97. 
neighbors, the Christian Indians of Nashobah - along with the other mainland Praying Indians were unable to override English hysteria and anger towards all Indians in the colony. It is with even greater irony that Mosely and his men first accosted them when they were most likely engaged in a shared religious ritual, albeit as a segregated gathering within their cabin.

The horrors of frontier violence unleashed during the course of King Philip's War presented grave consequences for the Indians who chose to inhabit Praying Towns and to ally themselves closely with men like John Eliot, Thomas Mayhew, and Daniel Gookin during the previous decades. Throughout the war, Praying Indians faced an increasingly hostile colonial body which moved to collapse the distinctions ministers and Praying Indians had sought to create through religious and cultural innovations that separated them from unchurched Indian polities. Praying Indians did not passively accept this hostility and attempted to demonstrate loyalty and a willingness to serve against Philip and the colony's enemies through particularly Indian and English signs of fidelity. Similarly, men like Daniel Gookin worked tirelessly to aid and defend the Praying Indians in the face of increasingly restrictive legislation, public outcry, and the stirrings of mob violence. Despite the efforts and accomplishments these Indian men, women, and children had displayed throughout their previous experience forging a covenanted church, which met puritan expectations for proper ecclesiastical polity, their experiences as wartime exiles left an indelible mark on the communities when they confronted the limits of colonial acceptance and inclusion.

This chapter begins with a narrative of the formative issues surrounding the outbreak of war along with the tangled interrelationship between Indian Christian communities, Philip's Wampanoags, and English colonists. John Eliot's efforts to negotiate diplomacy with Philip inserted Praying Indians into an antagonistic relationship with Philip, which proved devastating 
once open warfare began and Praying Indians found themselves facing the ire of traditionalists as well as the English. The chapter then explores the growth of English violence and hostility towards all Indians within the colony, paying close attention to the initial theological justifications for colonial actions and efforts to negate the claims articulated by Eliot, Gookin, and other missionaries that the Praying Indians were true, regenerate Christians. To accomplish this, I make use of wartime sermons to analyze their theological language and constructs to demonstrate the shifting status of Indians within New England puritanism and religious culture. These theological shifts also played out in the initial histories written about the war, such as William Hubbard's Narrative of the Troubles with the Indians in New-England, which frequently demeaned Indians and cast them as agents of Satan. This indictment of the missions program met with little overt resistance except for Daniel Gookin's Historical Account of the Doings and Sufferings of the Christian Indians in New England in the Years 1675-1677, which remained unpublished until 1836. Despite the failure of Gookin's account to find a widespread readership in a colony that remained hostile to Indians long after the war, the text represents a significant early American - and Native American - martyrology which highlights Indian suffering and English brutality in a pointed response to the unfolding changes within the colony. ${ }^{7}$

With the end of formal warfare in New England by 1678, colonists could turn their attention to rebuilding and restoring their communities after the tumult and bloodshed had subsided. Praying Indians faced a similar situation, intensified by their forced relocation and the wanton disregard many colonists had for their personal property during the bivouac and internment on Deer Island. The remainder of the chapter is devoted to an exploration of Indian

\footnotetext{
${ }^{7}$ Gookin himself directly refers to Sassamon as the "first Christian martyr of the Indians; for it is evident he suffered death upon the account of his Christian profession, and fidelity to the English," which places his text in the vein of other accounts of martyrdom and suffering for the faith, an important point which this chapter considers in greater detail later. Gookin, Doings and Sufferings, 440.
} 
efforts to rebuild communities and forge new connections in response to the changed colonial environment after King Philip's War, which included the deaths of their strongest supporters and English allies. At the same time, war transformed the religious landscape and greatly impacted theological conceptions of salvation for Indians in the face of new racialized impulses. This development held particular implications regarding the status of Indian Christians within the ecclesiastical body of the colony when coupled with the growing racialized discourse of indigenous barbarity. Imagining that Indians were permanently barbaric and forever barred from a true or authentic relationship with God became easier as a result of the war. In order to better elucidate the changes brought about by King Philip's War, we must first explore the relationship between Philip and the Massachusetts Bay Colony and his tangled interactions with the Praying Indians.

\section{Besieged on All Sides: Philip in 1675}

After decades of interaction which included arguments pertaining to land ownership, attempts to impose foreign legal constructs upon them, cultural differences which seemed insurmountable at times, and sporadic moments of violence, the Wampanoag sachem Philip and his followers likely felt that enemies abounded on all sides. Philip could easily reflect on his childhood and memories of the sachemship under his father Massasoit in comparison to the situation confronting him in the early 1670s with disdain. For their part, the English remained constantly on edge with rumors of French whispers and schemes to incite Indians within New England to armed rebellion, which prompted colonial authorities to press nearby sachems for acts and words of fidelity beginning in $1671 .{ }^{8}$ Indian populations had declined significantly over

\footnotetext{
${ }^{8}$ Douglas Edward Leach, Flintlock \& Tomahawk: New England in King Philip's War (Woodstock: Countryman Press, 2009), 15-30. In his seminal military history of King Philip's War, Leach tends to portray conflict as
} 
the course of colonization as disease took its toll: Daniel Gookin reckoned that the Narragansett had about one thousand warriors in 1674 compared to about five thousand before the English arrived, with comparable figures noted throughout eastern New England. ${ }^{9}$ Decline was a serious concern in light of English actions against the Pequot in the 1630s and regional tensions with the Narragansett and Mohegan, which had continued in various forms for decades afterward. In this unstable climate, Philip and other Indian sachems in the region carried out a tense series of moves and countermoves in an effort to play Indian enemies and colonial authorities off of each other. $^{10}$

When Philip came of age and inherited his sachemship, he assumed authority within a polity that faced the issues listed above, as well as the threat of fellow Indians whom Philip and others probably viewed as defectors or traitors: Indians who were willing to abandon aspects of their culture in "Praying Towns," and who forsook the manitou of their fathers in favor of English manitou. Thus, Praying Indians formed an important third faction within colonial politics and negotiations. In some cases, the English had carved towns such as Dedham from

\footnotetext{
inevitable due to the great cultural differences between Indians and Englishmen, despite his efforts to give due coverage to both parties as historical actors. More recent historians of Native America have tempered this assessment with a multitude of examples where collaboration and creative solutions to problems achieved through a cultural or political "middle ground." In "Symbol of a Failed Strategy: The Sassamon Trial, Political Culture, and the Outbreak of King Philip's War," James Drake states that "many researchers have demonstrated that Indians usually received unfair treatment in the colonial courts," which led him to question why war broke out at this particular time after the Sassamon trial. Rather than viewing conflict as a teleological inevitability, it is worth considering the circumstances which led Philip to war rather than attributing it to fate. James Drake, "Symbol of a Failed Strategy: The Sassamon Trial, Political Culture, and the Outbreak of King Philip's War," American Indian Culture and Research Journal 19 (1995): 111. Likewise, the fact that historians emphasize the culture of difference and proto-racism which emerged from the horrors of this frontier conflict necessarily suggests that the tendency before King Philip's War was to downplay or work around such differences. For statements on the profound change the war brought, see Leach, Flintlock \& Tomahawk, viii-ix, 242-250. Jill Lepore, The Name of War: King Philip's War and the Origins of American Identity (New York: Vintage Books, 1998), 45. Daniel R. Mandell, King Philip's War: Colonial Expansion, Native Resistance, and the End of Indian Sovereignty (Baltimore: Johns Hopkins University Press, 2010), 1-4, 119. Jenny Hale Pulsipher, "Massacre at Hurtleberry Hill: Christian Indians and English Authority in Metacom's War," The William and Mary Quarterly 53 (1996): 486.

${ }^{9}$ Daniel Gookin, Historical Collections of the Indians in New England. Of Their Several Nations, Numbers, Customs, Manners, Religion and Government, Before the English Planted There, in Collections of the Massachusetts Historical Society, I:I (Boston, 1792), 148. Gookin estimated that the Massachuset had declined from roughly three thousand men and their families to roughly three hundred men and families.

${ }^{10}$ Drake, "Symbol of a Failed Strategy," 126.
} 
Wampanoag territory and then further subdivided this land to create Praying Indian havens like Natick, giving Philip yet another reason to dislike these new polities. ${ }^{11}$ The English also demonstrated a willingness to extend favorable overtures to traditional enemies of the region, such as the Mohawk, when a preliminary mission was launched by six or seven Indians who "took with them Indian bibles, primers, catechisms, and other books, translated into the Indian language, and other things to present to those Indians," although no significant gains had yet to develop from this effort. Again, Praying Indians were at the vanguard of threats to Wampanoag power. ${ }^{12}$ John Eliot also pushed to found a string of new missions in Nipmuc territory in cooperation with indigenous ministers, which further extended the influence of Indian Christians to the new towns of Maanexit, Quinnatisset, and Wabaquasset, and threatened to undercut the tributary system which supported sachems like Philip and provided them with the means to carry out diplomatic reciprocity through the giving of goods. ${ }^{13}$ Similar missions grew in New Plymouth near Philip's territory, and Daniel Gookin attested in 1674 that "some have hopes of their greatest and chiefest sachem, named Philip, living at Pawkunnawkutt. Some of his chief men, as I hear, stand well inclined to hear the gospel."14 If Gookin is accurate in this description, then Philip had good reason to worry that he might lose his grip on the sachemship if people defected and splintered his territory into smaller Praying Towns which would no longer give tribute to Philip. The English had supported this breach in tributary payments as a means of

\footnotetext{
${ }^{11}$ Mandell, King Philip's War, 39-42. Leach, Flintlock \& Tomahawk, 15. James Drake provides further context for the relationship with Dedham as he details a brief conflict over settlement on a portion of the Dedham grant called Wollomonuppoag where the Pokanoket, a tributary of Philip, had lived. Drake states that "the currency-poor Philip shrewdly realized that he might receive payment in return for a release of Indian claims to the area and offered to sell the land in 1669. Thus, Philip capitalized on a difficult situation; in selling the land, he acquired currency that could be used to purchase trade goods." Drake, "Symbol of a Failed Strategy," 124-5.

${ }^{12}$ Gookin, Historical Collections of the Indians of New England, 157. Gookin explains that this effort was aborted because "their pilot, as they pretended, fell lame or sick, and other difficulties presented," so they returned home (158).

${ }^{13}$ Ibid., 189-91.

${ }^{14}$ Ibid., 200.
} 
lessening the power sachems held over Indians interested in Eliot's missionary project: this monarchical tyranny subordinated well-intended Indians to "heathen" practices and beliefs as a hindrance to their gospel. Again, the Praying Indians and English missionaries were to blame and presented yet another grave challenge to the standing of Philip's Wampanoag within the region.

At the same time, Indian Christian ministers and complex cultural brokers like John Sassamon worked with Philip as tensions continued to rise in the years leading up to 1675 to pacify relations between Philip and the English. Sassamon's history and early life proved more complicated than most: his parents' conversion to Christianity and subsequent death left him as an orphan living in an English household; as he grew he learned the tenants of Christianity and gained literacy while serving as a schoolmaster for Natick and a student at the special Indian school at Harvard. In 1662 he entered the service of Philip's brother Wamsutta as a translator and scribe: a position he retained under Philip because he similarly recognized the value of an Indian fluent in Algonquian and English. He also continued in the role of Indian preacher and attempted to make inroads with the Wampanoag he served, which created a serious conflict of interest exacerbated by the tensions that continued to rise in the early 1670 s. ${ }^{15}$ Sassamon was further troubled when the Pokanoket reported in 1675 that Sassamon had attempted to defraud Philip of certain lands when Philip dictated his will to Sassamon. Coupled with his proselytizing, Philip decided to dismiss Sassamon from his service. Sassamon relocated to a cabin on Assowamsett Pond and continued in his role as Indian minister, working with the nearby Namasket Praying Indians. In January 1675 he almost certainly sealed his fate when he traveled to Plymouth to report to colonial officials that Philip was plotting to attack the English. Sassamon had become too great of a liability to Philip and his Pokanoket allies, especially since they appeared to be in the early stages of plotting some sort of attack, lending credence to

\footnotetext{
${ }^{15}$ Mandell, King Philip's War, 44.
} 
implications of murder once Indians near Middlesborough, Plymouth discovered his body under

the ice of Assowamsett Pond. ${ }^{16}$

Shortly after Indians discovered Sassamon's body and reported news of his death to colonial magistrates, an Indian named Patuckson blamed three Pokanokets loyal to Philip, named Tobias, Wampapaquan, and Mattashunannamo, for the murder, which prompted an investigation and trial in June 1675. Though items strewn about near Sassamon's corpse gave the impression that he had simply fallen into the river while fishing, Plymouth magistrates ordered an examination of Sassamon's body to determine if the rumor of murder was true. Over the course of the examination, the jury found that Sassamon's body bore a number of wounds along with a broken neck and swollen head, both of which could have easily occurred as a result of a treacherous slip and fall under the ice. ${ }^{17}$ In Flintlock \& Tomahawk, Douglas Edwards Leach also notes that witnesses who saw to the removal of Sassamon's body from the river observed that no water came from the mouth of the body, suggesting that Sassamon had been dead before entering the water. Had he indeed drowned, he would have choked down icy gulps of water and filled his lungs in his final moments, making this a critical piece of evidence to the Middleborough jury in the trial. ${ }^{18}$ The jury which decided the fate of the three accused men consisted of twelve

\footnotetext{
${ }^{16}$ Drake, "Symbol of a Failed Strategy," 127-28. Lepore, In the Name of War, 25, 36-39. Gookin, Historical Account of the Doings and Sufferings, 440. Gookin observes that after the death of Sassamon, Waban and other Praying Indians went to colonial magistrates twice for "fear that Sachem Philip and other Indians, his confederates, intended some mischief shortly to the English and Christian Indians" in the months directly leading up to the war (441). Mandell, King Philip's War, 43-44. Similarly, Increase Mather stressed that Sassamon was killed "out of hatred against him for his Religion, for he was Christianized and baptiz'd, and was a Preacher amongst the Indians." Conveniently ignoring Sassamon's efforts to function within both camps, Mather concluded that the principal reason for his demise lay in his effort to warn Plymouth of Philip's plot. Increase Mather, A Brief History of the Warr With the Indians in New-England (Boston, 1676), 11.

${ }^{17}$ Mandell, King Philip's War, 44. James Drake, "Symbol of a Failed Strategy, 128.

${ }^{18}$ Leach, Flintlock \& Tomahawk, 30-31. Daniel R. Mandell notes that this was the extent of the autopsy, and that Plymouth magistrates refused any further examinations of the course. It is difficult to determine what else the colonists could have found, given the medical knowledge of their day, so perhaps they considered the evidence weighty enough to proceed with a conviction and sentence for the Pokanokets under suspicion. Mandell, King Philip's War, 44. Regardless of the exact reasons, Jill Lepore rightly notes that any explanation ultimately is drawn to “the specter of John Sassamon's position as a cultural mediator, as a man who was neither English nor Indian but
} 
Englishmen and six "sage Indians," which historians agree were most likely Indian Christians familiar with English law and literate to a certain degree. On June 8, 1675, the English hanged Tobias and Mattashunannamo to carry out the guilty verdict, while Wampapaquan had a temporary stay of execution when his noose broke and he desperately confessed to watching the others kill Sassamon in a plea for mercy, though it did not prevent the English from shooting him a month later. ${ }^{19}$

On June 20 a group of Philip's warriors attacked the settlement of Swansea, looting abandoned houses left by colonists who feared their vulnerable position at the vanguard for any Indian attack. They had entered the house of an Englishman to have their hatchets sharpened, but he refused to work on Sunday and sent them out. The warriors set two other houses on fire as the terrified village remnant fled north to rally the rest of the community to a defense and to send a messenger on horseback to alert the colony's governor. As the villagers in the surrounding area regrouped around one of the garrisons in the region they waited for reinforcements, which arrived from nearby Bridgewater and Taunton. Violence escalated as warriors and garrison sentries exchanged fire and the warriors began killing the cattle and other livestock the villagers left behind. By June 24, warriors had killed nine colonists and convinced colonists across Plymouth that the dreaded Indian uprising had begun. ${ }^{20}$

\footnotetext{
who negotiated with both peoples." In this case, Sassamon's abilities as a "cultural broker" failed him when colonial tensions became too high to bear. Lepore, The Name of War, 25-26.

${ }^{19}$ Ibid., 44-46. Drake, "Symbol of a Failed Strategy," 129. Drake contends that this trial proved to be the catalyst for Philip's rebellion because it "symbolized the relative success of the praying Indians' strategy of encapsulation within the English political system - including the adoption of literacy and certain elements of Christianity - and the failure of the nonmissionized Indians' variant thereof." Given the long and contentious history of Indian-English relations within the colony over the previous decades, Drake makes a strong case for Philip's recognition of the Praying Indians as a rival faction and the symbolic meaning inherent in the Sassamon trial. Ibid., 129-133.

${ }^{20}$ Leach, Flintlock \& Tomahawk, 35-40. Mandell, King Philip's War, 48-51. Lepore, The Name of War, 23.
} 


\section{Ominous Signs and Penitential Offerings}

Natural wonders and phenomena served as significant portents in both English and Indian religious culture, so the appearance of a total lunar eclipse on June 26 after the Swansea attack likely served as validation for the Pokanokets and pushed other Indians who were hesitant to join in a widespread attack over to the militant camp. It certainly appeared as a sinister omen to the English who commented on it despite the fact that their almanacs accurately predicted its arrival: the vanishing sliver of the moon transformed the heavenly body first into an Indian scalp and then into a warrior's bow. Totally obscured, the eclipse blanketed the colonists in foreboding darkness. ${ }^{21}$ Though these initial attacks appear the result of hasty and insubordinate warriors who bucked Philip's authority, throwing the sachem into the fray without a comprehensive and coordinated plan, news of the attack and the omen quickly drew other Indians across southern New England into the conflict as the war widened and intensified and others gave vent to colonial frustrations. Wondrous signs and omens serve as a worthy introduction to an examination of puritan and Indian understandings of divine forces and human action in the context of war.

As the colonists struggled to gain an advantage during the early portion of King Philip's War and to adapt to Indian methods of warfare, they also grappled with a religious understanding of the war as they faced a series of losses without any significant victory. If God truly favored the puritans and had blessed them in their endeavors, then why had he subjected them to the

\footnotetext{
${ }^{21}$ Drake, "Symbol of a Failed Strategy," 131. Lepore, The Name of War, 23. Leach notes that tradition holds that Wampanoag powwows told Philip that they would win "only if the English fired the first shot." After antagonizing the English and drawing their fire, the appearance of an eclipse, which the Wampanoag may or may not have anticipated depending on their communication with the English, did indeed validate their plans. Leach, Flintlock \& Tomahawk, 42-43. In his account of the war, William Hubbard stressed that "although the mischief following was done by Guns, not by Bows," the significance of the eclipse still rang true. William Hubbard, A Narrative of the Troubles with the Indians In New-England, from the first planting thereof in the year 1607. to this present year 1677. But chiefly of the late Troubles in the two last years, 1675 and 1676. To which is added a Discourse about the Warre with the Pequods In the year 1637. (Boston, 1677), 18.
} 
horrors of frontier warfare, and why did they continue to lose? Turning to both puritan sermons delivered and printed during the war and early histories of the war reveals a puritan understanding of divine warfare and punishment, and the centrality of penitence and religious ritual to turn the tides of war. This religious understanding and supplication in the midst of war similarly contributed to the development of a theological distinction between Indians and Englishmen, which many New England ministers surmised to be a permanent marker of their innate barbarism, a subject explored in greater detail within the following section. Similarly, it is worthwhile to explore the situation of Praying Indians during the early period of war to determine their understanding of the conflict and similar efforts to protect their community and assuage God's wrath and punishment as participants within similar rituals. As hybridized communities practicing a colonial form of Christianity informed by Algonquian tradition, Praying Indians similarly understood the importance of ritual and penitence as a means of influencing divine outcomes. Indian ministers and their English allies approached the growing conflict intent on purifying their communities and assuaging God's wrath, which became increasingly difficult as the English expressed hatred toward all Indians regardless of their proclivity for praying or living as English allies in bounded towns like Natick.

As he reflected on the late war while penning a rebuttal to the early histories of King Philip's War generated by colonial presses, Increase Mather sought to devise God's providential stratagem and purpose over the course of the conflict in order to cull the parishioners of New England's churches toward godliness and, in his mind, away from renewed complacency now that the fighting had died down in Massachusetts and Plymouth. In his Brief History of the War with the Indians in New-England (1676), Mather noted that the colonial militia nearly captured Philip near the swamp of Pocasset on August 1, 1675, and almost "put an end to these tumults: 
but though Deliverance was according to all Humane probability near, God saw it not good for us as yet."22 Thus, for many of New England's ministers, divine providence served as a poignant explanation for the hardships, bloodshed, and profound losses that rocked the colony during the formative months of the conflict. Drawing on the biblical story of the Exodus, Mather concluded that $\sin$ bred by the founding generation in the colony ripened to produce "so dreadfull a judgment" for the second generation as a call to repentance, prompting English colonials to adopt a posture of penitence through a series of fast and thanksgiving days over the course of the war. This notion of divine punishment, penitential offerings to an angry and wrathful God, and the urgent need for repentance shaped puritan understandings of the origins and nature of the war, contributing to new theological constructs of Native Americans.

As violence broke out in June 1675 and more Indian communities joined Philip's faction or launched their own campaigns against nearby colonists, Massachusetts authorities sent Captain Edward Hutchinson, Ephraim Curtis, and three Indian guides (two of them identified as Praying Indians Joseph and Sampson), along with Captain Thomas Wheeler and some twenty troops, to the tiny community of Brookfield (Quabaug) in the heart of Nipmuc country on July $28^{\text {th }}$ in order to broker a truce with the Indians in this region. On August $2^{\text {nd }}$ the company set out to rendezvous with Nipmuc leaders but faced an enemy ambush as they passed through a swamp, forcing them to hastily retreat to Brookfield and garrison themselves in one of the village houses in what Douglas Edward Leach calls “one of the classic sieges of New England's history." For two days the English sustained heavy gunfire and jeering from the well-armed Nipmuc, who

\footnotetext{
${ }^{22}$ Mather, A Brief History of the Warr, 15. Slotkin and Folsom explain the importance of biblical teleology within Mather's historical writings, arguing that Mather saw "in temporal history only endlessly (perhaps absurdly) recurring cycles" which echoed the covenantal drama of the Old Testament. The purpose of events like King Philip's War served as didactic messages pointing the puritans towards the telos and culmination of Revelation. Richard Slotkin and James K. Folsom, eds. So Dreadfull a Judgment" Puritan Responses to King Philip's War 1676-1677 (Hanover: University Press of New England, 1978), 57-59.
} 
taunted the English as they prayed for deliverance with retorts like "now see how your God delivers you, or will deliver you," as they continued to shoot at the soldiers and set fire to the houses in Brookfield in an effort to drive the garrisoned soldiers and villagers out of their house. The English narrowly escaped and frequently cited this incident as proof of Indian perfidy, as the Nipmuc surrounding Brookfield lived harmoniously with their English neighbors for years before the war. ${ }^{23}$

Writing about the siege in 1676, Thomas Wheeler marveled at God's deliverance of the company and attempted an interpretation of these attacks by the "Heathen who hates us without a Cause," arguing that God masterminded these horrors so that they might "humble ourselves before him, and with our whole hearts to return to him, and also to improve all his mercies which we still enjoy." Once true penitence had been offered to God, Wheeler concluded that God's anger would subside and that he "may be pleased either to make our Enemies at peace with us, or more, destroy them" as a fitting resolution for Wheeler and the men who survived this battle. ${ }^{24}$ In the sermon included with Wheeler's narrative, Edward Bulkley chose the text of Psalm 116:12 as his focus, which read "What shall I Render unto the Lord for all his Benefits towards me." David's traditional connection with this psalm as author led Bulkley to also draw heavily on Psalm 18, in which David thanked God for delivering him from King Saul, his men, and "all

\footnotetext{
${ }^{23}$ Leach, Flintlock \& Tomahawk, 77-84. Leach provides a visceral narrative of the siege at Brookfield, which provides contextual background for the analysis of the later account written by Thomas Wheeler and the thanksgiving sermon preached by Edward Bulkley. Thomas Wheeler, A Thankfull Remembrance of Gods Mercy to several Persons at Quabaug or Brookfield: Partly in a Collection of Providences about them, and Gracious Appearances for them: And partly in a Sermon Preached by Mr. Edward Bulkley, Pastor of the Church of Christ at Concord, upon a day of Thanksgiving, kept by divers for their Wonderfull Deliverence there. (Cambridge, 1676), 6. Daniel Gookin includes a certificate from Thomas Wheeler attesting to the courage and faithfulness of Joseph and Sampson in their efforts to lead the company out of the swamp in the remove to Brookfield. During the attack, Wheeler swore to Gookin that they "behaved themselves as honest and stout men," which Gookin later used in his defense of the Praying Indians. Gookin, Doings and Sufferings, 448.

${ }^{24}$ Ibid., 9-10.
} 
others that sought his Ruine." ${ }^{25}$ Bulkley’s readers were naturally drawn to place themselves in the position of David and to imagine their Indian enemies as Saul's men or, more fittingly, as the Philistines. Despite their temporal woes, Bulkley urged his listeners and readers to thank God for their spiritual blessings, chiding them for failing to adequately do so in the past. Reminding his readers that God would reciprocate when heartfelt penitence was offered, he stated that "God will not take away his mercies from us, from the Country, if we Return praise to him; They giving God his Rent, the Tribute he expects, he will not turn them out of doors." By praying and singing with pure hearts, this would "open God's heart and hand to give more" and turn the tide of battle against "the Children of Ammon.",26

This account of the Brookfield skirmish by Wheeler, and the companion sermon by Bulkley, serve to highlight a common puritan understanding of the early war and their sense of available actions amidst a series of losses. Throughout the course of the war, New England's ministers sounded a common refrain of repentance for past sins. Thus, when he delivered the Election Day sermon on June 5, 1676, Samuel Willard summoned martial imagery to liken an unsubordinated spirit to a city breached during war because it lacked walls. Willard reminded his listeners that Jesus was a conquering king, undefeated in battle, and that the church was to be militant: "every man indeed is a Souldier, either under Christ or the Devil; Engaged in a Warr,

\footnotetext{
${ }^{25}$ Ibid., 2. Numbering for this text begins again once the document transitions from Wheeler's narrative to Bulkley's sermon. This footnote thus refers to Bulkley's contribution to the text. Well-read puritans who memorized extensive passages in the Psalms might also recall the verse before Bulkley's primary text (Psalm 116:11) when thinking of Indian perfidy, which read: "I say in my fear, All men are liars."

${ }^{26}$ Ibid., 28-29. Bulkley referenced 2 Chronicles 20:22 within this text, which read "And when they began to shout, and to praise, the Lord laid ambushments against the children of Ammon, Moab, and mount Seir, every one helped to destroy another." He clearly intended to encourage the colonists to pray and turn to God in order to defeat their opponents, possibly through internal factionalism. Bulkley thus read the diversity of Indian geopolitics into the typology of biblical Canaan. In the context of Mary Rowlandson's later account of captivity, Matthew P. Brown notes the importance of a phenomenology of book history and the act of reading, arguing that the responsive nature of sermonic literature encouraged participation from the reader or listener which ministers sought to control through sections within the sermon denoting "use" or application." Despite this attempt at ministerial guidance, creative readers or listeners might appropriate ideas or mold them to their own use, as with Anne Hutchinson in the 1630s. Matthew P. Brown, The Pilgrim and the Bee: Reading Rituals and Book Culture in Early New England (Philadelphia: University of Pennsylvania Press, 2007), ix-xiv, 108, 137-38.
} 
which will issue either his Happiness or Ruine." Though the tide of the war had turned by June 1676, Willard urged his listeners to "beware of growing Secure and Remiss" in the face of victory, and to continue to rely on God's divine assistance in the war with thankfulness, for "you shall shortly see all your Enemies dead at your feet." ${ }^{27}$ A month earlier at the Boston election day, William Hubbard preached a sermon on the necessity of good rulers and leadership, drawing on the examples of David and Gideon: two biblical figures who led Israel to victory and averted war. Reminding his listeners that they were fighting a war in which they "have neither promise nor probability of success," he urged Boston to reflect on "the solemn Dispensation of God to our selves in the present war with the Indians, that we must say, the God of our Salvation hath not answered us, but by terrible things in righteousness." ${ }^{28}$ Even after the main part of the war ended, puritan ministers continued to interpret the war as a divine form of punishment, drawing on allusions from the Old Testament's history of Israel and God's antagonistic relationship with a people prone to disobedience in an effort to encourage penitence and religious reform. ${ }^{29}$

\footnotetext{
${ }^{27}$ Samuel Willard, The Heart Garrisoned OR, The Wisdome, and Care of the Spiritual Souldier above all things to safeguard his Heart (Cambridge, 1676), 1, 6, 12, 19-21.

${ }^{28}$ William Hubbard, The Happiness of a People In the Wisdome of their Rulers Directing and in the Obedience of their Brethren Attending Unto what Israel ought to do: Recommended in a Sermon Before the Honourable Governour and Council, and the Respected Deputies of the Mattachusets Colony in New-England. Preached at Boston, May 3d. 1676. Being the day of Election there. (Boston, 1676), 19-20, 47.

${ }^{29}$ For more examples of this vein of puritan thought, see John Wilson's sermon against Quakerism, which was printed in 1677 after he delivered it in 1665. New England puritans apparently saw the threat of Quakerism and a number of monstrous births (undeveloped or malformed fetuses delivered prematurely) as warnings from God to triumph orthodoxy in the colony. The implication of this sermon, along with its timing, is that the failure to combat Quakerism was but one of the reasons for God's punishment in King Philip's War. John Wilson, A Seasonable Watch-Word Unto Christians Against the Dreams \& Dreamers Of this Generation: Delivered in a Sermon November $16^{\text {th }}$ 1665. And being the last Lecture, which was Preached By that Reverend, Faithful and Eminent Man of God Mr. John Wilson. Sometime Pastor of the Church of Christ in Boston in New-England. (Cambridge, 1677), ii, 3, 8. Similarly, Samuel Hooker warned the election day audience at Hartford in 1677 that God is "one in a peculiar manner to bare witness against the wantonness and sins of his Covenant people, that have been singularly favoured and priviledged by him." Though New England might rejoice at Philip's death, God "hath further, sorer punishments to inflict on a people, that by a process in sin carry on the provocation." Samuel Hooker, Righteousness Rained from Heaven, Or A Serious and Seasonable DISCOURSE Exciting all to an earnest enquiry after, and continued waiting for the effusions of the Spirit, unto a communication and increase of Righteousness: That Faith, Holiness, and Obedience may yet abound among us, and the Wilderness become a fruitful field, As it was Delivered in a Sermon
} 
As puritan ministers crafted an understanding of the origins of King Philip's War steeped in Old Testament biblical narrative, with frequent allusions to Israel's wanton commitment to their covenant with God, they also encouraged a ritualistic form of supplication in order to turn the tide in the war, defeat their enemies, and restore God's favor with the New England colonies. Alternating between days set aside for fasting or for giving thanks to God, New England's ministers and magistrates discouraged rote participation, like the fasting and reform under King Hezekiah, for "there are many mock-services whereby mock-Christians mock God in their profession," further provoking their god to righteous punishment and anger. Thus, ministers stressed the necessity of inward and heartfelt penitence while they simultaneously committed to regular rituals of supplication. ${ }^{30}$ Similarly, Increase Mather's history of the war revolves primarily around a series of fasting and feast days to punctuate the major skirmishes of the war, while also highlighting the fact that Indian attacks often occurred on these very holy days when puritans cautiously ventured out of their homes to attend services at the local meetinghouse. The potent symbolism in these attacks, like when Deerfield (Pacomptuck) was burned to "ruinous heaps" on September 1, 1675, led Mather to exclaim: "That which addeth solemnity and awfulness to that Desolation, is, that it happened on the very day when one of the Churches in Boston were seeking the face of God by Fasting and Prayer before him."31

Amidst these religious tribulations, Praying Indians from various towns joined together in their own fast days and penitential rituals as a sign of religious solidarity with the plight of their

Preached at Hartford on Connecticut in New-England, May 10. 1677. Being the Day of Election there. (Cambridge: 1677), i, 3, 8.

${ }^{30}$ Thomas Thatcher, A Fast of God's chusing, Plainly opened, For the Help of those poor in Spirit, whose hearts are set to seek the Lord their God in New-England, in the solemn Ordinance of A Fast. (Boston, 1678), 2, 20. Thatcher delivered this sermon on Isaiah 58:5, 6 at a public fast held in January 1674.

${ }^{31}$ Increase Mather, A Brief History of the Warre, 18. For more examples of fast and feast days, along with Mather's interpretation of God's displeasure with them, see pg. 30, 32, 34, 39, 41. Jill Lepore has also argued that Indians understood Puritan theology and religious ideas well enough to capitalize on their fear of God's displeasure by utilizing Sabbath days as a way to systematically demoralize them and undermine their will to fight. Lepore, The Name of War, 97-99, 104. 
English brethren and as an effort to similarly purge their communities of sin and avert further punishment and wrath from God in the face of widespread warfare. These actions augmented more pragmatic expressions of fidelity and drew on the Praying Indian identity as true converts to Christianity. Daniel Gookin recorded that the Praying Indians "had put themselves into a posture of defence, and had made forts for their security against the common enemy" at the beginning of the war. In addition to this move of self-defense, they also asked the magistrates to send Englishmen to join them at these forts in an effort to secure the colonial hinterland, which Gookin stressed was "the earnest desire of some of the most prudent of the Christian Indians, who in all their actions declared that they were greatly ambitious to give demonstration to the English of their fidelity and good affection to them and the interest of the Christian religion." Interpreting the effects of the war, Gookin linked the fates of both English and Indian Christians, arguing that "the purging and trying the faith and patience" of them "certainly was another end God aimed at in this chastisement. ${ }^{\prime 32}$ Throughout their tribulations, Gookin and Eliot attempted to console and encourage the Praying Indians as colonists grew increasingly hostile towards all Indians within their domain. As Indians prepared to remove to Deer Island, Eliot met a number of them at a place called "the Pines" to encourage them with tearful prayers, as they feared "that they should never return more to their habitations, but be transported out of the country."33

By August 1675, common and widespread English fears regarding the loyalty of the Praying Indians led magistrates in Massachusetts to order two or three Englishmen to serve as observers at each of the Indian towns, though they managed to convince only two men, John Watson, sr., and Henry Prentiss, to reside at Natick, and a small, rotating group of men to observe at Punkapoag for a number of weeks before the colony interred them at Deer Island.

${ }^{32}$ Gookin, Doings and Sufferings, 436, 438.
${ }^{33}$ Ibid., 474. 
Gookin solicited Watson and Prentiss to write a certificate regarding the conduct of the Praying Indians at Natick, wherein they stated that "they behaved themselves both religiously towards God, and respectively, obediently, and faithfully to the English." He further contended that the behavior of the Praying Indians convinced Watson to abandon his previous pattern of prejudice toward the Christian Indians in favor of defending them before the Massachusetts governor and General Court. ${ }^{34}$

Unfortunately, these actions and efforts to draw on their identity as Indian Christians came to naught in the toxic theological environment created by the realities of warfare and the mental framework by which puritans understood and fought the war in New England. By focusing on their own perceived failings and efforts to understand the reasoning behind God's hellish punishment on English settlements across the colony, puritans drew on ready theological constructs to frame their understanding of the war. Furthermore, the brutality of warfare created tangible images of ruin and desolation in the minds of puritans as homes were immolated, stripped and scalped bodies moldered where they fell, fields lay fallow and smoldering, and Indians continued to terrify and push the vanguard of colonial settlement back toward the Atlantic. Thus, the theological middle ground which afforded a positive religious identity for Indians within New England during the apocalyptic fervor of the English Civil War - that of the millennial gentile or restored Jew - collapsed in favor of a new identity which threatened to cast all Indians as degenerate barbarians.

${ }^{34}$ Ibid., 452. 


\section{Developing a Theology of Difference and Exclusion: King Philip's War as Typological Conflict}

Since they arrived in North America to plant a "city on a hill," New England puritans constructed typological scripts which they utilized to make decisions and interpret events that unfolded in the decades leading up to King Philip's War. Scholars have long recognized the performative and theatrical elements of puritan piety, and have appropriately emphasized the significance of their desire to live out Old Testament narratives as a "new English Israel" as a formative element of the puritan experience establishing colonies in North America. ${ }^{35}$ As puritans sojourned into an American "wilderness," they imagined themselves reliving the experiences of the Israelites in the deserts of Canaan. When confronted with antinomianism, they could mentally and rhetorically draw on the more immediate legacy of European Reformations or fall on the patristic legacy of the early Church Fathers in their efforts to combat heresies like donatism or Arianism. As news from England traveled transatlantic networks to deliver word on the progress of the English Civil War and the puritan legacy of Cromwell's Protectorate, men like John Eliot imagined themselves living within the eschatological framework of the Book of Revelation as they saw apocalyptic prophecies realized in day to day events. This potent reliance

\footnotetext{
35 The "new English Israel" quotation comes from an artillery sermon delivered by Cotton Mather during King William's War in 1689, which will be examined in greater detail within the context of developments during King Philip's War discussed in this section. Cotton Mather, Soldiers Counselled and Comforted: A Discourse Delivered unto some part of the Forces Engaged in the Just War of New-England Against the Northern \& Eastern Indians. (Boston, 1689), 35. For more on the importance of material symbolism within puritanism, see Ann Kibbey, The Interpretation of Material Shapes in Puritanism: A Study of Rhetoric, Prejudice, and Violence (Cambridge: Cambridge University Press, 1986), 42-64. The puritan interpretive focus on the Old Testament is most adequately discussed in Mason I. Lowance, Jr., The Language of Canaan: Metaphor and Symbol in New England from the Puritans to the Transcendentalists (Cambridge: Harvard University Press, 1980), 28-40, and in Theodore Dwight Bozeman, To Live Ancient Lives: The Primitivist Dimesion in Puritanism (Chapel Hill: University of North Carolina Press, 1988), 32-50. In his preface to a collection of works by Thomas Shepard, Michael McGiffert writes: "God's plot was the great plan of human salvation...Shepard and his people envisioned a divine scenario governing the living of their lives and the saving of their souls. They became actors with parts to play in a cosmic drama of redemption. God wrote the script, cast the parts, directed the staging; Christ took the starring role; religion explained each act and scene.... These were constituent and dynamic elements of Puritan spirituality." Michael McGiffert, ed. God's Plot: Puritan Spirituality in Thomas Shepard's Cambridge. Revised and Expanded Edition (Amherst: University of Massachusetts Press, 1994), ix.
} 
on biblical script also held great significance for waging war, as puritan scriptures provided a wealth of stories and images from which to draw and frame a narrative. Thus, this important theological component to fighting and interpreting King Philip's War as it unfolded across New England held great importance not only in its governing influence in how puritans understood the war and their enemies, but for Praying Indians and their conceptual place within the ecclesiastical body of the wider colony.

While puritan ministers stressed that violence at the hands of Indians was God's punishment for the sins of the colony's rising generation in the months leading up to and following the outbreak of King Philip's War, they simultaneously offered a justification for their part in the war by framing the conflict on biblical precedent to fit emerging juristic conceptions of a "just war." 36 In his sermon on covenant renewal delivered in 1677, Increase Mather drew on the story of Jephthah from Judges 11 and 12 as an illustration for the important link between covenants and warfare: "when he [Jephthah] was greatly distressed by reason of the Heathen who made an unjust Warr upon him, that put him upon solemn vowing to the Lord, and so renewing his Covenant in that way." The clear allusion to the present conflict in New England is unmistakable, casting Indians as heathens waging an unjust war and puritans as just in their defense. ${ }^{37}$ Early narratives of the war similarly stressed the just defense of the puritans, as Benjamin Thompson wrote in his poetic New Englands Crisis:

\footnotetext{
36 Jill Lepore stresses that many colonists were "plagued with doubts about the justness of their war, especially early on," though these doubts abated once the tide had clearly turned in favor of the English. Lepore rightly notes that Puritans relied heavily on the doctrine of "just warfare" articulated by Hugo Grotius in his De Jure Belli Et Pacis in 1623. Lepore, The Name of War, 106-113. For a fantastic overview of Grotius's legacy in the context of international law and warfare, see the chapter devoted to Grotius in Richard Tuck, The Rights of War and Peace: Political Thought and the International Order from Grotius to Kant (Oxford: Oxford University Press, 2009), 78108.

${ }^{37}$ Mather, Renewal of Covenant, 8. Mather followed this example with two more examples from Old Testament history where covenants accompanied just wars against infidel enemies, drawing on Numbers 21:1,2 and Deuteronomy 29:1. The example of Jephthah is particularly significant because in the story Jephthah makes an oath to God that he will sacrifice the first person who comes out of his house to meet him after victory over the
} 
And every soul which hath but common sence

Thinks it the time to make a just defence. ${ }^{38}$

Similarly, in his Brief History of the Warr, Increase Mather declared: "no man can doubt of the justness of our cause, since the enemy did shed the blood of some of ours who never did them the least wrong before we did at all offend them, or attempt any act of hostility towards them."39 Both Mather and Thompson ignored grievances raised by Philip and other Indians prior to the war in favor of defending their wartime conduct, which coincides with Jill Lepore's analysis of wartime writing as a means of sanitizing and downplaying puritan atrocities in an effort to reinforce unstable colonial identities. ${ }^{40} \mathrm{By}$ the end of the war, reliance on rhetoric of just warfare became common parlance, as Samuel Nowell wrote in his famous martial sermon Abraham in Arms: "Hence our late War was justifiable, though the Quarrel was firstly with our neighbours." Nowell penned these words in an interpretation of Abraham's taking up arms in order to rescue his cousin Lot and family from captivity, continuing this interpretation of King Philip's War with the following: "Hence consequently, it is lawfull by war to defend what we have lawfully obtained and come by, as our possessions, lands and inheritance here, to which we have as fair a title as any ever had, since Israels title to Canaan."41 As with Mather's examples, Nowell

\footnotetext{
Ammonites, which ironically is his only child: a virgin daughter. Jephthah remains true to his word and sacrifices his daughter, which leads the daughters of Israel to devote four days in a year to lament Jephthah's daughter. Even at the utmost cost, Jephthah remained true to the covenant of renewal which he swore to God, a point which Mather hoped to emphasize in the context of New England's war.

${ }^{38}$ Benjamin Thompson, New Englands Crisis: Or a Brief Narrative, Of New-Englands Lamentable Estate at present, compar'd with the former (but few) years of Prosperity. Occasioned by many unheard of Crueltyes practised upon the Persons and Estates of its united Colonyes, without respect of Sex, Age or Quality of Persons, by the Barbarous Heathen thereof. Poetically Described. By a Well wisher to his Countrey. (Boston, 1676), 13.

${ }^{39}$ Increase Mather, Brief History of the Warr, 13. Ellipsis removed from the original quote for clarity. Between did them/the least reads: "(our enemyes themselves being judges)".

${ }^{40}$ Lepore, In the Name of War, 12-13. Lepore is most insightful in her analysis of the language surrounding the Narragansetts' Great Swamp Fight on December 19, 1675 and its usefulness to mute the reality of a massacre of women and children through language which downplayed the reality of Indian settlement to fit conceptions of just warfare. See pages 84-89.

${ }^{41}$ Samuel Nowell, Abraham in Arms, Or The First Religious General With His Army Engaging in A War For which he had wisely prepared, and by which, not only an eminent Victory Was obtained, but A Blessing gained also. Delivered in an Artillery-Election-Sermon, June 3. 1678. (Boston: 1678), 3-4. In her chapter on masculinity in
} 
projected Old Testament typologies onto the contemporary conflict and encouraged puritan listeners and readers to imagine themselves in the company of Abraham and other biblical warriors who engaged in holy wars against heathen enemies over land that was theirs by right of solemn covenant with God. ${ }^{42}$

If this typological reading of colonial warfare formed the setting and context for King Philip's War, it also provided a plot mechanism by which barbarian Indians served as a tool at God's disposal to wield against the colonists in order to scourge them to repentance. Another competing or interchangeable interpretation of Indian actions posited that they were barbarians under the captivity of Satan, left unchecked by God in order to satisfy his punishment against the colonists. In his election day sermon at Hartford in 1677, Samuel Hooker urged his listeners to recall how God utilized "the Inrode of the Heathen" to punish Israel according to the text Hosea 10:12. When facing God's wrath, "the Assyrian is the rod of his anger, and the staffe in their hand is his indignation, they move not til he sendeth, they make no spoile until he giveth the word of command." ${ }^{43}$ Hooker thus impressed upon his listeners and readers the refrain of biblical typology: Indians were likened to the Assyrians or Moabites to be loosened upon the Englishmen for their spiritual betterment, despite the horrors of warfare. Bill Templer argues that "the Joshua mythologeme is indeed intrinsic to Puritan thought and action from 1630 well into the following

puritan warfare, Ann M. Little also highlights the importance of a just defense in warfare and this technique within Nowell's sermon. Ann M. Little, Abraham in Arms: War and Gender in Colonial New England (Philadelphia: University of Pennsylvania Press, 2007), 24.

${ }^{42}$ King Philip's War clearly served as the formative setting for the development of this template for warfare. By the time King William's War began in 1688, New England colonists could easily redeploy this rhetoric to fit the latest frontier conflict which arose. Cotton Mather makes similar arguments in his sermon Soldiers Counselled and Comforted. Mather also goes above and beyond writers during King Philip's War to cast this later conflict as a holy war. See Mather, Soldiers Counselled and Comforted, 29-30, 32-33.

${ }^{43}$ Hooker, Righteousness Rained from Heaven, 1. Hosea 10:12 reads "For it is time to seek Jehovah until he come and rain righteousness upon you." Hooker also reinforced this point with the text of 2 Kings 24: 2, 3: "And the Lord sent against him bands of the Chaldeans, and bands of the Aramites, and bands of the Moabites, and bands of the Ammonites, and he sent them against Judah to destroy it, according to the word of the Lord, which he spake by his servants the Prophets. Surely by the commandment of the Lord came this upon Judah, that he might put them out of his sight for the sins of Manasseh, according to all that he did." 
century," and that typological hermeneutics served as "the interpretive linking between the visible and invisible worlds, the temporal and the eternal," which led puritans to decode "present events and persons as 'antitypes' of happenings and figures largely from Hebrew scripture." ${ }^{44}$ As the war raged, men like William Hubbard could imagine themselves driving their enemies back across the "desert woods," a strange description which sought to merge North American geography with biblical imagery ${ }^{45}$ Increase Mather similarly urged his audience to recall the story of Nehemiah in his covenant sermon when he argued that Israel under Nehemiah was "delivered from the Heathen Nations, who had sorely wasted and destroyed them, in order to a Reformation of those evils that had provoked the Lord against them." ${ }^{.46}$ Further in this sermon Mather stressed orthodox Calvinist doctrine when he stated that "natural man is a servant to sin and Satan, and not to God," offering still later an interpretation of the war: "therefore hath the Lord ben whetting his glittering Sword, and his hand hath taken hold of Judgment, he hath made his arrows drunk with bloud, and his Sword hath devoured Flesh. ${ }^{" 47}$ Colonists could implicitly connect "natural man" with Indians who, with their unchurched status and cultural differences, fit this conception and were thus firmly in Satan's grasp. Furthermore, the imagery of bloody arrows would immediately draw one's mind to Indians in this context.

Nowell made the Indian connection even more explicit in Abraham in Arms when he argued that God allowed the people of Canaan to remain unsubdued in order to teach Israel the art of war. With this in mind, he stated: "so the Lord hath dealt with us by his Providence here in this wilderness, these are the Nations which the Lord left to prove Israel by, those that had not

\footnotetext{
${ }^{44}$ Bill Templer, "The Political Sacralization of Imperial Genocide: Contextualizing Timothy Dwight's The Conquest of Canaan," Postcolonial Studies 9 (2006): 369. While concerned primarily with Dwight's 1785 poem describing epic millennial warfare in the context of the American Revolution, he offers a succinct reading of this typological conquest narrative from the Pequot War through frontier conflicts, conceptualizing King Philip's War as the first true ethnic cleansing against Indians in the American colonies. See pg. 363-371.

${ }^{45}$ Hubbard, The Happiness of a People, 60.

${ }^{46}$ Increase Mather, Renewal of Covenant, 1.

${ }^{47}$ Ibid., 11, 13.
} 
known the Wars of Canaan." ${ }^{48}$ Likewise, John Richardson's sermon on the need for soldiering delivered in June 1675 stressed that skill in warfare was imperative "while Sin and the Sons of Anak are unsubdued, while the Philistins are in the Land."49 Reflecting on biblical history, Richardson wrote: "The Bow was a principall Instrument then used in their wars, by the more acute, nimble and skilfull managing whereof the Philistims [very likely] then gained their Victory over Israel," which provides yet another obvious connection between Indians and the Philistines. Continuing his sermonic history lesson, Richardson stated that David made use of his enemy's weapons to win the war, and that the colony should utilize the same tactic in order "to match, or rather excel them in their own Art." ${ }^{50}$ Again, biblical typology provided a template by which New England ministers could superimpose the role of the Old Testament barbarian upon their Native American enemies.

While ministers offered a more cerebral, and often sanitized, description of their enemies in the context of sermons that focused primarily on the spiritual state of parishioners, the earliest histories of the war similarly relied on the language and trope of Indian barbarism while positing a competing theological claim. Rather than simple barbarians or pawns at God's disposal for the spiritual regeneration or punishment of an angry God, these authors argued a more nefarious thesis: the machinations of the Devil enslaved them fully and totally. In this sense, they were acting out their natural, unregenerate ways and barely more than animals, which accounts for the predominance of animalistic language and imagery in descriptions of violence during King Philip's War. In his account of the siege at Brookfield, Thomas Wheeler utilized such a vocabulary, which included words such as "perfidious," "treacherous," and "blood-thirsty" to

\footnotetext{
${ }^{48}$ Nowell, Abraham in Arms, 10.

${ }^{49}$ John Richardson, The Necessity of a Well Experienced Souldiery: Or, A Christian Common Wealth ought to be well Instructed \& Experienced in the Military Art. (Cambridge, 1679, 1.

${ }^{50}$ Ibid., 3.
} 
describe the "Heathen" attack against them. Wheeler claimed that "they did roar against us like so many wild Bulls" when describing the position of the English within the home where they were garrisoned. Filtered through puritan symbolism, the fires Indians set to Brookfield in efforts to burn the town drew implicit connections to demonic hellfire and biblical attacks by heathens against Israel. After the Brookfield garrison escaped, Wheeler rejoiced that God "kept us from being all a prey to their Teeth. ${ }^{51}$ In his history of the war, Increase Mather drew on similar language to describe the colony's enemies, calling them "barbarous Creatures," and further described them as "sunk down into the pit that they made" once the tide of the war had turned, musing that nobody "knoweth how cruelly a dying Beast may bite before his expiration?."52 Most clearly, in a description of Indian torture methods which included a naked run through a gauntlet of tormentors, Mather wrote: "whipping them after a cruel and bloudy manner, and then [they] threw hot ashes upon them; cut out the flesh of their legs, and put fire into their wounds, delighting to see the miserable torments of wretched creatures. Thus are they the perfect children of the Devill. ${ }^{, 53}$ Clergyman William Hubbard's narrative of the war gave even greater prominence to the Devil, as he wrote: "in the year 1671 the Devill, who was a Murderer from the beginning, had so filled the heart of this salvage Miscreant [Phillip] with envy and malice against the English, that he was ready to break out into open war against the Inhabitants of Plimouth." ${ }^{\circ 4}$ Colonists drew lines to connect the Devil and Indians in their earliest encounters, but the realities

\footnotetext{
${ }^{51}$ Wheeler, A Thankfull Remembrance, ii, 2-3, 6, 12. Amidst descriptions of Indian fire attacks, Wheeler also records an exchange between the Indians and colonists regarding God's protection. While the English loudly declared that God fought with them, the Indians "shouted and scoffed" at the colonists, taunting them further.

${ }^{52}$ Increase Mather, Brief History of the Warr, 10, 60-61.

${ }^{53}$ Ibid., 45.

${ }^{54}$ William Hubbard, A Narrative of the Troubles with the Indians In New-England, from the first planting thereof in the year 1607. to this present year 1677. But chiefly of the late Troubles in the two last years, 1675. and 1676. To which is added a Discourse about the Warre with the Pequods In the year 1637. (Boston, 1677), 11. The rivalry between Mather and Hubbard in penning competing accounts of the war is covered in Lepore, The Name of War, 4852.
} 
of widespread war sharpened this contrast and gave credence to the notion that Indians suffered from demonic possession.

In a much more visceral sense, Mary Rowlandson's 1682 captivity account merged William Hubbard's florid descriptions of indigenous savagery with Increase Mather's efforts to discern religious significance in wartime events and God's will amidst the conflict. ${ }^{55}$ The introduction, thought by many scholars to have been penned by Increase Mather, stressed that readers of Rowlandson's account could not even comprehend being enslaved "to such atheistical, proud, wild, cruel, barbarous, brutish (in one word) diabolicall creatures as these, the worst of the heathen." Amidst graphic imagery of blood running and spilled entrails with the attack on Lancaster by enemy "Infidels," Rowlandson likened the scene to "a company of Sheep torn by Wolves. All of them stript naked by a company of hell-hounds, roaring, singing, ranting, and insulting." ${ }^{, 56}$ Rowlandson blamed the Lancaster attack on One-eyed John (the Nipmuck sachem Monoco), and the Marlborough Praying Indians, repeating the erroneous charges of Samuel Moseley and William Hubbard. ${ }^{57}$

\footnotetext{
${ }^{55}$ Salisbury, "Introduction," in Sovereignty and Goodness of God, 38-41. Puritan typology also served as a guide for Rowlandson's interpretation of her captivity, as she stated after her sixth remove that "travelling into the vast and howling Wilderness, and I understood something of Lot's Wife's Temptation, when she looked back." (80) Here, as with other moments, Rowlandson drew on Old Testament stories and drew allusions to her similar experiences. ${ }^{56}$ Mary Rowlandson, The Sovereignty and Goodness of God, edited by Neal Salisbury (New York: Bedford/St. Martin's, 1997), 67, 69-70. In their assessment of captivity narratives as literature and history, Vaughan and Clark note that "they served readers a hearty fare of literary and psychological satisfaction, peculiar to their time and place," in assessing the popularity of the growing genre. As a pioneer of the literary form, Rowlandson's narrative offered an intense spiritual autobiography which bolstered the puritan worldview and offered a hint at her sanctification through the metaphor of captivity (to sin) and redemption. Alden T. Vaughan and Edward W. Clark, eds. Puritans Among the Indians: Accounts of Captivity and Redemption 1676-1724 (Cambridge: Belknap Press, 1981), 3-5, 9. Billy J. Stratton makes the most direct case for Increase Mather's role as the author of the introduction and editor to the overall text, noting that his interest in Mary's situation grew when her husband Joseph went to him to help redeem her, which he included in his history of the war. Stratton also argues that the later dissemination of captivity narratives during crucial moments of wartime helped the English band together by reinforcing or amplifying Indian "otherness." Billy J. Stratton, Buried in Shades of Night: Contested Voices, Indian Captivity, and the Legacy of King Philip's War (Tucson: University of Arizona Press, 2013), 20-23, 112-14.

${ }^{57}$ Salisbury makes this point in the footnotes of his edited volume of Rowlandson's captivity. Rowlandson, Sovereignty and Goodness of God, 71.
} 
Rowlandson also reserved special rancor for Praying Indians at various points in her narrative, casting doubt on the notion that they were truly committed to the English and transformed into godly Christians. One Indian Christian threatened her with a blade for her sluggishness during the twelfth remove, but what infuriated Rowlandson was that the man had rejoined the English after the war ended and frequented Boston "under the appearance of a Friend-Indian," along with "severall others of the like Cut." Later, when discussing the negotiations for her redemption she began a lengthy aside railing against Praying Indians for writing the letters for the Indian side of the correspondence, and for other signs of the fragile or facetious nature of their Christianity. She described another Praying Indian who argued with his brother over the merits of eating horse meat, noting that he used the verse of 2 Kings 6:25 and "shewed him that it was lawfull to eat that in a Famine," which convinced the brother to give up his scruples and "eat horse with any Indian of them all." Rowlandson blamed another for betraying his father in order to gain a pardon after committing atrocities against the English, and balked at another Praying Indian "so wicked and cruel, as to wear a string about his neck, strung with Christians fingers." Finally, she observed a ritual ceremony with voyeuristic fascination as Indian Christians joined with their allies and powwows to prepare themselves for war. To Rowlandson, "they acted as if the Devil had told them that they should gain the victory," but after their defeat they returned with painted faces "as black as the Devil." 58 Though Rowlandson expressed appreciation and thanks for the occasional kindness shown to her by Indians, she frequently attributed the behavior of enemy Indians to God's providence rather than their own action, and failed to mention that Tom and Peter, who negotiated for her redemption, were Indian

\footnotetext{
${ }^{58}$ Ibid., 87, 97-101. The Indian scribe was most likely James Printer, who managed to ingratiate himself with the English once they extended an offer for pardon to any Indian who had not killed Englishmen during the war.
} 
Christian allies who faced substantial risk as intermediaries between Philip and the English. ${ }^{59}$ Ignoring the complexities of the factionalism which rent native communities both independent and Christian, Rowlandson fixated on the notion of Praying Indian defection and offered a powerful indictment of their behavior during King Philip's War.

The theological ramifications of this polemic for both enemy Indians and Praying Indian allies played a tremendous role in the treatment of Praying Indians and captured enemies during the course of the war. When English parishioners listened to or read colonial sermons about the nature of their souls, minds surely wandered to reflect on the state of enemies whom they increasingly viewed as devilishly barbaric. In his sermon on the necessity of spiritual soldiery, Samuel Willard reminded his audience that a soul left untouched by God remained "a Lump of unserviceable matter, a meer piece of Corruption." Indeed, if every man and woman soldiered under Christ or the Devil in this cosmic war, then enemy Indians remained enslaved to the unredeemed and corrupting nature of their $\sin .{ }^{60}$ When Samuel Hooker described wicked men as "foolish and simple, vile, and loathsome," this likely reinforced colonial opinions about Indians. Similarly, when he stated that the people rejoice under righteous authority, "but when the wicked beareth rule, the people mourn," colonists could reflect on the trauma and loss that came with Philip's reign during the early war. ${ }^{61}$ While ministers intended these ideas for the purpose of selfreflection in their parishioners, the reflexive nature of puritan theology ensured that colonists

\footnotetext{
${ }^{59}$ Ibid., 97, 102-108. In her examination of Indian uses of literacy and acculturation, Hilary E. Wyss writes of the war and the failure of missionary efforts to "civilize" Indians: "For Rowlandson and others like her whose attitudes were molded by the war, Natives could dress like the English and even act like the English, but they could never truly be English, or Christian." Hilary E. Wyss, Writing Indians: Literacy, Christianity, and Native Community in Early America (Amherst: University of Massachusetts Press, 2000), 12-13, 50.

${ }^{60}$ Willard, The Heart Garrisoned, 4-6. Furthermore, the rhetoric of Indian conversion also aided an interpretation in this vein, as John Eliot and Roger Williams both emphasized the remnants of civilized Jewish culture within Native American societies. If the telos of missionary activity was to effect conversion and a restoration to civilized status, it created what Matthew P. Brown terms a "relic quality of the Indian past" that further emphasized their current deficiencies by English standards. Brown, Pilgrim and the Bee, 186-93.

${ }^{61}$ Hooker, Righteousness Rained from Heaven, 9.
} 
could just as easily position themselves as righteous, and the Indians as wicked. A forsaken condition, is the condition of the Offspring of Abraham," according to Joseph Rowlandson, which could easily be ascribed to Indians in light of the progress of war and debates regarding their origins on the continent. Such a state was the harshest punishment God could bestow upon a people. In his 1678 sermon, Rowlandson raised the rhetorical question regarding the difference between "a sinner forsaken and a Saint forsaken," concluding that the Saint pursued God until he returned to him, but the sinner was "left in darkness." 62 Colonists in 1678 could reflect on their victory and conclude that the destruction of their enemies validated their status as forsaken barbarians, forever cut off from God's salvific grace. They could also consider Caribbean enslavement a just punishment for enemies of this nature.

Puritan theology applied to Indians during King Philip's War also explains the growing hostility towards Praying Indians during the course of the war. If Indians were increasingly viewed as typological barbarians acting out the plans of God or the Devil across a Canaanite template applied to New England, and if their behavior served to validate puritan notions of the unregenerate soul, then what of Praying Indians: people who adopted many markers of English culture and religion? What of the long struggle to institute a covenanted Indian church, and their expressions of fidelity during the early war? Puritanism's antagonistic relationship with Catholicism and the Anglican Church offered a collection of theological concepts related to good works, the regeneration of the heart, and predestination which ministers could apply to Praying Indians in order to invalidate the identity crafted by them, in cooperation with Eliot, over the previous decades. Samuel Willard wrote that "Satan is willing men should do, and take pains in doing outward Services, he suffers them to read, hear, pray, give Alms, \&c. they may go as farr

\footnotetext{
${ }^{62}$ Joseph Rowlandson, The Possibility of Gods Forsaking a people, That have been visibly near \& dear to him... Set forth in a Sermon, Preached at Weathersfield, Nov. 21. 1678. (Cambridge: 1682), 7, 10-11, 15-16.
} 
as they will in bodily Service, only let him have the Homage of their hearts." ${ }^{63}$ The puritan

concern for outward behavior without inward regeneration was a common theological point, as

Thomas Thatcher reminded his audience:

You may be outwardly a Christian, and inwardly an heathen in the sight of God, all these are uncircumcised in heart says the Prophet, when he reckons up the Nations together with Judah, you may be a Heathen in heart, whilest you are in the outward man a Christian, your Circumcision may become uncircumcision before God; alas what's an outward Baptisme, if your Souls never reach after spiritual Baptisme. ${ }^{64}$

When a number of Nipmuc chose to side with Philip against the colonists, attacking them at

Brookfield and other battles, this validated colonial sentiments that Indians kept up outward appearances without any real inward attachment to the colonists. A raid on the town of Nashaway, which was near the Nipmuc Praying Towns, convinced many that their Indian allies were secretly in league with the rest of the Nipmuc. ${ }^{65}$ Furthermore, the capture of Nipmuc men and women from the "new" Praying Towns generated a spate of rumors that they had willingly defected to the enemy's side, convincing many colonists that Indian affiliation with Christianity remained an outward sham rather than an inward transformation, despite the claims of Eliot, Gookin, and supporters of the missionary endeavor. As homes, crops, and haystacks mysteriously caught fire in the night in Chelmsford and Dedham, colonists assumed their

\footnotetext{
${ }^{63}$ Willard, The Heart Garrisoned, 5.

${ }^{64}$ Thatcher, A Fast of God's chusing, 20. Thatcher continues with "there are many mock-services whereby mockChristians mock God in their profession," again reiterating the common notion that the elect remained a small body, with many others who remained outwardly faithful without inward regeneration.

${ }^{65}$ Mandell, King Philip's War, 82. Utilizing the Massachusetts colonial seal as a barometer for colonial anxieties, Cathy Rex offers the most penetrating analysis of James Printer's defection to Philip's cause and his redemption, arguing that "Printer became the stark realization of just how loosely the ties of colonization bound those under its thrall." Cathy Rex, "Indians and Images: The Massachusetts Bay Colony Seal, James Printer, and the Anxiety of Colonial Identity," American Quarterly 1 (2011): 77-87. Indeed, the fact that Praying Indian communities divided over the reality of divisive warfare and defected or fled hampered Gookin's later efforts to cast Indians as martyrs within Doings and Sufferings. J. Patrick Cesarini argues further that this effort to balance a providential understanding of historical action in the war with rational analysis of the difficulties Praying Indians faced served to undermine Gookin's narrative as a standard Puritan history. J. Patrick Cesarini, "What Has Become of Your Praying to God?" Daniel Gookin's Troubled History of King Philip's War," Early American Literature 44 (2009): 496-98.
} 
Praying Indian neighbors were responsible, or engineered these incidents to displace them by capitalizing on public mistrust of all Indians within the colony. ${ }^{66}$ This culminated in the confinement of some two hundred Natick Indians, ostensibly for their protection, on the cold and wind-swept Deer Island in the Boston harbor where they faced a bleak and ill-supplied winter digging for clams and shellfish on the cold shore during low tides. ${ }^{67}$

Regardless of the particular interpretation of Indian actions or roles within the cosmological drama playing out in New England, this theological construction served to diminish Indians in the sight of many colonists, reducing them to the status of mere animals: unthinking, brutish, and savage. Permanently cut off from God, puritans conceptually reduced enemy Indians to the fate of pawns in a biblical drama reenacted in a North American setting. The culmination of this vein of thinking, along with its corresponding theological implications, is found in a series of quotations from Nowell's sermon Abraham in Arms. Nowell suggests at one point that Israel bested its Canaanite enemies with the help of miraculous intervention, yet in the puritans' time God ceased to intervene in that way, so God must consider the puritans able in their martial capacity to defeat their colonial enemies, otherwise he would not challenge them in this way. Nowell then utters the most starkly exclusionary statements about the fate of Indians within the colony, grounding them in typological barbarism and puritan theology: "The inhabitants of the land will not joyn or mix with us to make one Body, which is the more likely they are preserved to be thorns in our sides." Nowell justified this exclusion by drawing on the

\footnotetext{
${ }^{66}$ Gookin, Doings and Sufferings, 463, 475-77, 483, 492.

${ }^{67}$ Mandell, King Philip's War, 83-85. The initial Natick refugees were later joined by the Nashobas when they were confined, raising the population to about 550. As a point of contrast, Jason W. Warren explores the critical role that Indian allies played for Connecticut during King Philip's War, arguing that they balanced a pragmatic reliance on indigenous methods of negotiation and tribute offerings with the deterrent of military force. The colony notably learned its lesson during the Pequot War of the 1630s, which led them to adopt measures such as integrating Indians into garrison defense for local towns (a measure Gookin stressed he had proposed to the Massachusetts legislature in Doings and Sufferings, but was defeated). Jason W. Warren, Connecticut Unscathed: Victory in the Great Narragansett War, 1675-1676 (Norman: University of Oklahoma Press, 2014), 6-10, 78-89, 92.
} 
example of Hamor and Shechem - Canaanite tribes who sought to make peace with biblical patriarch Jacob by marrying his daughters only to be tricked and slaughtered - to harangue the French for their policy of marrying Indian women. Eschewing this tactic as a means to ruin, Nowell argued instead:

When God intended the Canaanites to be destroyed, he did forbid Israel to marry with them: they were to be thorns to them, and Israel was to root them out in the conclusion: therefore frequent trouble, we may probably and rationally reckon of, to meet with from the heathen. Two Nations in are the womb and will be striving. ${ }^{68}$

By reliving biblical history, Nowell suggests that God has given the puritans a unique opportunity to conduct their own Canaanite conquest correctly, sparing no barbarian and maintaining a strict policy of sexual and marital separation. By following this biblical template, puritans could honor their covenant with God and properly carry out their true mission: the creation of a new Israel devoid of Indian barbarians. The importance of this rhetoric cannot be overstated, for it formed the foundation of a policy of greater marginalization of Indians within English spaces after the war.

Coupled with the puritan tendency to distrust outward signs as baseless and sinful without inward transformation by God's spirit, these theological developments overrode Praying Indian claims to a shared Christianity and membership within the same ecclesiastical polity. This shifting theological ground, which had created unique opportunities for Indians to regroup and reorganize their communities in the wake of profound upheavals, could also prove devastatingly exclusionary under tense wartime conditions despite the meaningful religious ideas and rituals Indian Christians found attractive. In the face of mounting hostility and violence, Praying Indians found themselves with few direct allies and even fewer casual supporters as many colonists sided against them as fears and rumors overrode any other concern. Confronted with these challenges,

\footnotetext{
${ }^{68}$ Nowell, Abraham in Arms, 10, 14.
} 
Praying Indians faced difficult choices. Some apparently sided against the colonists, others fled and took their chances far from the theater of war, and still others stayed in an effort to prove themselves yet again. Missionaries and those most directly involved in the project remained the most adamant supporters of the Praying Indians, which nearly cost them their lives when colonists turned particularly bloodthirsty in their desire to punish nearby Indians. In spite of this theological invective, Praying Indians and their supporters attempted to counter this harsh conceptualization with material and theological defenses during the war and in its aftermath.

\section{Defending Praying Indians and Expressions of Fidelity}

The most explicit account of the trials and dangers faced by Praying Indians over the course of King Philip's War is Daniel Gookin's Historical Account of the Doings and Sufferings of the Christian Indians in New England in the Years 1675-1677, which remained unpublished in Gookin's lifetime but represents the only comprehensive history of the war from the perspective of the Praying Indians and defense of their status as Indian Christians in the face of this theological assault on Indians across the colony. Ministers like Increase Mather maintained a view of Praying Indians which vacillated between contention and approval, as he wrote in his Brief History of the Warr that "The Praying Indians did good Service at that time, insomuch as many who had hard thoughts of them all, being to blame themselves, and to have a good opinion of those Praying Indians who have been so universally decried," yet in his Historical Discourse Concerning the Prevalency of Prayer (1677), he wrote that the Natick and Punkapoag Indians "do pretend friendship to the English," suggesting that they masked their loyalty with deceit. ${ }^{69}$ In picking up his pen to chronicle the trials of the Praying Indians during the war, Gookin sought to

\footnotetext{
${ }^{69}$ Mather, Brief History of the Warr, 47; Increase Mather, An Historical Discourse Concerning the Prevalency of Prayer Wherein is shewed that New-Englands late Deliverance from the Rage of the Heathen, is an eminent Answer of Prayer. (Boston, 1677), 5.
} 
correct the slights contemporary histories of the war gave to their service and importance as spies and soldiers. ${ }^{70}$ At the same time, his emphasis on the "sufferings" of the Praying Indians casts them within the vein of early modern martyrologies in an effort to defend their piety and the validity of their conversions to Christianity in the face of missionary detractors. Gookin's use of martyrdom as a constant theme within his narrative renders Doings and Sufferings a decidedly religious response to the growing theological invective against Praying Indians.

The templates of martyrdom provided by John Foxe in his 1554 Acts and Monuments (first printed in English in 1563) and the subsequent revisions and derivative anthologies produced from Foxe's work, like Timothy Bright's 1589 abridgement or Clement Cotton's similar revision of 1613 entitled Mirror of Martyrs, served to narrate the persecution of Christ's true church by corrupted religious officials in the Marian church. Anne G. Myles writes that of its many functions, the stories in Foxe's work helped readers "confront the central issue of how believers might know they were among the elect 'by modeling how answers might be found at moments of persecutory crisis." "71 Thus, persecution at the hands of corrupted authorities

\footnotetext{
${ }^{70}$ Cesarini, "What Has Become of Your Praying to God?," 491-92. Cesarini suggests that the challenge to understanding Gookin's history lies in his efforts to bridge the gap between new empiricist modes of explanation and the providentialist epistemology of the Puritans. I argue that the emphasis on suffering coincides with early modern martyrologies which remained a popular means of demonstrating the piety and surety of faith which remained elusive in light of the doctrine of predestination within Calvinist theology.

${ }^{71}$ Anne G. Myles, "Restoration Declensions, Divine Consolations: The Work of John Foxe in 1664 Massachusetts," The New England Quarterly 80 (2007): 59-60. The legacy of Foxe's template of "heroic mortification" is also explored in the context of "epic religion" and providential suffering in Reid Barbour, "The Caroline Church Heroic: The Reconstruction of Epic Religion in Three Seventeenth-Century Communities," Renaissance Quarterly 50 (1997): 787-95. In thinking about the power of martyrdom in Christian rhetoric, I found Simon Ditchfield's article on pious thought in the early modern period to be particularly enlightening, albeit from a Catholic perspective. Ditchfield's description of Catholic caution in sanctifying individuals in the wake of Protestant critique suggests a similar challenge of empiricist versus providential epistemologies highlighted by Cesarini above. Simon Ditchfield, "Thinking with Saints: Sanctity and Society in the Early Modern World," Critical Inquiry 35 (2009): 567. Though Protestants abandoned the veneration of saints beyond the early Apostles, they created their own demi-saints through the emphasis on the martyr's suffering in the face of persecution formulated by Foxe and promulgated throughout the expanding Protestant world. Brad S. Gregory observes that recanting in martyrdom often came with a negative stigma, as "only unreflective, dimwitted, or doctrinally uncertain people would jeopardize their souls through a principled rejection" of faith, which Gookin grappled with in his own work, though the genre served as a powerful means of demonstrating piety through suffering. That said, martyrology was often a contested form of literature, as European sectarianism created environments where "controversialists attacked those whom fellow
} 
became a standard trope within Protestant martyrologies, which also highlighted the exemplary behavior of true Christians in the face of terrible persecution.

This presented a challenge for Gookin, who was an elected magistrate and Superintendent over the Indian missions himself, as he sought to give "right information how these Christian natives have demeaned themselves in this hour of tribulation." He cautiously leaned on a providential interpretation of the actions of the colony's magistrates when he stated "the most holy and righteous God hath overruled all counsels and affairs in this and other things related to this war," for "the purging and trying the faith and patience of the Godly English and Christian Indians, certainly was another end God aimed at in this chastisement" among other purposes. ${ }^{72}$ As he laid out numerous moments where Praying Indian fidelity was met with English rejection, such as the seizure of weapons from the Indian Christians near Marlborough who helped defend the garrison there and served as scouts in the nearby woods, Gookin could only rely on providential interpretations of this madness rather than a scathing indictment of magistrates whom he generally held in high regard, as "God hid this benefit from the English, which should have been answered and requited with love and thankfulness; but, instead thereof, their neighbours, and hated them, and took counsel to disoblige them." Though Gookin imagined magistrates to be under divine befuddlement in their decision-making during the war, he frequently diagnosed commoners as suffering from more demonic influence: "but 'tis no strange thing for men's reason to be darkened, if not almost lost, when the mists of passion and temptation do prevail.".73 One of the common refrains throughout Gookin's account of the

believers celebrated. The phenomenon was persistent, widespread, and, in the context of religious controversy, inseparable from martyrdom." Brad S. Gregory, Salvation at Stake: Christian Martyrdom in Early Modern Europe (Cambridge: Harvard University Press, 1999), 108-09, 124, 315-16.

${ }^{72}$ Gookin, Doings and Sufferings, 433, 437-38.

${ }^{73}$ Ibid., 460, 470. Cesarini suggests that this effort to balance providentialism with a rational assessment of puritan failings undermined his narrative as he attempted to account for both Praying Indian fidelity and the fact that many 
Praying Indians during King Philip's War is that of continued English mistrust and injustice after numerous instances where Indian allies proved to be loyal and sacrificial in their service to the colony.

The theme of sacrificial service pervades Gookin's account in order to strengthen the claim that Praying Indians were loyal to both their newfound religion and the colony at large. ${ }^{74}$ At a battle near Mount Hope, John Hunter, Thomas Quannapohitt, and Felix returned word to Gookin that Job Nesutan died in the conflict, which Gookin lamented in his text, for Nesutan "was a very good linguist in the English tongue, and was Mr. Eliot's assistant and interpreter in his translations of the Bible, and other books of the Indian language. The loss of such a useful and trusty man was great in the forementioned respects." Continuing his narrative, Gookin also described a firearms accident that wounded eighty-six year old Thomas Runnymarsh in his right arm and rendered it useless. Despite this injury, "this fellow since that time hath done very good service as well as before" for the colony. ${ }^{75}$ In describing the reduction of the Praying Indians to Natick, Punkapoag, Nashobah, Wamesit, and Hassanamesit - the first step taken before their removal to Deer Island - Gookin writes that the Indians "were reduced to great sufferings, being hindered from their hunting and looking after their cattle, swine, and getting in their corn, or laboring among the English to get clothes, and many other ways incommoded," highlighting

Indians - forced or not - abandoned the mission towns and joined the colony's enemies. Cesarini, "What Has Become of Your Praying to God?," 508.

${ }^{74}$ David J. Silverman notes that the Wampanoag community on Martha's Vineyard managed to avoid much of the tragedy the mainland Indians suffered partly because of their geographic isolation on the island and also because they developed a magistrate system where English overseers gave input to Wampanoag governance in 1671 which helped to stem the tide of war. While giving the English an early form of power which enabled them to push for greater subjugation, the imbalance of Indian-English populations (in favor of the island Wampanoag) prevented the English from lashing out as they did on the mainland. At the same time, the development of Wampanoag militia patrols helped defray English suspicions. David J. Silverman, Faith and Boundaries: Colonists, Christianity, and Community among the Wampanoag Indians of Martha's Vineyard, 1600-1871 (Cambridge: Cambridge University Press, 2005), 81-120.

${ }^{75}$ Gookin, Doings and Sufferings, 444-45. 
again their sufferings, which were amplified by the threat of death or imprisonment if they were found outside of the communities. ${ }^{76}$

Gookin also relied on biblical examples to challenge the growing emphasis on typological barbarity that colored all Indians - including those who prayed - as heathens. According to Gookin this invective against all Indians reached a fever pitch, and "the animosity and rage of the common people increased against them, that the very name of a praying Indian was spoken against," leading some "wise and principal men" to advise Gookin and Eliot to "forbear giving that epithet of praying." Presumably the notion of Indian Christians clashed so greatly with the wartime typology to create this rage-filled dissonance. ${ }^{77}$ Further on in his account of the war, Gookin chastised colonists for conflating the Springfield and Northampton Indians with the Praying Indians, for he argued that "not one of them that ever I heard of, that was a pretender to Christian religion." Despite the fact that they were friendly before the war, if unchurched, "their defection at this time had a tendency to exasperate the English against all Indians, that they would admit no distinction between one Indian and another.” Gookin considered this ludicrous and asserted that the colonists erred in "forgetting that the Scriptures do record that sundry of the heathen in Israel's time, being proselyted to the Church, proved very faithful and worthy men and women," listing biblical figures such as Uriah the Hittite, Zeleg the Ammonite, Ithmah the Moabite, Rahab (a prostitute), and Ruth (also from Moab), along with "divers others, men and women." He continued to lament that "wicked men, yea, sometimes godly men, are angry and displeased with others that fear God, and too readily pass judgment on them that they are hypocrites and naught."78 Similarly, in the conclusion of his text Gookin hoped that his readers would receive this work in the vein of "the historical books of Scripture,

\footnotetext{
76 Ibid., 451.

${ }^{77}$ Ibid., 449.

78 Ibid., 454.
} 
as other histories of the primitive times of Christianity, and of the doings and sufferings of the poor saints of God." He concluded that the Indians described in his work were "through the grace of Christ, the first professors, confessors, if I may not say martyrs, of the Christian religion among the poor Indians in America." ${ }^{~} 79$ Clearly casting these Indians as martyrs in an effort to recover biblical typologies and reassert the old identify of Praying Indians, Gookin hoped that this description of their travails during wartime would convince the wider colony to attempt some form of redress for their behavior during King Philip's War and to recognize their Indian neighbors as fellow brothers and sisters in the Christian religion.

Despite the numerous injustices meted out to the Praying Indians, their continuing loyalty and service to the colony did serve to impress or convert many Indian-haters and soldiers initially suspicious of them. As the war unfolded, English soldiers and magistrates recognized the importance of their Praying Indian allies in serving as scouts, spies, guides, and fellow soldiers, giving them a pivotal role in the conflict, which Gookin could capitalize on in order to validate the prominent role Praying Indians took on during the war. Men like Job Kattenanit and James Quannapohit served at great risk to infiltrate enemy Nipmuck, Quabage, and Wesakam Indians at Menumesse under the guise that they were dissatisfied with the poor conditions at Deer Island and sought to determine if defecting to the group at Menumesse was in the best interest of their community. Gookin highlighted the fact that this intelligence was crucial to the war effort of the colony and that Kattenanit and Quannapohit had learned of an attack to take place in three weeks at Lancaster, the attack which led to Mary Rowlandson's captivity, though Gookin asserted that the colony failed to act on this information at the time. ${ }^{80}$

\footnotetext{
79 Ibid., 523.

${ }^{80}$ Ibid., 486-88.
} 
As the war continued, colonial leaders finally relaxed to the point where they were willing to form a company of Praying Indian soldiers under the command of Samuel Hunting and James Richardson because they "were well acquainted with those Indians." This company consisted of about forty armed Indians who marched with their English commanders from Charlestown up the Merrimack River to Chelmsford, where they would defend a fishing spot to prevent enemies from catching food in the winter. Before the group could reach Chelmsford they received word that enemy Indians had attacked and burned much of Sudbury, forcing the town's residents to flee and send word of the attack. The Praying Indian soldiers undertook a great risk by disguising themselves as enemy Indians by stripping down and painting their faces in order to scout out and engage the enemy. Gookin noted that the care the Praying Indians displayed for the English who lay dead and dying "had the effect to abate much, with many, their former hatred of them." This mattered particularly at Sudbury because many of the villagers "had formerly done much injury to these our Christian friends, whilst they dwelt at Natick," by pilfering their belongings and plundering the abandoned town. In order to empirically validate his account, Gookin included a number of certificates at the end of his narrative from captains who served with Praying Indians and could attest to their wartime conduct and valor, including one from Thomas Wheeler in an effort to revise his account of the Brookfield attack in A Thankfull Remembrance of Gods Mercy by stating that Joseph and Sampson "behaved themselves as honest and stout men."

Despite the tangible efforts Praying Indians undertook in order to demonstrate their loyalty in reliance on their new religious identity and connections with men like Gookin and Eliot, wartime atrocities served to starkly illustrate the level of acceptance they had attained - or

\footnotetext{
${ }^{81}$ Ibid., 509-512, certificates 524-34. The certificate from Wheeler is found on pg. 448 in Gookin's narrative, which Gookin claims to have collected before his Wheeler's death in December 1676.
} 
failed to attain - within mainstream puritan society. Despite the best efforts of their colonial allies, which placed both Eliot and Gookin in serious danger of reprisals from mob violence, they were unable to prevent a series of crushing blows to the communities under their protection. ${ }^{82}$ In addition to their encounters with Captain Mosely described in the introduction to this chapter, a group of passing English soldiers brutally murdered the wives of Andrew Pittimee and Thomas Speene along with another young woman and three children as they gathered berries at Hurtleberry Hill near Waterton Mill. ${ }^{83}$ Beyond pitched moments of violence, Praying Indians faced almost daily jeering and smoldering enmity from many colonists they encountered during the war. It is difficult to determine when exactly this mentality abated as the war came to an end with Philip's death at Mount Hope at the hands of John Alderman, an Indian soldier under the command of Benjamin Church. As Philip's body was desecrated and his head bound for display at Plymouth, Praying Indians could reflect on their wartime experiences and the symbolism found in the macabre treatment of Philip's body: despite their sincere and best efforts to chart a middle ground within the colony through the use of religion, many colonists failed to accept them and possibly never would now that wartime experiences solidified the notion of Indians as Canaanite barbarians within their typological drama in New England. All Indians were alike to many colonists, no matter how much they or their English allies insisted otherwise.

\section{Awaking from a Nightmare: Indian Missions after King Philip's War}

With the end of wartime hostilities, the Praying Indians and their English neighbors faced the daunting task of rebuilding their communities in the wake of widespread destruction and

\footnotetext{
${ }^{82}$ Ibid., 453. Early in Doings and Sufferings Gookin emphasizes the enmity colonists had for missionary allies when he wrote that "many harsh reflections and speeches were uttered against Major Daniel Gookin, and Mr. John Eliot." ${ }^{83}$ Ibid., 513. Praying Indians soldiers continued to serve in the war, particularly in the fighting along the Maine frontier.
} 
displacements. Scholars estimate that the war killed some nine thousand people, with Indians suffering the majority of the casualties. In southern New England depopulation through slaving and wartime deaths pushed Indian populations from about twenty-five percent to around ten percent of the total regional population. ${ }^{84}$ As hostilities died down and the tempers of colonial Englishmen began to cool, missionaries and Praying Indians sought to reevaluate the project and commit themselves to various aims moving forward. At times both groups struggled with despair as they reflected on the events that transpired during the war. At other times they confronted shifting perspectives about Indians and adjusted their expectations and actions accordingly. Still others chose to abandon the project entirely. By the end of the century, Indian Christian communities faced new challenges as they experienced the deaths of their English benefactors and the challenges of transmitting religious faith and culture across a generational gap. In the end, these communities rebuilt and adapted to a new colonial world of solidified English hegemony within small, tightly-knit enclaves such as Natick and Wamesit.

Gookin observed that before the war there were seven places where Indians gathered for church services led by Eliot or Indian ministers at Natick, Nonatum, Punkapoag, Medfield, Concord, and Namkeake, but that Indians had only resettled Natick and Magunkog by the spring of 1677 , and colonial magistrates sought to confine those who were not house servants to a small number of Praying Towns where they faced frequent observation. ${ }^{85}$ Some had attempted to rebuild Hassanamesit but left because they feared Mohawk attacks which continued throughout

\footnotetext{
${ }^{84}$ Mandell, King Philip's War, 134. Julius H. Rubin, Tears of Repentance: Christian Indian Identity and Community in Colonial Southern New England (Lincoln: University of Nebraska Press, 2013), 81. Rubin notes that some 60-80 percent of Wampanoags, Narragansetts, Nipmucks, and Agawams were killed or sold because of their allegiance to Philip, marking their casualties as even more severe.

${ }^{85}$ Leach, Flintlock \& Tomahawk, 245. Lepore notes that Praying Indians continued to live a hybrid blend of English and Indian practices after resettlement in Lepore, The Name of War, 184-85. Mandell observes that the loss of land for many communities laid important groundwork in tying these communities to the regional Anglo-American economy where "they became whalers, domestic servants, and laborers, and the men went to fight for the colonists" in later wars. Mandell, King Philip's War, 119.
} 
the following decades, and others resettled with the English at Medfield, Concord, Cambridge, and Chelmsford, presumably in far reduced numbers. ${ }^{86}$ Even though the cessation of war brought an end to the worst of colonial rancor towards Praying Indians, sporadic acts of violence continued at times, such as an incident at Cowate where a "poor widow woman" was brutally hacked with a hatchet by a Sudbury man named Curtis. Bleeding from numerous gashes to her head, the woman eventually recovered but was unable to identify her attacker. ${ }^{87}$ In reports to the English branch of the CPG in 1678 and 1679, New England's commissioners stressed that recovery continued at a slow pace, but "not without hopes of their returne," for King Philip's War had "greatly vitiated the spirits of our youth both English \& Indian." The commissioners also pushed their English supporters to open their coffers in financial support of a group of fifty Praying Indians who served faithfully in the war as well. ${ }^{88}$

The reaction of colonists and Indians in the war also forced Englishmen on both sides of the Atlantic to reevaluate the priorities and goals of the project, readjusting their expectations in light of the argument of typological barbarism solidified during the war. This argument also colored some aspects of communication regarding the missionary project. For instance, the 1679 commissioners' letter to Boyle referred to their Indian charges as "poor wilde creatures," under the Lord's singular care: an interesting choice of words considering the decades spent at Praying

\footnotetext{
${ }^{86}$ The frequency of Mohawk attacks led Eliot to stress the imperative nature of translating his work into the Mohawk language so as to pacify them and draw them into closer alliance with the English, presumably through a similar missionary project. Ford, ed., Some Correspondence Between the Governors and Treasurers, 79-80. Letters, "John Eliot to Robert Boyle, 23 Aug 1677, 4 Sept 1680, 15 Jan 1683," RB/3/2/83-93, Robert Boyle Papers, The Royal Society Archives, London, United Kingdom.

${ }^{87}$ Gookin, Doings and Sufferings, 518-19. Gookin noted that her attacker was a man named Curtis because he spoke of the incident and claimed self-defense, which Gookin considered highly unlikely. This was not an isolated incident, as Jill Lepore documents an attack by Benjamin Henden against an Indian during peacetime to demonstrate the difficulty of this transition in Lepore, The Name of War, 183.

${ }^{88}$ Ford, ed., Some Correspondence Between the Governors and Treasurers, 59.
} 
Towns meeting and exceeding English expectations regarding civility ${ }^{89}$ In 1679 Charles Chauncy wrote a letter to Boyle on behalf of Harvard College, stressing his devotion to "the eternal welfare of the Barbarians" as the school's second president. In his request for new printing supplies and type for the Cambridge press, Chauncy argued that "there is no more need to issue yet further books from the Press for the use of the Indians," and that new materials were essential so that the press might serve the English colonists to prevent their decline in learning, civil government, and religion. Chauncy's letter is telling in his frank admission that the colonists had worked hard enough to support the missionary project through the printed word, and his use of the term "barbarian" is also telling of his conception of the Praying Indians as a whole. Rather than fellow brothers and sisters in Christian communion who needed access to biblical texts, Chauncy rendered them simple barbarians. This argument proved weighty enough to prompt debate over Eliot's insistence on printing the entirety of the Old Testament in Algonquian, which Eliot appears to have overcome by pressing the New England branch of the company to authorize production before receiving official word from England. ${ }^{90}$

The war also tempered Eliot's expectations regarding the nature and scope of his work among the Indians in what was likely a crushing blow on top of the failure of his millennial expectations in the 1660s. In a letter to Boyle in 1681, Eliot cited Amos 5:13 and the prophet's decision to "keepe silence in yt time, for it is an evel time. for my owne pt I keepe off from medling in those matters, there is a time to be silent $\&$ a time to speak." ${ }^{.11}$ Does Eliot mean to keep silent when it comes to prophecy, or is this a statement on the wider failing to integrate

\footnotetext{
${ }^{89}$ Ibid., 59. While the Eliot Tracts and correspondence before the war stressed the Indians' "heathenish ways" at times, they also paint a picture of progress in their movement towards religious conversion and the establishment of an indigenous church. I argue that this choice of words by the commissioners in New England is significant because it flies in the face of the previous decades and their refrain of progress and represents a movement away from earlier thinking regarding Praying Indians and their place within the colony.

${ }^{90}$ Ibid., 64-65, 70-72

${ }^{91}$ Ibid., 66.
} 
Indians and Englishmen in Christian communion? For his part, Eliot shifted his efforts to focus primarily on his literary projects, working to complete the Old Testament, revise some of his earlier translations, and print new editions of The Practice of Piety and his Indian Primer. ${ }^{92}$ In a 1683 letter to Boyle, Eliot stressed the good nature of their combined literary endeavors, and urged Boyle "to change the object of your bountyfull charity, from theire bodys to theire soules" as a fitting new direction, given his progress in translation. ${ }^{93}$ Eliot also came to embrace the notion put forward by his English benefactors that Indians should learn English as a further means of cultural conversion, which Eliot had previously eschewed in favor of Algonquian. Thus, sermons conducted by English ministers and court proceedings overseen by Gookin moved to English in order to force Indians to adopt the language. In the final letters he sent to Boyle and the English company, his bitterness often bled through into his correspondence, as he

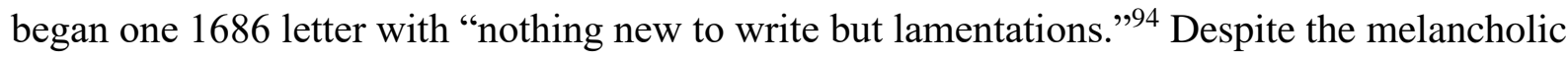
tone he frequently took within correspondence at the end of his life, and the shift in his primary focus to leaving a literary legacy for the Indian communities to which he devoted so much time and effort, Eliot continued to prove an important ally in Indian efforts to rebuild and strengthen their own communities.

In 1684 Eliot delivered his final direct assessment of the state of the Indian churches under his supervision to Robert Boyle, which provides a window into the role of the indigenous church within their communities. Eliot stressed that they kept the Sabbath at the four Praying Towns and at seasonal hunting, fishing, and foraging places. Piety varied within the

\footnotetext{
${ }^{92}$ Ford, ed., Some Correspondence Between the Governors and Treasurers, 68. Letters, "John Eliot to Robert Boyle, 4 Sept 1680, 27 Sept 1683, 7 May 1688," RB/3/2/83-93, Robert Boyle Papers, The Royal Society Archives, London, United Kingdom.

${ }^{93}$ Letter, "John Eliot to Robert Boyle, 27 April 1683," RB/3/2/83-93, Robert Boyle Papers, The Royal Society Archives, London, United Kingdom.

${ }^{94}$ Letter, "John Eliot to Robert Boyle, 29 June 1686," RB/3/2/83-93, Robert Boyle Papers, The Royal Society Archives, London, United Kingdom.
} 
communities, as Eliot wrote that "some of the vain \& carnal sort among them, are not so girt to it, as were to be desired, yet the grave \& religious sorts do constantly worship God every Sabbath day." Eliot also distinguished between "publick Assemblies" and gathered churches where Indians chose their own officers and preachers, for only in churches that owned the covenant could the Lord's Supper be instituted. Daniel Gookin, Jr., the thirty-three year old son of the major, delivered a sermon in English at Natick once a month for the Indians and residents of Sherborn with the aid of an interpreter. Eliot believed this would aid the Indians in learning English and Gookin in learning Algonquian, "which is a point of wisdom in civiliseing them." He concluded the letter with a report that there were twenty other gatherings between Plymouth and Martha's Vineyard, attributing the dispersal of these gatherings to the difficulty in finding parcels of good land. In the end, he concluded that the Indian churches were able "to practise \& manage the whole instituted publick worship of God among themselves, without the presence or inspection of any English among them," stressing again to Boyle that he believed them to be true Christians and independent in church governance. In a postscript to this letter, Eliot related to Boyle that some friends of the Indians in Sherborn had helped them compose a letter to Eliot, which he thought right to include in his correspondence to Boyle, which sheds a bit of light on Indian aims during this period.

The Natick Indians began their letter by reminding Eliot that he was their "spiritual father" and had done much to help them throughout the years, though they were sad that his visits became much more infrequent due to his age. Recognizing the importance of the coming transition when Eliot was to pass, the Natick Indians had apparently solicited Gookin, Jr. in neighboring Sherborn to come and deliver sermons to them in an effort to forge a close

\footnotetext{
${ }^{95}$ Letter, “John Eliot to Robert Boyle, 22 Feb 1684," RB/3/2/83-93, Robert Boyle Papers, The Royal Society Archives, London, United Kingdom.
} 
relationship with the rising generation of English ministers. That the sermons were delivered in English presented a bit of a problem, for "al doe not fully understand, but some learn a litle and desire to know more of it." The Indians also defended their use of an interpreter, who met with Gookin the day before the Sabbath to discuss the topic of the sermon to better translate, citing 1 Corinthians 14:27-28 in recognition of similar practices "in the primitive times." ${ }^{\text {"96 }}$ The Indians also expressed their pleasure in building a mixed congregation with Englishmen as a result of Gookin's visits, for the English "by their example \& communion with us in the worship of God it tendeth (as is evident) to promote not only Religion but Civility amongst us." Whether or not these exact words came from Waban, Daniel Takawompait, John Moquah, and the remaining signatories, the desire to push for a closer communion with their English neighbors sheds light on an Indian response in the wake of King Philip's War. The letter urged the commissioners to secure Gookin's work with Natick, despite the linguistic barriers between him and the congregation, "because now the English Christians, are present and Communicate with us in God's Worship, which puts a great luster and beauty upon our meeting, and tendeth to instruct us especially young ones to learn the English Language." 97

As a measure of adaptation, the Natick community apparently decided to place a greater emphasis on learning English, especially with their children, and building a religious rapport with neighboring Sherborn through the institution of regular sermons by the younger Gookin. That they recognized the importance of securing funding from the English Corporation for the Propagation of the Gospel suggests an understanding of the transatlantic nature of English mission work and the importance of Eliot in securing this funding. Such efforts by Natick and the other communities became increasingly necessary as age caught up to their English allies.

\footnotetext{
${ }^{96}$ Ford, ed., Some Correspondence Between the Governors and Treasurers, 74-75.

${ }^{97}$ Ibid., 75.
} 
Thomas Mayhew died in 1682, causing Eliot to worry that "there will be one wanting to have the Oversight" in Martha's Vineyard. Daniel Gookin died in 1687, leaving behind his wife Mary, and John Eliot followed shortly thereafter in 1690. The 1680s brought other significant transitions, as longstanding Indian leaders like Waban died (c. 1685), and Robert Boyle stepped down as chair of the English corporation in 1689 due to health concerns. ${ }^{98}$ As the eighteenth century began, Praying Indians faced new challenges to their leadership and religious direction in the wake of the tumult that formed the last quarter-century.

\section{The Perils of War}

War is a damaging and complicated affair for those forced to endure it, and King Philip's War in particular placed Indians and Englishmen in difficult positions as they navigated frontier violence, understandings of the war's cause and purpose, and a proper sense of who were allies and enemies. Despite the widespread destruction of the war, the English quickly rebuilt and expanded their settlements in the vacuum created by Indian destruction, enslavement, and dislocation, which significantly reduced the overall Indian population on the mainland and tipped the scales of hegemony decidedly in favor of the English. ${ }^{99}$ The war also served as a template for future wars against Indians and laid the groundwork for a rhetoric of racialized difference between Englishmen and Indians - deemed natural, indelible, and permanent by proponents of this viewpoint. Supporters of this new portrayal of Indians as abject barbarians or pawns permanently ensnared by the Devil relied on Old Testament typologies as a master narrative for

\footnotetext{
${ }^{98}$ Ibid., 68. Letter, “John Eliot to Robert Boyle, 7 May 1688,” RB/3/2/83-93, Robert Boyle Papers, The Royal Society Archives, London, United Kingdom. Letter, "Robert Boyle to the Corporation for the Propagation of the Gospel, 22 Aug 1689," RB/3/1/69, Robert Boyle Papers, The Royal Society Archives, London, United Kingdom. ${ }^{99}$ Mandell, King Philip's War, 134. Leach, Flintlock \& Tomahawk, 246. Leach contends that New England before 1675 was a bold, self-assured, and youthful society, and that the war served as a fulcrum for change which pushed the colony into maturation and tempered the old dream of a "true wilderness Zion." If colonists could rejoice in the removal of Indian enemies, they turned in later decades to the Crown's growing focus on overseas colonies and their governance, along with competing French interests north of New England in places like Acadia. See pages 249-50.
} 
the parts they were to play. Indians served their purpose as Canaanites in a New World context, where God had placed them as a test to English mettle. The English could succeed where the Israelites failed by enslaving or totally destroying their barbarian enemies, establishing a true New Jerusalem in the colony. When ministers like Increase Mather attempted to reinject a divine understanding of the war in response to the more material concerns of men like Hubbard, they provided a theological justification for Indian-hating, violence, and enslavement.

This religious argument proved dangerous for Praying Indians, who lived peacefully with the English for decades and worked diligently to attain sufficient understandings of Protestant theology to establish covenanted churches as a measure of religious parity with their neighbors. Despite their best efforts to form hybridized societies to cope with the darker aspects of colonization and disease epidemics, the growing wartime biblical rhetoric threatened to engulf them and nullify their achievements by castigating their piety as popish works, and Indian souls as unregenerate. It certainly did not help the case of Praying Indians that some chose to take their chances on their own or with the attacking Indians, solidifying the notion that Indian Christians were not true Christians in the minds of many Englishmen. The horrors of wartime dislocation, internment on Deer Island, murders, and general hostilities demeaned and demoralized many of the Praying Indians. In the decades that followed King Philip's War, these communities faced difficult decisions as they struggled to rebuild and achieve a degree of normalcy within the colony. It comes as no surprise that some turned to alcohol and that full covenant membership within the Indian churches declined during this period. Why bother attaining parity with the English when they categorically refused to extend recognition of a shared humanity? In the end, this chapter traces an important aspect of religious history and theology as a component of cultural history by demonstrating the mechanisms for exclusion and mistreatment forged in the 
context of wartime mistrust. This invective against Indians proved exportable to other contexts and conflicts, and served as an important groundwork for new racialized understandings that rose to prominence in the eighteenth century. Indeed, biblical typology provided a template for Indian exclusion, which New England puritans readily applied in their day as a teleological framework for understanding the context of the colonial experience and the place of Indians. Concretely established, it became a powerful force which Indian Christians continually grappled with throughout the eighteenth century. 


\section{Chapter Five Open Tables and Closed Communities: Stoddardeanism, Indian Revivals, and the Corresponding Antirevivalist Critique, 1700-1750}

David Brainerd shook with terror as he beheld a Delaware powwow dressed up in "his pontifical garb" of bear skins and a wooden face painted black and red. Keeping time on a tortoise shell rattle filled with corn, the man danced and sang as he advanced up into Brainerd's face and retreated, in a display that was "so prodigiously frightful" to the observing missionary. Brainerd later had the opportunity to speak with the powwow candidly - puritan minister to Indian powwow - and found that the two held much in common. The powwow told Brainerd that the "very degenerate and corrupt" behavior of his kinsmen disgusted him, deploring the drunkenness that wracked his community. Sometime around 1740 or 1741 he moved to a solitary part of the woods and underwent spiritual regeneration, emerging as a strong advocate for a new form of Indian religion nonetheless informed by aspects of Christianity. Brainerd observed that "it was manifest he had a set of religious notions that he had looked into for himself, and not taken upon bare tradition," and that he relished the religious exchange between the two men despite their disagreements on issues like the existence of Hell. Brainerd concluded his description of this exchange by noting that most other Indians considered the powwow to be "a precise zealot, that made a needless noise about religious matters," yet in his evaluation Brainerd concluded "there was something in his temper and disposition that looked more like true religion than anything I ever observed amongst other heathens."1 Despite this positive exchange he had few good words regarding the other Indians on Juncaunta Island, for their close proximity to "white people" who continually supplied them with liquor and "the ill examples of nominal

\footnotetext{
${ }^{1}$ Jonathan Edwards, ed., The Life and Diary of David Brainerd (Peabody: Hendrickson Publishers, 2006), 300-02.
} 
Christians" made it "so unspeakably difficult to [en]treat with them about Christianity."" These brief examples highlight the complicated religious landscape of the 1740s, as Brainerd praised the revivalist zeal of an Indian powwow, even if he considered it misapplied, and deplored the behavior of English Christians deemed unregenerate by revivalist standards.

The instability and contested nature of the Calvinist revivals of the 1730s and 1740s proved impossible to disguise or fully contain in the writings of David Brainerd and other missionaries. The fact that Brainerd offered several qualifications regarding the behavior of Housatonic and Delaware Indians experiencing revival serves to illustrate the continued ethnographic fascinations with the workings of grace in people of an "inferior" civilization. Brainerd's writings also demonstrate an awareness shared by himself and Jonathan Edwards regarding the challenges revivalists faced, particularly when Native Americans were involved. The purpose of this chapter is twofold: first, it seeks to trace the central issues puritans and Indian Christians faced prior to the growth of evangelical revivals, which began with the infamous Boston earthquake in 1727 and the Northampton revival engineered by Jonathan Edwards in 1735. Second, it seeks to explore the interrelationship between revivalism and Native American communities, along with the tension borne out by the growing racialized distinctions drawn against the region's indigenous inhabitants. Traditionally, the discourse surrounding the growth and nature of evangelical revivalism during this period centers exclusively on the debates between Anglo "Old Lights" and "New Lights," with growing recognition of a spectrum of positions more accurately encompassed by terms "radical revivalist," "moderate revivalist," and "antirevivalist." ${ }^{3}$ Recent works by historians of Native America have similarly described the pragmatic side of Indian engagement with revivals, highlighting their recognition of the potential

\footnotetext{
${ }^{2}$ Ibid., 302.

${ }^{3}$ Thomas S. Kidd, The Great Awakening: A Brief History with Documents (Boston: Bedford/St. Martin's, 2008), viiviii, 14-17.
} 
for greater inclusion within Anglo society as evidenced by the rhetoric of social levelling and the diverse crowds drawn by itinerant revivalists and the acquisition of literary skills which served to benefit Indian communities. ${ }^{4}$

However, previous studies have failed to adequately assess the appeal of new religious ideas and practices beyond revivalism's promises of inclusion to study the theological messages driving revival and their appeal to Indian audiences. Similarly, studies of the religious debates during the first half of the eighteenth century center their focus exclusively on the importance of these developments for Anglo parishioners. Debates regarding the role and purpose of communion brokered by Solomon Stoddard's innovations in his Northampton church, and the debates unleashed by the revivalism of Jonathan Edwards, George Whitefield, Gilbert Tennent, and others held implications for both the Native American communities which persisted beyond the deaths of John Eliot and Thomas Mayhew, and the new missionary communities spurred into creation with the growth of evangelical fervor and the missionary work of the Anglican Society for the Propagation of the Gospel (SPG) and Presbyterian Scottish Society for the Propagation of Christian Knowledge (SSPCK). In keeping with previous chapters, particularly the third one detailing the debates surrounding the creation of the Half-Way Covenant in 1662, this chapter reveals the tenuously shifting theological ground within New England, and the implications of these debates and developments for Native Americans who chose to affiliate with Englishmen in specifically religious terms. It also demonstrates that the concept of an "Indian Christian" informed developments in colonial theology in the case of revivals.

\footnotetext{
${ }^{4}$ Linford D. Fisher, The Indian Great Awakening: Religion and the Shaping of Native Cultures in Early America (Oxford: Oxford University Press, 2012), 65-71. Julius H. Rubin, Tears of Repentance: Christian Indian Identity and Community in Colonial Southern New England (Lincoln: University of Nebraska Press, 2013), 114. Edward E. Andrews, Native Apostles: Black and Indian Missionaries in the British Atlantic World (Cambridge: Harvard University Press, 2013), 107-124.
} 
While revivalism offered a number of compelling arguments for the inclusion of Native Americans within a generalized Christian fellowship, opponents to this pietistic movement linked the emotive aspects of revivals with natural, unenlightened man. The arguments behind the antirevivalist attack, particularly those framing revivalism as degenerative, are important to examine in light of the continued discourse on Native American origins and status in the natural world, along with the potential English ministers saw in their conversion and adoption of Protestant religion. A moderate position promoted by the likes of Jonathan Edwards and David Brainerd sought to bridge this gap through the example of Indian Christians and the regenerative grace observed by missionaries at the forefront of the movement. By arguing that even Native Americans exhibited the ideal behavior of converts, moderate defenders of revival sought to once again marshal representations of Native Americans as examples of true piety and to validate their theological beliefs regarding revivals. As Native Americans lived at the confluence of material changes brought about by rapidly expanding settler colonialism after King Philip's War, the growth of transatlantic commerce and markets (which similarly facilitated the spread of revivalism), and territorial wars between French, English, and Indian combatants, they also found themselves involved in immaterial debates brokered by philosophical, religious, and scientific developments. This chapter seeks to restore Native Americans as participants in this discourse and as an ever-present component to the developments of colonial theology, despite their neglect by contemporary historians. ${ }^{5}$

\footnotetext{
${ }^{5}$ For instance, in an analysis of Narragansett involvement with Awakening revivals, William S. Simmons highlights five push factors for native participation: social stratification and class conflict within indigenous communities, the challenges of being subsumed within a dominant culture, alienation of groups as Indian Christians split into distinct denominations, conflicts with sachems over community decisions and values, and the desire for regeneration and continuity within Indian lifeways. Absent from this analysis is the importance of changing colonial theologies, particularly with Stoddard's sacramental innovations, which this chapter seeks to address. William S. Simmons, "Red Yankees: Narragansett Conversion in the Great Awakening," American Ethnologist 10 (1983): 264.
} 
This chapter begins with an exploration of the issues facing religious Indian communities prior to the growth of revivals by outlining the role of the church and religious practices within native spaces like Natick, Punkapoag, and Christiantown on Martha's Vineyard. Though records like baptismal roles survive in truncated and incomplete forms, some records from missionaries during this period survive, as do reports authored by leaders of the colony's missionary company, including Increase Mather. These English reports, along with religious publications in Algonquian languages and the marginalia found in Eliot Bibles kept by Indian members of these communities serve to offer a glimpse at what religious expression meant to Indian Christians in these places as they weathered temporal storms, however incomplete and silent at times the sources are. The writings of English ministers involved with these communities, such as Experience Mayhew, also serve as a barometer for their thoughts regarding Indian Christians in the wake of King Philip's War and their receptivity for including Indians within the ecclesiastical polity of the colony.

English colonists faced their own issues during the first half of the century, as the religious fervor that anticipated and followed King Philip's War subsided and ministers resumed preaching thundering jeremiads to encourage young church members to "own the covenant." The next section explores the issues facing English communities and the efforts of ministers to combat what they believed to be a decline in religious piety, as evidenced in Solomon Stoddard's innovations to open the communion table to all congregants as a converting ordinance. I also seek to point to areas where this discourse impacted or concerned Indian Christians and how they potentially factored into these debates through the writings of Experience Mayhew. The colony also faced continued war with French Canada and their Indian allies during this period. The division between Protestant England and Catholic France added a religious tincture to this 
conflict, which complicated the later efforts of revivalists who journeyed to areas where Indians had already experienced Christianity through Jesuit priests. The 1735 Northampton revival did not occur in isolation, as a number of revivals promoted most notably by Solomon Stoddard paved the way for the growth of a larger movement, so it is worthwhile to first consider the potential appeal of these early religious stirrings to Native Americans as well. The growth of deism and rationalism, along with the political imperative towards greater religious toleration within New England also presented further religious challenges to orthodoxy within the region. ${ }^{6}$ More intense revivals marked the period from 1735-1750, facilitated by the transatlantic promotions of George Whitefield and his colonial supporters, as well as homegrown revivalists and itinerants within the colony. ${ }^{7}$ The third section of this chapter explores the growth of revival in an indigenous context to determine the theological appeal of the movement from the perspectives of Indians who approached the English, and Englishmen who chose to approach Indians in the wake of evangelical fervor. The theological innovations of revival once again cleared a path where Englishmen and Indians could meet to seek common ground, albeit under drastically different circumstances compared to the encounters of the previous century.

\footnotetext{
${ }^{6}$ Frank Lambert, Inventing the “Great Awakening” (Princeton: Princeton University Press, 1999), 3-13, 62-65. Lambert aptly characterizes the revivals as a series of events constructed by Englishmen on both sides of the Atlantic. In his second chapter he also highlights the predicate revivals promoted by Solomon Stoddard in 1679 , 1683, 1696, 1712, and 1718. As Stoddard's grandson and assistant, Jonathan Edwards learned from his relative the importance of seeking out the youth to inculcate revivalist stirrings. Michael J. Crawford writes of Protestants in the 1730s: "a clear sense of crisis, an urgent defense of orthodox doctrine against the rationalist assault, is unmistakable in the writings of these evangelicals." Michael J. Crawford, Seasons of Grace: Colonial New England's Revival Tradition in Its British Context (Oxford: Oxford University Press, 1991), 141.

${ }^{7}$ Frank Lambert, "Pedlar In Divinity": George Whitefield and the Transatlantic Revivals, 1737-1770 (Princeton: Princeton University Press, 1994), 3-8, 46-51. Lambert writes that Whitefield's use of commercial language and metaphor "indicates the assimilative powers of Christianity to re-present itself through transformations, including that of the marketplace." In a similar vein, this chapter argues that Christianity within New England developed alongside and in consideration of the paradoxical nature of Indian conversion. Timothy D. Hall, Contested Boundaries: Itinerancy and the Reshaping of the Colonial American Religious World (Durham: Duke University Press, 1994), 5-14, 41-44. Established clergymen often saw revivalism as a threat to the colonial and parish order established by New England's founding generation in emulation of English parish structure, especially after homegrown revivalists became prevalent following Whitefield's tour through the colonies.
} 
Finally, this chapter traces the discourses and debates surrounding the efficacy, nature, and propriety of revivalism within the context of parallel discussions on the state of Indians and their potential for "civility." Antirevivalist diction frequently tarred their opponents with accusations of ignorance, emotional fervor, disorder, and incivility, which deserves particular analytical focus when read in conjunction with the concurrent rhetoric surrounding Indians as natural, fallen barbarians. These accusations gained even greater credence as news of Indian participation in revivals spread and served as a powerful impetus for the conservative camp to oppose revivalism. While radicals continued to paint their opponents as unregenerate and pharisaical in emphasizing the importance of emotive piety, moderate ministers like Jonathan Edwards, Stephen Williams, and David Brainerd sought to utilize Indian Christians as examples in support of revivalism. ${ }^{8}$ Indian behavior and responses to sermons and revivalist theology served to validate the potential of evangelical revivalism to promote thorough spiritual change as well as an orderly progression towards civility. Despite this positive portrayal of Indians within the context of revivalism, the growing racialized distinction of Indians and African American slaves as "others" developed simultaneously out of this discourse on origins and the potential for spiritual regeneration, a topic continued in the following chapter.

\section{Religiosity and Indian Christian Communities, 1700-1735}

The families who made up Indian Christian enclaves within Massachusetts Bay, Plymouth, and Martha's Vineyard differed in their continued engagement with puritanism over the course of the opening decades of the eighteenth century. From their inception, the mixed

\footnotetext{
${ }^{8}$ I mention Edwards as a moderate because he definitely veered into that camp after his expulsion from Northampton, but it is clear even in his early writings that he took this position. The expulsion only served to solidify this position and forced him to articulate it with greater clarity. See M. Darrol Bryant, Jonathan Edwards' Grammar of Time, Self, and Society: A Critique of the Heimert Thesis (Lewiston: Edwin Mellen Press, 1993), 89104.
} 
nature of Indian populations and the tendency to continue in seasonal migrations throughout the colony frustrated the desires of puritans to create closed, corporate communities where Indians passively learned to emulate English standards of civility and piety. Though King Philip's War collapsed the number of mainland Christian Indian enclaves to just four towns, the English proved unable to permanently bind Indians to these tracts of land, making it difficult to accurately assess population figures and the daily participation of individual residents in the religious life of these communities. ${ }^{9}$ Despite this demographic challenge, reports authored by colonials engaged with the project as CPG members and missionaries to the Indians provide glimpses of the indigenous church within these communities, along with its nature, central rituals, and meaning to individuals who survive in the colonial record through their personal writings or oral stories set to paper by English intermediaries. Temporal issues facing these communities also shaped the evolution of the church as an institution, leading to divergent paths when the mainland and island enclaves undergo comparison. Finally, it is worthwhile to consider the evaluations authored by English ministers in order to ascertain the general standing of Indian Christians as a distinct facet of the colony's religious community within the wider colonial body and the disposition toward them.

\footnotetext{
${ }^{9}$ Jean M. O'Brien "They are so frequently shifting their place of residence": land and the construction of social place of Indians in colonial Massachusetts," in Martin Daunton and Rick Halpern, eds., Empire and Others: British Encounters with Indigenous Peoples, 1600-1850 (Philadelphia: University of Pennsylvania Press, 1999), 204-216. See also Daniel Vickers, "The First Whalemen of Nantucket," in Colin G. Calloway, ed., After King Philip's War: Presence and Persistence in Indian New England (Hanover: University Press of New England), 90-113. On the precarious nature of slavery, servitude, and economic survival, see the following: Margaret Ellen Newell, "The Changing Nature of Indian Slavery in New England, 1670-1720," in Reinterpreting New England Indians and the Colonial Experience, ed. Colin G. Calloway \& Neal Salisbury (Boston: The Colonial Society of Massachusetts, 2003), 106-136. Ruth Wallis Herndon and Ella Wilcox Sekatau, "Colonizing the Children: Indian Youngsters in Servitude in Early Rhode Island," in Reinterpreting New England Indians and the Colonial Experience, ed. Colin G. Calloway \& Neal Salisbury (Boston: The Colonial Society of Massachusetts, 2003), 136-173. Nan Wolverton, “"A Precarious Living': Basket Making and Related Crafts Among New England Indians," in Reinterpreting New England Indians and the Colonial Experience, ed. Colin G. Calloway \& Neal Salisbury (Boston: The Colonial Society of Massachusetts, 2003), 341-368.
} 
At the start of the eighteenth century the colonial leaders of the CPG and their English benefactors agreed that an assessment of the state of Indian Christian religion given the "signal blast of heaven on ye Indian work" with the deaths of Eliot, Mayhew, and "many of the most pious Indians (both professors \& preachers)" at the close of the previous century. ${ }^{10}$ The commissioners sent two English ministers with experience preaching to the Indians in the colony on a journey throughout the region and compiled a report to the governor of the corporation, William Ashurst. ${ }^{11}$ The report found that thirty Indian Christian congregations gathered every Sunday, with numerous smaller gatherings meeting throughout the week for lectures and worship on top of the Sabbath gathering. These communities received the support of about thirty-seven Indian preachers who ministered to their brethren in Algonquian dialects with the aid of catechisms, bibles, and psalmodies translated from English. Seven or eight English ministers worked with them at times to assess the progress of these churches from gathering to covenanted church, and they also oversaw the ordination of Indian pastors. ${ }^{12}$ While Indian-centered religiosity clearly dominated the day to day practices of these communities, the emphasis on English oversight demonstrates the distinction between truly independent Congregationalist churches composed solely of English colonists and Indian churches, which generated English suspicions and mistrust. Mather observed that the Indians faced decline compared to the heyday of the project, as "The Hand of God, has very strangely wasted them, and the War which they

\footnotetext{
${ }^{10}$ Ford, ed. Some Correspondence Between the Governors and Treasurers, 80-81. Kristina Bross asserts that the death of Indians served missionary aims, as their lives were contained and ended by death in such a way that missionaries could construct accounts of piety in life and death without the complications of backsliding or apostasy. Kristina Bross, Dry Bones and Indian Sermons: Praying Indians in Colonial America (Ithaca: Cornell University Press, 2004), 186-90.

${ }^{11}$ Ford, ed., Some Correspondence Between the Governors and Treasurers, 82-83. The colonial commissioners also ordered the printing of this letter in Boston in 1705, presumably to alert colonials to the present state of the missionary project within the colony.

${ }^{12}$ Increase Mather, A Letter, About the Present State of Christianity, among the Christianized Indians of NewEngland. Written, To the Honourable, Sir William Ashhurst, Governour of the Corporation, for Propagating the Gospel among the Indians, in New-England, and Parts Adjacent, in America (Boston, 1705), 4-7.
} 
began upon the English in the Year, 1675. hastened a strange Desolation upon whole Nations of them." ${ }^{13}$ Though the trope of Indian decline became increasingly commonplace in the eighteenth century, the persistence of Indians in these communities remains self-evident.

A brief comparison of the divergent ecclesiastical histories of Natick and Martha's Vineyard serve to highlight the changing roles of the church in Indian Christian enclaves. Following Eliot's death in 1690, Indian preacher Daniel Takawombpait served the community as minister for about thirty years until his death in September 1716. After a gap of almost a decade, Oliver Peabody began preaching at Natick in 1725 and was ordained in October 1729 as the town's minister after a special commission found that only sixteen Natick men and twelve children had undergone baptism. ${ }^{14}$ Peabody "thought proper that as ye affairs then were, a Church should be gathered partly of Indians and Partly of English belonging to Natick," but only managed to gather three Indians and four other Englishmen living in the community as the founding members in 1730. The small church elected Indian Joseph Ephraim and Englishman Ebenezer Felch as its first deacons. ${ }^{15}$ By contrast, the 1705 report on Indian affairs found that

\footnotetext{
${ }^{13}$ Ibid., 5.

${ }^{14}$ Ives Goddard and Kathleen Bragdon, eds., Native Writings in Massachusett, I (Philadelphia: The American Philosophical Society, 1988), 11. Hilary E. Wyss argues that "Native inclusion was an abstraction; practically speaking, Indian churches remained segregated and in the eyes of many were inferior to English churches," so it is worthwhile to point out the significance of the Natick experiment. Hilary E. Wyss, Writing Indians: Literacy, Christianity, and Native Community in Early America (Amherst: University of Massachusetts Press, 2000), 63. Daniel R. Mandell contends that the second quarter of the eighteenth century "generated even more rapid changes in Indian communities" as the "decline of the Indians" protective seclusion became even more apparent as all native groups were forced to confront the growing problem of trespass, fraudulent land sales, and poaching." As such, some chose to adopt English practices with even greater fervency, which offers a potential motivation for engaging with Christianity. Daniel R. Mandell, Behind the Frontier: Indians in Eighteenth-Century Eastern Massachusetts (Lincoln: University of Nebraska Press, 1996), 80-81.

${ }^{15}$ Natick Federal Savings and Loan Association, The Story of Natick (Natick: Suburban Press, 1948), 6. Oliver Peabody, "Natick Church Records," Ms. S-141, Massachusetts Historical Society, 1-2. The founding members of the new integrated church at Natick included the following Indians: Joseph Ephraim, John Brooks, and Joseph Ephraim, Jr. Englishmen in addition to Peabody included Samuel Ames, Ebenezer Felch, Thomas Dunton, and James Beals. It is likely that the small number of Indian supporters stemmed from the skepticism Natick's Indian population had toward Englishmen that was rooted in the wartime memory of King Philip's War. Decades of autonomy likely ensured that religious practices continued outside of Peabody's experimental mixed church, as Natick's Indians continued to possess texts composed in Algonquian and a respectable degree of literacy. Also important was the demographic shift that began around 1720 in which Natick saw a greater number of Englishmen
} 
Wampanoag on Martha's Vineyard had almost exclusively adopted Christianity to the point that "there are no more than Two Persons, which now remain in their Paganism" out of the estimated 180 families on the island. Emerging largely unscathed from the mainland wars of the previous century, the Wampanoag of Martha's Vineyard took more proactive measures to cultivate ties with white allies like Matthew Mayhew and the dissolution of the sachemship as a form of government in favor of communal decision-making through the institution of the indigenous church. $^{16}$

Given the paucity of detailed sources on indigenous piety during this period, it is difficult to ascertain the exact nature of religiosity within these communities. Increase Mather's 1705 report contained extracts from a minister named Josiah Torrey, who worked directly with the Indians and offered the following evaluation of religion within his community: "their Gravity and diligent Attendance in the Time of Worship, with the affectionate Confessions of such as are Admitted into the Church" implied the work of the Holy Spirit among them, as "Their method, respecting those that are Admitted into their Church Communion, is more according to the manner of the Churches in the Primitive Times, than is now practiced among the Churches in most parts." ${ }^{\prime 17}$ Torrey's observation suggests that Indian Christians continued the practice of

purchasing land and taking on roles in town and church governance. Jean M. O'Brien, Community Dynamics in the Indian-English Town of Natick, Massachusetts, 1650-1790 (Dissertation, University of Chicago, 1990), 198. Drew Lopenzina suggests that the marked absence of spiritual language in surviving Natick Indian town records from this period implies an absence of religious devotion, which underestimates the significance of oral culture and religiosity, along with the pragmatic (and admittedly secular) focus of documenting land allotments. Drew Lopenzina, Red Ink: Native Americans Picking Up the Pen in the Colonial Period (Albany: State University of New York Press, 2012), 204.

${ }^{16}$ Mather, Present State of Christianity, 5. See especially Chapter 4 in David Silverman's Faith and Boundaries, entitled "Deposing the Sachem to Defend the Sachemship." David J. Silverman, Faith and Boundaries: Colonists, Christianity, and Community among the Wampanoag Indians of Martha's Vineyard, 1600-1871 (Cambridge: Cambridge University Press, 2005), 121-156. Kinship ties also played an important role in binding English and Indians together, as seen in the example of Joseph Dagget to the sister of Thomas Sissetom, an Indian minister and the marriages Jon Daggett arranged between his son Thomas and Hannah Mayhew, and his son Joseph and the daughter of a Wampanoag sachem. Kathleen J. Bragdon, Native People of Southern New England, 1650-1775 (Norman: University of Oklahoma Press, 2009), 119, 127-28.

${ }^{17}$ Mather, Present State of Christianity, 8. 
examination and scrutiny of one's spiritual journeys in spite of the recent innovations spreading in the colony with Solomon Stoddard's opening of the communion table to all as a converting ordinance. According to Torrey, the communities he observed continued to relate to their examiners their doctrinal knowledge, moments of doubt, confessions of sin, and an account of their experiences leading to conversion, which convinced him that "There are many, which maintain a Christian Conversation, and are to be accounted, not Almost, but Altogether Christians." 18 Vital records from the town of Natick show that many Indian families, including the Awansamug, Comecho, Ephraim, Paukenit, Peegun, Speen, Waban, and Wamsqan clans consistently baptized their children at birth throughout the early decades of the eighteenth century. If complete disinterest marked Natick during this period as scholars have suggested, these patterns instead demonstrate a rise in affiliation with Peabody's church that predates the spread of revivals in the 1740s and suggest that the prospects of a mixed English-Indian church seemed promising to some families. ${ }^{19}$

The continued presence of Indian-language religious texts and efforts to attain literacy ensured that Indians maintained a level of individual piety that often went unrecorded or obfuscated by scanty documentation in the colonial record. Kathleen Bragdon suggests that about thirty percent of the indigenous population was literate by 1700 , and that the textual nature

\footnotetext{
${ }^{18}$ Ibid., 8-9. Torrey continued on to stress that the Indians maintained orthodox practices regarding communion, marriage, church discipline, and excommunication. Stoddard implemented this policy as early as 1679 when he abandoned the complex bookkeeping practices necessary to keep track of the spiritual status of a congregation of visible saints. Pope argues that Stoddard's theological developments were unoriginal, nor were they radical. In the context of enlarging the spiritual community to include Native Americans, Pope's conclusions deserve reevaluation. Robert G. Pope, The Half-Way Covenant: Church Membership in Puritan New England (Princeton: Princeton University Press, 1969), 253-57.

${ }^{19}$ Thomas W. Baldwin, Vital Records of Natick Massachusetts, To the Year 1850. (Boston, 1910), 10-11, 28-29, 37 $38,73-75,95,102$. Other families entered their children into the baptismal record, but these represent the most substantial entries with the greatest number of family members baptized. Dane Morrison is most critical of the missionary project, arguing that piety died with Eliot as "Massachusetts Bay Colony made the Algonkian a marginal people and accorded them a place only on the periphery of colonial society," as a result of "institutionalized intolerance." Dane Morrison, A Praying People: Massachusetts Acculturation and the Failure of the Puritan Mission, 1600-1690 (New York: Peter Lang, 1995), 188-89.
} 
of Protestant religion inexorably linked piety and literacy for Indians. ${ }^{20}$ The commissioners of the New England Company began to publish shorter works in indigenous languages and stressed more than ever that Indians should make efforts to learn English after Eliot's death. Among these works were translations of sermons by Increase Mather and original writings of Cotton Mather, including a primer and catechism for children. The company issued new editions of Eliot's Indian Primer and a translation of John Cotton's Spiritual Milk for Boston Babes, but a third printing of the Eliot Bible failed to gain funding after Cotton Mather convinced the company that they must push Indians towards the adoption of the English language and that continued publications in Algonquian undermined that goal. ${ }^{21}$ Though colonists burned many Indianlanguage texts on the mainland during King Philip's War, marginalia from surviving Eliot Bibles attests to indigenous engagement with the text, religious piety, and the sense of community writing engendered. For instance, the will of Naomai Omaush expresses a belief in the spiritual regeneration after her body has decayed, where "we shall dwell with the lord forever." Marginalia in the Book of Isaiah from one Wampanoag bible reads: "Therefore we are pitiful,

\footnotetext{
${ }^{20}$ Bragdon, Native People of Southern New England, 1650-1775, 181-83. E. Jennifer Monaghan examines literacy among the Wampanoag to suggest that literacy was attained in an almost exclusively religious capacity, and that a decline in literacy during the 1760-70s followed by growth in the 1780-90s coincides with a marked shift towards bilingualism and a focus on learning solely English with later missionaries. Additionally, Monaghan argues that institutional education within the native church was supplemented by home schooling from friends, family, and neighbors. E. Jennifer Monaghan, Learning to Read and Write in Colonial America (Amherst: University of Massachusetts Press, 2005), 75-79. In his missionary journals to the Pequot and Mohegan during 1713-14, Experience Mayhew noted that the Pequot "shewed themselves pleased at the proposal of learning them to read \& write," and that Benjamin, the brother of his Indian translator Joseph, was willing to send his seven year old son to be trained as a minister with Mayhew's compatriot. His meetings with the Mohegan proved to be less optimistic, as the Mohegan sachems seemed interested enough in their children obtaining literacy, but incisively questioned Mayhew on the problem of hypocrisy they observed among Englishmen regarding religion. They also emphasized that "as several nations had their distinct way of worship, so they had theirs; and they Thought their way was Good, and that they had no reason to alter it." In the case of the Mohegan, the connections between literacy and religion seemed too great a cost. Ford, ed. Correspondence between the Governors and Treasurers, 101, 109, 111-12, 117 20.

${ }^{21}$ Monaghan, Learning to Read and Write, 66. Monaghan also notes that the differences between the original Eliot edition of the primer and the 1720 printing, which "fairly oozed with anti-Indian prejudice and negative stereotyping." Ibid., 79. Sarah Rivett contends that the shift following King Philip's War coincided with the Lockean dismantling of universal language theory and refinement of Indians as an anthropological relic rather than part of a common humanity that must be unified. Sarah Rivett, The Science of the Soul in Colonial New England (Chapel Hill: University of North Carolina Press, 2011), 170-72.
} 
because of our sin," while another entry in Numbers says "Pitiful people (are) we. It is not good." As books traveled within their communities, many natives inscribed messages and admonitions to each other, as a note read "I Samuel say this to you Papenau: if you pray hard to your God..." while the same page states that the book belongs to Joseph Papenau on July 22, 1712. Papenau continued to inscribe messages to himself, such as "This is your book, you Papenau. Read it with c[oncentr]ation (?). Your God will bless you," along with messages to "all you my friends" crammed into the margins of the text. ${ }^{22}$ Undoubtedly, the survival of a greater number of writings possessed by Indian Christians communities would tell a similar story, as another bible from the Chappaquiddick community owned by the Seiknout family recorded family deaths and an admonition for a reading audience to "remember the law," for "with that you (singular) will be saved unto salvation" in addition to the note "forsake your (plural) sins."23 This ongoing dialogue with the text, supported by oral discussions and the preaching of Indian Christian ministers, suggests the sustained presence of indigenous piety despite the notable silences in the archives.

Temporal concerns frequently intersected with religious issues, which colored English evaluations of Indian Christians and their integration into the wider colonial society of the early eighteenth century. For instance, The English branch of the CPG authorized a purchase of land by Lord Lymerick in Martha's Vineyard in 1711 to keep the Indians bound to the land and from "being scattered up and down the Continent, and returning to the barbarous Customes of their Ancestors.” Though it is difficult to ascertain the Indian role in this exchange, the fact that

\footnotetext{
${ }^{22}$ Goddard and Bragdon, eds., Native Writings in Massachusett, 55, 409, 423-25. Wyss argues that native writings served as an effort to insert Indians into colonial literature by "defining their place in a newly forming colonial structure, positioning themselves simultaneously as Native Americans and as colonial subjects," and that this marginalia demonstrates how writing helped "create and maintain a community that is a product of colonialism but is at the same time rooted in a traditional Native identity." Wyss, Writing Indians, 3-5.

${ }^{23}$ Goddard and Bragdon, eds., Native Writings in Massachusett, 458-61.
} 
Ashurst mentioned the fear of descent into barbarism to both Governor Nicholson and Increase Mather in two separate letters suggests that this issue drove his decision to protect Indian Christian land rights. ${ }^{24}$ Increase Mather reported in 1705 that the first generation of Eliot converts was assured of salvation, but that many of the "Censorious English" did not think highly of their contemporaries, arguing that "there were Three or Four Persons in that Plantation, who, they verily believed, were Sound Christians, tho they Condemned the rest." This seemed grossly unfair to Mather, who suggested that these were but the most pious of Indian Christians and that the others still had "a just Foundation to home, That they are Travelling the right way to Heaven" as any puritan might, given the propensity to doubt one's election. ${ }^{25}$ In the introduction to his biographical sketches of pious Wampanoags entitled Indian Converts (1727), Experience Mayhew began the introduction of his text by chastising Englishmen "who will hardly be persuaded that there is any thing of sincere Religion or Godliness among this poor People," and those who simply thought little of it, lamenting the disinterest in gospel work among many colonists. ${ }^{26}$ Despite these positive reports, missionaries and English ministers intimately acquainted with Indians recorded instances of drunkenness among Indians in these communities with greater frequency than before. In the case of Natick, Joseph Ephraim, Jr. confessed to intemperance and sought restoration within the church in 1734. Church records show that Thomas Peegun confessed similar indiscretions to Peabody and the deacons two years later. During his missionary journey to the Pequot and Mohegan, Experience Mayhew expressed

\footnotetext{
${ }^{24}$ Ford, ed., Some Correspondence Between the Governors and Treasurers, 94-96.

${ }^{25}$ Mather, Present State of Christianity, 9-11.

${ }^{26}$ Laura Arnold Leibman, ed., Experience Mayhew's Indian Converts: A Cultural Edition (Amherst: University of Massachusetts Press, 2008), 91. Erik R. Seeman's methodological essay on reading Indian deathbed scenes offers particularly insightful warnings pertaining to the idealistic nature of these texts from the perspective of European authors like Mayhew, as well as an ethnological and representational model to read them for aspects of a native voice. European authors wrote primarily for a European audience to validate their successes as missionaries. Erik R. Seeman, "Reading Indians' Deathbed Scenes: Ethnohistorical and Representational Approaches," The Journal of American History 88 (2001): 17-22, 25.
} 
disappointment because his interpreter Joseph had "been overtaken with drink, once at least," though Mayhew hoped to continue working with him. ${ }^{27}$ In a sermon written out in both Algonquian and English, missionary Josiah Cotton similarly singled out drunkenness and the susceptibility of Indians to follow the advice of bad Englishmen seeking to debauch them, writing: "How long O Ye Indians will you be a needy, miserable, false, Drunken People, How long will you let Drink be your master... you are beast \& not men if you have not reason enough to command your evil appetites." 28 Given the increased pressures Indian Christians felt throughout this period when it came to English encroachments and the poverty that they began to face as unequal players in the colonial economy, drunkenness potentially forced English ministers to focus on Indians and the issues they faced. The historical aid given by missionary organizations and the usefulness of ministers in these negotiations was not lost on Indians, so it is possible that discontented individuals appropriated drunkenness in order to highlight an imbalance of reciprocity and care that traditional sachems or benefactors were to bestow upon a community. ${ }^{29}$

\footnotetext{
${ }^{27}$ Peabody, "Natick Church Records," Ms. S-141, MHS, 5-6. Ford, ed., Some Correspondence Between the Governors and Treasurers, 125-27. Before Mayhew found out about Joseph's behavior, he recorded a discussion with a Mohegan powwow in which the powwow claimed that his people would assent to Mayhew's teaching, but that they would just return to drinking once Mayhew left, stressing that there existed by this point a divide between the young and old men within their community. Hilary Wyss argues that Indians recognized the freedom and revelry that resulted from native drinking and inebriation and how this upset the English, suggesting that drinking was often a strategic or symbolic action which appropriated a negative role in order to express dissent or disapproval with particular actions, as evidenced by the timing of Umpachenee's drunkenness and the Sergeant-Williams marriage. Wyss, Writing Indians, 97-103. Cases of theft and other legal issues also appear sporadically in the archival record, such as a 1720 incident where an Indian of Weston named Joshua Ompatawin was accused of stealing a black mare from a colonist. Letter, "Francis Fullam Report, Feb. 17, 1720/1," Ms. 305, Edward Ayer Collection, Newberry Library.

${ }^{28}$ Josiah Cotton, “Indian Sermon,” 12 Feb 1709/10. Ms. 1592, Newberry Library, 8-10, 18. Cotton's audience likely found this a difficult and patronizing sermon to sit through. Josiah Cotton took up the mantle of his father, John Cotton, Jr. and preached to the Indians at Monument Pond in Plymouth for roughly forty years until his death. Goddard and Bragdon, eds., Native Writings in Massachusett, 12. If Cotton's records on sermons preached from 1716-17 are representative of his regular ministry, then he delivered Indian sermons roughly three to four days a month, and typically gave two sermons on those days. Josiah Cotton, "List of Religious Services Held, 1716-1717." Misc. 1717 Sept. 15, MHS.

${ }^{29}$ Hilary Wyss suggests that Umpachenee's drunkenness at the strategic moment of John Sergeant's marriage into the Williams clan is an example of such a gesture, as the Stockbridge Indians tangled with members of the Williams
} 
Experience Mayhew's accounts of Wampanoag lives frequently stress the debilitating effects of alcohol consumption and the marked transition away from drunkenness to sobriety that frequently accompanied rededication of Indian baptismal covenants and owning the covenant as full members. Samuel Coomes served as an example of this phenomenon, for he renewed his covenant after the death of his father "with much Seriousness and Affection" and began to "set up the Worship of God in his House, praying Morning and Evening in his Family as long as he lived." Coomes learned to read the Scriptures translated into his native language and led his family in psalm-singing and catechesis. ${ }^{30} \mathrm{He}$ also stressed the importance of literacy to Indian Christian piety, as he mentioned that an Indian deacon and preacher named Abel Wauwompuhque read Lewis Bayley's Practice of Piety before morning and evening prayers, along with Experience Mayhew's own translation of The Massachuset psalter (1709). Noting that Wauwompuhque "delighted much to read and meditate therein," Mayhew stated that he "carried it about with him wherever he went to work, and whenever he sat down to rest him, he would look into it." ${ }^{31}$ At his deathbead, Wauwompuhque urged his family to continue to follow in his religion and expressed his hope that he would move on to heaven.

Regardless of the issues at hand, these communities continued to persist both physically as distinct groupings of indigenous people, and religiously as hybridized practitioners of a colonial faith that remained Indian in expression and form. ${ }^{32}$ The proliferation and longevity of Algonquian-language texts produced in the previous century and into the eighteenth century continued to sustain these communities, as evidenced in the marginalia found within surviving

family previously. In a state of inebriation, drunken men and women received a modicum of freedom of selfexpression uninhibited by traditional restraint as well. Wyss, Writing Indians, 95-103.

${ }^{30}$ Leibman, Experience Mayhew's Indian Converts, 185-87.

${ }^{31}$ Ibid., 163-64.

${ }^{32}$ Again, Seeman's work on deathbed scenes highlights the syncretic activities that missionaries like Experience Mayhew sought to nudge into orthodox categories at times. Seeman, "Reading Indians' Deathbed Scenes," 40. 
Eliot Bibles and the communal focus of many of these annotations. Texts exchanged hands many times over the years, and it is unfortunate that there is no way to fully document the extent of piety through its oral channels. The divergent nature of institutional piety in Martha's Vineyard and Natick serves to highlight the differences in experience both communities experienced during and after King Philip's War. While the Martha's Vineyard community relied increasingly on the church as an institution within the community, the residents of Natick proved far more reticent to partner with the English once Oliver Peabody founded a joint Indian-English church to serve the growing number of English residents in Natick. ${ }^{33}$ Despite positive assessments of Indian Christian piety, much of the writing about Indians in this period tended towards pessimism and negative conceptions of Indian potential or seek to respond to commonplace arguments their authors faced within the colony at large. Given the importance of the colonial setting - including Indians - as a shaping factor for colonial theology, it is worthwhile to consider portrayals and arguments pertaining to Indians as both point and counterpoint in the theological developments within New England prior to the spread of revivalism.

\section{Defenders and Detractors: Indians and Puritan Theology before Revivalism}

The evolution of colonial theology within puritan New England unfolded in the face of both external and internal complications despite the charter security the colony gained in the wake of the Glorious Revolution of 1688 and the material prosperity that came with the growing transatlantic commerce of the century. Externally, ministers faced continued indifference when it

\footnotetext{
${ }^{33}$ The Stockbridge experiment faced similar issues of contentious Indian participation and church membership, as the four white families who joined Sergeant to found the Stockbridge mission quickly tangled with their Indian neighbors over issues of land, dividing the town in 1744 into "distinct populations with divergent needs and desires." Sergeant admitted some fifty or sixty Indians into membership and only twelve to fifteen English persons. After his death, Stephen West admitted 504 people to church membership, with only twenty-two Indians in that figure. Leibman, Experience Mayhew's Indian Converts, 84-85.
} 
came to church membership and the small number of people willing to "own the covenant" and describe their conversionary experience. ${ }^{34}$ Ministers continued to preach jeremiads in order to stoke their congregants out of the indolence that they believed was a product of material and physical security. Geopolitical acrimony between Britain and France also contributed to a string of borderlands conflicts which included Native Americans, though they lacked the scope and ferocity that took place decades earlier during King Philip's War. ${ }^{35}$ Puritan ministers also confronted the internal issues of assurance of salvation and the place of works in the process of sanctification, which culminated in the sacramental innovations taken by Solomon Stoddard at Northampton and his polemics with Increase and Cotton Mather. This debate held particular importance for the colony's Indian Christians, as it offered positive implications for their inclusion within the ecclesiastical body of the colony through a process of gradual conversion open to all rather than Calvinist fatalism. It comes as no surprise then that Experience Mayhew, the most widely published missionary of his day, embraced Stoddard's innovations to defend and promote them in print. Yet again, the context of the colonial experience and the continued presence of Indians, particularly those engaging to various degrees with Christian theology and practice, shaped theological concerns within New England.

Increase Mather's A Plain Discourse, Shewing Who shall, \& who shall not, Enter into the Kingdom of Heaven (1713) serves as a representative treatise from an orthodox perspective during this period. Mather opened his treatise warning readers that the most dangerous aspect of

\footnotetext{
${ }^{34}$ Jon Butler contends that the spread of numerous denominations across the British Atlantic during this period attests to the growing religious pluralism of the century, especially in the Middle Colonies. Jon Butler, Awash in a Sea of Faith: Christianizing the American People (Cambridge: Harvard University Press, 1990), 175-95. ${ }^{35}$ While John Williams' The Redeemed Captive Returning to Zion "has been called 'the masterpiece' of the captivity narrative genre, inscribing the idea of ferocious Indian attacks on vulnerable frontiersmen into the minds of succeeding generations, Evan Haefeli and Kevin Sweeny highlight the visit of John Williams' former captors to Deerfield over a decade later as an example of the ambiguity found in living away from areas of English hegemony. Evan Haefeli and Kevin Sweeney, "Revisiting The Redeemed Captive: New Perspectives on the 1704 Attack on Deerfield," in After King Philip's War: Presence and Persistence in Indian New England, ed. Colin G. Calloway (Hanover: University Press of New England, 1997), 29.
} 
the Christian life is man's capacity to deceive himself regarding salvation, for many "hope they are going to Heaven, and will not easily be beaten out of that hope, altho' they never were in the way thither." ${ }^{36}$ Disparaging natural reason and knowledge, Mather stresses that knowledge is not enough because even the Devil knows God, for "The Dim Light of Nature is not a sufficient guide to Heaven. They have that only that dont know that there is such a blessed Kingdom. Miserable Creatures! They come into the World and know not Wherefore, and go out again they know not Whither. ${ }^{\prime 37}$ Even those who make great strides to attain salvation will probably fall short according to Mather's doctrine, as only true believers who manifest the sign of "Evangelical Repentance" and "Godly Sorrow" may count themselves among the elect, and even then there is reason to doubt. Mather concludes by disparaging pagan virtue for lacking the essential belief in the Christian god, for "Some who are in their Natural Unregenerate Estate have been free from Scandalous Immoralities all their dayes, never guilty of that which the World looks upon as a great Sin." ${ }^{38}$ Encouraging self-doubt and a narrow vision of election, Mather intended to generate contemplation in his readers, spurring them to search their own souls and bemoan their own shortcomings and sin as a reason to doubt their election and strive all the more for signs of God's favor in their lives. Considered in an Indian context, Mather's sermon buttresses the dim view that solidified for many Englishmen in the wake of King Philip's

\footnotetext{
${ }^{36}$ Increase Mather, A Plain Discourse, Shewing Who shall, \& who shall not, Enter into the Kingdom of Heaven, and How far Men may go and yet fall short of Heaven, after their seeming to be Converted and Religious (Boston, 1713), 1.

${ }^{37}$ Ibid., 16-17, 23. In a collection of sermons Mather expanded on this point, arguing that men who "externally conform to the Precepts of the Moral Law" are like Jews and "Mahometan Infidels" and strangers to conversion. He also blamed the sinner and his sin for this confusion and false belief. Increase Mather, Awakening Truth's Tending to Conversion. Delivered In several Sermons Wherein is Shewed, I. That the greatest Sinners may be Converted and Saved. II. That sinners who cannot Convert themselves, ought to Pray for Converting Grace. III. That Sinners who neglect Spiritual Blessings until the Day of Grace is past, will wish for them but in vain, when it is too late. In which SERMONS notice is taken of some late Remarkable Conversions (Boston, 1710), 44, 65.

${ }^{38}$ Mather, A Plain Discourse, 17, 31, 36. Mather also stressed the limits of education, arguing surprisingly for geographic relativism in shaping religion, for "They are Christians only because they have been Born and Educated among Christians. If they had been among Mahometans or Papists or Pagans, they would have been such (54-55).
} 
War. If they were to doubt their own salvation, then even the good behavior and natural virtues of pagan Indians still fell short and rendered them damned in God's sight. ${ }^{39}$

Decades earlier Solomon Stoddard wrestled with the issue of assurance and sin after a conversionary experience in The Tryal of Assurance (1698), for those who sin after describing a conversionary experience on the road to sanctification "do make their sincerity questionable unto others: some that take notice of their falls are ready to suspect, and others are ready to deny their sincerity." ${ }^{40}$ Eschewing the consequentialist viewpoint promoted by Mather in much of his writings, Stoddard urged his readers to reject the notion that the commission of sins signaled God's anger or rejection of them or that they were not true believers in the first place. To Stoddard, the ability to recognize personal assurance within one's own life was paramount and superseded the judgment of others, for hypocrites "may counterfeit Holiness and have the image of it; but [fall] utterly short of an holy life." ${ }^{41}$ Confronting the central issue of assurance and godly community, Stoddard urged people to take confidence in their own self-examination through a long view of all their actions in life, for "It is not good to depend upon the judgment of others, for they do not know, whether a man be sincere or not. All the external acts of Charity, Piety, Justice, and Sobriety, may be performed by a man that has no Grace." While Stoddard and Mather both recognized the importance of election, their conclusions diverged: Mather continued

\footnotetext{
${ }^{39}$ In examining Increase Mather's eschatology, Linda Munk highlights the fact that Mather maintained an interest in the conversion of the Jews in The Mystery of Israel's Salvation, Explained and Applyed (1669) and his Dissertation Concerning the Future Conversion of the Jewish Nation (1709), arguing that this conversion was part of an eschatological chain that would destroy the Papacy, put an end to the Turkish menace, destroy Judaism as a false religion, and result in the triumph of Puritanism. For Mather then, Jews represented the "bait" in Augustine's mousetrap analogy that would catch unrepentant Englishmen once the chain of events unfolded. Given Mather's propensity to read events like King Philip's War through the lens of a protestant telos, it is likely that he viewed Indians as God's pawns in this cosmological drama. It is difficult to determine whether or not Mather equated New England's Indian population with Jews as Eliot did. Linda Munk, The Devil's Mousetrap: Redemption \& Colonial American Literature (Oxford: Oxford University Press, 1997), 52-58, 66-69.

${ }^{40}$ Solomon Stoddard, The Tryal of Assurance, Set forth in a Sermon; Preached at Boston upon a Lecture day. July $7^{\text {th }}$. 1698. (Boston, 1698), 1. This is an issue missionaries constantly faced regarding interpretations of indigenous Christians.

${ }^{41}$ Ibid., 2-5.
} 
to uphold the importance of ministers in examining those who owned the covenant, and Stoddard fell back on the necessity of individual conscience and the inability of any man to truly know the inner workings of another. ${ }^{42}$

Stoddard continued to refine his thinking on the issues surrounding election and published his conclusions in The Inexcusableness of Neglecting the Worship of God (1708), which served as the touchstone for debates on the role of ministers, sacraments, and worshippers within the colony's ecclesiastical practices. ${ }^{43}$ Stoddard prefaced his text by laying out the vision of a never-ending Reformation constantly beset by corruption, for even Luther fell into "that corruption Opinion of Consubstantiation," and the notion that departing from the New England Way might "be a vertue, and an eminent act of Obedience."44 The implications in Stoddard's writings for Indians presumed to be unconverted were significant, as Stoddard culled the Bible for examples where the unconverted participated in religious activities, highlighting the Passover story in the Book of Exodus as an act that everybody took part in, and prayer as an activity that even the ungodly betake in hopes of receiving an answer from God. ${ }^{45}$ Stoddard also argued that the two central sacraments of puritanism - baptism and the Lord's Supper - were both important components on the road to salvation and the unregenerate should make use of them on their path to salvation, contra orthodox puritan beliefs. By this line of reasoning, the baptismal font and the communion table should be open to all, for "there is no certain knowledge who have Sanctifying

\footnotetext{
42 Ibid., 13-14.

${ }^{43}$ E. Brooks Holifield argues against the notion that Stoddard was an innovator, highlighting instead his connection to sacramental debates in England and on the Continent and the "cosmopolitan character of Puritan concerns" in his day. E. Brooks Holifield, "The Intellectual Sources of Stoddardeanism," The New England Quarterly 45 (1972): 392.

${ }^{44}$ Solomon Stoddard, The Inexcusableness of Neglecting the Worship of God, Under A Pretence of being in an Unconverted Condition. Shewed in a Sermon Preached at Northampton, The $17^{\text {th }}$ Decemb. 1707. being the time of the Sitting of the Inferiour Court (Boston, 1708), i-ii.

${ }^{45}$ Ibid., 3-5. Stoddard continued to highlight the central point of his tract: that the ungodly must attend the Sabbath because there is no other way to hear the word and experience conversion. Likewise, Stoddard declared that "it is lawful to Preach the word of God to the Heathen," if not an obligation (5).
} 
Grace." Rather than avoiding the sacrament out of spite, neglect, or fear, Stoddard stated that 'those that are not Scandalous may partake of it, tho' they are not Regenerate. Such persons as might lawfully come to the Passover, may also if they have Knowledge to discern the Lordsbody, lawfully come to the Lords-Supper." ${ }^{\prime 46}$ The lynchpin of Stoddard's argument revolved around the personage of Judas in the gospels, for Jesus baptized him alongside all of the others, sent him to preach, and invited him to the Last Supper when he instituted the sacrament of communion. The fact that the paramount villain of the gospels partook in all of these ordinances served as proof to Stoddard that they be open to all, which held radical implications for inviting Indians into congregations as fellow communicants since all men functioned on the same footing regarding election.

Shortly after Stoddard published his pamphlet, Increase Mather fired back with a lengthy attempt to refute him, arguing that the founding generation of puritans - the Cottons and Eliots would be grieved to see a sermon such as Stoddard's printed in New England. Mather continued to maintain a high view of communion, arguing that the unconverted be barred from the ordinance as "bold Intruders" to a wedding feast. Mather warned that "the Lord will Condemn those men who come into his Church, and so to his Holy Table without true Faith and Holiness," and lamented that Stoddard's suggestions appeared an inversion of nature. ${ }^{47}$ Stoddard retorted in An Appeal to the Learned (1709) that Mather exaggerated their difference of opinion, and agreed

\footnotetext{
${ }^{46}$ Ibid., 11, 14, 18-19. While Stoddard clearly saw certain actions as necessary steps towards conversion, he rejected the preparationist model advocated by Edward Taylor because it cut against the divine mystery of conversion morphology and seemed too much like Arminianism. David L. Parker argues that both Stoddard and Taylor were responding to the paradoxical issues within Congregationalism, though they arrived at separate conclusions: Taylor redefined the entire preparatory process as efficacious, while Stoddard did away with the high model of sacramental admission. David L. Parker, "Edward Taylor's Preparationism: A New Perspective on the Taylor-Stoddard Controversy," Early American Literature 11 (1976): 260-61, 273-74.

${ }^{47}$ Increase Mather, A Dissertation, Wherein The Strange Doctrine Lately Published in a Sermon, The Tendency of which, is, to Encourage Unsanctified Persons (while such) to Approach the Holy Table of the Lord, is Examined and Confuted. With an Appendix, Shewing What Scripture Ground there is to Hope, that within a very few years there will be a Glorious Reformation of the Church throughout the World (Boston, 1708), iv-v, 4-5, 18-19.
} 
that ministers should disbar those who were obviously in an unregenerate and hostile state from communion until they repented. He continued to assert that excommunication was a last resort for those who were persistently obstinate and unrepentant. In his defense, he also warned Mather that the accusation of heresy was a cheap tactic to scare people and immediately put them off to his ideas, and that Mather held the founding puritans in such high regard "as if they were but one degree beneath the Apostles. ${ }^{" 48}$ Reiterating that no minister may aptly claim to know with absolute certainty the spiritual state of any other man, Stoddard agreed that the church should consist of visible saints - to him this meant those who maintained a general intent to follow God as evidenced by their works - leaving knowledge of one's inner state between that person and God. ${ }^{49}$ Though Stoddard's ideas failed to immediately change the landscape of religious practice and colonial theology, the central role of individual conscience in Stoddard's conception of the process of salvation and sanctification contributed to the revivalism of later decades. ${ }^{50}$ At the same time, Experience Mayhew recognized the potential benefits of Stoddard's ideas and promoted them in his own writings, framing them in the context of colonial missions and their applicability to Indian Christians based on his observations of the Wampanoag.

The journals of Longmeadow, Massachusetts minister Stephen Williams also demonstrate the early influence of Stoddard's theology in relation to Native Americans. Williams traveled to Northampton on February 3, 1716 to hear Stoddard preach "upon this doct.

\footnotetext{
${ }^{48}$ Solomon Stoddard, An Appeal to the Learned. Being A Vindication of the Right of Visible Saints to the Lords Supper, Though they be destitute of a Saving Work of God's Spirit on their Hearts: Against the Exceptions of Mr. Increase Mather. (Boston, 1709), i, 2-3, 18-19. Philip F. Gura highlights this as a key aspect of flexibility in Stoddard's thinking, for he was far more willing to critically evaluate the Cambridge Platform and Congregationalism's emphasis on the church covenant for their biblical shortcomings. Stoddard thus recognized the dynamic nature of past practices and the tendency towards corruption, where the Mathers held to a declensionist reading of the present as degeneration from earlier piety. Philip F. Gura, "Solomon Stoddard's Irreverent Way," Early American Literature 21 (1986): 39-40.

${ }^{49}$ This point is emphasized as Stoddard's key innovation in Robert Lee Stuart, “'Mr. Stoddard's Way': Church and Sacraments in Northampton," American Quarterly 24 (1972): 245.

${ }^{50}$ Michael J. Crawford argues that Stoddard dropped a forceful position on communion as a converting ordinance by 1710, but that by the 1720s many New England ministers had adopted aspects of pietistic and Christocentric theology. Crawford, Seasons of Grace, 65-66.
} 
Viz. that tis no benefit unto ungodly men to have their lives continued to them but only upon this account that there is some hopes they may repent." ${ }^{, 51}$ Williams later maintained a continued interest and supporting role to Indian missionaries John Sergeant, David Brainerd, and John Brainerd. The fact that Indians maintained a continual presence within the colony throughout Williams' life suggests that Stoddard's theology greatly shaped his own ministry based on further diary entries. On October 11, 1716 Williams noted that he was reading Stoddard's $A$ Guide To Christ (1714) and he prayed that "god would help me to Guide souls, that I may comfort or benefit when I should," and Stoddard gave the final charge to Williams at his ordination as a minister the very next week. ${ }^{52}$ Shortly after beginning his ministry at Longmeadow, Williams recorded that "There was an Indian woman with us this day [Nov. 1, 1716] desiring to join the church. God favours the heart." Indian participation still created anxiety for Williams though, as "the woman was not Experienced at worship," yet he continued: "I can't be satisfyed that such should be kept from that ordinance. I need God's instruction. Oh Lord direct me and cause there may be a concernedness about Eternal things." During the next two years in his diary Williams recorded his attendance at more sermons by Stoddard and maintained an interest in helping nearby Indians. ${ }^{53}$

Years later Experience Mayhew echoed Stoddard's emphasis on spiritual levelling and his efforts to promote internal contemplation and soul-searching over external judgment of others in a published sermon entitled All Mankind, by Nature, Equally under Sin (1725), which opened immediately by stating "God is no Respecter of Persons. But all in all nations, stand on one

\footnotetext{
${ }^{51}$ Alexander Medlicott, Jr., The Journals of the Rev. Stephen Williams of Longmeadow, Mass. 1716-1718 (Storrs: University of Connecticut, n.d.), 4-5.

${ }^{52}$ Ibid., 33-34.

${ }^{53}$ Ibid., 37. He recorded that Stoddard preached "an Excellent sermon from Matthew 5:13" at Thomas Cheney's ministerial ordination. (88) Likewise, he recorded on December 31, 1718 that he visited a nearby Indian who was deathly sick, asking God to "have mercy on them and delight in their welfare and bring those poor heathens to a serveing acquaintance with Christ" (179).
} 
common Level before God, both in the Duty and the Privilege of Sanctification: Where there is neither Greek nor Jew, Barbarian, Scythian, Bond nor Free.” Beginning with a context steeped in missionary activity, the introduction by Thomas Foxcroft urged Mayhew's readers to consider God's grace as it related to missions, for God had saved "those (once) forlorn and wretched Heathen, the very Ruins of human Nature. ${ }^{.54}$ Like Stoddard, Mayhew urged readers to temper their pride, which "does very much dispose them to think too highly of themselves, and too meanly of others," for by their shared human nature they are equally sinful. Even favored people like the Jews were equally culpable for sin and deserving of judgement, which Mayhew considered a warning to those prone to passing judgment: "we should have run into the same excesses in our Lives, as they have done, had not the Grace of God restrained us from it," for "we are naturally as bad as the very Devils are." ${ }^{.5}$ Mayhew continued to argue against the exclusivist notion that the colonists maintained a "Monopoly of Religion," as the Pharisees believed in a Jewish context and early Christians similarly argued against the inclusion of gentiles. The historical salvation of heathen Englishmen proved that anybody could among the elect, no matter how sinful or wicked they currently seemed, which held its greatest application in missionary work among the Indians. He argued that hundreds, if not thousands, of Indians were among the elect, as evidenced by their spiritual regeneration: "when it pleaseth God to bless

\footnotetext{
${ }^{54}$ Experience Mayhew, All Mankind, by Nature, Equally under Sin. A Sermon Preach'd at The Public Lecture in Boston. On Thursday, Dec. 3. 1724. (Boston, 1725), i-ii.

${ }^{55}$ Ibid., 1-3, 8-19. In an earlier sermon entitled A Discourse Shewing that God Dealeth with Men As with Reasonable Creatures (1720), Mayhew focuses on human relationships in the context of God's treatment of humans. The kindness of God's actions towards mankind following the Fall in Genesis was proof of his exceeding mercy to Mayhew, which he thought should be reflected in human relationships. Reason and conscience should triumph over the use of force, according to Mayhew, and people should be mindful of those in "Gross ignorance" and avoid "Strong Prejudices" against them. Experience Mayhew, A Discourse Shewing that God Dealeth with Men As with Reasonable Creatures In a Sermon Preach'd at Boston, N.E. Nov. 23. 1718. With a brief account of the State of the Indians on Martha's Vineyard, \& the Small Islands adjacent in Dukes County, from the Year 1694 to 1720 (Boston, 1720), 1, 20-27.
} 
means for their good, they are the same effects produced thereby, as the same means do produce on others." ${ }^{, 56}$

Spiritual equality in a sinful nature placed Englishmen and Indians on the same metaphysical footing and served to humble Englishmen who sought to draw artificial distinctions between themselves and their Indian neighbors to missionaries like Mayhew. It also served as a baseline from which to measure the tangible effects of spiritual regeneration in Indians. In that vein, Mayhew continued to expand on Stoddard's sacramental ideas in A Right to the Lord's Supper Considered (1741), which similarly affirms the notion of gradual sanctification and the importance of sacraments as converting ordinances. Mayhew initially affirmed that God commanded his followers to take communion, and that doubts regarding one's spiritual state were sufficient reason to personally abstain from the sacrament. ${ }^{57}$ Examining in detail the nature of the hopeful unregenerate, Mayhew extended Stoddard's thinking, arguing that people who were heartfelt in professing their Christian faith should be called disciples and admitted to communion even though they had not yet experienced regeneration and conversion. Writing in the context of the growing revivals, Mayhew wrote that "awakened Souls, under such a Work of common Grace, stand in great Need of all the Helps God offers them, to excite and engage them to flee unto Christ," as he was persuaded "that the Sacrament of the Lord's Supper is one of those Helps." ${ }^{58}$ Mayhew thus affirmed Stoddard's central ideas while advocating that Indian

\footnotetext{
${ }^{56}$ Mayhew, All Mankind, by Nature, Equally under Sin, 22-25.Laura Arnold Leibman considers Mayhew to be a "Regular Light" who upheld Calvinist orthodoxy while innovating in some areas, particularly in his use of Indian biographies within Indian Converts. Within this section I demonstrate that Mayhew proved more open to Stoddard's ideas than Leibman is willing to acknowledge. Leibman, "Introduction," in Experience Mayhew's Indian Converts, 3-4, 11.

${ }^{57} \mathrm{He}$ also affirmed the position that those living in a clearly unregenerate or unrepentant state should explicitly abstain from communion, and that the Catholic practice of reserving the cup for priests is wrong. Experience Mayhew, A Right to the Lord's Supper Considered in A Letter to A serious Enquirer after Truth. By A Lover of the same. (Boston, 1741), 2-4, 8-12.

${ }^{58}$ Ibid., 14-19. Mayhew understood "common grace" to be the grace extended to all men after Jesus's blood atonement for the separation caused by the Fall in Genesis. Man's sinful state prevented him from ever truly
} 
Christians were true believers to be welcomed into ecclesiastical brotherhood, for their scriptures use the name "Christian" indiscriminately for all those who profess a desire to follow Christ, not to those who prove their regeneration. Relying again on the paramount ruling of individual conscience, Mayhew concludes that "whether [a person is] converted or not, they themselves are the most proper Judges, and ought daily to examine themselves, and prove their own Hearts and Works." ${ }^{59}$

It is no wonder why Mayhew embraced this aspect of Stoddard's theology, as it offered a potent defense of missionary work in its encouragement of self-focus and a positive outlook towards others. By hoping for the best when evaluating the spiritual state of other people, Mayhew advocated ecclesiastical practices that were open to all and eschewed judgment unless there were manifest signs of a person's unregenerate state. This is a marked departure from the prevailing orthodox outlook on missions, which admitted that some Indians experienced sanctification and were among the elect, yet maintained a relatively dim view of Indian potential. In his appendix to a treatise on the importance of doing good entitled Bonifacius (1710), Cotton Mather reprinted the 1705 report on the colony's missionary work to refute "some odd Insinuations made by some who express a Zeal for, The Propagation of Religion, as if nothing had been done that way," though he added an important ending to the letter not found in the original. Mather considered it "an amiable and admirable Spectacle" to see "such forlorn Salvages, and the most ruteful Ruines of Mankind, not only cicurated into some Civility, but also Elevated unto so much knowledge and Practice of Christianity." If Mather seems to offer a dim

approaching God, so when Jesus died it was for everyone in a general sense. He rejected the notion that this was for everyone, otherwise there would be people who went to Heaven and Hell undeservedly. With that in mind, he argued that God gave a special kind of "saving grace" to the elect, and that this would be known through the transformation of one's life at the moment of justification. Experience Mayhew, A Letter To a Gentleman On that Question, Whether Saving Grace be different in Species from Common Grace, or in Degree only? (Boston, 1747), 613, 18-25.

${ }^{59}$ Mayhew, A Right to the Lord's Supper, 29. 
but hopeful view of Indian progress to date, he concluded that the present goal of the New England commissioners was "to Preserve and Improve the Christianity already Professed among them, and Prevent the loss of a Noble Work by some Degeneracies, which have no very well boding Aspect upon it." To Mather, the profligate issue of alcoholism suggested that Indian engagement with Christianity lacked the surety and visible conversion orthodox ministers expected. $^{60}$

It is difficult to determine how Indians who read or listened to Cotton Mather's texts directed to them might have responded, though it is exceedingly probable that the reaction was negative given the venom Mather sometimes brought to them. In an epistle printed in both English and Algonquian in 1700 and 1705, Mather stressed to his Indian audience the wonderful promise of salvation extended by God and the benevolence of the English who spent great time and money in an effort to save them from the "Darkness, and madness, while you lived."61

Mather reiterated the importance of the covenant extended to them and reminded his audience to reflect on their neighbors who "are destroyed by the Dreadful Judgements of God, just as one would Burn up the Trees in the Wilderness" when they refuse it. He then advocated obedience to God in the form of keeping the Ten Commandments, avoiding drunkenness, and practicing English farming and animal husbandry. He concluded with a warning that those who took communion and continued to sin without repentance "shall utterly Perish. God will kill you, with

\footnotetext{
${ }^{60}$ Cotton Mather, Bonifacius. An Essay Upon the Good, that is to be Devised and Designed, By Those Who Desire to Answer the Great End of Life, and to Do Good While they Live. A Book Offered, First, in General, unto all Christians, in a Personal Capacity, or in a Relative. Then more Particularly, Unto Magistrates, unto Ministers, unto Physicians, unto Lawyers, unto Scholemasters, unto Wealthy Gentlemen, unto several Sorts of Officers, unto Churches, and unto all Societies of a Religious Character and Intention With Humble Proposals, of Unexceptional Methods, to Do Good in the World. (Boston, 1710), 194-97. Another representative editorial change that highlights Mather's divergence from his father's view of Indians to a more negative slant is his portrayal of King Philip's war as a holy response to heathen behavior: "The Wars which after an Offered and Rejected Gospel, they perfidiously began upon the English..." (195)

${ }^{61}$ Cotton Mather, An Epistle to the Christian Indians, Giving them A Short Account, of what the English Desire them to Know and to Do, In order to their Happiness. Written by an English Minister, at the Desire of an English Magistrate, who sends unto them this Token of Love (Boston, 1706), 2-3.
} 
one Thunderstroke of His wrath after another. And in Hell, you shall cry out, I am Tormented! I am tormented! for more years, than you now see Leaves upon the Trees." ${ }^{2}$ Mather worried that the unique position Indian Christians found themselves in as people who had historically expressed interest in Christianity would be squandered to their ruin if they did not take more stringent measures to become like the English.

Finally, two comparable texts on missionary work by Cotton Mather and Solomon Stoddard reveal the extent of this divergence in colonial religious thought. In a discourse entitled India Christiana (1721), which he composed when Robert Ashurst became governor of the English company, Mather likened the spread of the gospel in America to the sounding of a trumpet which awakened the elect from their sleep. Dividing those who hear this trumpet call into a number of categories which reflect their engagement with the gospel message, Mather concluded that America's population likely descended from those who rejected the gospel when the disciples preached in the West after Jesus's ascension. In rejecting this message, God "ordered their coming hither as into a Banishment, where they that would not be Saints, do now almost cease to be Men." Though he admitted that "our Indians are generally become such as we must call our Christian Brethren," as evidenced by the piety they displayed to English observers, Mather's tone and frequent use of phrases like "Miserable Animals" and "other wild Creatures" reflects the pervasiveness of his narrow view. While rejecting all Indians outright would negate the effectiveness of missionary work to date - a point Mather was loath to concede in his veneration of the colony's founders - he begrudgingly admitted Indian Christians into the

\footnotetext{
${ }^{62}$ Ibid., 7-14. Mather also had a short text translated into an Iroquoian dialect (most likely Mohawk) for English merchants to use in order to convert Indians to Protestantism in the face of French Catholic proselytization. Cotton Mather, Another Tongue brought in, to Confess the Great Saviour of the World. Or, Some Communications of Christianity, Put into a Tongue used among the Iroquois Indians, in America. And, Put into the Hands of the English and Dutch Traders: To accommodate the Great Intention of Communicating the Christian Religion, unto the Salvages, among whom they may find any thing of this Language to be Intelligible (Boston, 1707).
} 
ecclesiastical community of the colony, but in a subordinate and highly-scrutinized position evidenced in his earlier epistles. ${ }^{63}$

Where Mather relied on the notion that most Indians had rejected the gospel sometime in the distant past and faced their due punishment for it, Stoddard encouraged his readers in Question Whether God is not Angry with the Country for doing so little towards the Conversion of the Indians? (1723) to reflect on God's promise of the conversion of heathens and to remember that no nation enjoyed favor over another. Stoddard singled out disease and war with France as signs that God was mad with the colony for not fulfilling their duty to bring the gospel, and urged his readers to contemplate a reversal of roles with Indians: "And as we dread to go to Hell our selves, it should be awful to us to consider their Damnation... Tho they be Brutish Persons; yet, they are of Mankind, and so objects of Compassion." ${ }^{\text {"64 }}$ Stoddard saw the relationship between colonists and Indians as linked, potentially mirroring the behavior that Paul hoped for in the Jews when he believed that the conversion of gentiles would spur them to emulation. He wrote: "But if the Indians were prevailed with to receive the Gospel, it is hopeful, their Zeal may provoke us... Its hopeful, if Religion should prevail among them, it may be a [illegible] to Revive it among us." While ministers like Cotton Mather reveled in war with their

\footnotetext{
${ }^{63}$ Cotton Mather, India Christiana. A Discourse, Delivered unto the Commissioners, For The Propagation of the Gospel among the American Indians Which Is Accompanied with several Instruments relating to the Glorious Design of Propagating our Holy Religion, in the Eastern as well as the Western, Indies. An Entertainment which they that are Waiting for the Kingdom of God will receive as Good News from a far Country. (Boston, 1721), 4-18, 22-25, 29, 37-38. Similarly, a circular letter signed by Samuel Sewall on behalf of the CPG sent to Josiah Cotton praised the project despite the substantial cost of the endeavor and the great need of schools and catechism to help inoculate Indians against the influence of bad Englishmen. Letter, "Commissioners of the Company for Propagating the Gospel to Josiah Cotton, Feb. 10, 1712/13," Ms. 181, Edward Ayer Collection, Newberry Library.

${ }^{64}$ Solomon Stoddard, Question Whether God is not Angry with the Country for doing so little towards the Conversion of the Indians? (Boston, 1723), 3-6, 8. Laura M. Stevens' study of compassion in British missionary work during this period notes that the portrayal of Indians as gentiles "softened this inimical vision [of Indians as heathens or Canaanites] with a looser allegorical frame and a stronger hope for conversion." Though "a belief that Indians had, through their own fault, lost God's favor held sway throughout the eighteenth century," the deistic attack on God's fairness and criticism of Indian destruction led Christian intellectual to posit new "theories of compassion and universal benevolence" in response. Laura M. Stevens, The Poor Indians: British Missionaries, Native Americans, and Colonial Sensibility (Philadelphia: University of Pennsylvania Press, 2004), 119, 123.
} 
Indian enemies, Stoddard argued that greater measures to convert them were superior to the practices of those who "meditate nothing but utter Destruction." ${ }^{\text {" }} 5$ Stoddard's revisionist reading of New England's ecclesiastical history extended beyond issues of church organization, ministerial authority, and sacramental observance to missionary activity and the conceptual place of Indians within a shared spiritual community, which served as an important intellectual and theological foundation for the pietistic revivals promoted by his grandson Jonathan Edwards and other ministers who began a new wave of evangelical contact with Native Americans.

\section{Revivalism and Indian Christians, 1735-1750}

Religious renewal and recommitment occur from generation to generation in various religions, as a renewed sense of piety often appears necessary when people face newfound pressures and issues. In that sense, the small string of transatlantic evangelical revivals characterized somewhat inappropriately as a "Great Awakening" represented less of a profound break from the past than the proponents of revivalism liked to admit. ${ }^{66}$ After Jonathan Edwards preached a revival message with some success in Northampton in 1735, George Whitefield visited Georgia in 1738 and returned again in 1739 to launch a flurry of controversy as his dramatic sermon style and use of outdoor meetings helped instigate a burst of itinerancy from ministers and laymen who crossed parish boundaries and preached throughout the colonies. Aiding revivalists of both the established and itinerant variety were the various transatlantic texts

\footnotetext{
${ }^{65}$ Stoddard, Question Whether God is not Angry, 11-12.

${ }^{66}$ Lambert, Inventing the "Great Awakening," 22-29, 126-50. Lambert contends that revivals were frequently uneven and localized in their progression, and developed in cultures that recognized their need or potential. English Puritans subsequently injected an evangelical impetus into Calvinism while wrestling with questions of salvation and assurance. Whitefield, for example, considered it important to preach Christianity as the means by which people would hear the gospel and be converted by God. Lambert, "Pedlar in Divinity," 227. Historians now see an interlocking web of ideas shared between Continental pietists in Germany, Welsh and English evangelicals, and New England ministers spanning the transatlantic world. David Ceri Jones, "A Glorious Work in the World”: Welsh Methodism and the International Evangelical Revival, 1735-1750 (Cardiff: University of Wales Press, 2004), 14-19.
} 
promoting the movement, such as Jonathan Edwards' 1735 A Faithful Narrative of the

Surprising Work of God and George Whitefield's Journals. ${ }^{67}$ Though colonists frequently

characterized the Indian presence within the colonies as vanishing, they continued to trade at markets, serve on ships, and socialize with Englishmen and women in nearby towns, which informed them that something was amiss within English society. Linford D. Fisher points to the "carnivalesque environment with reversals and opportunities in abundance as well as a vivid demonstration of the experiential reality of the English God" as a catalyst for Indian participation in revivalism, along with the attention paid to them by New Light ministers, opportunities for education, and the boisterous hymnody of the revivals. He also concludes that "clearly something in their presentation of this version of Christianity struck a chord with many Indian listeners." ${ }^{98}$ Examining the writings of New England ministers newly engaged with proselytization among Indians in the colony illuminates the potential religious draw of revivalism in an indigenous context.

The Mahican Indians of the Housatonic Valley had sought out the help of English neighbors prior to the spread of revivals, as a February letter dictated by the sachem Konkapot to Nehemiah Bull in 1734 mentioned the spread of both disease epidemics and drunkenness within his community, which he feared was the result of some poison used against them by another group of Indians. In the letter Konkapot also fretted about a recent treaty brokered by whites and Mahican leaders they plied with liquor. During an August meeting that same year, the CPG

\footnotetext{
${ }^{67}$ Kidd, The Great Awakening, 5-13. Lambert, "Pedlar in Divinity, ” 7-8, 170, 200-03.

${ }^{68}$ Fisher, The Indian Great Awakening, 65-71. Fisher also makes two other important points: first, he argues that revivalism must be understood in a context where Indian and English communities were inexorably linked under colonialism, and second, that revivalism was rarely a "sudden intrusion of Christian ideas into the lives of Natives nor a reversal of former disinterest in Christianity. Rather, it was a fairly natural extension of two full decades of Native individuals and communities engaging with Christian ministers, educators, ideas, and practices" (71, 83). Kathleen Bragdon observes that native practices of oratory, emotion, and lamentation created a kind of Native Christianity that anticipated English revivals and served as a fitting complement to new English religious expression. Bragdon, Native People of Southern New England, 1650-1775, 180.
} 
noted a report authored by Bull and Stephen Williams describing their visit with the Housatonic Indians and the decision to send a dedicated minister to live with them, tasking the Englishmen to find a minister suitable for the project. ${ }^{69}$ Bull and Williams settled on John Sergeant, who had enrolled at Yale when he was fifteen in 1725 and graduated valedictorian in 1729. Sergeant received a second degree in theology in 1732 and had expressed some interest to Samuel Hopkins regarding work with the Indians rather than an English church. ${ }^{70}$ Sergeant began his ministry with the Housatonic group in 1734, and became sufficiently adept at understanding Indian customs to write a letter in 1739 to Stephen Williams describing the nuances of Indian diplomacy when Annauwauneekheek, a Christian Indian and “one of our Communion” delivered wampum on behalf of a community at Mkhauwaumuk, some 200 miles west of them. The Indians at Mkhauwaumuk stressed in their message that they sought to purge drinking from their community and that they agreed to "trade no more in Rum and that they have actually broken some kegs (caqqs) which the Traders have brought to them."71

It is likely that Indians saw spiritual power in the emotional side of revivalism that might enable them to purge alcohol from their communities. In the instances where he described indigenous conversion or affiliation with Christianity, Sergeant frequently prefaced his affirmation of the outward signs of transformation with a statement of drunkenness turning into temperance, as "nothing but the extraordinary power that attended Christianity in its first

\footnotetext{
${ }^{69}$ Letter, "Chief Konkapot to Nehemiah Bull, Feb 5, 1734/5," Ms. 205, Edward Ayer Collection, Newberry Library. Letter, "Adam Winthrop on behalf of the Commissioners for the Indian Affairs in Boston, Aug. 16, 1734," Ms. 570, Edward Ayer Collection, Newberry Library. Peter C. Mancall's assessment of alcohol consumption in the Great Lakes region during the early American republic found that drunkenness crossed gender and age boundaries due to the ubiquity of the colonial alcohol trade. It was not until the period of American nationalism that a unified government body attempted to curb consumption and trade with Indians throughout the continent. Peter C. Mancall, "Men, Women, and Alcohol in Indian Villages in the Great Lakes Region in the Early Republic," Journal of the Early Republic 15 (1995): 425-27.

${ }^{70}$ Samuel Hopkins, Historical Memoirs, Relating to the Housatonic Indians By Rev. Samuel Hopkins (1693-1755) (New York, 1911), 13-19..

${ }^{71}$ Letter, "John Sergeant to Stephen Williams, May 14, 1739," Ms. 800, Edward Ayer Collection, Newberry Library.
} 
propagation will be sufficient to reform them." ${ }^{, 72}$ Throughout his Journal extracts Sergeant observed the temptation to return to drink and the varied successes and failures of his potential converts, as Wnampee “told the Indians at Hudson's River plainly, that he designed to go to Heaven, and therefore must leave off such wickedness" when he was offered alcohol. Similarly, when he baptized Wautaunkumeet and his children Stoddard stressed his reform from drinking. ${ }^{73}$ Harnessing spiritual power or manitou to purge damaging activities such as the excessive consumption of alcohol appears to be a significant factor guiding Indian efforts to engage Sergeant and found the Stockbridge mission, in addition to the security gained by the legal recognition of lands and the connections Sergeant and transatlantic missionary societies brought.

In evaluating Indian society and offering his general thoughts to Williams, Sergeant wrote that they were "poor aboriginal natives, who, as they seemed to have been in a great measure abandoned by Heaven so they have been and are treated with too much neglect by us who, in Grace alone has made to differ from them." While continuing to promulgate the notion that Indians were spurned by God for some sort of gross misdeed or rejection of the gospel in the ephemeral past, Sergeant stressed that the only distinction between them was a state of salvation and that "it very ill becomes us therefore to set ourselves against them but rather to fear for ourselves and pray for them." ${ }^{.74}$ In his dialogues with Indian sachems, Sergeant recognized that "the Indians generally own the difference between moral good and evil, as also a future state of rewards and punishments," and that some aspects of culture might be morally neutral. In one such instance, the Stockbridge community asked Sergeant if they could continue to act out a mourning dance called the keutikau, which they assured him held no latent spiritual significance

\footnotetext{
${ }^{72}$ Hopkins, Historical Memoirs, 32.

${ }^{73}$ Ibid., 43, 73. Further in his writings Sergeant noted that English observers took note of the temperance movement embraced by the Stockbridge community and that the resolution to purge drinking was widespread despite a few relapses (49).

${ }^{74}$ Letter, "Sergeant to Williams," Ms. 800.
} 
but had incorporated alcohol in the past. So long as they abstained from drinking, Sergeant could discern no harm in the activity. ${ }^{75}$ In his descriptions of baptism, Sergeant betrayed an adherence to sacramental practices informed by the idea of baptism as a converting ordinance:

I have baptiz'd almost forty persons, infants and adult. I hope the adult have a pretty good understanding of the main and fundamental doctrines of the holy religion into which they have been baptiz'd. And I always endeavoured to possess their minds with the most serious sense of what they were about when they enter'd themselves the disciples of Christ. Their whole hearts seem'd to be engaged in the matter, and I have reason to think that the imperfection of their knowledge is made up by their zeal and integrity. ${ }^{76}$

Though he occasionally deferred baptism to a later date when he was unsure of a subject's doctrinal knowledge and sincerity, Sergeant relied on outward signs of reformation as signals of an inward change that he could only imperfectly plumb. In the end, he hoped for the best: a sentiment expressed by David Brainerd in his own sacramental administrations as a missionary. Promoting both his missionary work and a defense of revivalism, Jonathan Edwards' publication of the private diary and public journal of David Brainerd offers the best case study of revivalism's theological appeal to Indians as well as the missionary's personal musings and thoughts while he lived with Indians in Pennsylvania, Massachusetts, and New Jersey. ${ }^{77}$ While a student at Yale, Brainerd joined the revivalist camp and faced dismissal from his studies after quarrelling with the college's faculty in 1741 . Without the credentials to serve as an ordained minister with an English parish, Brainerd turned to missionary work and pursued an appointment

\footnotetext{
${ }^{75}$ Hopkins, Historical Memoirs, 47-48. Despite their assurances, it is difficult to accept that this dance held no religious significance.

${ }^{76}$ Ibid., 53. Later he wrote that he was surprised at the speed and nature of reform, and that "their hearts seem really to be engag'd" in religion (65).

${ }^{77}$ Both Brainerd and Edwards were interested in the empirical evidence of conversion as displayed by Indian religiosity. As such, Brainerd's writings were not those of a detached ethnographer but of one searching for universal truth. Edwards' editorial glosses sought to highlight the "mutually dependent relationship between the evidence of the minister's soul and the evidence of God's presence among his flock." Rivett, Science of the Soul, 277-78, 337-38.
} 
in that capacity. ${ }^{78}$ Brainerd frequently vacillated between spiritual highs and lows in his private diary - a point which Edwards sought to judiciously edit out when Brainerd became too despairing in his writings - frequently demeaning himself by stating that he was "mean and vile," enslaved by "the dreadful sin of [his] nature," and "very vile and worthless.."79 Brainerd often reflected on the sovereign nature of God's wrath and punishment in contrast to the undeserved nature of his grace - standard and weighty aspects of puritan theology - in relation to his position as an individual saved by God in contrast to Indians, though he frequently deemed himself even worse for his spiritual failings:

I scarce ever felt myself so unfit to exist as now: saw I was not worthy of a place among the Indians, where I am going, if God permit: though I should be ashamed to look them in the face, and much more to have any respect shown me there. Indeed I felt myself banished from the earth, as if all places were too good for such a wretch. I thought I should be ashamed to go among the very savages of Africa; I appeared to myself a creature fit for nothing, neither heaven nor earth. None know, but those who feel it, what the soul endures that is sensibly shut out from the presence of God: alas! it is more bitter than death. ${ }^{80}$

Despite this positive portrayal of Indians in relation to himself, it proved difficult for Brainerd to shake his own cultural favoritism, as he observed "something of flatness and deadness after [he] came there [to Montauk] and had seen the Indians" on his way to Stockbridge when he first began missionary work. ${ }^{81}$ Though extensive sermons and sermon notes do not survive today, the

\footnotetext{
${ }^{78}$ Edwards, ed. The Life and Diary, 24-29. Edwards frequently sought to tone down Brainerd's extremes and offer qualifications for some of his statements in an effort to position Brainerd and his work within the moderate camp. Keeping the criticisms of antirevivalists in mind, Edwards urged readers to conclude that "Mr. Brainerd's religious impressions, views, and affections in their nature were vastly different from enthusiasm; so were their effects in him as contrary to it as possible." When he came to Brainerd's dismissal from Yale, Edwards wrote that he recognized that "his religious experiences and affections at that time were not free from a corrupt mixture, nor his conduct to be acquitted form many things that were imprudent and blameable," and that he had since repented and corrected his thinking and behavior $(7,27)$.

${ }^{79}$ Ibid., 33-34, 43.

${ }^{80}$ Ibid., 69.

${ }^{81}$ Ibid., 73. Brainerd also commented negatively on Indian mortuary rituals, calling them "heathenish practices," which led him to lament their darkness and hope that they would turn to Christianity (121).
} 
overwhelming emphasis on his own worthlessness throughout the Diary proved inescapable for Brainerd and possibly shaped his presentation of particular passages before Indian audiences. In one of his first sermons to a mixed Indian-English crowd on his way to New York for examination before members of the Scottish Society for the Propagation of Christian Knowledge (SSPCK), Brainerd spoke on Job 14:14: "If a man die, shall he live again? All the days of mine appointed time will I wait, till my changing shall come.” He appears to have preached extemporaneously, as no published sermon or notes remain, but the potential for spiritual renewal, resurrection, and the promise of future change at the hands of a divine and powerful being are apparent in the selection of this text. He observed that "Some Indians cried out in great distress, and all appeared greatly concerned" upon hearing the sermon. ${ }^{82}$ In his initial work at Kaunaumeek Brainerd relied on an Indian translator named John Wauwaumpequnaunt, who trained under John Sergeant in the basic doctrine of Christianity and lived for a time with Stephen Williams where he received further instruction and "wrote a good hand." ${ }^{\prime 3}$ Once he began his second mission among Delaware Indians he preached on turning away from "all the vanities of the heathen," which presumably included forsaking certain practices in favor of what Indians might view as a more ascetic and spiritually powerful lifestyle, which greatly affected

\footnotetext{
${ }^{82}$ Ibid., 50. TheSSPCK popularized Brainerd's work in part because revivalists adopted a millennialism similar to that of Eliot one hundred years earlier. Jonathan Edwards hoped like many before him that the conversion of Indians would trigger a greater cataclysm with the second coming of Christ. Crawford, Seasons of Grace, 232. One sermon attributed to Brainerd survives in the archives at Yale, and John Grigg observes that it stresses God's benevolence and the freedom salvation gave the soul to overcome sin, a concept that clashed with the typical Calvinist conception of God. John Grigg, “'A Principle of Spiritual Life': David Brainerd's Surviving Sermon,” The New England Quarterly 77 (2004): 273, 278-79.

${ }_{83}$ Brainerd, Life and Diary, 82, n2. That winter Brainerd began to study indigenous languages with Sergeant under the direction of the SSPCK (100). Brainerd eventually convinced the Kaunaumeek Indians to join Sergeant and the Stockbridge community, which prompted him to begin a new mission among the Delaware Indians (116). Stephen Williams' support of missionary work is an interesting topic in its own right that deserves future exploration, as he and his family were the famed captives of the 1704 Deerfield raid during Queen Anne's War. The fact that Williams did not emerge from captivity overtly hostile to Native Americans as Mary Rowlandson did is an interesting point of comparison I hope to explore more fully in an unrelated context. For more on the Williams family see John Demos, The Unredeemed Captive: A Family Story From Early America (New York: Vintage Books, 1994).
} 
the Indian crowd and convinced some to attend Brainerd's second sermon to white residents. ${ }^{84}$ After spending a year at the Forks of Delaware with little success, Brainerd journeyed to Crossweeksung, New Jersey where he initially preached only to small crowds of women and children that grew to about thirty curious onlookers in June $1745 .^{85}$

Though it is difficult to determine the exact appeal of the revivalist form of Christianity to Indians who encountered it during this period, Brainerd's Journal provides some clues in this arena. In one passage he described his encounter with "several Indians newly come who thought their state good and themselves happy" because they learned about Christianity while living in white households. Brainerd stated that he "was surprised to see their self-righteous disposition, their strong attachment to the covenant of works for salvation, and the high value they put upon their supposed attainments," arguing against this notion and for the impossible distance between man and God. ${ }^{86}$ In this exchange, Brainerd observed that one of the men broke down into weeping, asking what he could do to attain salvation through his tears. Sermons frequently stressed this point and elicited a similar response from crowds, which suggests that Indians saw in this message of cosmic imbalance the futility of their efforts to attain the sort of equilibrium sought in indigenous cosmologies. Sermons on John 12:44-50, Acts 2:36-39, Acts 16, and John 14:1-6 all drew strong emotive responses from the gathered Indian crowds. Thematically, each sermon addresses aspects of God's judgment against mankind, which Indians could easily read in the tumult of colonialism's long history in the region, and the promise of an end to earthly woes in heaven for those who choose to follow God. ${ }^{87}$

\footnotetext{
${ }^{84}$ Ibid., 129. Brainerd himself often used the terms "Indian" and "white people," reflecting a growing racialized linguistic distinction between Euro-Americans and Indians (131). See also, Kathleen Brown, "Native Americans and early modern concepts of race," in Empire and Others: British Encounters with Indigenous Peoples, 1600-1850, ed. Martin Daunton and Rick Halpern (Philadelphia: University of Pennsylvania Press, 1999), 95-98.

${ }^{85}$ Brainerd, Life and Diary, 271-72.

${ }^{86}$ Ibid., 291.

${ }^{87}$ Ibid., 295, 302-03.
} 
The dissemination of Stoddard's sacramental practices throughout the colonies prior to the growth of revivalism also freed Brainerd from the issues of clerical oversight that John Eliot faced when the Natick church sought covenant status. In July 1746 Brainerd observed that he administered the sacrament to about thirty-one Indians. Upon taking the sacrament, the Indians were "sweetly melted and refreshed, most of them," and simply uncovering the bread and wine caused a similar reaction, which Brainerd took as a sign of both Indian understanding of the significance of the ritual and devotion to religion. ${ }^{88} \mathrm{~A}$ few months later he administered the sacrament again to forty Indians and an unnumbered amount of Englishmen who were gathered as well, which encouraged Brainerd as he witnessed "the sweet union and harmony then appearing among the religious people!" ${ }^{89}$ Similarly, in July 1745 Brainerd noted in his Journal that he baptized the interpreter he had worked with since the summer of 1744, Moses Tindatautommi and his wife, and that "they are both persons of some experimental knowledge in religion; have both been awakened to the solemn concern for their souls... and it is apparent both have passed a great, and I cannot but hope a saving, change. ${ }^{~}{ }^{90}$ Here Brainerd distinguishes between the common grace that he observed in Moses and his wife and the saving grace that only Moses himself could verify as proof of his status among the elect, yet Brainerd did not fret about baptizing them in vain. Instead, it is clear that he adopted Stoddard and Mayhew's admonitions to leave the final verdict to God in the hopes that baptism, instruction, and

\footnotetext{
${ }^{88}$ Ibid., 203.

${ }^{89}$ Ibid., 223. The sermon text preached by Brainerd was John 1:29: "The next day John seeth Jesus coming unto him , and saith, Behold that Lamb of God, which taketh away the sin of the world." Given the causal understanding of sin and its effects on a person's life, this may have resonated with Indians as a call to follow the religion and to receive in return a reprieve from their temporal sufferings. In a few of his Journal entries, Brainerd denoted the interactions of white observers and Indians. In one instance he stated that a crowd of whites "came out of curiosity to 'hear what this babbler would say' to the poor ignorant Indians," and were "much awakened, and some appeared to be wounded with a view of their perishing state." At another gathering he addressed both Indians and Englishmen in a sermon on Acts 2 that greatly impacted the gathered crowd. He wrote that "several of the white heathen were awakened," which conflated Englishmen with Indians in an atypical way $(284,287)$.

${ }^{90}$ Ibid., 275. Brainerd baptized their children later in the week (279).
} 
communion led the convert on the gradual path to salvation. To justify his actions, Brainerd interrupted his day-to-day account with an extended aside to the character and changes he observed in Moses since they began working together. The next month he baptized fifteen Indian adults and ten children, stating that he had "comfortable reason to hope [they] are renewed persons" despite doubts about a few of them..$^{91}$ As he closed the first part of his Journal, Brainerd reflected that he had baptized forty-seven people in all, and that "through rich grace, none of them as yet have been left to disgrace their profession of Christianity by any scandalous or unbecoming behavior."92

Brainerd also encountered Indians previously exposed to and influenced by other religious traditions, as he noted in his December 22, 1745 entry of his public Journal that some Indians newly arrived at Crossweeksung lived previously with Quakers. Though they were "more civilized and conformed to English manners than the generality of the Indians," Brainerd noted in dismay that they "had imbibed some of the Quakers' errors, especially this fundamental one, viz. That if men will but live soberly and honestly, according to the dictates of their own consciences, (or the light within), there is then no danger or doubt of their salvation." He considered these Indians to be "much worse to deal with than those who are wholly under pagan darkness, who make no pretenses to knowledge in Christianity at all," as a competing Protestant tradition had already been introduced, forcing Brainerd to confront both Indian traditions and denominationalism in his overtures. ${ }^{93}$ Beyond the particular theology of revivalist puritans like

\footnotetext{
${ }^{91}$ Ibid., 292. He uses similar language to discuss fourteen more Indians baptized later in the year (305).

${ }^{92}$ Ibid., 306-07. Linford D. Fisher argues that indigenous participation proved far more sporadic and tapered off within Pequot communities by 1742, though Indian church membership numbers did show interest which predated the formal spread of revivals. He also observed that interest peaked after Davenport toured the region with his more radical revivalist message. Linford D. Fisher, “It Provd But Temporary, \& Short Lived': Pequot Affiliation in the First Great Awakening," Ethnohistory 59 (2012): 465, 470-78.

${ }^{93}$ Ibid., 321-22. Quakers and German pietists both adhered to the somewhat outdated notion of a universal language that needed to be harmonized in order to join all men together in religious communion. Theorists posited that after the fall at Babel languages were divided like puzzle pieces so that each grouping of people held some aspect of a
} 
Brainerd, it is important to note that other distinct formulations of Christianity such as

Quakerism offered a greater degree of assurance, which may have been more appealing compared to the anxiety contained within puritanism. In the case of Moravian missionaries, Patrick Erben notes that the Moravian emphasis on Christ - particularly his torture and sacrifice - resonated with Indian culture that afforded a great degree of spiritual power to captives who faced torture and death with stoicism. ${ }^{94}$

As a "New Light" minister who embraced the emotive piety of revivalism, Brainerd also recognized the polemical furor of the 1740 s and probably received word of the latest developments in pamphlet wars between men like George Whitefield, Jonathan Edwards, and Charles Chauncey during his frequent visits to English settlements and ministers. The closing pages of the first edition of his Journal offer an extended defense of the veracity of revival among the Indians he encountered and a justification of God's method in inciting revival. In his “General Remarks,” Brainerd downplayed his own role as an "instrument in the saving conversion of any of the Indians, except [his] interpreter and his wife," arguing instead that the only logical explanation for the Indians' response to aspects of his preaching and their weeping at the sight of the Lord's Supper was a spirit of grace generating this emotion. ${ }^{95} \mathrm{He}$ argued that it was in Indian country that the true general awakenings occurred, and that God employed "milder means" of revival, as "there has here been no appearance of those convulsions, bodily agonies, frightful screamings, swoonings, and the like, that have been so much complained of in some places." Furthermore, there were no "mental disorders here, such as visions, trances,

divine, universal truth. This fascination with linguistic corruption served as a touchstone for Quaker and Moravian interest in proselytization in British North America. See Patrick M. Erben, A Harmony of the Spirits: Translation and the Language of Community in Early Pennsylvania (Chapel Hill: University of North Carolina Press, 2012), 1728, 37-46, 303-06.

${ }^{94}$ Ibid., 306.

${ }^{95}$ Edwards, ed., Life and Diary, 307-311. 
imaginations of being under prophetic inspiration, and the like." Instead, he observed moral reform in the rejection of drinking and other orderly behaviors. ${ }^{96}$ By providing a defense at the end of his public account of ministry, Brainerd recognized the contentious place of Indians within the colony as a whole, and particularly in the context of revivalist debates that spanned the decade. By portraying Indian conversion as orthodox, demure, and orderly, he sought to negate common conceptions of Indian behavior and to counter antirevivalist arguments which conflated revivalism with degeneration into the barbarity enjoyed by Indians as "natural men."

\section{Countering Enthusiasm: The Antirevivalist Critique as Indian Behavior and Degeneracy}

Scathing criticism of established ministers and church practices in New England set off a polemical furor as antirevivalists considered attacks by leading revivalists George Whitefield, Gilbert Tennent, and James Davenport on ministers as unconverted or preaching false doctrines to be a threat to the established order of the ecclesiastical body. The participation of laymen and women - some of them Indians or enslaved Africans - and the proliferation of itinerant ministers who crossed parish boundaries and split congregations into factionalism cut against the sensibilities of trained ministers who were ordained and selected by parishioners and synods within the colony. ${ }^{97}$ Equally unnerving and offensive to orthodox Boston ministers like Charles

\footnotetext{
96 Ibid., 312-13.

${ }^{97}$ Hall, Contested Boundaries, 56-7, 134-5. Revivals also promoted religious heterodoxy, especially in the Middle Colonies, though New England ministers proved just as critical of groups like the Moravians. See Jane T. Merritt, "Dreaming of the Savior's Blood: Moravians and the Indian Great Awakening in Pennsylvania," The William and Mary Quarterly 54 (1997): 726, 736. Linford D. Fisher, “'I Believe They are Papists!': Natives, Moravians, and the Politics of Conversion in Eighteenth-Century Connecticut," The New England Quarterly 81 (2008): 410-12, 422-31. Anthony L. Blair, "Shattered and Divided: Itinerancy, Ecclesiology, and Revivalism in the Presbyterian Awakening," The Journal of Presbyterian History 81 (2003): 21-23. Ian M. Randall, “A Missional Spirituality: Moravian Brethren and eighteenth-century English evangelicalism," Transformation 23 (2006): 208-210. Jared S.
} 
Chauncy was the emphasis revivalists placed on emotive, spiritual piety they recognized as supplanting the cerebral, intellectual aspect of the conversionary experience and bolstering the position of ministers as trained authorities on theology. ${ }^{98}$ In their criticisms of revivalist theology and practice, antirevivalists and moderates utilized language and concepts frequently deployed against Native Americans to undercut their opponents' positions, conflating them subconsciously with the degenerate, wild, and lawless behavior they saw in the society and religious practices of unconverted Indians. With this in mind, writers who sought to defend Indian revival consciously sought to differentiate the behavior of Indian converts in contrast with the more extreme aspects of revivalism, tacitly affirming the critique of those most strongly opposed to the religious movement. Analyzed through the lens of colonial culture, the antirevivalist critique reveals a strong fear of degeneracy and disorder which suggests that religious practice and culture served to undergird a growing racialized distinction between Indians and Englishmen, and that revivalist practices sought to collapse this distinction in the minds of the movement's critics.

By this point, the longstanding presence of jeremiad sermons impressed a history of the colony on the minds of many ministers which emphasized the superior piety of the founding generation and the subsequent decline displayed by the general population. ${ }^{99} \mathrm{~A}$ central cultural tension which many colonists fretted upon was the presumed effect that the environment itself

Burkholder, "This 'rends in Pieces all the Barriers between Virtue and Vice': Tennentists, Moravians, and the Antinomian Threat in the Delaware Valley," The Pennsylvania Magazine of History and Biography 135 (2011): 7, 19-20, 26-28.

${ }^{98}$ William Shurtleff's ordination sermon preached at Nathaniel Gookin's commission serves as a representative example of the high view of the ministerial office. Shurtleff likened ministers to stars in the sky in an exposition of Revelation 2:1: "He that holdeth the Seven Stars in his right Hand." In Shurtleff's mind, ministers "shine or shed forth Light upon a dark and benighted World": the source of illumination of God's knowledge that saved mankind from "sadly bewilder'd and perplex'd" darkness until the second coming of Christ. William Shurtleff, Gospel Ministers exhibited under the Notion of Stars; and our Lord Jesus Christ as holding these Stars in his right Hand. In a Sermon Preach'd at the Ordination of Mr. Nathaniel Gookin. To the Pastoral Office of a Church at North-Hill in the Town of Hampton, October 31.1739 (Boston, 1739), 8-10.

${ }^{99}$ This Boston association of clerics also drew on early Enlightenment thought and scientific naturalism, which downplayed the notion of momentous spiritual and supernatural interruptions in the world. Timothy E.W. Gloege, “The Trouble with Christian History: Thomas Prince's Great Awakening," Church History 82 (2013): 129-31. 
possibly had on those who left "civilized" society for a place marked by lesser degrees of civilization. In a May 1743 declaration against the spread of revivalism, a gathering of Boston ministers chose to emphasize the present theological developments as a renewed antinomian attack on the colony which ran counter to the statements of the 1637 Synod. ${ }^{100}$ In his 1745 Tristitiae Ecclesiarum: Or, A brief and sorrowful Account of the Present State of the Churches in New-England, Samuel Niles decried the "Strife and Contention [that has] come upon us like a Flood" and "threatens the overthrow of all Order, and the utter subversion of [the] Gospel Constitution" laid down by "our Fore-fathers, who, under God, planted the Gospel at the Peril of their Lives in this American Wilderness." Niles feared the colony faced a similar fate as "the Jewish Church in her Times of Degeneracy" if itinerancy and revivalist doctrine flourished. ${ }^{101} \mathrm{~A}$ testimony of the Harvard faculty against Whitefield's ministry similarly cited his behavior as leading to "the entire Destruction of the Order of these Churches of Christ... especially as he hath so much of an enthusiastic Turn, utterly inconsistent with the Peace and Order, if not the very Being of these Churches of Christ." ${ }^{102}$ Many ministers in the colony feared the proliferation of ideas which might corrupt their churches, as Edward Holyoke authored an address as the President of Harvard which drew typological analogies between the biblical Pharisee and

\footnotetext{
${ }^{100}$ The Testimony of the Pastors of the Churches in the Province of the Massachusetts-Bay in New-England, at their Annual Convention in Boston, May 25. 1743. Against several Errors in Doctrine, and Disorders in Practice, Which have of late obtained in various Parts of the Land; as drawn up by a Committee chosen by the said Pastors, read and accepted Paragraph by Paragraph, and voted to be sign'd by the Moderator in their Name, and Printed. (Boston, 1743), 6.

${ }^{101}$ Samuel Niles, Tristitiae Ecclesiarum: Or, A brief and sorrowful Account of the Present State of the Churches in New-England: In a Letter From a Minister in the Country to the Publick. Wherein is contained, Some Remarks on the Rise, Progress, and unhappy Effects of the different Sentiments among Us at this Day in Matters of Religion. To which is added by Way of Advice Some healing Measures. With an Appendix (Boston, 1745), 3.

102 The Testimony of the President, Professors, Tutors, and Hebrew Instructor of Harvard College in Cambridge, Against the Reverend Mr. George Whitefield, And his Conduct. (Boston, 1744), 3. A testimony authored by the ministers at Marlborough similarly cited Whitefield as being "so Disorderly in his Conduct" and chided him for encouraging itinerant practices which broke from biblical teaching and the past history of the colony. The Testimony Of an Association of Ministers Convened at Marlborough, Jan. 22. 1744. Against the Reverend Mr. George Whitefield, And his Conduct. As also, The Testimony Of a Number of Ministers in the Country of Bristol, Against the said Gentleman (Boston, 1745), 4.
} 
Sadducee sects to contemporary threats of antinomianism and Arminianism (represented by the Pharisees) and deism and atheism (as a modern day form of the Sadducee sect), urging ministers to guard their churches against internal heresy and outside interference. ${ }^{103}$ John Sergeant assessed contemporary revivalism as a repetition of biblical moments where God allowed a people to fall into error like the Jews of the Old Testament in order to cull the weak and unrighteous through acts of judgment. ${ }^{104}$

This preoccupation with degeneration begs the question of into what exactly antirevivalists feared parishioners and religious practice would degenerate. Longstanding linguistic and cultural speculation on Indian origins suggested a lost Jewish or barbarian past for a people who somehow shunned God and deserved the just punishments of war, disease, and displacement that had shaped much of colonial contact during the previous century. Regardless of their origins, puritan ministers frequently linked their position with God's displeasure and cultural degeneration over an extended period of time. Ministers thus warned that revivalist corruption served as yet another step which threatened to plunge colonists deeper into a barbaric state. In falling away from orthodox practice and doctrine, the colonists might become like their nearest and most tangible "proof” of corruption's effects in their Indian neighbors.

Of all the practices promoted by Whitefield and other revivalists, itinerancy received the most attention from critics because the practice threatened to break down parish boundaries and

\footnotetext{
${ }^{103}$ Edward Holyoke, The Duty of Ministers of the Gospel to guard against the Pharisaism and Sadducism of the present Day. Sherewd in a Sermon Preach'd to the Convention of Ministers of the Province of the MassachusettsBay, N.E. at Boston, ON Thursday, May 28. 1741 (Boston, 1741), 26-32. Laura Stevens argues that SPG sermons delivered in England served as the Church of England's primary means of response to the growing deistic challenges by promoting sensible benevolence as a uniquely Christian virtue, as "Anglicans needed to display their interest in converting Indians so that they could reply to a particularly challenging aspect of Deist thought. They had to undercut the idea of the noble savage promoted by the Deists, and they had to explain why the exclusion of Indians from the awareness of the gospel did not show that Christianity was cruel." Stevens, The Poor Indians, 127-31, 136. ${ }^{104}$ John Sergeant, The Causes and Danger of Delusions In the Affairs of Religion, Consider'd and caution'd against, With particular Reference to the Temper of the present Times. In a Sermon Preach'd at Springfield, April 4. 1743. In the Audience of the associated Pastors of the County of Hampshire (Boston, 1743), 11-13.
} 
allowed untrained laymen to presume equality with ordained ministers. Frequent movement and the severance of communal ties represented a threat similar to indigenous patterns of mobility and community formation and breakdown according to seasons. The May 1743 declaration decried itinerancy as a great disorder which brought "an heinous Invasion of the ministerial Office" by uneducated people "without any regular Call" to preach. ${ }^{105}$ In Tristitiae Ecclesiarum Niles portrayed Itinerants as "enthusiastick and erroneous," describing their proliferation in the wake of sensational revivalists like Whitefield and Davenport as the growth of "tribes of publick Exhorters." He also criticized the breakdown in family government as some men left their wives under the justification that they were unconverted in favor of wives who shared their regenerate convictions: behavior which signified a further degeneration in society which might draw parallels to knowledge of Indian relationship and cohabitation practices. The choice of the word "tribes" to describe the itinerants also suggests a subconscious linkage between the biblical typology of Israel's history, Indians, and mobility. ${ }^{106}$ In Seasonable Thoughts on the State of Religion in New-England (1743), Charles Chauncey criticized itinerants, as they "were idle, not doing their own Business; but wandring about from House to House, talking, and speaking the Things they ought not." This characterization also frequently resurfaced in colonial complaints of Indian mobility and labor practices. ${ }^{107}$ In their criticism of itinerant preaching, the ministers gathered at Barnstable in 1745 rejected the notion that itinerants accurately emulated the Pauline missions to gentiles because Paul and the apostles "usually went to preach to such as sat in heathenish Darkness, or if elsewhere, they were constituted Visitors and Inspectors of the

\footnotetext{
${ }^{105}$ The Testimony... at their Annual Convention in Boston, May 25. 1743, 6-7. A 1745 declaration issued at Barnstable similarly condemned the contention caused by itinerants. The Declaration of Ministers In Barnstable County, relating to the late Practice of Itinerant Preaching (Boston, 1745), 5.

${ }^{106}$ Niles, Tristitiae Ecclesiarum, 4.

${ }^{107}$ Charles Chauncy, Seasonable Thoughts on the State of Religion in New-England, A Treatise in five Parts (Boston, 1743), 42.
} 
Churches.” The suggestions that itinerants would find better work among unchurched

populations on the frontier of English society sought to contain and channel itinerancy. The fact

that Indian lay exhorters were not unheard of also suggests that the efforts to maintain parish

boundaries against itinerancy contained an exclusivist notion informed by the growing racism of the eighteenth century. ${ }^{108}$

Antirevivalists also seized on the behavior of itinerants and the crowds excited by their extemporaneous and vivid preaching, as a 1742 censorship of James Davenport specifically criticized the raucous behavior of his followers as they sang psalms in the streets in addition to the neglect of parish that revivalism caused when Davenport left his church at home to preach in New England. ${ }^{109}$ The 1743 testimony of Boston ministers went even further, declaring:

Though we deny not, that the human Mind, under the Operation of the Divine SPIRIT, may be overborn with Terrors or Joys; yet, the many Confusions that have appeared in some Places, from the Vanity of Mind, and ungoverned Passions of People, either in the Excess of Sorrow or Joy, with the disorderly Tumults and indecent Behaviours of Persons, we judge to be so far from an Indication of the special Presence of GOD with those Preachers that have industriously excited and countenanced them, or in the Assemblies where they prevail, that they are a plain Evidence of the Weakness of human Nature. ${ }^{10}$

\footnotetext{
${ }^{108}$ Declaration of Ministers In Barnstable , 4. In his Meditations on Several Divine Subjects (1748) James Davenport claimed Paul within the revivalist camp using Ephesians 3:19 as his proof-text. He argued that if an intelligent reader laid out Paul's writings and the Book of Acts in comparison to "those [actions] of some late zealous Preachers," they would "say they were both evidently under the Influence of the same Spirit and Principles, both aiming at the same End, and carrying on the same Design, and both acting by the same Rule." James Davenport, Meditations on Several Divine Subjects: I. On the Humanity of CHrist. II. The Extensiveness of God's good Design in Selling Joseph into Egypt. III. Christ the King sitting at his Table. IV. Of the Love of Christ, and saving Knowledge of it. With A Letter to a Friend, about the Affairs of his Soul. By a Person unhappily taken off from his Ministry by bodily Disorders (Boston, 1748), 62-3. Timothy D. Hall contends that the parochial system proved deeply entrenched in English and New English thought, as it served as the principle means of ordering the land for over a thousand years after the collapse of the Roman Empire. Whitefield's itinerancy thus served as an assault on "a comprehensive network of mental as well as geographic boundaries - a complex set of assumptions concerning the nature of community and its constituent members, the relationship between community and church, the place of the minister in community life, and the plash of the parish and community in the surrounding world." Hall, Contested Boundaries, 18-20.

${ }^{109}$ The Declaration of A Number of the associated Pastors of Boston and Charles-Town relating to the Rev. Mr. James Davenport, and his Conduct (Boston, 1742), 3-4.

110 The Testimony ... at their Annual Convention in Boston, May 25. 1743, 12.
} 
Similarly, Chauncy's Enthusiasm Described sought to instruct Davenport and his followers in "guarding them against the wilds of a heated imagination," as "many good people are offended;

and those, who have no serious concern about religion, are in danger of throwing it off as a wild, disorderly, imaginary business." Chauncy warned again toward the end of his sermon that "Enthusiasm, in all the wildness, and fury, and extravagance of it, has been among [those in other parts of the world], and sometimes had a most dreadfully extensive spread." ${ }^{\prime 11}$ This was a dangerously corrupting disorder, or "a bad temperament of the blood and spirits; "tis properly a disease, a sort of madness" shown on the face of the revival enthusiast: "a certain wildness is discernable in their general look and air; especially when their imaginations are mov'd and fired." With the loosened tongues and bodily convulsions that accompanied these emotional displays, Chauncy observed "such a tincture of that which is freakish or furious, as none can have an idea of, but those who have seen the behaviour of a person in a phrenzy." ${ }^{112}$ The descriptions of frenzied, emotive behavior which led participants to wild and furious actions mirrored similar descriptions of indigenous behavior and religious practice as tumultuous and given to emotions frequently linked with the demonic.

Other ministers worried that revivalists played on the weak-willed and ignorant, exciting their passions over proper intellect, and condemned Whitefield for "an uncharitable, censorious and slanderous" demeanor "which indeed is but a natural consequence of the heat of Enthusiasm... for this Distemper of the Mind always puts a Man into a vain Conceit of his own Worth and Excellency." ${ }^{113}$ Philadelphia minister John Hancock similarly charged Gilbert

\footnotetext{
${ }^{111}$ Chauncy, Enthusiasm described and caution'd against, i-ii, 27.

${ }^{112}$ Ibid., 3-4.

${ }^{113}$ The Testimony of The North Association in the County of Hartford, in the Colony of Connecticut, convened at Windsor, Feb. 5. 1744,5. Against the Rev. Mr. George Whitefield and his Conduct. And An Address From some of the Ministers in the County of Hampshire, to the Rev. Mr. George Whitefield (Boston, 1745), 3. Testimony of the President... of Harvard College, 8.
} 
Tennent as "the grand Instrument of promoting those animal Convulsions into which many of our new Converts have fallen," and argued that his translations of Moravian texts "should be used as a Key to open the cunning, crafty Intreagues and Evasions of the Moravians in propagating their wild and frightful Errors." ${ }^{114}$ Colonists similarly described Indians as weakwilled and prone to religious and theological corruption, particularly within the arena of French influence under Jesuit ministers who promoted Catholicism. From the first instances of contact through King Philip's War, Indian behavior frequently took the form of reactionary, unthinking behavior in colonial accounts. In the context of revivalism, conservative ministers feared that these sorts of behaviors were unbecoming of proper Englishmen and represented yet another form of degeneracy into something akin to unconverted Indians.

Ministers who promoted Indian revival during this period did so with a conscientious regard for the nature of the antirevivalist polemic and the associative link between revivalist enthusiasm and excess with unconverted Indians and the behavior of "natural man." It is also unsurprising that ministers involved in missionary work proved more flexible in their theological predilections and promoted "middle ground" views while tempering their descriptions of Indian revivalism to conform to orthodox understandings of proper sentiment and the dangers of emotional pietism. After unleashing a firestorm of controversy for publishing The Danger of an Unconverted Ministry, Davenport eventually retracted a number of his more radical statements, citing an exchange of letters between Solomon Williams and Eleazar Wheelock as the impetus for his change in thought. ${ }^{115}$ Wheelock's later involvement with his Indian Charity School and role in founding Dartmouth College needs no great description, though this exchange

\footnotetext{
${ }^{114}$ John Hancock, The Examiner, Or Gilbert against Tennent (Philadelphia, 1743), 6, 11.

${ }^{115}$ Gilbert Tennent similarly shifted from 1749 onward to a more moderate position which sought to heal the scars of factionalism by frequently invoking the example of relations between first-century Jewish and Gentile Christians. Milton J. Coalter, Jr., Gilbert Tennent, Son of Thunder: A Case Study of Continental Pietism's Impact on the First Great Awakening in the Middle Colonies (New York: Greenwood Press, 1986), 167.
} 
demonstrates his tendency towards tempering revivalist excess despite his initial support of Whitefield and the premise of religious revival. ${ }^{116}$ The only published sermon of John Sergeant, The Causes and Danger of Delusions in the Affairs of Religion, Consider'd and caution'd against (1743), begins with the premise that ministers should seek a middle ground between extreme positions because as people drifted from the center they became more impassioned and biased in their understanding of the opposing view. Sergeant claimed that his position as a missionary who was detached from the polemics by distance and the nature of his work lent him the credence of impartiality on the issue of revivalism. Adopting a publicly skeptical stance, he wrote:

There may be some Meltings of Heart for Sin, and Tears shed on the Account of it; (which, as I have observ'd, is perhaps the most evident Token of true Repentance), and yet all this Appearance rise nothing above the meer Principles of Nature; at least such Remorse may be so slighty as to make no lasting Impression, nor be effectual in the Life. ${ }^{117}$

Sergeant argued that people might naturally mistake their fear of hell for genuine conviction, "as some notoriously wicked Persons also may be thrown into all the Amazement of distressing Fear without any true Conviction of their Sin," but that ministers should accommodate those who proved overly emotional and zealous because this was a natural byproduct of their dearth of scriptural knowledge and youth in the faith, which tempered with time and education. ${ }^{118}$

\footnotetext{
${ }^{116}$ Two Letters From the Reverend Mr. Williams \& Wheelock of Lebanon, To The Rev. Mr. Davenport, Which were The principal Means of his late Conviction and Retraction. With A Letter from Mr. Davenport, desiring their Publication, for the Good of others. And His Explanation of some Passages in his late Confession (Boston, 1744), 2, 5-8, 20-24. Douglas L. Winiarski has also reexamined Jonathan Edwards' role in the revivals to suggest that initially favored the radical side but tempered his participation and stance when itinerants in the Connecticut Valley invaded his own parish. Douglas L. Winiarski, "Jonathan Edwards, Enthusiast? Radical Revivalism and the Great Awakening in the Connecticut Valley," Church History 74 (2005): 688-90, 696-97, 728-29.

${ }^{117}$ John Sergeant, The Causes and Danger of Delusions in the Affairs of Religion, Consider'd and caution'd against, With particular Refrence to the Temper of the present Times. In a Sermon Preach'd at Springfield, April 4. 1743. In the Audience of the associated Pastors of the County of Hampshire (Boston, 1743), 31.

${ }^{118}$ Ibid., 25-29.
} 
Other ministers involved in missionary activities demonstrated similar attitudes towards facilitating common ground while adhering to a more flexible conception of orthodoxy. Experience Mayhew's 1744 treatise entitled Grace Defended, In A Modest Plea for an Important Truth sought to soften the rancor between Calvinist and Arminian theologies in the wake of brewing revivalist debates. Mayhew introduced his topic by stating that he always adhered to the Calvinist perspective, but believed it necessary "to remove some Things out of the Way, commonly asserted by Calvinists, which I think may be dismissed from their Hypothesis, being no Ways necessary in order to the Support" of their theological system. ${ }^{119}$ Mayhew's examination of good or moral actions serves as a representative example of his critique of Calvinism and a point where his missionary work possibly informed his thinking. He states that “unregenerate Persons may perform Actions that are materially good, tho' they have no Love to God at all; yea, tho' they have no Regard to him." He recognized that anybody held the capacity to do good deeds, though he still placed those actions as inferior to actions taken by the regenerate, for they did so "out of such a Love to God, as has his infinite Perfections for the formal Reason and Ground of it." 120 Oliver Peabody's 1742 sermon on the hope of salvation similarly tempered the zeal of revivalism's claim to absolute certainty of conversion while promoting the gradual progression of faith that Stoddard pushed into mainstream puritan thought decades earlier. $^{121}$

\footnotetext{
${ }^{119}$ Experience Mayhew, Grace Defended, In A Modest Plea for an Important Truth; Namely, That the Offer of Salvation made to Sinners in the Gospel, comprises in it an Offer of the Grace given in Regeneration. And Shewing the Consistency of this Truth with the Free and Sovereign Grace of God, in the whole Work of Man's Salvation. In Which the Doctrine of Original Sin and Human Impotence, the Object and Extend of Redemption, the Nature of Regeneration, the Difference between Common and Special Grace, the Nature of justifying Faith, and other Important Points, are considered and cleared (Boston, 1744), i-iii.

${ }^{120}$ Ibid., 66.

${ }^{121}$ Oliver Peabody, The Foundations, Effects, and distinguishing Properties of a good and bad Hope of Salvation; with Motives to excite all to labour and pray that they may obtain a well-grounded Hope, and some Directions how to obtain it. Considered in a Sermon, The Substance of which was delivered at the Evening-Lecture at the New-
} 
David Brainerd recognized the abrupt effects of transformative grace, as he wrote that "the pagans [Indians] that were awakened seemed at once to put off their savage roughness and pagan manners, and became sociable, orderly, and humane in their carriage." Though this seems incredibly abrupt in nature and a hyperbolic gloss, he tempered this assessment in an earlier passage when he observed:

The strict attention, the tenderness and affection, the many tears and heartaffecting sobs, appearing in numbers in the assembly, would have been very remarkable, were it not that God has made these things common with us, and even with strangers soon after their coming among us, from time to time. I am far from thinking that every appearance, and particular instance of affection, that has been among us, has been truly genuine, and purely from a divine influence. I am sensible of the contrary; and doubt not but that there has been some corrupt mixture, some chaff as well as wheat, especially since religious concern became so common and prevalent here. ${ }^{122}$

In this assessment Brainerd displays optimism in the power of religious transformation as well as a general skepticism towards the immediacy of sanctification that betrays a reliance on the progressive gradualism of Stoddard's sacramental legacy, which led him to conclude that many of the Indian participants were still unregenerate and not fully converted. In passages such as these along with his "general remarks" described in the previous section, Brainerd displays an awareness of the polemics surrounding revivalism and the implications for Indian participants, which shaped his reporting of Indian revivalism and engagement with Christianity during this period. In adapting to this criticism, he and other ministers engaged with Indian work tacitly affirmed antirevivalist critiques. Read in conjunction with the strongest critiques against revivalism and the significance of itinerancy's mobility, anti-intellectual "enthusiasm," and fears of degeneration, antirevivalists betrayed anxiety towards colonial degeneration into a state not unlike their Indian neighbors if revivalists like George Whitefield, Gilbert Tennent, and James

North Church in Boston, on Tuesday June ${ }^{\text {th }}$ 1742. Where a Copy of it was desired for the Press (Boston, 1742), 5, 9.

${ }^{122}$ Brainerd, Life and Diary, 344, 346. 
Davenport prevailed among the populace. In framing their criticisms along this line,

antirevivalists sharpened the distinctions between Englishmen and Indians even further and wove another thread into the complicated tapestry of racial distinction to buttress their own cultural position. $^{123}$

\section{The Limits of Revival}

In a letter dated June 17,1745 , Thomas Coram wrote to the commissioners of the SPG in England to criticize the present state of Indian evangelism within New England, where he had opportunities to observe Indians living nearby in traditional wigwams while he worked as a shipbuilder. Coram criticized the "favourite Ministers" who "had great allowances for doing nothing to any good intent or purpose" with the Indians, except for a yearly "frowlike" in the summer to preach to the small numbers of Indians who gathered near English settlements. Using a well-established rhetorical contrast, Coram described the Indians as "good natured more gratefull \& much honester than the major part of the English inhabiting there," and stressed in a postscript that it would be a "National Advantage" to place ministers in the outskirts of settlements where they could emulate and turn back the influence of French Jesuits who lived in yearlong residence. ${ }^{124}$ While Coram's criticism of mismanaged funds, favoritism, and contrast of noble Indians with perfidious Englishmen represent longstanding arguments by this point in the history of colonial missionary work, the focus on French activity in the context of imperial expansion represents a new dimension that crystallized in eighteenth-century British America.

\footnotetext{
${ }^{123}$ Kathleen Bragdon emphasizes the fact that Indians themselves began to recognize and adapt to this discourse during the eighteenth century to form their own ethnic identity, particularly from the linguistic evidence in which terms for Indians like "nissinuog" or "auwaog people" were supplanted by the more generic and racialized "Indiansog." Oral histories, songs, and legends that survived also reinforced difference through divergent creation accounts and other key cultural markers. Bragdon, Native People of Southern New England, 1650-1775, 223.

${ }^{124}$ Letter, "Thomas Coram to the SPG commissioners in New England, June 17, 1745," Ms. 188, Edward Ayer Collection, Newberry Library. Coram further advocated that the English send full-time ministers to live with the Indians, and to review all potential ministers to find the most paternal and loving workers for this task.
} 
As colonists and British leaders focused increasingly on the issues of geopolitical empires, the scope and purpose of Indian evangelism continued to change and evolve in a colonial context. While missionary work continued in the "old" Praying Towns of Natick, Martha's Vineyard, and Mashpee, attention turned increasingly to the independent and semiindependent Indians living beyond the extent of British hegemony: a process begun in earnest during the revivalist period. ${ }^{125}$ Concern for souls and shoring up frontier defenses thus went hand in hand for Englishmen who recognized the potential for Indian inclusion within colonial society. Emphasizing schooling in English and cultural conversion to British norms, ministers and missionaries affirmed the slow, gradual nature of change within Indian populations, if it happened at all. Pessimism towards Indian conversion tempered the most optimistic revivalist expectations, as the excessive aspects of revivalist religiosity cut against the decorum and lived religion deemed acceptable by the orthodox camp. That many of the antirevivalist criticisms similarly applied to unchurched Indians points to the association between the two, which is reflective of the larger divergence between Indian and English cultures within the colony and the growth of a form of racism grounded in puritan theology. While puritan ministers like Experience Mayhew seized on the theological implications of Stoddard's thoughts as a positive development which facilitated the inclusion of Indians within the colony's ecclesiastical body, missionary work during the revivalist period demonstrates the limits imposed on Indian participation, which missionaries like Brainerd acknowledged and faced in their writings.

It comes as no surprise that Indian participation within an ecclesiastical body wracked by contention over the issue of itinerant ministry and revivalism proved sporadic and problematic.

\footnotetext{
${ }^{125}$ E. Jennifer Monaghan contends that the SPG was "Theologically far less demanding than the Congregationalists and far more confident that salvation could be won by faith, decent behavior, and steady church attendance." The centrality of the liturgy within the Church of England linked missionary work with literacy, and the dual emphases on hierarchy and deference created a strong impetus to "civilize" their subjects. Monaghan, Learning to Read and Write, 143-45.
} 
Over the course of his ministry, David Brainerd managed to accumulate a body of about 130 regular Indian observers who he believed displayed various levels of progress on the path to conversion and sanctification. After baptizing a number of them and admitting a select group to the Lord's Supper, William Tennent asked Brainerd to assist him in a communion service where Indian and English communicants intermingled and supped together on June 8, 1746. Brainerd noted the emotional impact of Indian communicants on his English brethren, as these "aliens from the commonwealth of Israel, and strangers to the covenant of promise" were "brought near to God as his professing people, and sealing covenant with him, by a solemn and devout attendance upon this sacred ordinance." ${ }^{126}$ Access to the sacraments and other English rituals likely appealed to Indians who sought to confront the ever-changing colonial world, as the spiritual efficacy and power the English displayed signaled the favor of a powerful God. The revivalist message of the cosmic imbalance created by sin and the futility of establishing equilibrium by human means also created an imperative to seek God's favor, as did the promise of a better afterlife. Equally important was the newfound interest in mixed associations between Indians and Englishmen in a religious arena, displayed in the writings of Brainerd and the vision Oliver Peabody had for a mixed Natick church. The relatively short missionary careers of David Brainerd (d. 1747), John Sergeant (d. 1749), and Josiah Cotton (d. 1756) in comparison to the tenures of Eliot and Experience Mayhew also undermined their effectiveness as cultural brokers and allies, forcing Indians interested in forming new communities that incorporated English religion to seek new allies in the following years or persist in isolation. As the enthusiasm of revivalism began to wane and the colonies returned to some semblance of religious normalcy, Indian participation with white congregations suffered a parallel decline, though Indians

${ }^{126}$ Brainerd, Life and Diary, 363. 
continued to engage with Christianity and appropriate religious ideas to suit their own particular contexts and needs against the backdrop of imperial expansion and colonial unrest. 


\section{Chapter Six \\ "Those Poor Benighted Pagans": Religious Cultural Divergence and the End of Colonial Missions, 1750-1776}

Moor's Indian Charity School served as an experiment in prevailing notions of missionary work among the Indians, as Eleazar Wheelock sought to train Indians of various tribes to serve as missionaries alongside white pupils. As such, it served as a microcosm of New England with its diverse student body, among them Montauk, Mohegan, Narragansett, Delaware, and Mohawk students. It also displayed the problems of the widening cultural gap between Indians and Englishmen. In a September 25, 1765 letter sent by David Macclure to Eleazar Wheelock in his absence, Macclure relayed a vivid account of a schoolyard fight. A group of boys, including Joseph Johnson, Eleazar's son John Wheelock, and "great William," possibly a Mohawk son of Sir William Johnson, were chatting together by the wood pile and calling each other names. This escalated when John called William a "speckle face white Eye" and dared Joseph to fight William. The two boys took off their coats and continued exchanging slurs like "Son of a Bitch" and "Indian Devil" while the rest of the school gathered around them in a circle and the two began to exchange blows. Macclure interceded and broke up the fight, but the two boys continued to bristle at each other throughout the day, calling each other names. When they later returned to the house "they were not cool'd they went at it again with more fury, tore each other's shirts of their backs." ${ }^{1}$ This brawl between Mohegan and Mohawk boys, instigated by Englishman John Wheelock and taking place within a school designed to "civilize" Indians and raise them to proper English behavior and religion, highlights a number of issues which plagued missionary work in the eighteenth century, namely the conflation of theological constructs with race and racial thought.

\footnotetext{
${ }^{1}$ James Dow McCallum, ed., The Letters of Eleazar Wheelock's Indians (Hanover: Dartmouth College Publications, 1932), 76-77.
} 
The evangelical revivals of previous decades continued to fracture the orthodox landscape of religious life in colonial New England, serving as the impetus for ministers like Eleazar Wheelock and Samuel Kirkland to launch new missionary projects. As Anglo and Indian cultures continued to diverge during this period it created a paradoxical effect on this missionary impulse that forced English ministers to simultaneously affirm God's capacity to save heathen souls while narrowly circumscribing the parameters by which they recognized Indian Christians as their ecclesiastical and spiritual kin when compared to earlier evangelism. The language used within published accounts of Moor's Indian Charity school, sermonic and theological literature, and correspondence between Englishmen and with Indians demonstrates the maturation of rhetoric that decried the spiritual lineage and potential of Indians as "poor benighted pagans." As the anecdote above indicates, name-calling and slurs sparked acrimony between Wheelock's Indian and English students by tapping into wider cultural understandings of Indians and provides a glimpse of the forces at work within Wheelock's school. The boys probably heard the pejorative "Indian Devil" frequently in the company of colonial Englishmen, and possibly from their schoolmaster himself: a term fraught with historical, cultural, and theological connotations. This serves to highlight the problems which contributed to the failure of this venture, and in a wider sense, of colonial missions before war with Britain formally severed political ties between the colonies and the metropole.

An analysis of Wheelock's Indian Charity School serves to underscore the maturation of a theology of exclusion which colonists - even those predisposed to promote evangelical missions as an outpouring of revivalism - held and utilized against Indians when it suited their purposes. The complaints by Indians who attended the school and the correspondence that survives between them and Eleazar Wheelock highlights indigenous perspectives on attending a 
school which held no qualms against the notion that English mores must replace an expunged Indian culture. The shift in focus for missionary activity in general to bolster British geopolitics against France changed the nature and outlook of missionary projects at the same time. From both a fundraising and theological perspective, Britons were content to utilize missions as a means of pacifying potential enemies on the frontier, creating bonds of alliance, and attempting to remake Indians in their own image. At the same time, many Britons held implicit assumptions that spiritual equality and lasting conversions proved the exception rather than the rule, leading them to approach missions with lowered expectations.

Despite the burgeoning trends and cultural currents in effect, Indians challenged these notions when given the opportunity. Others, like Hezekiah Calvin and Jacob Wooley, disaffiliated themselves with Wheelock's projects and rejected attempts to convince them to return to the school. Challenges to these emergent cultural ideas about Indians and their potential to "backslide" as converts proved equally problematic, as Wheelock and other Englishmen frequently wrote them off as affirmation of their preconceived notions about the inbred heathenism of Indians. Faced with the temporal pressures of an economic system slanted towards Indian debt, a profligate alcohol trade, acquisitive land speculators, and a political system that demeaned Indians, it is no surprise that many New England Indians developed an interest in relocating to territory controlled by the Iroquois Confederacy in Oneida territory. The cultural pressures at work against Native Americans like Samson Occom, who represented the pinnacle of efforts to meet stringent white demands, contributed similarly to the impetus to remove and distance themselves from their English neighbors.

Though these plans did not come to fruition until after the American Revolution, the investment of Samson Occom, Joseph Johnson, and David Fowler in this project and their 
rejection of further collaboration with Wheelock and English missionaries represent the cultural failings of the colonial missionary projects. This also represents a failure of theological culture: while colonists preached a message of spiritual equality within the revivalist vein and the notion of spiritual brotherhood shared by converts, the parallel notion of "hereditary heathenism" laden within theological assumptions about Indians and their spiritual capacity doomed the endeavor. ${ }^{2}$ These competing ideas were never resolved during the colonial period or through the missionary projects of the nineteenth century. Beyond temporal slights, Indians recognized that Englishmen failed to truly practice what they preached, resigning themselves to follow a separate path toward isolation. With revolution simmering on the horizon, this represents yet another paradox created by colonialism in which Indians challenged the spiritual hegemony of English ministers and revolted through disaffiliation and confronted the limits of religious community in the eighteenth century.

\section{The Maturation of a Theology of Race}

The development of racialized thinking within New England occurred in a distinct religious context when compared to the Chesapeake and areas of the British colonies with greater populations of enslaved Africans. Though New England lacked the numbers of slaves to properly categorize the region as a slave society, theological constructs and aspects of puritans' Calvinist heritage served to solidify differences between Englishmen, Indians, and the smaller enslaved

\footnotetext{
${ }^{2}$ Rebecca Anne Goetz has coined the term "hereditary heathenism" in the context of creolized Virginia and the struggle to order enslaved Africans and Indians through conflated "religious and racial categories." This work similarly highlights the irony of growing religious toleration within New England and the parallel constriction of options for Indians to participate in shared religious community. Despite our similar aims, the prevailing weight of theology in the context of New England makes analysis of this central to an understanding of similar developments north of the Chesapeake rather than the centrality of slavery and the legal measures used to encode difference into the law. Rebecca Anne Goetz, The Baptism of Early Virginia: How Christianity Created Race (Baltimore: Johns Hopkins University Press, 2012), 2-11.
} 
population of Africans. ${ }^{3}$ Puritan ministers drew on the doctrine of total depravity to characterize

Indians as base and inhuman, while simultaneously affirming the exceptional nature of salvation dispensed mysteriously by God. This set Englishmen and a select group of Indians apart from the rest of their "benighted brethren." By highlighting the particular curse of Indian drunkenness, ministers during this period stressed the hereditary nature of Indian ways as predisposing them towards hostility against Christianity. The maturation of this aspect of colonial theology during this period colored the subsequent efforts of missionaries and schoolmasters like Eleazar Wheelock, limiting the potential of Indians to achieve salvation and parity within their minds. The affirmation of this concept and use of common phrases within the rhetorical formulae of Indian letter-writing during this period underscores the ubiquity of this discourse, while providing the occasional window into Indian resistance to these ideas.

While the evangelical revivals of the 1740s offered new imperatives for conversion and spiritual soul-searching, their decidedly Calvinist theological underpinnings underscored doctrine while providing greater assurance of election through experiential "awakening." ${ }^{4}$ In a

\footnotetext{
${ }^{3}$ Goetz similarly posits a cultural shift as a result of major warfare. In the case of Virginia it was the 1622 war against Powhatan's people, as the earliest pamphlets defending the idea that Indians might not ever convert emerged by 1630 . Goetz highlights the importance of laws restricting baptism in 1667 as another turning point in creation of categories of difference, along with other legal measures pertaining to servants and slaves. The particulars of New England's experience bear further examination. Goetz, The Baptism of Virginia, 59, 86, 112. Richard A. Bailey's work similarly explores the emergent of racial thinking in New England through an examination of legal authority and efforts to grapple with slavery (on a much smaller scale) and Indians in ordering society. The topical nature of Bailey's analysis makes it difficult to carry on a sustained analysis of theological developments, as his second chapter attempts to condense the entirety of colonial thought pertaining to Indian differences from Eliot to Edwards. Richard A. Bailey, Race and Redemption in Puritan New England (Oxford: Oxford University Press, 2011), 7-9, 40, 94. Heather Miyano Kopelson's recent monograph engages with the development of race in New England in the context of a "Puritan Atlantic" which heavily features Bermuda. Her emphasis on gender and "embodied experience" unfolds in part through the act of disciplining and legal control. While devoting more attention to indigenous efforts to challenge Englishmen, which this chapter similarly does, sustained theological analysis of puritan thought across multiple generations is not the primary emphasis of her work. Heather Miyano Kopelson, Faithful Bodies: Performing Religion and Race in the Puritan Atlantic (New York: New York University Press, 2014), 6-12, 173, 224.

${ }^{4}$ Carla Gardina Pestana traces religious fragmentation to the Restoration as a phenomenon of the emergent British empire, which revivalism hastened through even greater fragmentation while connecting participants to a wider transatlantic movement. Carla Gardina Pestana, Protestant Empire: Religion and the Making of the British Atlantic World (Philadelphia: University of Pennsylvania Press, 2009), 100-01, 187, 197. Erik R. Seeman observes that the
} 
sermon on the totality of depravity, Mendon, Massachusetts minister Amariah Frost wrote: "that so great is the wickedness of man upon earth, such the dreadful moral evil, in the heart of man, while unrenew'd, that there is nothing morally good, within them." Even though the unconverted displayed care for their young and other "good qualities in a graceless state," Frost wrote that "the understanding is dreadfully darkned," and "a woful depravity and deprivation of light, overspreads the minds of the unregenerate." In a sermon on conversion, Mather Byles stressed the "vast Chasm" created in the soul by Adam's first sin. In this state unregenerate state, "madness is in their Hearts while they live." ${ }^{6}$ The totality of this spiritual deficiency drove men mad and polluted their understanding of good behavior and proper religious teaching. While ministers intended these sermons to stir the hearts and minds of their parishioners, this theology extended beyond the gathering of white Englishmen in the New England meetinghouse and coincided with the notion that Indians were innately barbaric.

Ministers interpreted this benighted, unregenerate state as applying particularly to Indians, as Samuel Buell preached during Samson Occom's ordination: "the Heathen Nations, who have been for Length of Time, overcast with rayless Gloom, and benighted with Shadows of Death, may be enlighten'd and enliven'd, by that glorious Gospel, which hath brought Life and Immortality to Light." ${ }^{, 7}$ In a treatise advocating increased missionary work among the Indians,

eighteenth century is marked by greater conflict between the laity and clergy, which revivals served to deepen. As this section demonstrates, ministers advocating missions frequently address the "common complaints" they expect people, including the laity, to raise in objection to their suggestions. Erik R. Seeman, Pious Persuasions: Laity and Clergy in Eighteenth-Century New England (Baltimore: Johns Hopkins University Press, 1999), 3-14, 204-06. Thomas S. Kidd also notes that Englishmen extended the gospel to Indians and Africans yet did not anticipate or desire radical changes to their temporal statuses. Thomas S. Kidd, The Great Awakening: The Roots of Evangelical Christianity in Colonial America (New Haven: Yale University Press, 2007), 213-14.

${ }^{5}$ Amariah Frost, The Substance of Two Sermons, One on the total Depravity of human Nature, while unrenewed; from Gen. 6. 5. The other from Gal. 6. 15. Being a Description of the New Creature. Delivered at Westborough, Dec. 8. 1765 (Boston, 1766), 8, 10, 11-12.

${ }^{6}$ Mather Byles, A Sermon on the Nature and Necessity of Conversion (Boston, 1769), 6-7.

${ }^{7}$ Samuel Buell, The Excellence and Importance of the Saving Knowledge of the Lord Jesus Christ in the GospelPreacher, plainly and seriously represented and enforced: And Christ preached to the Gentiles in Obedience to the Call of God. A Sermon, Preached at East-Hampton, August 29, 1759; At the Ordination of Mr. Samson Occum, A 
Samuel Hopkins wrote that in their present state they "are sunk below the Dignity of human Nature," and in a similar anonymous tract entitled An Essay, Towards Propagating the Gospel, among the Neighbouring Nations of Indians in North-America (1756), the author wrote that they should work "to spread the Gospel, among a poor, benighted, Heathenish People," in order "to remove that horrid Darkness, Superstition, and Idolatry, that has Brutaliz'd and Infatuated French, and Indians! And like to swallow up their Souls in Eternal Perdition." ${ }^{\prime 8}$ In his missionary journal, Samuel Kirkland described the Delaware warrior Squash-Cutter as "rather of a serpentine cast," linking his visage with the demonic visualization and theological implications of the serpent-Satan. ${ }^{9}$ If Englishmen solidified their low view of human - and especially Indian potential through the application of Calvinist doctrine, they simultaneously possessed high expectations for converts. ${ }^{10}$ Mather Byles wrote that conversion was a permanent change in character, and that people often mistook true regeneration: "they fancy that to turn from Heathenism to Christianity is all that is implied in it." ${ }^{11}$ In response to the growing

\footnotetext{
Missionary among the Indians (New York, 1761), xv. Kid observes that Occom's ordination sermon reflects the apocalyptic persuasions of the ministers and the high hopes they had for Occom. This topic of "Christian Indian Exceptionalism" is addressed in greater detail from a theological perspective within this chapter below. Kidd, The Great Awakening, 208-09.

${ }^{8}$ Samuel Hopkins, An Address to the People of New-England. Representing The very great Importance of attaching the Indians to their Interest; not only by treating them justly and kindly; but by using proper Endeavours to settle Christianity among them (Boston, 1753), 10. N.A., An Essay, Towards Propagating the Gospel, among the Neighbouring Nations of Indians, In North-America. Submitted, To the Consideration, and proper Endeavours of Rulers, Teachers, and Christians of all Denominations. By a Friend to Church, and Common-wealth. (New London, 1756), 5, 7. Notes on the Evans Fiche copy of this document attribute it to Solomon Williams based on its publication in New London. As an evangelical minister in communication with Eleazar Wheelock, the impetus for missions fits as well.

${ }^{9}$ Walter Pilkington, ed. The Journals of Samuel Kirkland: $18^{\text {th }}$-century Missionary to the Iroquois, Government Agent, Father of Hamilton College (Clinton: Hamilton College, 1980), 15. Joseph Wooley reported to Wheelock in 1765 that Squash-Cutter died of a smallpox epidemic after his friends and family abandoned him. James Dow McCallum, ed., The Letters of Eleazar Wheelock's Indians (Hanover: Dartmouth College Publications, 1932), 267. ${ }^{10}$ R. Pierce Beaver notes that Cotton Mather stressed in his Magnalia that the standards for Indian Christians were noticeably higher, with the expectation that they conform to the image of "the Puritan man in the New England gathered church." Pierce Beaver, "Methods in American Missions to the Indians in the Seventeenth and Eighteenth Centuries: Calvinist Models for Protestant Foreign Missions." Journal of Presbyterian History 47 (1969): 131. While this mentality certainly existed even with Eliot and Mayhew, it intensified most notably in Mather's day and continued into this period.

${ }^{11}$ Byles, A Sermon on the Nature and Necessity of Conversion, 7, 9.
} 
latitudinarianism of his day, Byles pushed for a more stringent assessment of his fellow colonists' spiritual state that proved even more pressing with the conversion of Indians. ${ }^{12}$

Though some ministers supported missionary work, particularly those sympathetic to the evangelical revivals of the previous decade, a general sense of the futile nature of Indian conversion appears pervasive throughout the New England colonies by this point. At the ordination of Stephen Badger as minister of Natick in 1753, Nathaniel Appleton stressed the "hope for the salvation of all as a sign of God's universal Benevolence," but asserted that this was a desire rather than a general rule in order to avoid the implications of universalism, which conflicted with the Calvinist doctrine of election. While Appleton concluded his sermon on the declining state of the Natick Indians, he expressed a hope in divine grace for them despite their history of backsliding. ${ }^{13}$ In his essay on the imperative for missions, Samuel Hopkins noted that the greatest general objection he faced was "there is no Likelihood of succeeding," highlighting the wider popular opinion that missionary activity wasted time and resources. ${ }^{14}$ In an ordination sermon for missionary Joseph Bowman, Charles Chauncy conceded that missionary activity seemed futile when Indians were "strangely diminished," and "it looks as tho', in time not far

\footnotetext{
${ }^{12}$ Latitudinarianism entered the colony in part due to the popularity of Tillotson's writings. As puritans increasingly emphasized the importance of the "transatlantic partnership" fostered by shared Christianity, they relaxed most notably from 1750-60 toward Arminianism. Bruce Tucker, "The Reinvention of New England, 1691-1770," New England Quarterly 59 (1986): 316. Norman Fiering, "The First American Enlightenment: Tillotson, Leverett, and Philosophical Anglicanism,” New England Quarterly 54 (1981): 310-11, 315. Jacob M. Blosser, "John Tillotson's Latitudinarian Legacy: Orthodoxy, Heterodoxy, and the Pursuit of Happiness." Anglican and Episcopal History 80 (2011): 144, 146-47. E. Brooks Holifield, Theology in America: Christian Thought from the Age of the Puritans to the Civil War (New Haven: Yale University Press, 2003), 127-29.

${ }^{13}$ Nathaniel Appleton, How God wills the Salvation of all Men; and their coming to the Knowledge of the Truth, as the Means thereof. Illustrated in a Sermon From 1 Tim. ii. 4. Preached in Boston, March 27, 1753. at the Ordination of the Rev. Mr. Stephen Badger, as a Missionary with a special Reference to the Indians at Natick. Boston, 1753), 2-3, 25. Hope in the salvation of Indians continued to rest in a millennialist eschatology, as the anonymous essayist in the footnote above similarly stressed that God's mercy predisposed him to desire the salvation of lives, which would lead to a culling of the Gentiles from all corners of the earth in keeping with the millennial interpretation of Romans 11:25. N.A., An Essay, Towards Propagating the Gospel, 4. Samuel Buell's ordination sermon also highlighted that colonists should revel in their day as "we have Reason to believe from Scripture Prophecy, and the present Aspect of Divine Providence, that the Latter-Day Glory is dawning." Buell, The Excellence and Importance, 31.

${ }^{14}$ Hopkins, An Address to the People of New-England, 20.
} 
distant, their race would be extinct." Nevertheless, Chauncy urged Bowman to focus on the spiritual treasures his efforts would produce. Even if he failed to have an appreciative impact on the Mohawk, he would personally benefit in Heaven. ${ }^{15}$ In a letter to Eleazar Wheelock, Robert Clelland, schoolmaster to the Mohegans from 1752-65, wrote with frustration that he "never knew any number of people trample under foot so many mercies, they willfully frustrate all the good intentions of their best \& Sincerest freinds," in favor of liquor and debauchery. ${ }^{16}$ Frustration with the failure of missions to meet English expectations often bled over into frustration toward Indian hosts and schoolchildren. ${ }^{17}$

Beyond a general malaise towards outcomes with missionary work, New England ministers also interpreted the diminishment of Indian strength within the colony as a sign of God's divine will: a curse or active punishment against Indians for their persistent heathenism and prior rejection of missionary overtures that coincided with emergent racialized thought. ${ }^{18}$ In his 1763 narrative of efforts to establish Moor's Indian Charity School, Eleazar Wheelock wrote of "the savage Temper of many" Indians, who rejected missionary overtures: "such are their Prejudices in general, and such the malevolent and ungovernable Temper of some, that none but

\footnotetext{
${ }^{15}$ Charles Chauncy, All Nations of the Earth blessed in Christ, the Seed of Abraham. A Sermon Preached at Boston, At The Ordination of the Rev. Mr. Joseph Bowman, To the Work of the Gospel-Ministry, More especially Among the Mohawk-Indians, on the Western Borders of New-England (Boston, 1762), 26, 41-42.

${ }^{16}$ McCallum, ed., Letters of Eleazar Wheelock's Indians, 38.

${ }^{17}$ This frustration was aided theologically by the development of Edwardean thought which stressed the natural ability of all men to repent: "Insofar as sinners languished in coils of inability, their entrapment had its source in their own wills." Holifield, Theology in America, 143.

${ }^{18}$ David J. Silverman argues that categories of difference existed from the earliest days of colonial contact, and that the Narragansett and other Indians employed these categories to create their own understanding of race as a unifying force. David J. Silverman, Red Brethren: The Brothertown and Stockbridge Indians and the Problem of Race in Early America (Ithaca: Cornell University Press, 2010), 6-7. Silverman highlights this issue especially in light of the Brothertown community's postrevolutionary struggles to maintain its land base and the series of issues they faced regarding white rancor. While this served as a powerful explanatory force for Indian misfortunes, the concept was rooted in white views of Indians and developed much earlier. Ibid., 125-148. Bailey argues that colonists imagined Indians as children of the devil, noting that Eliot even employed this category to describe Indians like Metacom (Phillip) who refused to convert. At the same time, colonists in the seventeenth century believed that this could be changed with conversion. I argue that this became much more difficult in the eighteenth century. Bailey, Race and Redemption, 50, 55.
} 
an Indian would dare venture his Life among them." This pervasive behavior and character needed curing if possible as "they have been inured to [it] from their Mother's Womb," which evidences a new trend in thought linking indigenous practices with hereditary deficiencies. ${ }^{19}$ Similarly, Wheelock wrote in his 1771 account of the school that the Indians held deep-seated prejudices against "their men's cultivating lands, or going into the business of husbandry." In his 1772 supplement, he also argued that if the Indians "will not receive the gospel, they will, as they have done, waste away before it, as the morning dew before the rising sun." ${ }^{20}$ As English attitudes towards Indians hardened, the hereditary effects of sin explained cultural differences in ways unique to Indians. This strain of religious thought also explained or justified the increasing difficulties that Indian communities faced.

After roughly one hundred years of missionary experimentation, ministers in Wheelock's day had adopted Cotton Mather's emphasis on English-only education while adhering to the notion that Indians must convert fully to English social norms. When confronted with difficulty in accomplishing these aims and hesitation from Indians to transform as Englishmen imagined, they conflated Indian struggles with a rejection of the gospel and God's active punishment

\footnotetext{
${ }^{19}$ Eleazar Wheelock, A plain and faithful Narrative of the Original Design, Rise, Progress, and present State of the Indian Charity-School At Lebanon, in Connecticut (Boston, 1763), 20, 22, 25. Within this same tract, Wheelock stressed the need to "subdue their vicious Inclinations" and the expenses incurred "in Endeavours to cure their savage Disposition": language which stresses the hereditary, imbedded character of the Indians he sought to convert. Ibid., 26, 45. Joseph Johnson echoed this language in a letter when he stated "I believe that if the Indians now Refuse the Offered gospel it will be wonder if God dont in his anger cut them of from his Earth." McCallum, ed., Letters of Eleazar Wheelock's Indians, 130.

${ }^{20}$ Eleazar Wheelock, A Continuation of the Narrative of the Indian Charity-School, In Lebanon, In Connecticut; From the Year 1768 to the Incorporation of it with Dartmouth-College, And Removal and Settlement of it in Hanover, In the Province of New-Hampshire, 1771 (Hartford, 1771), 5. Again, within this text Wheelock stresses the evil behavior of Indians "which the general practice of all about htem had made familiar to them from their mother's womb." (21) Eleazar Wheelock, A Continuation of the Narrative of the Indian Charity School, Begun in Lebanon, in Connecticut; Now Incorporated with Dartmouth-College, In Hanover, In the Province of NewHampshire (Portsmouth, 1772), 13.
} 
against them. ${ }^{21}$ At the same time, they also distinguished with greater clarity between the innate nature of Indians and that of Englishmen.

In his 1772 account of the school, Wheelock reported that three boys sent to his school from Canada were the grandchildren of Englishmen captured at Groton and Deerfield around the turn of the century. In keeping with indigenous practices, these captives had become naturalized members of the community and one of the captive's children had risen to a sachem position and proved an able negotiator with the English as he came of age and had children of his own. When these children entered Wheelock's school and he had opportunity to write about their progress in 1775, he went to great lengths to highlight their hereditary differences from common Indians:

Though they were born among the Indians, and have been exposed to partake of their national Vices, as much as Cohabitation, and such early Connections could inspire; yet they appear to be as sprightly, active, enterprising, benevolent towards all, and as sensible of Kindness done them, as English Children commonly are. ${ }^{22}$

Despite their mixed Indian and English heritage, Wheelock chose to emphasize the natural characteristics he saw in these boys by way of their English heritage in opposition to the indolent, unenterprising, malicious characteristics established by the Indian-English cultural binary of his day. ${ }^{23}$ Similarly, in an account relayed to the Massachusetts Historical Society from

\footnotetext{
${ }^{21}$ Bailey notes that spiritual equality did not coincide with temporal equality, which created contention when ministers attempted to incorporate Indians and enslaved Africans within their religious bodies. Bailey, Race and Redemption, 122-28.

${ }^{22}$ Wheelock, Continuation, 1772, 39-40. Eleazar Wheelock, Continuation of the Narrative of the Indian CharitySchool. Begun In Lebanon, In Connecticut; Now Incorporated with Dartmouth-College, In Hanover, in the Province of New-Hampshire. With a Dedication to the Honorable Trust in London. To Which is Added An Account of Missions the last Year, in an Abstract from the Journal of the Rev'd Mr. Frisbie, Missionary (Hartford, 1775), 11. The chief sachem mentioned is probably Joseph Lewis Gill, who missionary Levi Frisbie described as "an Englishman by Blood, tho' an Indian by Education, being descended from two English Captives." (53)

23 This is a conscious construction of Wheelock's in part because of the stark language he uses in his other writings to describe Indians' natural characteristics and the contrarian nature of this construction in relation to the growing emphasis on biblical racism. At the same time, in sermons on depravity like Amariah Frost's, depravity is highlighted as a product of "Mixt Marriages" where the "sons of God" left their own kin and "married the daughters of men." Biblical typology naturally provided a similar impetus to avoid intermarriage with Indians, as God punished "the posterity of godly Seth [when they] intermingled themselves with the excommunicated race of Cain." Note the use of race to describe Cain's lineage. Frost, Substance of Two Sermons, 6. Thus, these boys remained untainted despite their hereditary connection to Indians. Goetz asserts that early understandings of the "curse of
} 
his earlier days as a missionary, Gideon Hawley described the hospitality he received from "a very christian-like Indian" called Jonah (T'hanhanagwanageas) who lived at Schoharry. Hawley attributed his deportment to the fact that his mother was "of French extract, and full blooded, being captured from Canada when very young. Jonah, therefore, was half blood.” In keeping with his Euroamerican bloodline, Hawley noted that he never knew Jonah to engage in the Indians' constitutional sin of alcoholism. ${ }^{24}$

Surviving Indian correspondence during this period also confirms the pervasive nature of this rhetoric regarding Indians, as Indians utilized common phrasing about themselves within the epistolary conventions of the eighteenth century. In a petition to the colonial government of New York, Joseph Johnson stressed his role as a preacher and teacher to the Oneida "in endeavouring to persuade the Indians to a civilized Life, and to embrace the Christian Religion," implying that the Oneida were uncivilized before his mission began. ${ }^{25}$ Similarly, in a letter to Eleazar Wheelock Mary Occom wrote that she was happy to hear that her son Aaron behaved "so well as to give the least Reason to think that there is some hope's of his Reforming." She concluded her brief letter by thanking Wheelock for taking "such a vile Creature as he was into your care." 26 While continuing to seek favors from Wheelock, Mary spoke of her son with debasement to play on the convention of unruly Indian children Wheelock frequently utilized in his own writing: "And who does not know, that Evils so obstinate as those we may reasonably expect to find

Ham" centered on "sin and heresy rather than with any particular physical attributes," which demonstrates the different context of Frost's statement and the importance of his use of the word "race." Goetz, Baptism of Early Virginia, 21, 27.

${ }^{24}$ Gideon Hawley, “A Letter From Rev. Gideon Hawley of Marshpee, Containing an Account of his Services Among the Indians of Massachusetts and New-York, and a Narrative of His Journey To Onghoghgwage. July 31, 1794." In Collections of the Massachusetts Historical Society I:4 (Boston, 1806), 53.

${ }^{25}$ Joseph Johnson, "Petition to the Provincial Congress of the Colony of New York, June 21 1770," Ayer Ms. 453, Newberry Library. David Fowler relied on similar language to describe the gender disorder and heathenish behavior of his missionary charges in a letter to Wheelock dated 24 June 1765. McCallum, Letters of Eleazar Wheelock's Indians, 95-97.

${ }^{26}$ Letter, "Mary (Fowler) Occom to Eleazar Wheelock, 15 January 1767,” Ayer Ms. 655, Newberry Library. 
common in the Children of Savages, will require that which is severe?"27 In a letter to Wheelock, Delaware Hezekiah Calvin wrote of the difficult nature of his work as a missionary, for "Indians will be Indians they will still follow their evill Practices. \&c." Reflecting similarly on his missionary charges, David Fowler, a Montauk, wrote to Wheelock that "they are lazy and inhuman pack of Creatures as I ever saw in the World.” Possibly reflecting the language of Wheelock himself, Mohegan Joseph Johnson signed a 1768 letter to his patron "So I Remain your Ignorant Pupil. and good for nothing Black Indian.” If Johnson threw Wheelock's words back at him within this letter, than the notion that the children in the introductory anecdote heard Wheelock call his pupils "Indian devils" is not farfetched. ${ }^{28}$ Writing to English benefactors and audiences, Indian authors repeated the rhetorical conventions regarding Indians and their nature within colonial theology.

By the middle of the eighteenth century, missionary correspondents and publications increasingly described Indians through the cultural-theological phrase "poor benighted Pagans." They were "poor" in the sense that Englishmen judged them culturally deficient in manner of living and expected exceptional instances of God's transformative power to align them with English practices. They were theologically "benighted": their fallen state created a racial lineage with a proclivity towards malice, spasmodic violence, and drunkenness, which further debased them and set them apart from the lineage claimed by Englishmen. Their benighted state also predisposed them to reject any gospel overtures. The racial link forged by the covenant with God and the doctrine of election served to create a religious dichotomy that privileged Englishmen

\footnotetext{
${ }^{27}$ Wheelock, Plain and Faithful Narrative, 26.

${ }^{28}$ McCallum, ed., Letters of Eleazar Wheelock's Indians, 51, 98, 131. Laura Murray observes that Fowler's characterization of the Oneidas served to rhetorically strengthen the connection between Fowler and Wheelock to make Fowler more like his mentor culturally. At the same time, Murray notes that Wheelock's frequent silences sought to intensify the feeling of dependence on the minister, though in the case of both Calvin and Fowler this unintentionally sparked resistance. Laura Murray, "Pray Sir, Consider a Little: Rituals of Subordination and Strategies of Resistance in the Letters of Hezekiah Calvin and David Fowler to Eleazar Wheelock, 1764-1768," Studies in American Indian Literatures 4 (1992): 50, 58.
} 
and justified the calamities which befell Indians, as well as the probability of failure for missions in general. This culminated in the ultimate binary of Pagan-Christian, etching these differences in theological granite: with the exception of a select group of Indians, most were probably bound for destruction in the face of God's wrath because of their innate depravity. The ubiquity of this phrase underscores its reliance on theological and religious concepts.

Most probably would never convert. At the ordination of Stephen Badger when he assumed his post at the Natick church in 1753, Nathaniel Appleton frankly stated that fault lies with those who perish under God's righteous judgment because "they would not accept of Salvation upon the Terms that it was offered to them" As "the final Destruction of Sinners will lie at their own Doors," Appleton lamented the historical problems facing Natick after Eliot died as evidence of this gospel rejection. ${ }^{29}$ Even the esteemed evangelist George Whitefield labored "under the discouraging apprehension that the Pagans of America, are Canaanites, to be cut off before God's people, and never to be gathered into his Family" according to Wheelock. ${ }^{30}$ Efforts to evangelize Indians crystallized around the concept of the exceptional convert, which held daunting expectations for Indians who sought to enter religious fellowship with their English neighbors. This construct proved tragically brittle, as any deviation from this English vision

\footnotetext{
${ }^{29}$ Appleton, How God wills the Salvation of all Men, 9-10, 14, 17-18, 25. Appleton also infantilized the residents at Natick - people who had been sustained until the ordination of Oliver Peabody by their own Indian ministers - as "Children in Knowledge." (26) Similarly, when laying out the rules for Dartmouth Wheelock noted that the English students should treat their fellow Indian classmates well, "as younger brethren." It is curious whether or not these students truly carried out this directive, as a poem included by Wheelock at the end of this serial publication contained lines like "Beheld the murdering savage mad with spite, Reel to the regions of eternal night," and "On savage mortals who despise their God." Wheelock, Continuation, 1771, 33, 54.

${ }^{30}$ Leon Burr Richardson, ed. An Indian Preacher In England: Being Letters and Diaries Relating to the Mission of the Reverend Samson Occom and the Reverend Nathaniel Whitaker to Collect Funds in England for the Benefit of Eleazar Wheelock's Indian Charity School, From Which Grew Dartmouth College (Hanover: Dartmouth College Publications, 1933), 21-22. In a public address regarding missions to Africa, Ezra Styles referred to Africans as "poor, ignorant, perishing, heathen brethren" of African converts John Quamine and Bristel Yamma. Quoting an excerpt from Phyllis Wheatley within this pamphlet, Wheatley demonstrated that Africans similarly harnessed this rhetoric, stating that "Africa is perishing with a spiritual famine." Ezra Styles, To the Public, There has been a Design Formed . . . to send the Gospel to Guinea (Newport, 1776), 2, 5.
} 
provoked severe backlash against Indian ministers, which demonstrates the prevailing weight of eighteenth-century theological racism in New England.

\section{Indian Christian Exceptionalism and Resistance}

As growing hegemony enabled Englishmen to take an increasingly dim and inflexible stance towards Indian culture, this current of thought forced English ministers engaged in missions to provide even greater proof and assurance that Indian Christians were exceptional and had undergone a marked transformation in keeping with the morphology of conversion. When theological or temporal disagreements occurred, these supporters frequently fell back on the concept of "poor benighted Pagans" to mute Indians' challenges to their authority or objectives and disavowed or attempted to punish their fellow Indian Christians. This propensity to accuse Indian resistors of "backsliding" to uphold their own cultural imperatives demonstrates the fragility of Indian Christian exceptionalism in the minds of many New Englanders and the conceptual counterweight of theological racism. While revivalist supporters like Eleazar Wheelock proved the most zealous about launching missionary projects during this period, they were also equally willing to turn on Indian Christians if they felt justified. At the same time, surviving indigenous writings from this period demonstrate a strong undercurrent of Indian resistance towards the developing theological racism through efforts to reassert a common humanity under God. ${ }^{31}$ As colonial theology continued to shift, it thus proved problematic for Indians who engaged English colonists on religious grounds.

\footnotetext{
${ }^{31}$ Goetz observes similar patterns of resistance within Virginia in efforts to appeal to an older understanding of universal Christian identity. Goetz, Baptism of Early Virginia, 166-67. Kopelson similarly argues that Indian challenges centered on concepts of the corporate body and efforts by Indians during the early missions to preserve aspects of their own culture while adopting Indian dress and hairstyles. Kopelson, Faithful Bodies, 173.
} 
Ministers continued to endorse missions primarily through a millennialist eschatology that stressed the calling of Jews and a select number of Gentiles as a predecessor for Christ's second coming. ${ }^{32}$ They also recognized the transformative nature of conversion which would "spread the Gospel, among a poor, benighted, Heathenish People" to pull them from "the Depths of Ignorance and Barbarity" as part of God's general promise to all nations - even Indians. ${ }^{33}$ In his sermon on conversion, Mather Byles likened the convert to the "little children" of Matthew $18: 3$, stressing that "conversion" etymologically meant "to turn" or "turning about," which he expected to occur within the individual convert. ${ }^{34} \mathrm{~A}$ popular pamphlet on its sixth printing in 1773 entitled The Conversion of a Mehometan, To the Christian Religion, Described in a Letter From Gaifer, in England, To Aly-Ben-Hayton, his Friend in Turkey expresses the high view of conversion promoted within evangelical circles. While the text is assuredly polemical, recounting the journey of an Islamic man named "Gaifer" and his correspondence to "Hayton," the tract represents both the ideal of evangelical conversion and an attack on the established Church of England. Within it Gaifer reflects on the critical role the bible played in providing him answers to his questions, though he attributed salvation to grace alone. Gaifer wrote that salvation created a new reality and effected a spiritual change that was total in nature: "Now I [have] begun to live." ${ }^{35}$ Though colonists held high expectations of Indian converts in Eliot's day as well, the exceptional quality stressed by commentators and supporters during the eighteenth

\footnotetext{
${ }^{32}$ N.A., An Essay, Towards Propagating the Gospel, 3-4. This piece especially cites Romans 11:25 as calling for a Gentile conversion around the world before a Jewish culling.

${ }^{33}$ Ibid., 5. Hopkins, An Address to the People of New-England, 26. Chauncy, All Nations of the Earth blessed in Christ, 2, 22-23.

${ }^{34}$ Byles, Sermon on the Nature and Necessity of Conversion, 5-6. Richard Bailey notes that it is somewhat ironic that this imagery of children and infantilizing tendency ensured that Englishmen treated Indians like children intellectually by catechizing them and lumping them into this same category while still holding them to the social and legal expectations of adults. Bailey, Race and Redemption, 55-58.

35 "Gaifer," The Conversion of a Mehometan, To the Christian Religion, Described in a Letter From Gaifer, in England, To Aly-Ben-Hayton, his Friend in Turkey, $6^{\text {th }}$ edition (New London, 1773), 8-9, 11, 17. Thomas S. Kidd stresses the polemical and formulaic nature of this tract in American Christians and Islam: Evangelical Culture and Muslims from the Colonial Period to the Age of Terrorism (Princeton: Princeton University Press, 2009), 15.
} 
century proved necessary when faced with an imbedded culture of Indian-hating and sharpened theological distinctions against them.

When Indian Christians followed the orders of their missionary superiors - a hierarchy promoted by Wheelock in his first charity school account - English correspondents wrote favorably of them. ${ }^{36}$ They wrote in equally laudatory ways when notable Indians died in good standing. In letters to Wheelock dated 1775, both Gideon Hawley and Levi Frisbie wrote well of Sam Gilbert and Joseph Johnson. Hawley stated that Gilbert did "honor to your College," and Frisbie referred to Johnson as his brother. ${ }^{37}$ In a 1793 letter to Nathan Freeman, Hawley gave a brief account of the Indian families at Mashpee since Richard Bourne's tenure as missionary, referring to the Popmunnuck family as "first in dignity." Linking sobriety with piety, Hawley wrote that a number of the community leaders lived pious lives and refused alcohol, dying as good Christians by his estimation. ${ }^{38}$ When he observed a mortuary ritual among the Iroquois, Samuel Kirkland articulated conflicting feelings about the scene: as they danced and kept music “others halloed \& some screamed \& yelled like dogs.” Bewildered, Kirkland noted that "it produced a variety of feelings in my breast, finally a tender pity \& compassion towards them prevailed considering their ignorance \& superstition." ${ }^{39}$ Over the years Kirkland became more accustomed to indigenous culture and began baptizing children and adults who appeared to satisfy his expectations of moral reform and true belief, writing of one man that he "is hopefully become a true Christian." The ambiguity of this statement suggests both the resignation to pierce

\footnotetext{
${ }^{36}$ Wheelock, Plain and Faithful Narrative, 16, 18.

${ }^{37}$ Letter, "Gideon Hawley to Eleazar Wheelock, 10 August 1775," Ayer Ms. 374, Newberry Library. Letter, "Levi Frisbie to Eleazar Wheelock, 30 December 1774," Ayer Ms. 301, Newberry Library.

${ }^{38}$ Letter, "Gideon Hawley to Dr. Nathan Freeman, 1 March 1793," Ayer Ms. 374, Newberry Library. In this letter, Hawley was most interested in giving an account of important Indian families, so he failed to mention that Bourne's son Shearjashub served as an English administrator until his death. Bourne's grandson Joseph then took over the role of pastor in 1719 but resigned in 1742 and "complained bitterly of the treatment the Indians had received." Mary Farwell Ayer, Richard Bourne, Missionary to the Mashpee Indians (Boston: Press of David Clapp \& Son, 1908), 6.

${ }^{39}$ Pilkington, ed., The Journals of Samuel Kirkland, 11.
} 
the veil of the flesh promoted by Stoddardeism and the ambiguity of indigenous conversion as a common motif in missionary writings during this time. ${ }^{40}$

Samson Occom served as the principal example of the "exceptional Indian" during his early ministry, while simultaneously demonstrating the fragility of this exceptional status when applied to living Indians. In the ordination sermon published after Occom became a minister, Buell stressed in a prefatory letter on the Mohegan's character that Occom experienced "Conviction of the moral Pollution of his Nature" as a hallmark of his conversionary experience. Proof of this total change lay in the fact that since his conversion Occom had not gotten drunk, which represented his spiritual liberation from the "Indians' Constitution Sin." ${ }^{41}$ When Wheelock, Solomon Williams, and Charles Jeffrey Smith corresponded on the topic of sending an Indian minister to England to raise funds for Wheelock's school, concerns regarding Occom's meddling in the Mason Land Case nearly disqualified him from the voyage. Wheelock pushed for Occom to formally apologize before the Connecticut missionary board, where he "made a bold and truly manly and Christian Defence in a Spirit of Meekness," though Wheelock admitted that the men needed to "polish $\mathrm{M}^{\mathrm{r}}$ Occum" to give the best impression. ${ }^{42}$ Maintaining Occom's image remained a crucial concern for both Occom and the ministers who supported his work and fundraising trip. Central to this image was the notion that Occom underwent a dramatic transformation that remained total in nature, separating him from the Indians' sin of alcoholism and reforming his character to that of an English gentleman. Attacks on this image thus represent a concerted effort to mitigate Indian exceptionalism and to demote Occom to the standing which most colonists expected of Indians.

\footnotetext{
${ }^{40}$ Ibid., 61. Writing positively of Indian advances in doctrinal knowledge and heartfelt belief, Kirkland relayed this information to justify in part his opening of the communion table to the Indians to whom he ministered. Ibid., 64.

${ }^{41}$ Buell, The Excellency and Importance, vi, ix.

${ }^{42}$ Richardson, ed., An Indian Preacher in England, 20-21, 24, 28-31, 34.
} 
While waiting in Boston to embark on his journey, Occom experienced colonial rancor firsthand when colonists spread rumors that he could not speak indigenous languages or read English while barring Occom and Nathaniel Whitaker from preaching in their churches. ${ }^{43}$

Colonial racism continued to follow Occom when Sir William Johnson alerted Wheelock and

Occom that the SPG had sent an Indian who could not speak English to pantomime Occom in an effort to sabotage his efforts. While in England, a pamphlet parodying Occom entitled A Cry From the Wilderness: Or, a Converted Indian's Address to a Xn. Congregation (1767) circulated to imply that he was only recently converted. In response to the slights in Boston and London, Occom drafted two autobiographies which sought to "give the World in a few Words, the true Account of [his] Education." Stressing his heathen origins in both documents, he extended the second draft to give a full account of his conversion, work with Wheelock, and service as a missionary over an extended period of time. As other scholars have previously noted, Occom's journey served as a turning point in his own personal and spiritual development as he increasingly recognized the prevailing cultural forces against men like him which he had remained somewhat isolated from as an Indian missionary. ${ }^{44}$ Despite these efforts to tarnish

\footnotetext{
${ }^{43}$ Ibid., 75-78. John Morehead was the only minister who allowed Occom to address a white crowd while in Boston. While waiting, the pair also discovered that Charles Chauncy and the Boston missionary commissioners actively worked against them because of Wheelock's revivalist proclivities. Ibid., 120-24, 131.

${ }^{44}$ Ibid., 48, 304. The pamphlet, which was described one English correspondent as "below Grub Street" and "low, foolish \& malicious." N.A., A Cry From the Wilderness: Or, A Converted Indian's Address to a Xn. Congregation (Norwich, 1767), 2-4. Drafts of Occom's autobiographies are included in Joanna Brooks, ed., The Collected Writings of Samson Occom, Mohegan: Leadership and Literature in Eighteenth-Century Native America (Oxford: Oxford University Press, 2006), 51-58. Eileen Razzari Elrod asserts that Occom's autobiographical drafts undercut the traditional puritan narrative of spiritual transformation by making explicit the circumstances of cross-cultural contact which shaped his life. By complaining at the end of the second draft about mistreatment at the hands of colonists and even missionaries, Occom asserted both his Indian identity and "confronts his contemporaries with their own self-making” by criticizing their behavior. Eileen Razzari Elrod, “'I Did Not Make Myself So . . .': Samson Occom and American Religious Autobiography," in Christian Encounters with the Other, ed. John C. Hawley (Washington Square: New York University Press, 1998), 136, 144-46. See Chapter 3, "Betrayals" in Silverman, Red Brethren, 70-88. Drew Lopenzina suggests that the fundraising trip may have been a calculated effort by whites to remove Occom from the colonies due to his renewed involvement in the Mohegan land case and his popularity within the community. Drew Lopenzina, Red Ink: Native Americans Picking Up the Pen in the Colonial Period (Albany: State University of New York Press, 2012), 223-24.
} 
Occom's exceptional character in the minds of Englishmen, he and Whitaker managed to successfully raise funds for the school. In a letter to Wheelock, Samuel Savage wrote of his concerns for Occom when he returned, for "the poor indian hath been so Cares'd \& Such respect Shown him even by the great and Noble" that Savage worried Occom "Some times hath almost forgot what he was." ${ }^{45}$ Implicit in Savage's writing is the notion that Occom, however exceptional he might appear to be, was an Indian with a specific place within colonial hierarchies. Savage's concerns proved surprisingly prescient in light of Occom's life when he returned to the colonies and continued to confront the theological gap between Indian Christians and Englishmen.

Positive conceptions of Indian Christians proved tenuous and fragile, particularly for those most intimately involved in missionary projects like Eleazar Wheelock. In the surviving writings of Indians who attended his school it is difficult to find somebody who did not have a major falling out with the Connecticut minister, which led him to write bitterly: "My rising hopes respecting individuals have heretofore been so sadly disappointed in many instances, and I have seen and known so much of Indian ingratitude, hypocrisy, and deceit." Falling back on colonial stereotypes regarding Indians, he continued, complaining that his work often resulted in "a return of enmity and malevolence to their best friends, and kindest benefactors, for the most genuine expressions of friendship and kindness made to them. ${ }^{" 46}$ In his account from the year before, Wheelock wrote with "melancholly" on the status of his converts:

I don't hear of more than half who have preserved their characters unstain'd, either by a course of intemperance or uncleanness, or both; and some who on account of their parts, and learning, bid the fairest for usefulness, are sunk down

\footnotetext{
${ }^{45}$ Richardson, ed., An Indian Preacher in England, 333.

${ }^{46}$ Wheelock, Continuation, 1772, 15.
} 
into as low, savage, and brutish a manner of living as they were in before any endeavours were used with them to raise them up. ${ }^{47}$

Though he praised the resistance some of his pupils displayed regarding "the power of those fashionable vices which were rampant among all their tribes" when they eschewed alcohol, Wheelock quickly disavowed his pupils by explaining the rifts that developed between them as resultant from their innate sinful, heathen nature. He also concluded by 1771 that English ministers were the only ones capable of resisting these challenges sufficiently, and should "take the lead intirely, and conduct the whole affair of Christianizing and civilizing the savages." 48

While Wheelock's frustration was personal and intimate, his words also highlight the flexibility of theological thinking and its conflicted relationship with emergent colonial racism, as he easily wrote his students off in this manner. Samuel Kirkland expressed similar lapses as he commented on rumors of a brewing Indian war in a 1773 letter to Wheelock, writing that the young warriors were anxious for battle and that their "former pagan state revived full and fresh in their view." 49 When the spirit of revival appeared to ebb, bringing a halt to the transformations Kirkland attempted to document as resulting from his ministry, he also turned against his Indian brethren. When a sermon on Matthew 22:12 failed to produce his expectant results, Kirkland angrily wrote that "stupidity \& carnal security prevail now to a great degree, except among the professors \& some [of] the wise appear to be sleeping with the foolish." ${ }^{50}$ This seemingly fickle attitude proved vexing for students like Hezekiah Calvin, Samuel Ashpo, David Fowler, and others who attended Wheelock's charity school and wrestled more intimately with English culture and theology.

\footnotetext{
${ }^{47}$ Wheelock, Continuation, 1771, 20. In another letter Wheelock wrote "Temptations I find are too many \& strong $\& y^{\mathrm{e}}$ place, according to $\mathrm{y}^{\mathrm{e}}$ Indian Idiom, too slippery in general, for their own sons when quite alone." Richardson, ed., An Indian Preacher in England, 339.

48 Ibid., 18-20.

${ }^{49}$ Pilkington, ed., The Journals of Samuel Kirkland, 84-85.

${ }^{50}$ Ibid., 95.
} 
Writing to Gideon Hawley about the character of Samuel Ashpo, Eleazar Wheelock opened a June 1761 letter by stating that Ashpo "was Supposd to become a real Christian some Years ago" and had behaved well in his church and school until he got drunk with some sailors from New London. Wheelock also observed that Ashpo had been ordained by a lay exhorter, presumably during the revivals of previous decades, and that his religious beliefs seemed orthodox enough except for the fact that he had "very thoroughly imbibed such independ. ${ }^{t}$ and Brownistic Principles.” In 1767 Ashpo ran afoul of colonial ministers again when he was accused of drinking and "of Quarrell", Indecent, unchristian behaviour," and the Connecticut branch of the SSPCK voted to suspend him as a minister. Unfortunately his response to these charges has not survived. ${ }^{51}$ Hezekiah Calvin's relationship with Wheelock and colonists at large was similarly turbulent, as he incurred the anger of his benefactors in 1768 for drunkenness. In a letter to Wheelock begging forgiveness, Calvin defended his actions by stating that "there was more contributed by Nature, than my own free will" to play on the popular notion of Indian drunkenness. At the same time, he made an explicit theological appeal to their shared humanity by stating "But as all Mankind are subject to failings, \& none perfect, I am consequently liable to step aside in Liquor \& commit Errors." He had apparently mocked Wheelock's nighttime lecture in a drunken state, though he stressed he thought this unlikely, promising to be a better example for the students at Wheelock's school. ${ }^{52}$

The frequency with which the Indian students at Wheelock's school were accused of drinking attests in part to the difficulties of navigating an English culture that proved overtly hostile to them, and the frustration many Indians had with the hypocrisy of the colony's most religious members. Edward Deake sent Wheelock a letter in 1768 giving an account of some of

\footnotetext{
${ }^{51}$ McCallum, Letters of Eleazar Wheelock's Indians, 35, 45-46.

${ }^{52}$ Ibid., 60-62. In another letter, a despondent Calvin stated that "the Devil is always tempting me to some mischief, \& It seems to me that I am as ready to comply as he is to tempt." Ibid., 66.
} 
the vocal criticisms Calvin continued to raise against his former schoolmaster. Calvin apparently complained of the hard labor expected of Indians, accusing Wheelock of working Mary Secutor and Sarah Simon "as if they were [his] Slaves," and denying Indian students the personal effects their parents sent with them. When Mary requested a small piece of cloth with which to make slippers, Wheelock apparently said "twas to good for Indians." Finally, Calvin accused Wheelock of restricting their education because it will "make them Impudent." The inability of Wheelock to treat Indians as befitted their common humanity remained the common point through all of his criticisms. ${ }^{53}$ Joseph Johnson also ran afoul of Wheelock in 1768 when he spent about a week drinking and sleeping with Indian women, to which Johnson stated he felt "in Some Measure the down Cast Spirits of Cain when he received his curse" in an apologetic letter. Samuel Kirkland wrote that Johnson was "actually in $y^{\mathrm{e}}$ Devils service," and that he "is fond of Changes" since he wearied of "puritanic Relig" when he "painted, sung - danc'd - drank \& whor'd it." ${ }^{54}$ Johnson managed to overcome the stigma of his behavior and stressed in a later letter to Wheelock the efficacy of the transformation in "this once Savage Heart of mine." Acknowledging that he deserved hell for the sin and provocation of God, Johnson expressed hope in the transformative power of God's grace and his desire to continue in religious service, though by this point in 1774 he had invested himself in the removal of New England Indians to Oneida territory ${ }^{55}$ While frustration with inequality and the somewhat hypocritical views patrons

\footnotetext{
${ }^{53}$ Ibid., 65. David Fowler similarly linked labor for Wheelock with slavery in a letter written to secure funding from the schoolmaster. Fowler wrote "I have been so faithful to you as if I was your Negro, yea I have almost kill'd myself in Labouring." Ibid., 103.

${ }^{54}$ Ibid., 136-41.

${ }^{55}$ Ibid., 172-77. This incident also confirmed the common notion that efforts to mold Indians into Englishmen could easily become reversed once Indians entered their natural setting in the woodlands and returned to their own people. In the confessions of Calvin and Johnson, both stress their willful action despite assurance of grace, which Tammy Schneider argues reveals the theological leanings of the Indians towards Arminianism. This enabled them to express shame and remorse while remaining defiant in the face of the misdeeds they observed in colonist who similarly professed Christianity. Tammy Schneider, “This Once Savage Heart of Mine': Joseph Johnson, Wheelock's 'Indians,' and the Construction of a Christian/Indian Identity, 1764-1776," in Reinterpreting New England Indians
} 
like Wheelock held led many of his students and Indian ministers to act out or eventually confront him, men like Joseph Johnson and Hezekiah Calvin harnessed English religious concepts at times in efforts to mitigate these forces.

In the rare instances when circumstances granted Indian Christians the opportunity to address the wider colony through publication, they used this epistolary venue in efforts to reassert theological equality and promote a vision of shared ecclesiastical fellowship. When an Indian Christian named Moses Paul became drunk and murdered a colonist in 1771, this provided Joseph Johnson and Samson Occom the chance to address both Paul and the wider colonial body through a published letter and a sermon, respectively. Joseph Johnson rearticulated classical Calvinist theology regarding the fate of man and the insufficiency of human action to spare anyone of his or her fate in his letter, for "we are by nature the children of wrath." Johnson warned Paul that hell was the destination for those who fell short of heaven, yet he used this as a chance to criticize the outlook and expectations of his colonial audience:

This is the earnest prayer and desire of many, who have a prejudice against the Indian nations, and wish no better of your soul, than to endure God's eternal wrath, and even rejoice that one of the devilish Indians, (as many express themselves) are suffered to act such apart; and wish that all were as nigh their end. ${ }^{56}$

Johnson stressed the ubiquity of Adam and Eve's original sin as well, stating that this brought God's wrath on all, and it was only by grace that anyone - Indian or English - found salvation. At the same time, he highlighted the rhetorical demonization and dim theological vision of Indians common by this point throughout the colony.

and the Colonial Experience, ed. Colin G. Calloway \& Neal Salisbury (Boston: Colonial Society of Massachusetts, 2003), 232-35, 246-52.

${ }^{56}$ Joseph Johnson, Letter from J---h J----n, one of the Mohegan Tribe of Indians, to his Countryman, Moses Paul, under Sentence of Death, in New-Haven Goal (New London, 1772), 1-2, 5. 
Samson Occom also used the role of the public sermon delivered before Paul's execution and subsequent publication to advance similar criticisms, hoping that his plain style of exhortation would serve more useful than the lofty rhetoric of other ministers. Occom urged believers in the gathered crowd to pray for Paul's soul, while warning unbelievers (and those hostile to Indian Christians) "to consider the frailty of corrupt nature, and behave yourselfs as becomes rational creatures." ${ }^{57}$ Occom's sermon spoke to and confirmed the cultural proclivities of his English audience at times. For instance, he stated that "Sin has made [Moses Paul] beastly and devilish," and devoted a portion of his sermon to chastising the Indians in the crowd regarding the sin of drunkenness, which frequently extended to women and children within their communities.

He also accosted Paul personally for the egregious nature of his sin since he was educated and an Indian Christian, for he "sinned with both [his] eyes open as it were, under the light, even the glorious light of the gospel. ${ }^{n 5}$ At the same time, he also harnessed theology in an effort to temper the hostility of the white crowd and to promote shared Christian brotherhood. Occom reminded the crowd that the devil frequently fought against moments of change and reform, arguing that he had done so with the recent reformation and those who "rise up against the good work of God, calling it delusion, and work of the devil." Defending revival and reformation, Occom affirmed the spiritual benefit of missionary work among men like Moses Paul. Similarly, he stressed the equal fate of all sinners who suffered a "second death" in Hell: "Negroes, Indians, English, or of what nations soever, all that die in their sins, must go to hell together, for the

\footnotetext{
${ }^{57}$ Samson Occom, A Sermon, Preached at the Execution of Moses Paul, An Indian. Who was executed at NewHaven, on the Second of September, 1772; for the Murder of Mr. Moses Cook, late of Water-bury, on the $7^{\text {th }}$ of December, 1771. Preached at the Desire of said Paul (New Haven, 1772), 3-4.

${ }^{58}$ Ibid., 10, 23, 28-29, 31.
} 
wages of sin is death." By quoting scripture and linking these three groups in a common fate, Occom reminded his crowd and readers that they all shared a common humanity and fate. ${ }^{59}$

While colonial evangelists hewed to ingrained ethnocentric notions of the morphology of conversion and expected dramatic changes in the behavior of Indian converts, the maturation of colonial theology in the eighteenth century created a prevailing tendency to exclude all but the most notably exceptional Indians like Samson Occom. While the practice of remembering the exceptional dead existed early on in the form of Eliot's Indian Dialogues and Experience Mayhew's Indian Converts and continued in the missionary work of Gideon Hawley and Samuel Kirkland, the growing body of Indian literature during this period attests to the challenges that Indians presented when they eschewed English ministerial authority or challenged their spiritual "betters." The tendency of even the most stringent promoters of colonial evangelism like Eleazar Wheelock to embrace the formulae of the poor, benighted pagan confirms the seductive appeal of this theological current, as it mitigated such challenges and reinforced the notion that Indians perpetually struggled with their savage dispositions even in the cases of exceptional transformation. In the occasions where Indian letters survive, and in the more public writings of Joseph Johnson and Samson Occom, Indians attempted to curb this tendency by reiterating their shared humanity and the ubiquity of total depravity across all cultures and nations. While they affirmed characteristics white Christians sought to imbue them with - drunkenness as a "national $\sin$ " being the chief one - they frequently countered and rebutted these trends when presented with the opportunity.

\footnotetext{
${ }^{59}$ Ibid., 9, 17.
} 


\section{Marginal Missions}

Beyond the practical usefulness of couching missionary endeavors as complementary to imperial aims from a fundraising perspective, the maturation of this exclusionary vein of colonial theology served to undermine the purpose and expectations of evangelists. Examples from accounts by Samuel Kirkland and Gideon Hawley reflect the contradictory issues of colonial theology, which simultaneously affirmed the potential for God to bring change to any soul held in bondage by original sin and the narrow view of Indians which suggested that such change came about only rarely and in exceptional cases. As a result, many ministers consigned themselves to the material benefits missionary pacification would bring while abandoning the notion that widespread conversion would occur. At best it appeared a hollow and unlikely outcome.

In the heightened wartime sensitivity that shaped the eighteenth century, the close proximity to French territory and their Indian allies drew the attention of English ministers who recognized the successes of the Catholic missionary program. ${ }^{60}$ In his sermon at Stephen Badger's ordination, Nathaniel Appleton noted that English missionary work throughout the colonies was the principal means to "secure Peace, and maintain a friendly Correspondence" with Indians in the region, hoping that Badger's work at Natick might revitalize these efforts. ${ }^{61}$ In his treatise on missions, Samuel Hopkins similarly observed that attempts to destroy the Indians might suffice, but that missions were more Christlike and loving, and would prove

\footnotetext{
${ }^{60}$ For a detailed examination of this competition between Protestants and Catholics in the more immediate context of Massachusetts Bay's Maine borderlands, see Laura M. Chmielewski, The Spice of Popery: Converging Christianities on an Early American Frontier (Notre Dame: University of Notre Dame Press, 2012), 188-209. ${ }^{61}$ Appleton, How God wills the Salvation of all Men, 27. Andrew Porter observes that the relationship between missions and empire frequently "placed missions at odds with the practical consequences of imperial expansion and rule." He similarly observes that the SPG's launch in 1701 signaled the first overtly imperial missionary endeavor with its most concentrated pre-colonial efforts centered on the years of centralization following the Seven Years' War. Colonial Presbyterian and Congregationalist ministers thus found themselves in frequent competition with their Anglican peers. Andrew Porter, Religion versus empire? British Protestant missionaries and overseas expansion, 1700-1914 (Manchester: Manchester University Press, 2004), 13, 16-17, 21.
} 
beneficial by attaching them to British interests rather than the French. Outlining his

expectations, he stated that missionaries will "remove their Barbarity, correct their Manners, reform their Lives, promote in them virtuous Sentiments, and by Degrees form them to true Religion," presumably in that order. ${ }^{62}$ Charles Chauncy observed that this geopolitical shift was likely a sign that God wanted the English to convert Canadian Indians from their traditional practices and expunge Catholicism for the region as the Seven Years' War drew to a close, overtly linking imperial and religious expansion. ${ }^{63}$ Following the war, Wheelock observed that through God's divine dispensation the Indians served as "a sore Scourge to our Land, and make such Depredations on our Frontiers, inhumanely butchering and captivating our People.” While he advocated building missions rather than forts to pacify the borderlands, Wheelock also stressed that the English were obligated to do this by God at the very least. ${ }^{64}$ Thus, if many ministers held serious doubts regarding the capacity for Indians to fully convert unless they proved exceptional, some promoted missions as the panacea which might cool natives' hereditary passions, dispel popery from the region, and strengthen the empire as a whole.

Both the low expectations regarding conversionary results for "poor, benighted Pagans," and the high expectations placed on exceptional converts problematized missionary work during this period. Remarking on the issues plaguing missions to Iroquoia in 1772, Wheelock bitterly wrote "they are nigh unto cursing" when Iroquoian neutrality distanced them from missionary

\footnotetext{
${ }^{62}$ Hopkins, An Address to the People of New-England, 5, 7-9, 19. The anonymous pamphlet An Essay, Towards Propagating the Gospel (1756) similarly stressed the importance of missions "to Reduce all Canada, to Obedience, to the Crown of Great Britain," advocating that the colonies open up a "Worldly Sanctuary" following the examples of Moses and Solomon's court of the Gentiles to take in Indian children for instruction. N.A., An Essay, 6, 11-13. In an appendix to his 1775 account of Dartmouth, Wheelock and the other missionaries reflected briefly on the French Catholic method of building a town with a missionary installed as a central figure and questioned whether or not the Protestants should consider this as well, though the Revolutionary War cut these plans short. Wheelock,

Continuation, 1775, 50.

${ }^{63}$ Chauncy, All Nations of the Earth blessed in Christ, 46.

${ }^{64}$ Wheelock, Plain and Faithful Narrative, 11-12.
} 
overtures. ${ }^{65}$ When Jacob Fowler moved his family to Dartmouth in order to work at Wheelock's school to support his impoverished family, he also brought Indian boys with him. With characteristically lofty aspirations, Wheelock wrote: "If God shall graciously make these Youths the subjects of his special Grace, and furnish them with all necessary Knowledge... may we not hope that their united Force will be terrible against the Kingdom of Darkness, in the Wilderness. ${ }^{, 66}$ In his correspondence from Stockbridge, schoolmaster Stephen West expressed thanks for the catechisms and prayer books he recently received, though he flippantly stated that he "cant but hope that at least, some of them will be profited by them \& make a good use of them. ${ }^{.67}$ Missionaries and evangelicals active from 1750 through the American Revolution were steeped in a growing culture of Indian-hating that frequently demonized Indians through borderlands conflicts and praised the heroism and cruelty of bounty hunters like John Lovewell and Tom Quick. The impetus to engage in missionary work clashed jarringly with popular notions of Indian characteristics and the current of theological paganism which undergirded such beliefs. ${ }^{68}$ The clash between lofty ideal and dismal reality frequently played out within missionary writings on the margins of empire.

\footnotetext{
${ }^{65}$ Wheelock, Continuation, 1772, 16.

${ }^{66}$ Wheelock, Continuation, 1775, 15.

${ }^{67}$ Stephen West, "Letter, Jan. 28, 1765," Misc Bd 1765 Jan 28, Massachusetts Historical Society.

${ }^{68}$ In a recent monograph on Lovewell's death during Dummer's War at the hands of the Pigwacket Indians, Robert E. Cray highlights both the growing brutality of borderlands warfare from 1673 to 1725 and the politics of memory which shaped Lovewell into an early Euroamerican hero. Robert E. Cray, Lovewell's Fight: War, Death, and Memory in Borderland New England (Amherst: University of Massachusetts Press, 2014),1-17. Wartime violence in the borderlands particularly shaped English perceptions of Indians during the Seven Years' War as well, especially as the practice of taking captives and subjecting them to Indian lifeways came to represent proof of Indian barbarity. Fred Anderson, The War That Made America: A Short History of the French and Indian War (New York: Penguin Books, 2005), 152-62. For an extended treatment of the war, see Fred Anderson, Crucible of War: The Seven Years' War and the Fate of Empire in British North America, 1754-1766 (New York: Vintage Books, 2000). Skillful negotiation in the borderlands prevented conflicts in isolated cases, though the wider scale of wartime violence made it difficult for "cultural brokers" to stem the tide of grievances between Indians and colonists. James H. Merrell, Into the American Woods: Negotiators on the Pennsylvania Frontier (New York: W.W. Norton \& Company, 1999), $157-$ 78. Patrick Griffin observes that the violence spanning the Seven Years' War and the American Revolution solidified hostility against Indians as national policy in the early Republic in Patrick Griffin, American Leviathan: Empire, Nation, and Revolutionary Frontier (New York: Hill and Wang, 2007), 3-16. At the same time, issues of land and political sovereignty were at the heart of Indian efforts to defend themselves and navigate the politics of
} 
When he first entered Iroquoia in 1764 to serve as a missionary among the Seneca, Samuel Kirkland remarked within his journal that "how soon the scene is changed and my bright prospects are beclouded and overspread in an impenetrable gloom" when the male within the host family the Seneca sachem placed him with died mysteriously just four days after his arrival. ${ }^{69}$ Charged with witchcraft, the leader of the accusatory faction named Onoonghwandekha feared that Kirkland harbored "a dark design," and argued that his bible "was never made for Indians." Instead, their gods had written a book upon their hearts and minds which many Indians had neglected. Reflecting on the plight of eastern Indians, Onoonghwandekha saw the subjection of those people, and the grandsons of proud warriors had "all become mere women!"70 Though fearful for his life, Kirkland remarked that Onoonghwandekha's speech was a "foregoing violent rash \& inconsiderate harrangue, whch tended very much to influence the passions," denigrating the accusations as part of the passionate tendencies of heathenish Indians who remained unconverted. ${ }^{71}$ Against all odds the situation became even worse, as a visit to Sir William Johnson shortly after his encounter with Onoonghwandekha at the council meeting during bad storms brought sickness and death to Kirkland's "sister," which gave him reason to fear that the Seneca would blame him for this second death. During the condolence ceremony for the woman's death, Onoonghwandekha continued to accost Kirkland, stating that "if they were about becoming white people, they would soon lose all their martial spirit \& be no better than $d u t c h$ negroes" who adopted English husbandry - "an employment proper only for women." The final

empire between France and Britain. Colin G. Calloway, The Scratch of a Pen: 1763 and the Transformation of North America (Oxford: Oxford University Press, 2006), 47-65. In light of these various forces at play, it is no small wonder that missionaries faced hostility especially in borderlands regions and that this popular conception of Indians coincided with theological maneuverings to edge Indians out of ecclesiastical community after King Philip's War.

${ }^{69}$ Pilkington, ed., The Journals of Samuel Kirkland, 9-10.

${ }^{70}$ Ibid., 24.

${ }^{71}$ Ibid., 25. 
account regarding his Seneca mission described an attempt on his life, which Kirkland attributed to Onoonghwandekha's influence, making this mission an abortive failure overall in his eyes. ${ }^{72}$ In 1767 Kirkland began mission work with the Oneida, which lasted until his ouster in 1775 after the death of Sir William Johnson and the ascent of Johnson's son Guy to his father's post. While delivering sermons and commenting how Indians received his message, Kirkland frequently spoke well of his charges. Rhetorically stating "Oh, when shall the dear Redeemer see of the travail of his soul amongst some of these poor benighted Pagans," he proceeded to document the weeping and presumably sincere religious concern when he delivered sermons on John 14:15, Galatians 3, and Matthew 7:7. ${ }^{73}$ Though Kirkland optimistically gave accounts of lay responses, spiritual transformation, baptism, and redemption, he easily shifted into the language of theological demonization and Indian paganism when challenged or confronted with something he disliked. When he heard rumor of rum entering the community he gathered a group of men to seize the liquor and destroy it in 1767. Kirkland wrote that the drunken Indians accosted him and the unnamed husband of one woman demanded that he pay them half of the cost for the liquor that he destroyed, which he adamantly refused to do. The next day, this man obtained more liquor and attacked Kirkland with a knife as "he attempted to gripe [him] on the Throat." Kirkland managed to disarm and bind the man as he thrashed and struggled. During the commotion the man's wife lashed out at Kirkland as well, demanding that he turn the man loose. As she attacked Kirkland he wrote that "She raged with more Violence, began to strike \& tried to bite like a dog." Portraying this Iroquois couple in passionate, animalistic terms, Kirkland set

\footnotetext{
${ }^{72}$ Ibid., 33-39.

${ }^{73}$ Ibid., 40-42, 58, 60-61, 64-66.
} 
them up as spiritual foils and "Enemies to a work of God" just as easily as he praised Iroquoian affinity for spiritual regeneration and rebirth. ${ }^{74}$

Kirkland also commented on the task of expunging Catholicism, which added greatly to his labors, as "the ignorance of these pagans is such, with some papistical Notions they have conveiv'd." He wrote derisively about the Indian desire to build a church on par with comparable English buildings in 1774, scoffing that their insistence on building a steeple and belfry to match English structures stemmed from the lingering effects of Catholicism and their natural affinity for "things that are Showy." Ironically, in a later entry he stated that he had been "cumbered with secular busi[ness], chiefly the Indian Church." That Kirkland considered the building of a meetinghouse a secular affair attests to the conflicting way in which he viewed Indians on the path to spiritual sanctification. ${ }^{75}$ The Oneida appear to have pushed for recognition of spiritual parity, which clashed with the underlying notion that Indians by this period could not aspire to such a standing. For many missionaries, pacification and moral reform appeared far more reachable goals while they continued to hope for the exceptional cases of spiritual revival in the standard Calvinist formulae: any transformation proved the work of God alone in the enslaved hearts of pagans.

Gideon Hawley gave his remembrance of a bewildering journey through Iroquoia at the beginning of his tenure as a missionary in a letter to the Massachusetts Historical Society in 1794. Describing his trip "through a solitary wilderness," Hawley painted an image of an

\footnotetext{
${ }^{74}$ Ibid., 53-54.

${ }^{75}$ Ibid., 66, 94-95. In 1759 the Indian Christians on Martha's Vineyard petitioned through the Mayhews for assistance in building a new church for "publick worship of god." The Wampanoag stressed that their inability to maintain equal practices and buildings was the direct result of English encroachments. Again, it is worth noting that Indian Christians recognized the importance of maintaining parity with Englishmen. Misc Bd 1759 May 1, Massachusetts Historical Society. In another letter they similarly requested payments for missionary services through Zachariah Mayhew. Misc Bd 1759 Oct 1, Massachusetts Historical Society. To his credit, Kirkland did stress his affinity for Indians in general and expressed hesitancy over the Stanwix land deals because he recognized the threat to Indian land. Stephen Valone, "Samuel Kirkland, Iroquois Missions and the Land, 1764-1774," American Presbyterians 65 (1987): 192-93.
} 
environment steeped in hostility. While he described some aspects of native culture positively, attributing an Iroquoian practice of building mounds of rocks and sticks as they traveled common paths as worship of an "unknown God," he also described the wilderness as inhabited "only by savages." Claiming that birds and wildlife abandoned the woods, for they "frequent only the abodes of man," Hawley frequently found himself lost and confronted a "most terrible storm of thunder and lightening," which he described as a common occurrence within Iroquoia. Even the people he encountered on the Susquehanna proved tainted by their natural state of sin for they looked "as terrible and ugly as they could, having bedaubed their faces with vermillion, lampblack, white lead, \&c.” As the Indians drank excessively during a ritual for the dead, Hawley stressed that one Indian intended to kill him and that he barely dodged a fatal shot to the head. ${ }^{76}$ Faced with such dim prospects on the rim of English settlement, even devoted missionaries like Hawley displayed a doubleminded sense of the cultural chasm they faced.

\section{Disassociation a Product of Prevailing Religious Culture}

The growing disillusionment of Indian Christians during this period and the development of plans for many New England Indians to immigrate to Oneida territory in a mass exodus demonstrate the failure of the missionary ideal and Indians' rejection of the cultural climate created by theological racism. While colonists continued to display hostility towards their Indian neighbors over material concerns and these disagreements frequently erupted into violence between Indians and Englishmen, the revivals of earlier decades provided hope for Indians who sought to bridge the preexisting cultural gap through religious affiliation. This growing separation movement represents not only a failure of actions and temporal disjunctions, but also the recognition of a growing number of Indians that their white religious brethren had failed to

\footnotetext{
${ }^{76}$ Hawley, "Letter from Rev. Gideon Hawley,” Collections, 50-67.
} 
resolve a spiritual message that preached salvation to all with the growing theological racism of the eighteenth century. Exposure to New England Christianity and the appropriation of theological concepts by Indians ensured that they recognized the potential for religion to pave over other differences along with the refusal by many colonists to entertain this notion. In the end, this failure of religious ideas and contradictory theology served as a prevailing impetus for removal and isolation, especially for Indian ministers like Joseph Johnson and Samson Occom who chafed under English hypocrisy.

In one of his fragmentary writings titled "The Most Remarkable and Strange State Situation and Appearance of Indian Tribes in this Great Continent" (1783), Occom began by reiterating the notion that the prevailing explanation for the plight of Indians following the American Revolution derived from a "Great Curse from God," he quickly deviated from the plight of Indians to consider the character and theology of his former English brethren. Arguing that the Indians suffered under the sort of general curse which all nations bore, as "all Adamites are under a Curse," Occom questioned whether or not the English suffered even more due to their troubled relationship with Indians and Africans:

When I Come to Consider and See the Conduct of the Most Learned, Polite, and Rich Nations of the World, I find them to be the Most Tyranacal, Cruel, and inhuman oppressors of their Fellow Creatures in the World, these make all the confusions and distructions among the Nations of the Whole World, they are the Nations, that inslave the poor Negroes in Such Barbarous manner, as out do the Savage Indians in North America, and these are Calld Christian Nations

Occom continued to lament that Englishmen displayed "such hardness of Heart, as to exercise the utmost Cruelty upon their Fellow $\mathrm{Crea}^{\mathrm{s}}$ or they that are thus Tormented." ${ }^{, 77}$ Shortly after his return from England, Occom wrote in 1768 that many Church of England bishops "are very indifferent whether the poor Indians go to Heaven or Hell. I can't help my thoughts; and I am apt

\footnotetext{
${ }^{77}$ Brooks, ed., Writings of Samson Occom, 58-59. Occom most openly challenged Wheelock on the issue of schooling in a 24 July 1771 letter to his former benefactor. Ibid., 98-100.
} 
to think they don't want the Indians to go to Heaven with them." This spirit quickly extended to Englishmen within the colonies since Occom became embittered and broke association with Eleazar Wheelock when the schoolmaster devoted the funds raised by Occom in England to his new college at Dartmouth, which nominalized Indian education in favor of instructing English students. $^{78}$

In 1769 Occom wrote to Wheelock regarding accusations of drunkenness, signing his letter "I never was so discouraged as I am now." Occom recognized the fragility of Indian exceptionalism when his drinking, such a slight occurrence that he claimed not to remember, led whites to "call [him] a drunkard." Fueled with this ammunition regarding the Indians' chief sin, Occom wrote that "they call me a lyar and rogue and what not, and they curse \& damn me to the lowest Hell." This rigid double-standard against Indians left Occom at a loss for words, as "them pretended Christians are seven times worse that the Savage Indians."79 On an ecclesiastical front, Occom wrote to Samuel Buell in 1773 complaining that the minister who had attended to his ordination failed to keep him abreast of presbytery meetings which he hoped to attend, presumably to have input regarding missionary work and a say in ministerial affairs. Within that same letter Occom conveyed knowledge that the crown had ruled against the Mohegan in the Mason Land Case and his despair regarding the fate of his people. ${ }^{80}$ By this point Occom and a number of Indians including Jacob Fowler and Joseph Johnson felt sufficiently betrayed by colonial ministers to develop a plan to settle among the Oneida away from English influence.

\footnotetext{
${ }^{78}$ Ibid., 86. The interim period of Occom's return appears quite turbulent, as he wrote to Robert Clelland with hostility regarding disagreements with David Jewett. Shortly after this he ran afoul of the Connecticut board for drinking. Ibid., 85, 87.

${ }^{79}$ Ibid., 89.

${ }^{80}$ Ibid., 103-04. Alden Vaughan notes that Occom continued to advocate for his people when he was in England, going so far as to disembark when he was scheduled to depart from Gravesend in March 1768 in an effort to gain an audience. Once the case was settled, he threw his efforts into arranging the remove from Mohegan territory to the Brothertown community. Alden T. Vaughan, Transatlantic Encounters: American Indians in Britain, 1500-1776 (Cambridge: Cambridge University Press, 2006), 203-04, 208-09.
} 
Through their missionary connections, these Indian Christians devised a plan to settle with them and sought to obtain the blessing of colonial missionary organizations and Sir William Johnson. ${ }^{81}$

This move represents not only the culmination of a host of temporal issues and hostility from the wider colonial body, but a more poignant failure on the part of English colonists to adequately incorporate Indian Christians as equals within their spiritual polity. While Occom continued to draw on aspects of his Christian identity to position himself as a community leader, and the doctrines of the English religion as a means of promoting moral and spiritual reform to hopefully stem the tides of colonialism's ill, in his surviving sermons authored while at Brothertown he seized on the opportunity for Indians to claim a spiritual high ground and practice a more authentic form of Christianity than his English brethren. Occom expressed this best in a sermon on Luke 10:26-27: "Thou Shalt Love Thy Neighbor As Thyself." This text provided Occom the opportunity to vent his frustration through an explication of the "golden rule," in which he stated: "many pretend to Love their Neighbours, but their Neighbours are either of their own nation or party... we Should have the Same Love to other Nations as we have to our Nation." Railing against those "Monopolizers" who "Buy up evry Necessary of Life in the

\footnotetext{
${ }^{81}$ Ibid., 109-110. Johnson, "Petition to the Provincial Congress," Ayer Ms. 453, Newberry Library. McCallum, ed., Letters of Eleazar Wheelock's Indians, 180. This strategy proved advantageous to the Onieda, who sought to reinforce the boundary with the New York colony and recognized the favorable status many of these Indians held with colonial governments. Karim M. Tiro, The People of the Standing Stone: The Oneida Nation from the Revolution through the Era of Removal (Amherst: University of Massachusetts Press, 2011), 34-38. This decision was in keeping with the wider Iroquoian strategy to control the borderlands of their territory marked especially by the 1768 Treaty of Fort Stanwix. William J. Campbell, Speculators in Empire: Iroquoia and the 1768 Treaty of Fort Stanwix (Norman: University of Oklahoma Press, 2012). In his correspondence, John Brainerd noted in 1767 that a summer mission the next year would likely be fruitless because most of the Indians would be at the treaty. John Brainerd, "Letter, June 23 1767," Ayer Ms. 105, Newberry Library. Seasonal movement frequently thwarted missionary efforts, as Stephen West similarly remarked from Stockbridge in 1762, complaining that the Indians needed "government and authority over them." Misc Bd 1762 Jan 21, Massachusetts Historical Society. After the war, the Brothertown and New Stockbridge Indians had tenuous relationships with other missionaries, especially John Sergeant, Jr, who frequently used the rhetoric of captivity to describe his personal suffering. Hilary E. Wyss, Writing Indians: Literacy, Christianity, and Native Community in Early America (Amherst: University of Massachusetts Press, 2000), 85-91.
} 
Town or State" as "a Covetous People," Occom excised these people from his conception of true Christian fellowship. ${ }^{82}$ Presumably delivered to a New London, Connecticut audience, Occom's sermon chastised the theological racism of his white audience: "The Savage Indians, as they are so calld, are very kind to one another, and they are kind to Strangers; - But I find amongst those who are Calld Christians, Void of Natural affection, according to their Conduct in the World." Occom hinged his indictment and veiled argument about shared humanity on the issue of African slavery, for he argued "if you can prove it from the Bible that Negroes are not the Race of Adam, then you may keep them as Slaves. ${ }^{183}$ Recognizing their shared subaltern position, Occom implicitly challenged colonists to rethink the theological racism which he found so off-putting and contrary to the teachings of Christianity, arguing in vain for a religious bridge across the widening chasm of early modern racism that he did not live to see.

The outbreak of open warfare between the American colonies and Great Britain contained a number of paradoxes regarding tyrannical governance, a streak of antiauthoritarianism that threatened elite control, and a willingness in some circles to radically challenge the conventions of society. ${ }^{84}$ Colonial arguments prove somewhat ironic when situated against the backdrop of Indian Christian experiences, as they similarly experiences the ill effects of missionary organizations which sought to keep them impoverished and ingratiated to their

\footnotetext{
${ }^{82}$ Brooks, ed., Writings of Samson Occom, 201-05.

${ }^{83}$ Ibid., 206. In his petitions for the Brothertown community that follows, Caroline Wigginton describes Occom's aptitude at fusing metaphors within the petitions to craft an image of community perseverance and revitalization. This is in keeping with Occom's recognition of the spiritual failings of New England's white Christians and the hope that this new project would fulfil his spiritual aims as well. Caroline Wiggington, "Extending Root and Branch: Community Regeneration in the Petitions of Samson Occom," Studies in American Indian Literatures 20 (2008): 25.

${ }^{84}$ James B. Bell stresses the religious causes of the Revolution, particularly surrounding the fears of an American bishopric and the politicization of clergy within the colonies over the course of the Revolution. James B. Bell, A War of Religion: Dissenters, Anglicans, and the American Revolution (Houndsmill: Palgrave MacMillan, 2008), cxvi. See especially Chapter 6 on Jonathan Mayhew's criticisms of the SPG and Chapter 15 on how clergymen weathered the war from 1775 to 1783. Alan Taylor's chapter on the war in The Divided Ground provides an excellent narrative regarding the issues at stake for Indians during this conflict and their responses. Alan Taylor, The Divided Ground: Indians, Settlers, and the Northern Borderland of the American Revolution (New York: Vintage Books, 2006), 77-108. For a treatment of southern issues see Jim Piecuch, Three Peoples, One King: Loyalists, Indians, and Slaves in the Revolutionary South, 1775-1782 (Columbia: University of South Carolina Press, 2008).
} 
English superiors, legal systems which were slated against them, and hardened cultural

conceptions of Indians in general. While Indian Christians sought to challenge these notions at times through theological arguments, the prevailing state of colonial religion proved difficult to overcome. Viewed from a religious angle, the American Revolution represents yet another paradox as it intensified the shift towards latitudinarianism and heterodoxy within New England in particular while, as this chapter demonstrates, colonists continued to view Indians primarily through strict Calvinist theology which undergirded emergent notions of race and Indian exclusion. ${ }^{85}$ Indians continued to participate in this conflict as allies, following a pattern established in the Pequot War and King Philip's War and sustained through the series of colonial engagements with France, many chose to position themselves as neutrals or to remove themselves entirely from the English. ${ }^{86}$ Indigenous connections with English religion again proved a point of contention. In the preface to the 1787 Mohawk translation of the Book of

\footnotetext{
${ }^{85}$ The Revolution obviously did not cause this, as the trend towards latitudinarianism can be traced back to the Glorious Revolution when the Dominion enforced toleration by legislative fiat. Similarly, the growing intellectual trends of the Enlightenment also created a "puritan tribalism" that softened the strict Calvinism through the innovations of ministers like Solomon Stoddard. Pestana, Protestant Empire, 159-65, 182-83. Similarly, Pestana notes that religion played a notable role in revolutionary fears of a Catholic influx and Church of England establishment, but the ecumenical movement of the time also contributed to religious fragmentation and diversity while providing potentially open spaces for indigenous converts. Ibid., 218-22, 257-59. Erik Seeman observes that antiauthoritarianism cemented itself in lay practice well before the revolution and that laypeople interpreted the crisis through the prism of popular piety even though the conflict was largely secular. At least in white circles, the democratization of religion in the early Republic healed the gap between clergy and laity. Seeman, Pious Persuasions, 204-09. See also, Chapter 7: "Religion and the American Revolution," in Patricia U. Bonomi, Under the Cope of Heaven: Religion, Society, and Politics in Colonial America, Updated Edition (Oxford: Oxford University Press, 2003), 187-216. Chris Beneke cites the elected nature of Congregationalists practices as a social and political element to New England life which proved amenable to the import of republican philosophy, with a crucial shift in attitudes toward empire occurring from 1746-1751. Chris Beneke, "The Critical Turn: Jonathan Mayhew, the British Empire, and the Idea of Resistance in Mid-Eighteenth-Century Boston," Massachusetts Historical Review 10 (2008): 25-26. Finally, Thomas S. Kidd notes that Christianity has "had a complex influence on the idea of human equality," citing the radicalism of the revivalist movement in the eighteenth century as evidence for social leveling and the early Quaker attacks on slavery. This impulse became even more radical to Kidd when Jefferson enshrined equality under God's creation within the Declaration of Independence, though I am far more skeptical of Jefferson's motives and theological proclivities, given the historical application of this principle. Thomas S. Kidd, God of Liberty: A Religious History of the American Revolution (New York: Basic Books, 2010), 132-37, 140-46.

${ }^{86}$ In a speech delivered by "Little Abraham" on behalf of the Mohawk, he stated that they desired that the "white people" would "settle their owne quarrels between themselves" for they intended to "never meddle in these Matters or be the aggressors - if we are let alone." Ayer Ms. 6, Newberry Library.
} 
Common Prayer, the editors noted that a new text was especially necessary due to the fact that "in the course of the late American war, most of the Indian Prayer Books were destroyed." 87

While the Revolution severed political ties with Britain, ecclesiastical ties remained as Americans and their British cousins continued to engage in various missionary projects through the nineteenth century. ${ }^{88}$ Though the Bill of Rights enshrined freedom of religion as an important liberty within the new Republic, this did not mean that Americans regarded Indian Christians as their spiritual equals: a point which garishly highlights the theological-racist developments of the prewar era since the old puritan shibboleth of "Arminianism" penetrated the region and greatly widened the notion of spiritual polity for most white Americans in the early nineteenth century. ${ }^{89}$ In that sense, the religious cultural divergence of the eighteenth century cemented the image of Indians as "poor, benighted Pagans" within the American consciousness.

\footnotetext{
${ }^{87}$ The Book of Common Prayer, And Administration of the Sacraments, and Other Rites and Ceremonies of the Church, According to the Use of the Church of England: Together with a Collection of Occasional Prayers, and divers Sentences of Holy Scripture, Necessary for Knowledge and Practice. Formerly Collected, and translated into the Mohawk Language under the direction of the Missionaries of the Society for the Propagation of the Gospel in Foreign Parts, to the Mohawk Indians. A New Edition: To Which Is Added The Gospel according to St. Mark, Translated into the Mohawk Language, By Captn. Joseph Brant, An Indian of the Mohawk Nation (London, 1787), i.

${ }^{88}$ Kidd, The Great Awakening, 305-06. Kidd notes that the service of some ministers like Samuel Kirkland as revolutionary army chaplains undercut their positions with natives as they continued to suffer wartime depredations. In his correspondence, John Sergeant, Jr. noted that Kirkland's return to mission work after the war had provoked the ire of the Indians and that they attempted to oust him by appealing to the SSPCK, though they sided with Kirkland and he planned in 1799 to return again. "Letter, John Sergeant to the Rev. Dr. Morse, 27 February 1799," Ayer Ms. 800, Newberry Library. In the postrevolutionary period the new American government set to parceling out land in the "so-called wilderness" under the 1785 land ordinance. Drew Lopenzina argues that the government "assumed its proprietary authority over the as yet uncharted west, with the management and eventual assimilation (or extermination) of indigenous peoples clearly articulated into this vision." In that same vein, he calls attention to the portrayal of the Brothertown Indians who bordered William Cooper's town in the writings of James Fenimore Cooper. Channeling his ideas through Natty Bumppo, Cooper viewed Occom and his kin as "liminal figures, caught between two worlds." Drew Lopenzina, 'The Whole World Shall Blossom as the Rose': Samson Occom, Joseph Johnson, and the Question of Native Settlement on Cooper's Frontier," American Quarterly 58 (2006): 1125, 112829.

${ }^{89}$ Jon Butler, Awash in a Sea of Faith: Christianizing the American People (Cambridge: Harvard University Press, 1990), 258-68. Frank Lambert, The Founding Fathers and the Place of Religion in America (Princeton: Princeton University Press, 2003), 207-219.
} 


\section{Conclusion \\ Facing Outward and Inward: The Dynamics of Colonial Theology and Religious Community}

At a gathering of Revolutionary War veterans in Natick, Massachusetts held in 1824, John Bailey delivered a commemorative oration extolling the virtue of the new nation and its exceptional founding circumstances, which would prevent it from the indolence and decadence facing other European countries. Though still inhabited by Native Americans on the metaphorical and literal margins of society, Euroamericans had appropriated Natick by this point and Bailey's speech reflects this shift by remaining tacit on Indians and the historical roots of Natick as an experimental religious community. ${ }^{1}$ The ordination of James W. Thompson as pastor of the South Congregational Society in Natick provided a more explicit opportunity for Alexander Young to reflect on the history of indigenous missions from the vantage of 1830. Beginning with a fictitious story of Socrates' visit to Natick in his day, Young extolled the virtues of Christianity as "a universal religion," observing that his faith is "indicative of superiour intellectual light and power" when compared to any other religion. Belittling the treatment of all previous nations for their stance toward outsiders, as Jews showed benevolence only to other Jews and Muslims hated "christian dogs," Christianity's appeal to universal humanity flew in the face of the barbaric cruelty demonstrated by past societies. Praising the Natick of his day, Young privileged American culture and religion over all of Western civilization's prior achievements. $^{2}$

\footnotetext{
${ }^{1}$ John Bailey, An oration, in celebration of American independence, pronounced at Natick, July 5, 1824, before the officers of the regiment militia, comprising the towns of Natick, Farmingham, Hopkinton, Holliston, and Sherburn (Dedham, 1824), 8-14, 20-23.

${ }^{2}$ Alexander Young, Christianity Designed and Adapted to Be a Universal Religion. A Discourse Delivered at the Ordination of the Rev. James W. Thompson, As Pastor of the South Congregational Society, In Natick, Feb. 17, 1830 (Boston, 1830), 4-9, 16-17. Young's emphasis on Christian universality is significant in light of the democratization of religion which intensified following the Revolution. Universalism provided a significant set of "opportunities to expand spiritual belief and denominational membership" with the introduction of new ideas to counter the gloomy elements of Calvinism. Janet Moore Lindman, “'Bad Men and Angels from Hell': The
} 
While obviously revisionist in his treatment of world history from a modern standpoint and culturally hegemonic, Young's sermon demonstrates the prevailing attitudes towards Indians and their engagement with Christianity, which were rooted in the eighteenth century. Highlighting the lofty work of the "venerable Evangelist" John Eliot, he called his listeners to imagine "the simple prayer of the untutored Indian offered up to the Great Spirit in the name of Jesus.” Theologically belittling Indian Christians and their religiosity, Young linked Eliot's death with the subsequent decline of Indian religiosity: "The race of the red man has dwindled and at last disappeared. The forests through which they once pursued their sports and hunted their game, have owed before the axe of the settler, and are succeeded by cultivated fields and pleasant farms." ${ }^{3}$ Without the aid of dedicated missionaries who devoted their lives to battling the heathenish proclivities of their savage cousins, the region's Indians succumbed to their natural fate and simply vanished. ${ }^{4}$ Perhaps that was their fate after all.

Other European and American contemporaries wrestled with the complexities of their religious beliefs and how to interpret the complicated history of missions and Indian Christian

\footnotetext{
Discourse of Universalism in Early National Philadelphia." Journal of the Early Republic 31 (2011): 263, 281. While Lindman notes the debate engendered by Universalism in Philadelphia, in New England the growing latitudinarianism of the eighteenth century quickly transformed to universalism for many of the region's clergymen. Ebenezer Gay of Hingham has been characterized as "a godfather of Arminian dissent," and even Charles Chauncy softened to a universalist position, encapsulated in his posthumous work Salvation for All Men. E. Brooks Holifield, Theology in America: Christian Thought from the Age of the Puritans to the Civil War (New Haven: Yale University Press, 2003), 129, 134. Luigi Guissani writes that Chauncy's work contained "the nucleus of some aspects of the Unitarian Universalist conception of religion." Luigi Guissani, American Protestant Theology: A Historical Sketch (Montreal: McGill-Queen's University Press, 2013), 31.

${ }^{3}$ Young, Christianity Designed and Adapted, 28-29.

${ }^{4}$ Laura M. Stevens observes that these "theological preoccupations and triangular emotional trajectories" for missionaries created a desire for the elusive object of the ideal Indian convert, which enabled British missionaries to "envision plantation, settlement, and trade unfolding benevolently across the canvas of the Indians' souls, until they could look through this increasingly translucent image to each other." Laura M. Stevens, The Poor Indians: British Missionaries, Native Americans, and Colonial Sensibility (Philadelphia: University of Pennsylvania Press, 2004), 110. Regarding nineteenth-century history, Thomas L. Doughton offers a brief sketch of Native American persistence in Massachusetts through the decades of the early American republic, which directly contradicts the myths promulgated by Young. The motif of the "vanishing Indian" generated in the colonial period transitioned into the "vanished Indian" of the early nation, though both myths belied the realities of Native American lifeways. See, Thomas L. Doughton, "Unseen Neighbors: Native Americans of Central Massachusetts, A People Who Had 'Vanished',' in After King Philip's War: Presence and Persistence in Indian New England, ed. Colin G. Calloway (Hanover: University Press of New England, 1997), 207-230.
} 
engagement in the colonial past. In a sermon delivered to the Paisley London Missionary

Society, John Snodgrass admitted that one of the most difficult aspects of Christian theology was

the notion that God remained sovereign in his mysterious decision to save some while allowing others to perish. Stressing the importance of human agency in preaching and spreading the core tenants of his religion, Snodgrass devoted the bulk of his sermon to an exegesis of Isaiah 66:1820, arguing that the text "cannot relate to the return of the Jews from the Babylonish captivity, nor to the subsequent rejection of that people for their unbelief, and the first preaching of the gospel to the Gentiles." Snodgrass concluded that it "relates to a period far distant from these," implying that the text would be fulfilled through present missionary activity. ${ }^{5}$ Eschatological interpretations and efforts to wring meaning out of ambiguous divine writ continued to serve as the impetus for missionary work, especially in the Second Great Awakening. In an address to theological students published at Dedham in 1831, missionary Reuben Tinker stressed the parable of the good Samaritan as an example of the benevolence and charity expected of Christian missionaries. ${ }^{6}$ Duty and service to God thus remained powerful motives for missionary service, regardless of the outcomes expected of indigenous peoples.

\footnotetext{
${ }^{5}$ John Snodgrass, Prospects of Providence Respecting the Conversion of the World to Christ: A Sermon, Preached Before the Paisley London Missionary Society, in the High Church of Paisley, On Friday, June 10th, 1796. With an Appendix, Containing An Account of the Progress and Present State of the Missionary Business (Paisley, 1796), 5-7. English Anglicans continued to conduct missions within British Canadian holdings, though they also displayed a number of shared notions regarding the prospects of Indian conversion. In one report, British commentators noted that the Six Nations faced inevitable absorption into white society and "thus they must be quietly and gradually led to the knowledge contained in the Scriptures," stressing that they already imperfectly worshiped the "Great Spirit." Report By a Committee of the Corporation Commonly Called the New England Company, of Their Proceedings, for the Civilization and Conversion of Indians, Blacks, and Pagans, in the British Colonies in America, and the West Indies, since the Last Report in 1832 (London, 1840), 141-42.

${ }^{6}$ Reuben Tinker, Ought I To Become A Missionary? An Address to Theological Students: By Rev. Reuben Tinker, Missionary to the Sandwich Islands (Dedham, 1831), 4. In an article on nineteenth-century missions to the Sioux, Edwin J. McAllister notes the typographical nature of the period's ethnographic missionary writings, along with the "construction of an easily bridgeable distance separating red man and white" necessary for conversionary writings to work, as "a former state of savagery is contrasted with a present elevated moral and social state." This motif of exceptionalism was rooted most notably in the missionary movements which emerged from the First Great Awakening. Edwin J. Mc Allister, “'Our Glory and Joy': Stephen Riggs and the Politics of Nineteenth-Century American Missionary Ethnography Among the Sioux," in Christian Encounters with the Other, ed. John C. Hawley (Washington Square: New York University Press, 1998), 150.
} 
Writing in the nineteenth century, Pequot minister William Apess attempted to redefine conceptions of religious community in the face of solidified racism and animosity toward Indians. The basic details of Apess's life strikingly parallel those of Samson Occom: born into a community plagued by a dwindling land base in 1798, Apess converted to Methodism during a religious revival held on March 15, 1813 within New London where Apess served as an indentured servant to the elite William Williams family. ${ }^{7}$ Serving as a Methodist circuit preacher and minister to various indigenous communities, Apess became a prominent figure within the new generation of Indian Christians. In his only surviving sermon, The Increase of the Kingdom of Christ, Apess drew on millennial themes and biblical typology in an effort to redefine early American ideas of religious community. Drawing on the text of John 3:30: "He must increase, but I must decrease," Appess opened with the wilderness-dwelling prophet to draw a distinct allusion to the notion of vanishing Indians in his own day. Countering this idea, he drew explicit connection to the old notion that Indians descended from a lost tribe of Israel, warning American readers that they had "reason to fear the swift judgements of heaven on them for nameless cruelties, extortions, and exterminations inflicted upon the poor natives of the forest." America's "national sin" lay in the country's utter failure "to amalgamate the red man of the woods into the artificial, cultivated ranks of social life." ${ }^{8}$ This theme of white depredations remained a common current throughout Apess's works.

Extending this notion even further, Apess felt the need to reassert a common humanity for Indians in The Indians: The Ten Lost Tribes (1831). Declaring that "the soul of the Indian is

\footnotetext{
${ }^{7}$ Barry O'Connell, ed., On Our Own Ground: The Complete Writings of William Apess, a Pequot (Amherst: University of Massachusetts Press, 1992), xxvi-xxvii, xxxi.

${ }^{8}$ Ibid., 101, 106-07. Hilary E. Wyss notes that this inversion does away with the "Anglo-American assumption that Christianizing Natives must involve eliminating their culture." Since their culture was already Christian by nature of a Jewish lineage, Apess "claims for Natives a truer or closer understanding of Christianity by using the very language of the dominant culture." Hilary E. Wyss, Writing Indians: Literacy, Christianity, and Native Community in Early America (Amherst: University of Massachusetts Press, 2000), 163.
} 
immortal," Apess argued that all men "however gifted, and eloquent, and learned, and popular," were by nature under the same burden of sin white Americans transferred to Native Americans. Unregenerate man, whatever the color of his skin, remained a "heathen" and an "enemy to God." In both of these works, Apess imagined a better future where Indian and American communities might join together, as the spirit of revivalism gave him hope that spiritual regeneration within Indian communities might provide the cultural currency for acceptance by whites: "the day as being not far distant when ample justice shall be done the red man by his white brother - when he shall be allowed that station in the scale of being and intelligence which unerring wisdom designed him to occupy." ${ }^{10}$ Though Apess expressed hope for the future, he turned his religious vision chiefly to heaven as a righteous kingdom in contrast with worldly kingdoms like America, which were "confederacies of wrong" where "the powerful trespass on the weak; the rich live in luxury and rioting, while the poor are enslaved and doomed to much servile drudgery, without any hope of bettering their condition." Apess and other Indian Christians in the nineteenth century trusted in the spiritual treasures of heaven, where "the axe is laid to the root of the tree of human corruption."11

Concluding his brief essay on the Jewish lineage of Native Americans, Apess promoted a vision of the precolonial past which appeared a "golden age" for Indians, one that clashed jarringly with an early American understanding of the past. Apess criticized Americans for forgetting "the corroding sorrows of the poor Indians - the wrongs and calamities which were heaped upon them." While colonists and early Americans accused Indians of "cruelty and perfidy of the basest nature," he asserted that Indians "were a harmless, inoffensive, obliging

\footnotetext{
${ }^{9}$ O’Connell, ed., On Our Own Ground, 113.

${ }^{10}$ Ibid., 111,114 .

${ }^{11}$ Ibid., 102.
} 
people. They were alike free from the blandishments and vices of civilized life." ${ }^{12}$ Calling attention to the end results of colonialism and entrenched racism of his day, Apess cast an equally revisionist interpretation on the past by portraying the history of his people and other Native American communities as "a series of cruelties and persecutions without parallel." 13 This work complicates Apess's vision of colonial history by demonstrating the colonial experience in New England as a process worked out primarily within the arena of theology and religious ideas. Divergent notions of religious community across time and space held by both Indians and Englishmen shaped the nature of religious exchange across cultures. Exploring the religious dynamics of these interactions from 1600 to 1775 demonstrates that the attitudes and beliefs of early Americans were rooted in both theological discourse and contested historical events.

The puritans' Calvinist theology proved flexibly inflexible in light of the colonial experience when examined from early puritan settlement through the eve of the American Revolution, as puritans adapted theological concepts to widen the bounds of community in order to foster connections with Native Americans at times or to circumscribe boundaries to their exclusion. As they christened the land in which they settled a "New England," the nature of colonial settlement forced puritans like John Winthrop, Roger Williams, and John Eliot to evaluate their Algonquian-speaking neighbors in light of their culturally-specific religious beliefs. The greatest impetus for missionary work came with the millennial fervor sparked by the

\footnotetext{
${ }^{12}$ Ibid., $114-15$.

${ }^{13}$ Ibid., 113. O'Connell writes that Apess's aptitude for polemics shaped his published works, as his Eulogy for King Philip inverted the dominant colonial narrative by placing Metacom above the "Pilgrim fathers." Apess recognized that a new vision for the nineteenth century meant honestly approaching the past from the perspective of Native Americans as equals. Barry O'Connell, “'Once More Let Us Consider': William Apess in the Writing of New England Native American History," in After King Philip's War: Presence and Persistence in Indian New England, ed. Colin G. Calloway (Hanover: University Press of New England, 1997), 165-66. The emphasis on red and white men as fundamentally different emerged in the racism of the nineteenth century. In the spirit of adaptation, many Indian communities including the New Stockbridge and Brothertown Indians embraced this model and began to restrict connections with black Americans in an effort to distance themselves. Christopher Geherin, "New Guinea: Racial Identity and Inclusion in the Stockbridge and Brothertown Indian Communities of New York." New York History 90 (2009), 141-42, 144. Alden T. Vaughan, "From White Man to Redskin: Changing Anglo-American Perceptions of the American Indian," The American Historical Review 87 (1982): 919, 922.
} 
English Civil War, along with the spiritual directive conveyed in the "Great Commission" of Matthew 28:19-20: "Go therefore, and teach all nations, baptizing them in the Name of the Father, and the Son, and the holy Ghost, Teaching them to observe all things, whatsoever I have commanded you: and lo, I am with you always, until the end of the world, Amen." Though early puritans like Eliot wrestled with where to conceptually place Indians - be it within an ignorant gentile or erstwhile Jewish lineage - commitment to a shared humanity ensured that Eliot's theology flexed to accommodate the concept of Praying Indians and Indian Christians.

That men who held a high view of the behavioral and cerebral expectations for converts could adapt to accommodate Indians and bridge their respective cultural gaps to create a religious "middle ground" attests to the power which religion in general held in these exchanges. In the context of the Half-Way Covenant debates in 1662-63, the efforts put forward by Indians interested in Eliot's project to form a covenanted church become especially relevant. As puritans struggled to solve the question of transferring faith to subsequent generations, they settled on the notion of a "spiritual lineage" formed by the covenant which children initially entered at birth. As they aged, religious instruction would produce the spiritual fruits necessary for transformation and these halfway members would "own the covenant" when they came of age. At a fundamental level, the mechanism driving this new model of spiritual conversion was rooted in efforts by Indians to demonstrate the efficacy of their preparation and progress. Unbeknownst to all, this notion of spiritual lineages as contained in the covenant served as the groundwork for theological understandings of differences between Indians and Englishmen that matured in the eighteenth century.

While early exploratory accounts stressed indigenous barbarity in comparison to English civility and true religion, King Philip's War served as a crucial turning point that cemented 
understandings of difference in the minds of most Englishmen. Though the Praying Indians' most ardent supporters - John Eliot and Daniel Gookin - continued to intervene on their behalf during the war, the puritans' typological understanding of the conflict drew new connections between biblical archetypes and Indians. Cast as the instruments of God's punishing wrath to be levied against colonists for their failings, or as agents of the Devil bent on sabotaging God's work within the colony, the resulting ideological shift proved devastating to Indians on the continent. While Indian Christians persisted as individuals and communities beyond wartime, they appeared committed to an Indian-centered form of religiosity only peripherally interested in English meddling, especially so with the deaths of Eliot and other members of the earlier puritan generation. Indian Christians continued to serve in wartime capacities as Praying Indian volunteers did during King Philip's War when the geopolitical animosity between France and England continued unabated into the eighteenth century. While individual relations certainly changed the minds of some New Englanders, the prevailing spirit within the colony appears much more rancorous.

Early eighteenth-century theological developments provided new opportunities for Indians to engage Englishmen, demonstrating once again the flexible utility of theology in bridging cultural gaps. Continuing the development in puritan understandings of conversion and community, Solomon Stoddard took the Half-Way Covenant innovations to their logical extreme, opening the sacrament of communion to all who were professing members of the church. This inability to fully resolve the question of "visible sainthood" proved important in the context of Indian Christians and missionary work. By more fully emphasizing the gradual process of sanctification and the utility of a widened concept of ecclesiastical community, the implications of Stoddard's theology were not lost on missionaries like Experience Mayhew and 
early evangelicals like Stephen Williams. This serves as a partial answer to the question of why Indian engagement with Christianity predated the revivalist movement to a certain degree. At the same time, the religious underpinnings that justified and encouraged emergent concepts of theological racism worked to impose boundaries on revivalism's extremes.

If the spirit of revivalism encouraged a number of "New Lights" like David Brainerd to launch missions to western Indian communities and to renew interest in Eliot's original project, the antirevivalist polemic sought to mitigate more radical expansions of ecclesiastical community. That missionaries went to great pains to emphasize the order and sober emotional responses of Indians demonstrates the conscious effort to avoid associations with antirevivalists' strongest criticisms. By presenting revivalism as a degenerative descent into spiritual chaos and disorder, ministers like Charles Chauncy subconsciously drew on colonial anxieties regarding the origins of the continent's indigenous inhabitants. These attacks also served to reinforce emergent categories of theological difference which only intensified in the following decades. By the 1760s, a fully developed concept of Indians as "poor, benighted Pagans" had become common cultural and linguistic currency among Englishmen, including those nominally or intimately devoted to missionary work. This concept held Indians in low theological esteem and posited that only the most exceptional cases like Samson Occom and Joseph Johnson were likely to become true Christians. Even then, the exceptional standards for visible sainthood held against Occom and other Indian Christians served as a means of social control and a dubious cultural safeguard. In cases of disagreement or resentment, which likely led Occom and many other Indian Christians to embrace alcohol as they chafed under these theological double-standards, ministers could disavow and distance themselves from these uncomfortable situations by falling back on the cultural script of Indians' innate paganism. 
Though separated by time and grounded in divergent cultural conditions, Samson Occom and Praying Indians like Waban asserted their place within a shared ecclesiastical community in efforts to bridge the cultural gap that separated them from Englishmen. Drawing on religious culture, with its millennial eschatology and notion of shared humanity, this represented a powerful means by which Indians in North America could approach Englishmen on an unstable "middle ground" of religion forged by the recognition of their shared humanity. While many Englishmen actively harnessed religious culture in efforts to exclude Indians or to justify behavior which modern readers observe with horror or indignation, John Eliot, Daniel Gookin, Solomon Stoddard, and Experience Mayhew stand out as Englishmen who were willing to imagine alternative forms of spiritual brotherhood, which stand in stark contrast to the prevailing theological tendencies of their respective days. This flexible thinking served them well in generating interest among Indians and enabled them to open up religious spaces that provided fleeting comfort and meaning to Indian Christians in the face of colonialism. Taking elements of Christianity and appropriating them within an indigenous cosmological and mental framework, Indian Christians continued to persist in the face of terrible pressures. It is no surprise then that Samson Occom chose to emphasize the commonality of suffering embodied in the life of Christ and the drudgery and hardships of a life waiting for heavenly reward as spiritual messages which resonated with Native Americans' lived circumstances. ${ }^{14}$

\footnotetext{
${ }^{14}$ Two hymns in particular stand out from his Choice Collection of Hymns and Spiritual Songs (1774), namely "The Suffering of Christ," Or, "Throughout the Saviour's Life We Trace” and "The Slow Traveller," Or, "O Happy Souls How Fast You Go," in Joanna Brooks, ed., The Collected Writings of Samson Occom, Mohegan: Leadership and Literature in Eighteenth-Century Native America (Oxford: Oxford University Press, 2006), 234-35. While religious divisions demarcated colonial spheres, Nicholas Canny argues that proselytization followed economic and political goals and only occurred when sufficient moral concern was raised alongside the extension of European government to enforce evangelistic goals. Nicholas Canny, "A Protestant or Catholic Atlantic World? Confessional Divisions and the Writing of Natural History," Proceedings of the British Academy 181 (2012), 83-86, 118-120.
} 
Carla Gardina Pestana argues that religion serves as the one consistent cultural element which shaped early America and the history of colonialism. ${ }^{15}$ By grounding this dissertation in an exploration of colonial theology, English and Indian action, and the changing nature of religious discourse as it pertained to Native Americans this dissertation similarly affirms the importance of colonial theology as an element of religious culture and change. Renewed interest in religious history and the shaping power of historical events on religious ideology is applicable today, as religiosity still serves as a dynamic aspect of many Americans' lives. The recent 2014 Pew Religious Landscape Study has sparked an interesting discourse on American religiosity as it demonstrated a marked rise of "nones": people who fall within a wide spectrum, which ranges from outright atheism to those who simply do not identify with an organized congregation. At the same time, the Pew study showed that evangelical denominations remained surprisingly constant in their representation, suggesting a stability or migration of people between denominations towards a more fundamentalist position. ${ }^{16}$ Rooted in Calvinist theology and the revivalism of the eighteenth century, this research provides new information on the origins of the movement and its contested relationship with Native Americans. Even today, insularity remains a hallmark of evangelicalism as evangelicals tend to marry within the community, place great emphasis on childhood indoctrination (especially so with the rise of the homeschooling within the community), and, in the case of the Quiverfull movement, produce large families. ${ }^{17}$ A better

\footnotetext{
${ }^{15}$ Carla Gardina Pestana, Protestant Empire: Religion and the Making of the British Atlantic World (Philadelphia: University of Pennsylvania Press, 2009), 1-6.

16 "America's Changing Religious Landscape: Christians Decline Sharply as Share of Population; Unaffiliated and Other Faiths Continue to Grow," Pew Research Center, accessed September 26, 2015, http://www.pewforum.org/2015/05/12/americas-changing-religious-landscape/; "Appendix C: Putting Findings from the Religious Landscape Study into Context," Pew Research Center, accessed September 26, 2015, http://www.pewforum.org/2015/05/12/appendix-c-putting-findings-from-the-religious-landscape-study-into-context/ ${ }^{17}$ Sarah Eekhoff Zylstra, "Pew: Evangelicals Stay Strong as Christianity Crumbles in America," Christianity Today, accessed September 24, 2015, http://www.christianitytoday.com/gleanings/2015/may/pew-evangelicals-stay-strongus-religious-landscape-study.html; Kate Zernike, "And Baby Makes How Many?," New York Times, accessed September 28, 2015: http://www.nytimes.com/2009/02/08/fashion/08bigfam.html
} 
understanding of the historical roots of American evangelicalism is important, especially in the context of modern-day missionary work and religious encounters across varied cultures. Contemporary evangelicals should also be mindful to consider the historical results of their theology when put into practice, drawing on historical precedent to temper their most zealous outpourings.

In the wake of September 11, 2001, American culture has become more and more fixated on Islam and the communal standing of American Muslims within the nation. In a recent statement, 2016 presidential hopeful Ben Carson remarked that a Muslim would not be qualified for the presidency because of the imperative to follow Sharia law. ${ }^{18}$ A poll conducted in the wake of this political gaffe showed that Muslims, professing socialists, and atheists were the least likely to be elected when these labels were associated with candidates and their electability. ${ }^{19}$ Despite the Constitutional injunctive to separate religion and statecraft enshrined within the First Amendment, evangelicals continue to merge the two, making a study of religious culture and the way in which theological ideas shape public discourse regarding community and the inclusion or exclusion of members particularly relevant. The early American example of Indian Christian internment on Deer Island during King Philip's War should similarly inform discussions on the civil rights and status of American Muslims within the nation. While the religious differences between Muslims, Christians, and irreligious communities are real and apparent, this research highlights the ability of some individuals to think flexibly in matters of religion as demonstrated in the colonial past. In an increasingly complex and interconnected post-Enlightenment world, this ability is imperative for religious communities, as the rise of the

\footnotetext{
${ }^{18}$ Allen Rappeport, "G.O.P. Field Wrestles With Questions on Islam and the Presidency, The New York Times, accessed September 24, 2015, http://www.nytimes.com/2015/09/21/us/gop-field-wrestles-with-questions-on-islamand-the-presidency.html

${ }^{19}$ Frank Newport, "Six in 10 Americans Would Say 'Yes' to Muslim President," Gallup, accessed September 24, 2015, http://www.gallup.com/opinion/polling-matters/185813/six-americans-say-yes-muslim-president.aspx
} 
Islamic State's fundamentalist form of Islam in the Middle East amply demonstrates the modern paradigm of an expanding yet narrow sectarian vision willing to utilize violence to achieve its objectives.

Generational change and the real and imagined nature of continuity remain the mainstays of religion and religious thought. Even today, some millenarians await the presumed end of the world, drawing eschatological significance from a recent series of lunar eclipses and events. ${ }^{20}$ Reformed evangelicals continue to insist, as they did in the puritans' day, that they practiced the primitive, authentic form of Christianity - or a close approximation of it - derived from the Apostolic Age. At the same time, a growing Calvinist resurgence within American evangelicalism makes the historical study of Calvinists in the colonial period particularly relevant for both the religious and irreligious. ${ }^{21}$

Regardless of these constants, changing circumstances and future uncertainties force every generation to reinterpret and redefine the parameters of religious community. Religious individuals should take heed of this fact and remain acutely aware of the circumstantial nature of religious developments. This dissertation demonstrates the contested nature of colonial theology as a process shaped by various temporal and ideological forces. It also traces the boundary lines of the imagined community formed by Puritan religious thought. While this served to bridge cultural gaps at various times and in differing circumstances, in the end the prevailing

\footnotetext{
${ }^{20}$ Contemporary fixation for millenarians lies with John Hagee's Four Blood Moons: Something is About to Change (2013) and the notion that a tetrad of four lunar phenomenon holds eschatological significance. The popularity of Tim LaHaye and Jerry B. Jenkins' Left Behind series of novels and the Y2K fears of 1999 demonstrate the staying power of millennial thought. Todd Leopold, "Blood moon has some expecting end of the world," $C N N$, accessed September 28, 2015, http://www.cnn.com/2015/09/01/living/blood-moon-biblical-prophecy-feat/; Frederick J. Baumgartner's survey of millennialism through 1999 suggests that this remains one of the dominant trends of Christian thought from the time of the earliest writings to the modern period. Central also to this strain of thought is the responsive tendency towards confronting sweeping social change and the flexibility to rethink social arrangements, which this dissertation similarly demonstrates regarding Indians. Frederick J. Baumgartner, Longing For the End: A History of Millennialism in Western Civilization (New York: St. Martin's Press, 1999), 1-30, 253-64. ${ }^{21}$ Mark Oppenheimer, "Evangelicals Find Themselves in the Midst of a Calvinist Revival," New York Times, accessed September 28, 2015: http://www.nytimes.com/2014/01/04/us/a-calvinist-revival-forevangelicals.html? $\mathrm{r}=0$
} 
counterweight of exclusion served to marginalize Indians, excising them from most forms of ecclesiastical community and justifying their imperiled circumstances. Entering the early republic, Indian Christians like Samson Occom pioneered their own community redefinitions which centered on an inward-facing vision of Indian moral reform and ethnogenesis. Similarly, this work calls attention to the human side of religious belief and practice, as people in the colonial period worked out the application and "lived" nature of their respective theological platforms in the context of various forces at work. It also centers on the human experience of encountering people unlike one's self and the weight of religious belief and theology in attempting to order and define these moments. Facing both outward and inward, Indian and Englishmen defined the parameters of community based on spiritual kinship with conscious attention to those included and excluded from shared religious spaces and membership. 


\section{Appendix A}

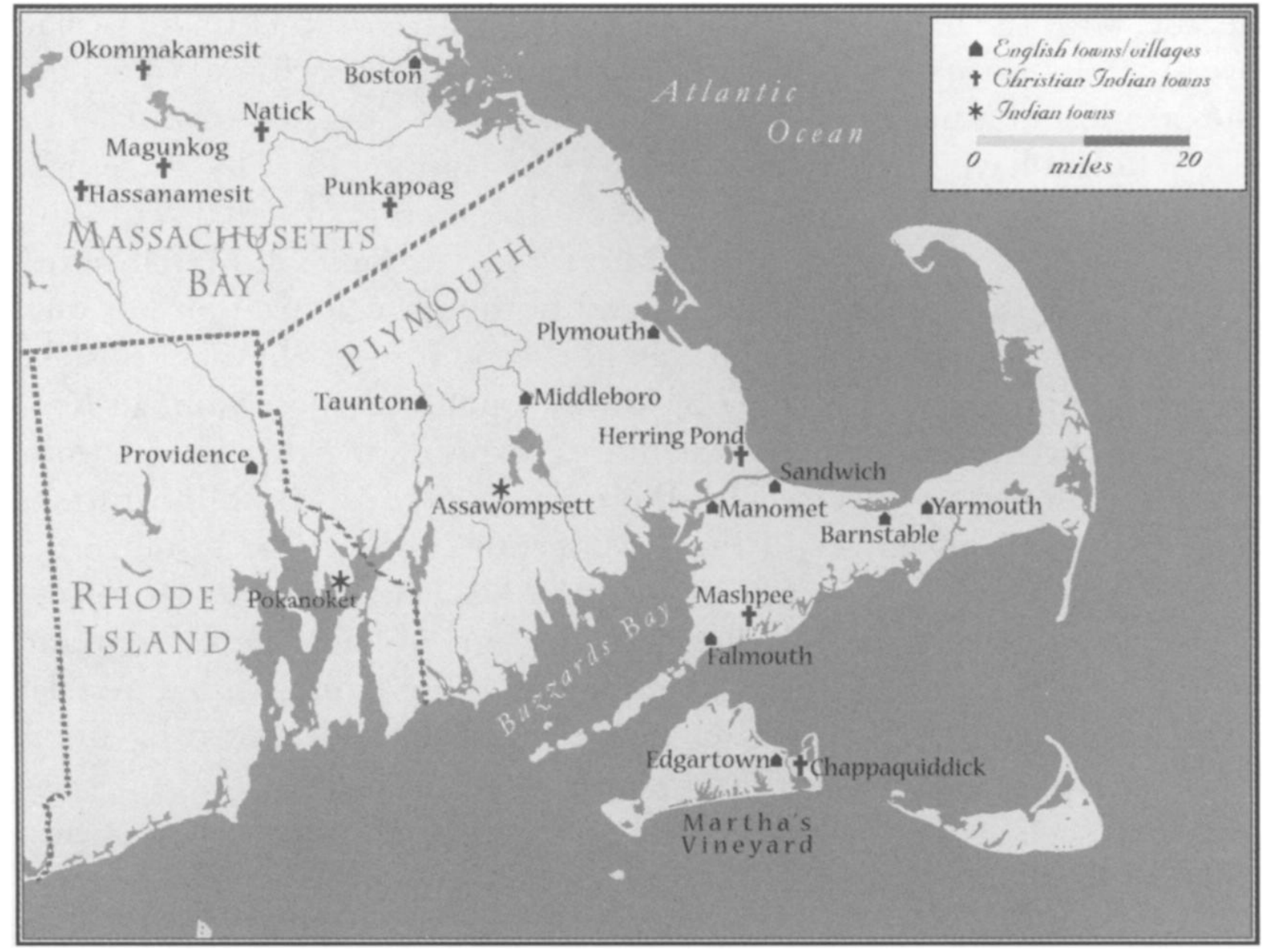

Missions in New England, c. 1666. From J. Patrick Cesarini, "John Eliot's 'A Breif History of the Mashepog Indians,' 1666," The William and Mary Quarterly 65 (2008), 106. 


\section{Appendix B: Colonial-Era Maps}

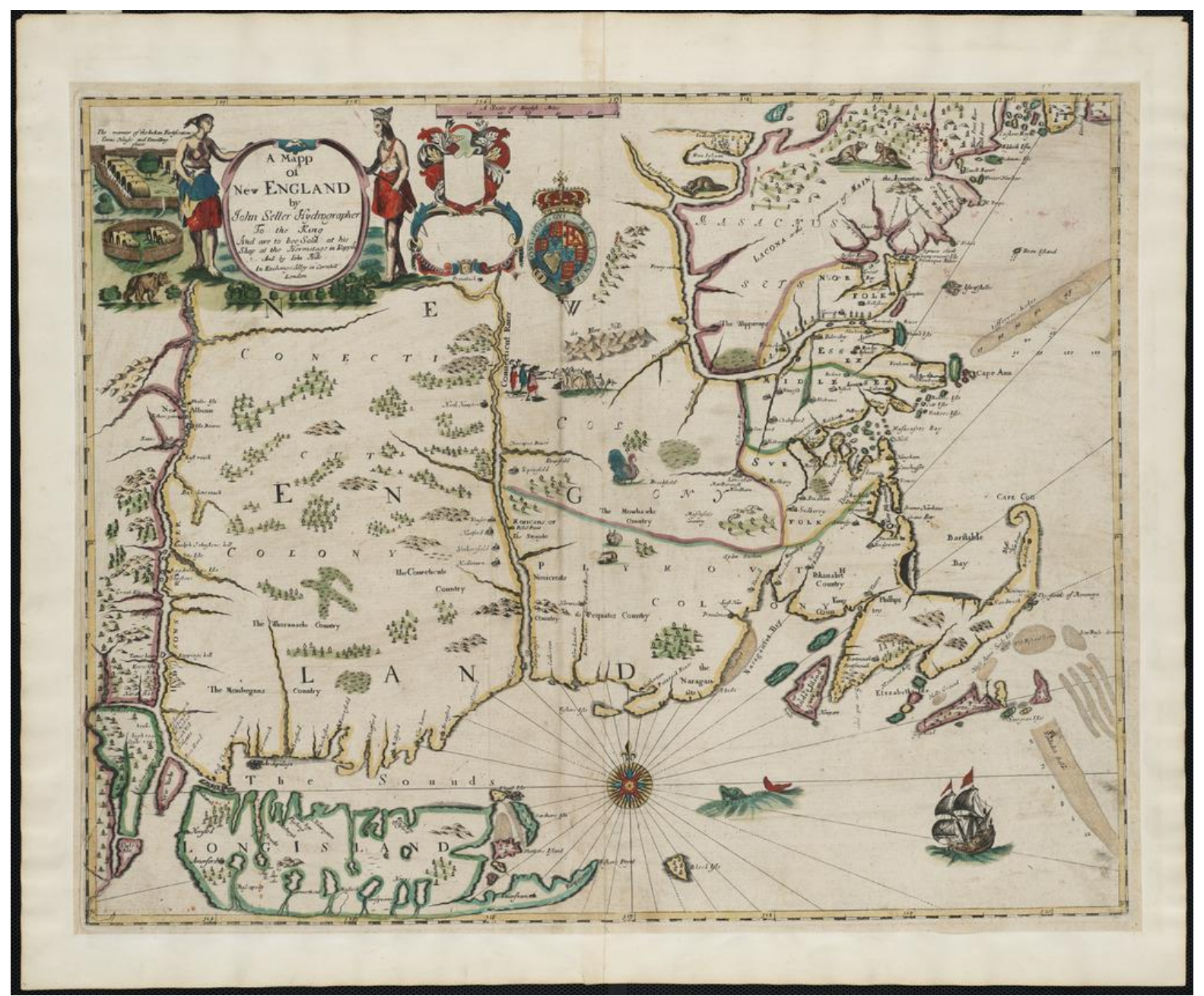

Map 1. John Sellers, “A mapp of New England." 1675. Norman B. Leventhal Map Center at the Boston Public Library. http://maps.bpl.org/id/10058 


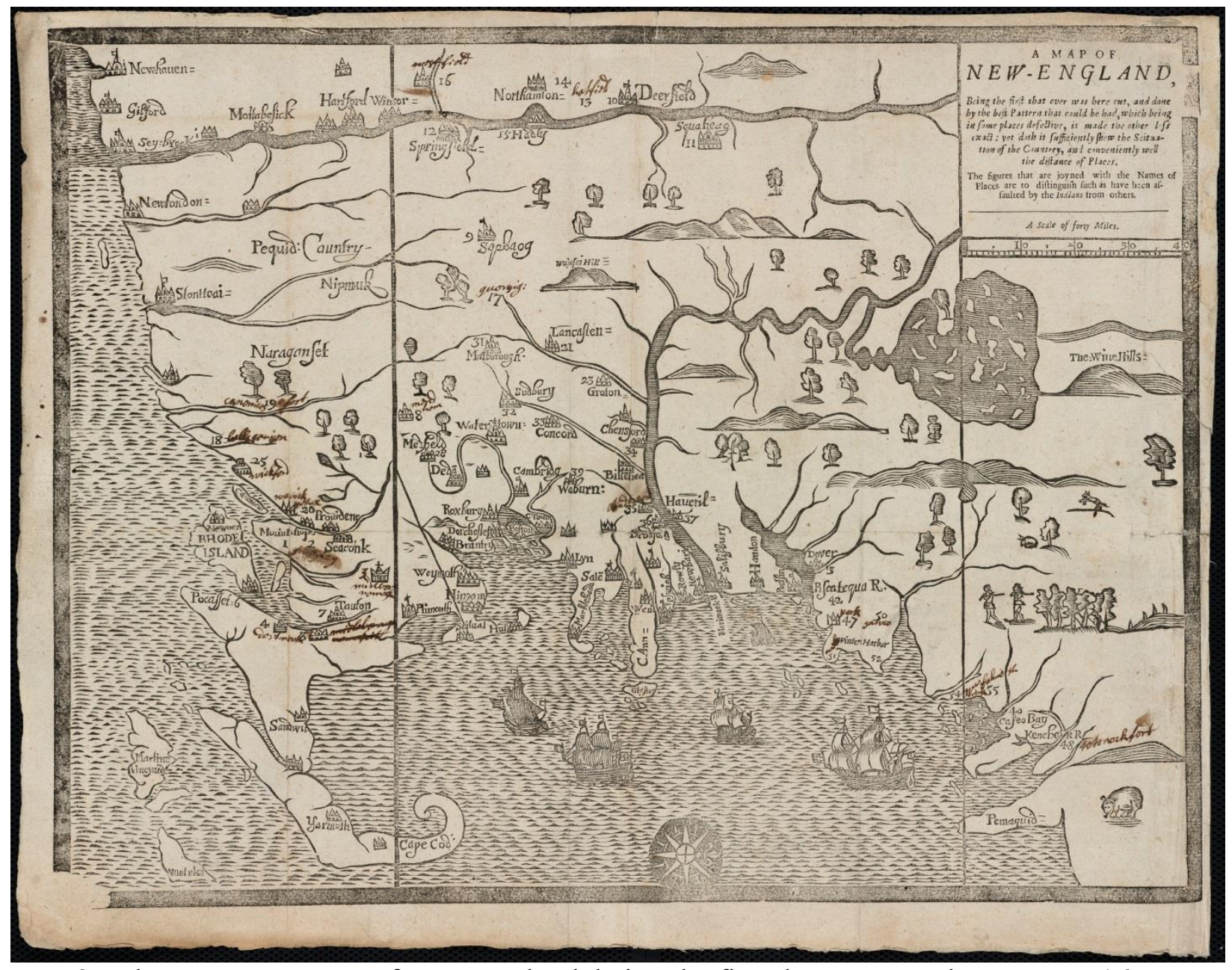

Map 2. John Foster, "A map of New-England, being the first that ever was here cut..." 1677. Norman B. Leventhal Map Center at the Boston Public Library. http://maps.bpl.org/id/10060 


\section{Bibliography}

\section{Archives and Manuscript Collections}

Boston, Massachusetts. Collections of the Massachusetts Historical Society.

Boston, Massachusetts. Miscellaneous Bound Manuscripts. The Massachusetts Historical Society.

Boston, Massachusetts. The Massachusetts Historical Society.

Boston, Massachusetts. The Massachusetts State Archives.

Boston, Massachusetts. The New England Historic \& Genealogical Society.

Chicago, Illinois. Edward E. Ayer Collection. The Newberry Library.

London, United Kingdom. Richard Baxter Papers. Dr. Williams’ Library.

London, United Kingdom. Robert Boyle Papers. The Royal Society.

Providence, Rhode Island. The John Carter Brown Library.

\section{Printed Primary Sources}

1599 Geneva Bible: The Holy Scriptures Contained in the Old and New Testaments. White Hall: Tolle Lege Press, 2007.

A Cry From the Wilderness: Or, A Converted Indian's Address to a Xn. Congregation. Norwich, 1767.

A Revelation of Mr. Brightmans' Revelation, Wherein Is shewed, how all that which Mr. Brightman on the Revelation, hath fore-told concerning Germany, Scotland, and England, hath beene fulfilled, and is yet a ful-filling, comparing his writings, and our Times together. London, 1641.

Allin, John. Animadversions Upon the Antisynodalia Americana, A Treatise Printed in Old England: In the Name of the Dissenting Brethren In the Synod held at Boston in New England 1662. Cambridge, 1664.

-------., The Spouse of Christ Coming out of affliction, leaning upon Her Beloved. Cambridge, 1672.

Ames, William. The Marrow of Theology [1629], John Dykstra Eusden, trans. from Third Latin Edition, The Marrow of Theology: William Ames (1576-1633). Grand Rapids: Baker Books, 1997. 
An Essay, Towards Propagating the Gospel, among the Neighbouring Nations of Indians, In North-America. Submitted, To the Consideration, and proper Endeavours of Rulers, Teachers, and Christians of all Denominations. By a Friend to Church, and Commonwealth. New London, 1756.

Appleton, Nathaniel. How God wills the Salvation of all Men; and their coming to the Knowledge of the Truth, as the Means thereof. Illustrated in a Sermon From 1 Tim. ii. 4. Preached in Boston, March 27, 1753. at the Ordination of the Rev. Mr. Stephen Badger, as a Missionary with a special Reference to the Indians at Natick. Boston, 1753.

Bailey, John. An oration, in celebration of American independence, pronounced at Natick, July 5,1824 , before the officers of the regiment militia, comprising the towns of Natick, Farmingham, Hopkinton, Holliston, and Sherburn. Dedham, 1824.

Baldwin, Thomas W. Vital Records of Natick Massachusetts, To the Year 1850. Boston, 1910.

Bowden, Henry W. and James P. Ronda, eds. John Eliot's Indian Dialogues: A Study in Cultural Interaction. Westport: Greenwood Press, 1980.

Bradford, William. Of Plymouth Plantation, Harvey Wish, ed. New York: Capricorn Books, 1962.

Brightman, Thomas. A Revelation of the Revelation that is... The Revelation of St. John opened clearly with a logicall Resolution and Exposition. Amsterdam, 1615.

Brooks, Joanna, ed. The Collected Writings of Samson Occom, Mohegan: Leadership and Literature in Eighteenth-Century Native America. Oxford: Oxford University Press, 2006.

Buell, Samuel. The Excellency and Importance of the Saving Knowledge of the Lord Jesus Christ in the Gospel-Preacher, plainly and seriously represented and enforced: And Christ preached to the Gentiles in Obedience to the Call of God. A Sermon, Preached at EastHampton, August 29, 1759; At the Ordination of Mr. Samson Occum, A Missionary among the Indians. New York, 1761.

Byles, Mathers. A Sermon on the Nature and Necessity of Conversion. Boston, 1769.

Clark, Michael P., ed. The Eliot Tracts: With Letters from John Eliot to Thomas Thorowgood and Richard Baxter. Westport: Praeger Publishers, 2003.

Chauncy, Charles. All Nations of the Earth blessed in Christ, the Seed of Abraham. A Sermon Preached at Boston, At The Ordination of the Rev. Mr. Joseph Bowman, To the Work of the Gospel-Ministry, More especially Among the Mohawk-Indians, on the Western Borders of New-England. Boston, 1762. 
-------, Enthusiasm described and caution'd against. A Sermon Preach'd at the Old Brick Meeting-House in Boston, the Lord's Day after the Commencement, 1742. WSith a Letter to the Reverend Mr. James Davenport. Boston, 1742.

------., Seasonable Thoughts on the State of Religion in New-England, A Treatise in five Parts. Boston, 1743.

Cotton, John. The Keys of the Kingdom of Heaven and The Way of Congregational Churches Cleared. Weston Rhyn: Quinta Press, 2008.

Davenport, James. Meditations on Several Divine Subjects: I. On the Humanity of CHrist. II. The Extensiveness of God's good Design in Selling Joseph into Egypt. III. Christ the King sitting at his Table. IV. Of the Love of Christ, and saving Knowledge of it. With A Letter to a Friend, about the Affairs of his Soul. By a Person unhappily taken off from his Ministry by bodily Disorders. Boston, 1748.

Davenport, John. Another Essay for Investigation of the Truth, in Answer to Two Questions, concerning (a) The subject of Baptism. (b) The Consociation of Churches. Cambridge, 1663.

Danforth, Samuel. A Brief Recognition of New-Englands Errand Into The Wilderness. Cambridge, 1669.

Dwight, Timothy. The Conquest of Canäan; A Poem, In Eleven Books. Hartford, 1785.

Edwards, Jonathan, ed. The Life and Diary of David Brainerd. Peabody: Hendrickson Publishers, 2006.

Eliot, John. The Christian Commonwealth: Or, The Civil Policy of The Rising Kingdom of Jesus Christ. London, 1659.

Ford, John W., ed. Some Correspondence Between the Governors and Treasurers of the New England Company in London and the Commissioners of the United Colonies in America, the Missionaries of the Company and Others Between the Years 1657 and 1712 to Which Are Added the Journals of the Rev. Experience Mayhew in 1713 and 1714. New York: Burt Franklin, 1970.

Foster, John. "A map of New-England, being the first that ever was here cut..." 1677. Norman B. Leventhal Map Center at the Boston Public Library. http://maps.bpl.org/id/10060

Frost, Amariah. The Substance of Two Sermons, One on the total Depravity of human Nature, while unrenewed; from Gen. 6. 5. The other from Gal. 6. 15. Being a Description of the New Creature. Delivered at Westborough, Dec. 8. 1765. Boston, 1766.

Goddard, Ives and Kathleen Bragdon, eds. Native Writings in Massachusett, I. Philadelphia: The American Philosophical Society, 1988. 
Gookin, Daniel. An Historical Account of the Doings and Sufferings of The Christian Indians in New England, in the Years 1675, 1676, 1677 Impartially Drawn by One Well Acquainted With That Affair, and Presented Unto the Right Honorable The Corporation Residing in London, Appointed By the King's Most Excellent Majesty for Promoting the Gospel Among the Indians in America, in Archoologia Americana: Transactions and Collections of the American Antiquarian Society, Vol. II. Cambridge, 1836.

-------., Historical Collections of the Indians in New England. Of Their Several Nations, Numbers, Customs, Manners, Religion and Government, Before the English Planted There. Collections of the Massachusetts Historical Society, I:I. Boston, 1792.

Hakluyt, Richard. Voyages and Discoveries: The Principal Navigations, Voyages, Traffiques and Discoveries of the English Nation, Jack Beeching, ed. London: Penguin Books, 1985.

Hancock, John. The Examiner, Or Gilbert against Tennent. Philadelphia, 1743.

Harris, J. Rendel. Three Letters of John Eliot and a Bill of Lading of the Mayflower. Reprinted from "The Bulletin of the John Rylands Library Vol. 5, Nos. 1 and 2, August, 1918March, 1919.” Printed for Private Circulation, 1919.

Higginson, John. The Cause of God and His People in New-England. Cambridge, 1663.

Holyoke, Edward. The Duty of Ministers of the Gospel to guard against the Pharisaism and Sadducism of the present Day. Sherewd in a Sermon Preach'd to the Convention of Ministers of the Province of the Massachusetts-Bay, N.E. at Boston, ON Thursday, May 28. 1741. Boston, 1741.

Hopkins, Samuel. An Address to the People of New-England. Representing The very great Importance of attaching the Indians to their Interest; not only by treating them justly and kindly; but by using proper Endeavours to settle Christianity among them. Boston, 1753.

-------., Historical Memoirs, Relating to the Housatonic Indians By Rev. Samuel Hopkins (16931755). New York, 1911.

Hooker, Samuel. Righteousness Rained from Heaven, Or A Serious and Seasonable Discourse Exciting all to an earnest enquiry after, and continued waiting for the effusions of the Spirit, unto a communication and increase of Righteousness: That Faith, Holiness, and Obedience may yet abound among us, and the Wilderness become a fruitful field, As it was Delivered in a Sermon Preached at Hartford on Connecticut in New-England, May 10. 1677. Being the Day of Election there. Cambridge, 1677.

Hubbard, William. A Narrative of the Troubles with the Indians In New-England, from the first planting thereof in the year 1607. to this present year 1677. But chiefly of the late Troubles in the two last years, 1675 and 1676. To which is added a Discourse about the Warre with the Pequods In the year 1637. Boston, 1677. 
-------., The Happiness of a People In the Wisdome of their Rulers Directing and in the Obedience of their Brethren Attending Unto what Israel ought to do: Recommended in a Sermon Before the Honourable Governour and Council, and the Respected Deputies of the Massachusetts Colony in New-England. Preached at Boston, May 3d. 1676. Being the day of Election there. Boston, 1676.

Johnson, Edward. Wonder-Working Providence of Sions Saviour in New-England (1654) and Good News From New England (1648). New York: Scholars' Facsimiles \& Reprints, 1974.

Johnson, Joseph. Letter from J---h J----n, one of the Mohegan Tribe of Indians, to his Countryman, Moses Paul, under Sentence of Death, in New-Haven Goal. New London, 1772.

Josselyn, John. An Account of Two Voyages to New-England, Made during the years 1638, 1663 By John Josselyn Gent. Boston, 1865.

Leibman, Laura Arnold, ed. Experience Mayhew's Indian Converts: A Cultural Edition. Amherst: University of Massachusetts Press, 2008.

Mather, Cotton. An Epistle to the Christian Indians, Giving them A Short Account, of what the English Desire them to Know and to Do, In order to their Happiness. Written by an English Minister, at the Desire of an English Magistrate, who sends unto them this Token of Love. Boston, 1706.

-------., Another Tongue brought in, to Confess the Great Saviour of the World. Or, Some Communications of Christianity, Put into a Tongue used among the Iroquois Indians, in America. And, Put into the Hands of the English and Dutch Traders: To accommodate the Great Intention of Communicating the Christian Religion, unto the Salvages, among whom they may find any thing of this Language to be Intelligible. Boston, 1707.

------., Bonifacius. An Essay Upon the Good, that is to be Devised and Designed, By Those Who Desire to Answer the Great End of Life, and to Do Good While they Live. A Book Offered, First, in General, unto all Christians, in a Personal Capacity, or in a Relative. Then more Particularly, Unto Magistrates, unto Ministers, unto Physicians, unto Lawyers, unto Scholemasters, unto Wealthy Gentlemen, unto several Sorts of Officers, unto Churches, and unto all Societies of a Religious Character and Intention With Humble Proposals, of Unexceptional Methods, to Do Good in the World. Boston, 1710.

-------., India Christiana. A Discourse, Delivered unto the Commissioners, For The Propagation of the Gospel among the American Indians Which Is Accompanied with several Instruments relating to the Glorious Design of Propagating our Holy Religion, in the Eastern as well as the Western, Indies. An Entertainment which they that are Waiting for the Kingdom of God will receive as Good News from a far Country. Boston, 1721. 
-------, Soldiers Counselled and Comforted: A Discourse Delivered unto some part of the Forces Engaged in the Just War of New-England Against the Northern \& Eastern Indians. Boston, 1689.

Mather, Eleazar. A Serious Exhortation to the Present and Succeeding Generation in NewEngland. Cambridge, 1671.

Mather, Increase. A Brief History of the Warr With the Indians in New-England. Boston, 1676.

-------., A Dissertation, Wherein The Strange Doctrine Lately Published in a Sermon, The Tendency of which, is, to Encourage Unsanctified Persons (while such) to Approach the Holy Table of the Lord, is Examined and Confuted. With an Appendix, Shewing What Scripture Ground there is to Hope, that within a very few years there will be a Glorious Reformation of the Church throughout the World. Boston, 1708.

-------., A Letter, About the Present State of Christianity, among the Christianized Indians of New-England. Written, To the Honourable, Sir William Ashhurst, Governour of the Corporation, for Propagating the Gospel among the Indians, in New-England, and Parts Adjacent, in America. Boston, 1705.

-------., A Plain Discourse, Shewing Who shall, \& who shall not, Enter into the Kingdom of Heaven, and How far Men may go and yet fall short of Heaven, after their seeming to be Converted and Religious. Boston, 1713.

------., An Historical Discourse Concerning the Prevalency of Prayer Wherein is shewed that New-Englands late Deliverance from the Rage of the Heathen, is an eminent Answer of Prayer. Boston, 1677.

-------., Awakening Truth's Tending to Conversion. Delivered In several Sermons Wherein is Shewed, I. That the greatest Sinners may be Converted and Saved. II. That sinners who cannot Convert themselves, ought to Pray for Converting Grace. III. That Sinners who neglect Spiritual Blessings until the Day of Grace is past, will wish for them but in vain, when it is too late. In which SERMONS notice is taken of some late Remarkable Conversions. Boston, 1710.

-------., Renewal of Covenant the great Duty incumbent on decaying or distressed Churches. A Sermon Concerning Renewing of Covenant with God in Christ, Preached at Dorchester in New-England, the 21. Day of the 1. Moneth 1677. being a Day of Humiliation There, on that Occasion. Boston, 1677.

-------, The Day of Trouble is Near. Two Sermons Wherein is shewed. What are the Signs of a Day of Trouble being near. And particularly, What reason there is for New-England to expect A Day of Trouble. Also what is to be done, that we may escape these things which shall come to pass. Cambridge, 1674. 
Mather, Richard. A Defence of the Answers and Arguments of the Synod Met at Boston in the Year 1662. Cambridge, 1664.

-------., A Farewel Exhortation to the Church and People of Dorchester in New-England. Cambridge, 1657.

------., Church Government and Church Covenant Discussed. Weston Rhyn: Quinta Press, 2008.

Mayhew, Experience. A Discourse Shewing that God Dealeth with Men As with Reasonable Creatures In a Sermon Preach'd at Boston, N.E. Nov. 23. 1718. With a brief account of the State of the Indians on Martha's Vineyard, \& the Small Island adjacent in Dukes County, from the Year 1694 to 1720. Boston, 1720.

------., A Letter To a Gentleman On that Question, Whether Saving Grace be different in Species from Common Grace, or in Degree only? Boston, 1747.

-------., A Right to the Lord's Supper Considered in A Letter to A serious Enquirer after Truth. By A Lover of the same. Boston, 1741.

------., All Mankind, by Nature, Equally under Sin. A Sermon Preach'd at The Public Lecture in Boston. On Thursday, Dec. 3. 1724. Boston, 1725.

-------., Grace Defended, In A Modest Plea for an Important Truth; Namely, That the Offer of Salvation made to Sinners in the Gospel, comprises in it an Offer of the Grace given in Regeneration. And Shewing the Consistency of this Truth with the Free and Sovereign Grace of God, in the whole Work of Man's Salvation. In Which the Doctrine of Original Sin and Human Impotence, the Object and Extend of Redemption, the Nature of Regeneration, the Difference between Common and Special Grace, the Nature of justifying Faith, and other Important Points, are considered and cleared. Boston, 1744.

Mayhew, Jr., Thomas. "The Glorious Progress of the GOSPEL, amongst the Indians in New England." [1649] In The Eliot Tracts: With Letters from John Eliot to Thomas Thorowgood and Richard Baxter, edited by Michael P. Clark, 141-167. Westport: Praeger Publishers, 2003.

-------, "The Light appearing more and more towards the perfect Day." [1651] In The Eliot Tracts: With Letters from John Eliot to Thomas Thorowgood and Richard Baxter, edited by Michael P. Clark, 169-209. Westport: Praeger Publishers, 2003.

McCallum, James Dow, ed. The Letters of Eleazar Wheelock's Indians. Hanover: Dartmouth College Publications, 1932.

McGiffert, Michael, ed. God's Plot: Puritan Spirituality in Thomas Shepard's Cambridge. Amherst: University of Massachusetts Press, 1994.

Morton, Thomas. New English Canaan. Publications of the Prince Society. Boston, 1883. 
Niles, Samuel. Tristitiae Ecclesiarum: Or, A brief and sorrowful Account of the Present State of the Churches in New-England: In a Letter From a Minister in the Country to the Publick. Wherein is contained, Some Remarks on the Rise, Progress, and unhappy Effects of the different Sentiments among Us at this Day in Matters of Religion. To which is added by Way of Advice Some healing Measures. With an Appendix. Boston, 1745.

Nowell, Samuel. Abraham in Arms, Or The First Religious General With His Army Engaging in A War For which he had wisely prepared, and by which, not only an eminent Victory Was obtained, but A Blessing gained also. Delivered in an Artillery-Election-Sermon, June 4. 1678. Boston, 1678.

O'Connell, Barry, ed. On Our Own Ground: The Complete Writings of William Apess, a Pequot. Amherst: University of Massachusetts Press, 1992.

Occom, Samson. A Sermon, Preached at the Execution of Moses Paul, An Indian. Who was executed at New-Haven, on the Second of September, 1772; for the Murder of Mr. Moses Cook, late of Water-bury, on the $7^{\text {th }}$ of December, 1771. Preached at the Desire of said Paul. New Haven, 1772.

Oxenbridge, John. A Quickening Word For The hastening a Sluggish Soul to a seasonable Answer to The Divine Call. Cambridge, 1670.

-------., A Seasonable Proposition of Propagating the Gospel by Christian Colonies in the Continent of Guaiana: Being Some Gleanings of a Larger Discourse Drawn, But Not Published. London, 1670.

------., New-England Freemen Warned and Warmed, To be Free indeed, having an Eye to God in their Elections. Cambridge, 1673.

Peabody, Oliver. The Foundations, Effects, and distinguishing Properties of a good and bad Hope of Salvation; with Motives to excite all to labour and pray that they may obtain a well-grounded Hope, and some Directions how to obtain it. Considered in a Sermon, The Substance of which was delivered at the Evening-Lecture at the New-North Church in Boston, on Tuesday June $8^{\text {th }} 1742$. Where a Copy of it was desired for the Press. Boston, 1742.

Peirson, Abraham. Some Helps for the Indians Shewing Them How to improve their natural Reason, To know the True GOD, and the true Christian Religion. Cambridge, 1659.

Pilkington, Walter, ed. The Journals of Samuel Kirkland: $18^{\text {th }}$-century Missionary to the Iroquois, Government Agent, Father of Hamilton College. Clinton: Hamilton College, 1980. 
Report By a Committee of the Corporation Commonly Called the New England Company, of Their Proceedings, for the Civilization and Conversion of Indians, Blacks, and Pagans, in the British Colonies in America, and the West Indies, since the Last Report in 1832. London, 1840.

Richardson, John. The Necessity of a Well Experienced Souldiery: Or, A Christian Common Wealth ought to be well Instructed \& Experienced in the Military Art. Cambridge, 1679.

Richardson, Leon Burr, ed. An Indian Preacher In England: Being Letters and Diaries Relating to the Mission of the Reverend Samson Occom and the Reverend Nathaniel Whitaker to Collect Funds in England for the Benefit of Eleazar Wheelock's Indian Charity School, From Which Grew Dartmouth College. Hanover: Dartmouth College Publications, 1933.

Rowlandson, Joseph. The Possibility of Gods Forsaking a people, That have been visibly near \& dear to him... Set forth in a Sermon, Preached at Weathersfield, Nov. 21. 1678. Cambridge, 1678.

Salisbury, Neal, ed. The Sovereignty and Goodness of God by Mary Rowlandson with Related Documents. New York: Bedford/St. Martin's, 1997.

Sellers, John. "A map of New England." 1675. Norman B. Leventhal Map Center at the Boston Public Library. http://maps.bpl.org/id/10058

Sergeant, John._The Causes and Danger of Delusions In the Affairs of Religion, Consider'd and caution'd against, With particular Reference to the Temper of the present Times. In a Sermon Preach'd at Springfield, April 4. 1743. In the Audience of the associated Pastors of the County of Hampshire. Boston, 1743.

Shepard, Thomas. The Church Membership of Children and their Right to Baptisme. Cambridge, 1663.

Shurtleff, William. Gospel Ministers exhibited under the Notion of Stars; and our Lord Jesus Christ as holding these Stars in his right Hand. In a Sermon Preach'd at the Ordination of Mr. Nathaniel Gookin. To the Pastoral Office of a Church at North-Hill in the Town of Hampton, October 31. 1739. Boston, 1739.

Slotkin, Richard and James K. Folsom, eds. So Dreadfull a Judgment: Puritan Responses to King Philip's War 1676-1677. Hanover: University Press of New England, 1978.

Snodgrass, John. Prospects of Providence Respecting the Conversion of the World to Christ: A Sermon, Preached Before the Paisley London Missionary Society, in the High Church of Paisley, On Friday, June 10 ${ }^{\text {th }}$, 1796. With an Appendix, Containing An Account of the Progress and Present State of the Missionary Business. Paisley, 1796. 
Stoddard, Solomon. An Appeal to the Learned. Being A Vindication of the Right of Visible Saints to the Lords Supper, Though they be destitute of a Saving Work of God's Spirit on their Hearts: Against the Exceptions of Mr. Increase Mather. Boston, 1709.

-------., The Inexcusableness of Neglecting the Worship of God, Under A Pretence of being in an Unconverted Condition. Shewed in a Sermon Preached at Northampton, The $17^{\text {th }}$

Decemb. 1707. being the time of the Sitting of the Inferior Court. Boston, 1708.

------., The Tryal of Assurance, Set forth in a Sermon; Preached at Boston upon a Lecture day. July $7^{\text {th }}$. 1698. Boston, 1698.

-------., Question Whether God is not Angry with the Country for doing so little towards the Conversion of the Indians? Boston, 1723.

Styles, Ezra. To the Public, There has been a Design Formed . . . to Send the Gospel to Guinea. Newport, 1776.

Thatcher, Thomas. A Fast of God's chusing, Plainly opened, For the Help of those poor in Spirit, whose hearts are set to seek the Lord their God in New-England, in the solemn Ordinance of A Fast. Boston, 1678.

The Book of Common Prayer, And Administration of the Sacraments, and Other Rites and Ceremonies of the Church, According to the Use of the Church of England: Together with a Collection of Occasional Prayers, and divers Sentences of Holy Scripture, Necessary for Knowledge and Practice. Formerly Collected, and translated into the Mohawk Language under the direction of the Missionaries of the Society for the Propagation of the Gospel in Foreign Parts, to the Mohawk Indians. A New Edition: To Which Is Added The Gospel according to St. Mark, Translated into the Mohawk Language, By Captn. Joseph Brant, An Indian of the Mohawk Nation. London, 1787.

The Conversion of a Mehometan. To the Christian Religion, Described in a Letter From Gaifer, in England. To Aly-Ben-Hayton, his Friend in Turkey, 6 ${ }^{\text {th }}$ edition. New London, 1773.

The Declaration of A Number of the associated Pastors of Boston and Charles-Town relating to the Rev. Mr. James Davenport, and his Conduct. Boston, 1742.

The Declaration of Ministers In Barnstable County, relating to the late Practice of Itinerant Preaching. Boston, 1745.

The Testimony Of an Association of Ministers Convened at Marlborough, Jan. 22. 1744. Against the Reverend Mr. George Whitefield, And his Conduct. As also, The Testimony Of a Number of Ministers in the Country of Bristol, Against the said Gentleman. Boston, 1745. 
The Testimony of The North Association in the County of Hartford, in the Colony of Connecticut, convened at Windsor, Feb. 5. 1744,5. Against the Rev. Mr. George Whitefield and his Conduct. And An Address From some of the Ministers in the County of Hampshire, to the Rev. Mr. George Whitefield. Boston, 1745.

The Testimony of the Pastors of the Churches in the Province of the Massachusetts-Bay in NewEngland, at their Annual Convention in Boston, May 25. 1743. Against several Errors in Doctrine, and Disorders in Practice, Which have of late obtained in various Parts of the Land; as drawn up by a Committee chosen by the said Pastors, read and accepted Paragraph by Paragraph, and voted to be sign'd by the Moderator in their Name, and Printed. Boston, 1743.

The Testimony of the President, Professors, Tutors, and Hebrew Instructor of Harvard College in Cambridge, Against the Reverend Mr. George Whitefield, And his Conduct. Boston, 1744.

Thompson, Benjamin. New Englands Crisis: Or a Brief Narrative, Of New-ENglands Lamentable Estate at present, compar'd with the former (but few) years of Prosparity. Occasioned by many unheard of Crueltyes practicesd upon the Persons and Estates of its united Colonyes, without respect of Sex, Age, or Quality of Persons, by the Barbarous Heathen thereof. Poetically Described. By a Well wisher to his Countrey. Boston, 1676.

Tinker, Reuben. Ought I To Become a Missionary? An Address to Theological Students: By Rev. Reuben Tinker, Missionary to the Sandwich Islands. Dedham, 1831.

Two Letters From the Reverend Mr. Williams \& Wheelock of Lebanon, To The Rev. Mr. Davenport, Which were The principal Means of his late Conviction and Retraction. With A Letter from Mr. Davenport, desiring their Publication, for the Good of others. And His Explanation of some Passages in his late Confession. Boston, 1744.

Vaughan, Alden T., ed. Early American Indian Documents: Treaties and Laws, 1607-1788. Bethesda: University Publications of America, 2004.

Vaughan, Alden T. and Edward W. Clark, eds. Puritans Among the Indians: Accounts of Captivity and Redemption, 1676-1724. Cambridge: Belknap Press, 1981.

Walker, Williston, The Creeds and Platforms of Congregationalism. New York: Charles Scribner's Sons, 1893.

Walley, Thomas. Balm in Gilead to Heal Sions Wounds. Cambridge, 1669.

Wheeler, Thomas. A Thankfull Remembrance of Gods Mercy to several Persons at Quabaug or Brookfield: Partly in a Collection of Providences about them, and Gracious Apperances for them: And partly in a Sermon Preached by Mr. Edward Bulkley, Pastor of the Church of Christ at Concord, upon a day of Thanksgiving, kept by divers for their Wonderfull Deliverence there. Cambridge, 1676. 
Wheelock, Eleazar. A Continuation of the Narrative of the Indian Charity School, Begun in Lebanon, in Connecticut; Now Incorporated with Dartmouth-College, In Hanover, In the Province of New-Hampshire. Portsmouth, 1772.

------., A Continuation of the Narrative of the Indian Charity-School, In Lebanon, In Connecticut; From the Year 1768 to the Incorporation of it with Dartmouth-College, And Removal and Settlement of it in Hanover, In the Province of New-Hampshire, 1771. Hartford, 1771.

-------., A plain and faithful Narrative of the Original Design, Rise, Progress, and present State of the Indian Charity-School At Lebanon, in Connecticut. Boston, 1763.

-------., Continuation of the Narrative of the Indian Charity-School. Begun In Lebanon, In Connecticut; Now Incorporated with Dartmouth-College, In Hanover, in the Province of New-Hampshire. With a Dedication to the Honorable Trust in London. To Which is Added An Account of Missions the last Year, in an Abstract from the Journal of the Rev'd Mr. Frisbie, Missionary. Hartford, 1775.

Willard, Samuel. The Heart Garrisoned OR, The Wisdome, and Care of the Spiritual Souldier above all things to safeguard his Heart. Cambridge, 1676.

Williams, Roger. A Key Into the Language of America: or, An help to the Language of the Natives in that part of America, called New-England. London: Gregory Dexter, 1643.

------., Christenings Make Not Christians (1645), in Rhode Island Historical Tracts No. 14, Henry Martyn Dexter, ed. Providence: Sidney S. Rider, 1881.

Wilson, John. A Seasonable Watch-Word Unto Christians Against the Dreams \& Dreamers Of this Generation: Delivered in a Sermon November $16^{\text {th }}$ 1665. And being the last Lecture, which was Preached By that Reverend, Faithful and Eminent Man of God Mr. John Wilson. Sometime Pastor of the Church of Christ in Boston in New-England. Cambridge, 1677.

Winslow, Edward. "Good News from New England,", in Chronicles of the Pilgrim Fathers of the Colony of Plymouth, From 1602 to 1625. Now First Collected From Original Records and Contemporaneous Printed Documents, and Illustrated With Notes, ed. Alexander Young. Boston: Charles C. Little and James Brown, 1841.

Winthrop, John. Winthrop's Journal “History of New England” 1630-1649, ed. James Kendall Hosmer, Vol. I. New York: Charles Scribner's Sons, 1908.

Wood, William. New England's Prospect. Publications of the Prince Society. Boston, 1865.

Young, Alexander. Christianity Designed and Adapted to Be a Universal Religion. A Discourse Delivered at the Ordination of the Rev. James W. Thompson, As Pastor of the South Congregational Society, In Natick, Feb. 17, 1830. Boston, 1830. 


\section{Secondary Sources: Monographs and Edited Volumes}

Anderson, Benedict. Imagined Communities: Reflections on the Origin and Spread of Nationalism, New Edition. London: Verso, 2006.

Anderson, Fred. The War That Made America: A Short History of the French and Indian War. New York: Penguin Books, 2005.

------., Crucible of War: The Seven Years' War and the fate of Empire in British North America, 1754-1766. New York: Vintage Books, 2000.

Andrews, Edward E. Native Apostles: Black and Indian Missionaries in the British Atlantic World. Cambridge: Harvard University Press, 2013.

Ayer, Mary Farwell. Richard Bourne, Missionary to the Mashpee Indians. Boston: Press of David Clapp \& Son, 1908.

Axtell, James. The Invasion Within: The Contest of Cultures in Colonial North America. Oxford: Oxford University Press, 1985.

Bach, Rebecca Ann. Colonial Transformations: The Cultural Production of the New Atlantic World, 1580-1640. New York: Palgrave, 2000.

Bailey, Richard A. Race and Redemption in Puritan New England. Oxford: Oxford University Press, 2011.

Baumgartner, Frederick J. Longing For the End: A History of Millennialism in Western Civilization. New York: St. Martin’s Press, 1999.

Bell, James B. A War of Religion: Dissenters, Anglicans, and the American Revolution. Houndsmill: Palgrave MacMillan, 2008.

Berger, Peter L. The Sacred Canopy: Elements of a Sociological Theory of Religion. Garden City: Anchor Books, 1967.

Bonomi, Patricia U. Under the Cope of Heaven: Religion, Society, and Politics in Colonial America, Updated Edition. Oxford: Oxford University Press, 2003.

Boulware, Tyler. Deconstructing the Cherokee Nation: Town, Region, and Nation among Eighteenth-Century Cherokees. Gainesville: University Press of Florida, 2011.

Bozeman, Theodore Dwight. To Live Ancient Lives: The Primitivist Dimension in Puritanism. Chapel Hill: University of North Carolina Press, 1988.

Bragdon, Kathleen J. Native People of Southern New England, 1500-1650. Norman: University of Oklahoma Press, 1996. 
------., Native People of Southern New England, 1650-1775. Norman: University of Oklahoma Press, 2009.

Bremer, Francis J. Clerical Communion: Clerical Friendship in the Anglo-American Puritan Community, 1610-1692. Boston: Northeastern University Press, 1994.

-------., Shaping New Englands: Puritan Clergymen in Seventeenth-Century England and New England. New York: Twayne Publishers, 1994.

-------, The Puritan Experiment: New England Society from Bradford to Edwards. New York: St. Martin's Press, 1976.

Bross, Kristina. Dry Bones and Indian Sermons: Praying Indians in Colonial America. Ithaca: Cornell University Press, 2004.

Brown, Matthew P. The Pilgrim and the Bee: Reading Rituals and Book Culture in Early New England. Philadelphia: University of Pennsylvania Press, 2007.

Bryant, M. Darrol. Jonathan Edwards' Grammar of Time, Self, and Society: A Critique of the Heimert Thesis. Lewiston: Edwin Mellen Press, 1993.

Butler, Jon. Awash in a Sea of Faith: Christianizing the American People. Cambridge: Harvard University Press, 1990.

-------, New World Faiths: Religion in Colonial America. Oxford: Oxford University Press, 2008.

Calloway, Colin G. The Scratch of a Pen: 1763 and the Transformation of North America. Oxford: Oxford University Press, 2006.

Campbell, William J. Speculators in Empire: Iroquoia and the 1768 Treaty of Fort Stanwix. Norman: University of Oklahoma Press, 2012.

Chmielewski, Laura M. The Spice of Popery: Converging Christianities on an Early American Frontier. Notre Dame: University of Notre Dame Press, 2012.

Clark, Michael P. "Introduction." In The Eliot Tracts: With Letters from John Eliot to Thomas Thorowgood and Richard Baxter, edited by Michael P. Clark, 1-52. Westport: Praeger Publishers, 2003.

Coalter, Jr., Milton J. Gilbert Tennent, Son of Thunder: A Case Study of Continental Pietism 's Impact on the First Great Awakening in the Middle Colonies. New York: Greenwood Press, 1986.

Cogley, Richard W. John Eliot's Mission to the Indians before King Philip's War. Cambridge: Harvard University Press, 1999. 
Crawford, Michael J. Seasons of Grace: Colonial New England's Revival Tradition in Its British Context. Oxford: Oxford University Press, 1991.

Cray, Robert E. Lovewell's Fight: War, Death, and Memory in Borderland New England. Amherst: University of Massachusetts Press, 2014.

Cronon, William. Changes in the Land: Indians, Colonists, and the Ecology of New England. New York: Hill and Wang, 2003.

Demos, John. The Unredeemed Captive: A Family Story from Early America. New York: Vintage Books, 1994.

Dunn, Richard S. The Age of Religious Wars, 1559-1715, $2^{\text {nd }}$ Edition. New York: W.W. Norton \& Company, 1979.

Durkheim, Emile. The Elementary Forms of the Religious Life. New York: The Free Press, 1965.

Ellis, Charles M. The History of Roxbury Town. Boston: Samuel G. Drake, 1847.

Erben, Patrick M. A Harmony of the Spirits: Translation and the Language of Community in Early Pennsylvania. Chapel Hill: University of North Carolina Press, 2012.

Eusden, John Dykstra. "Introduction," in The Marrow of Theology: William Ames (1576-1633) (Grand Rapids: Baker Books, 1997.

Fisher, Linford D. The Indian Great Awakening: Religion and the Shaping of Native Cultures in Early America (Oxford: Oxford University Press, 2012.

Geertz, Clifford. The Interpretation of Cultures: Selected Essays by Clifford Geertz. New York: Basic Books, Inc., 1973.

Gilpin, W. Clark. The Millenarian Piety of Roger Williams. Chicago: University of Chicago Press, 1979.

Godbeer, Richard. The Devil's Dominion: Magic and Religion in Early New England. Cambridge: Cambridge University Press, 1992.

Goetz, Rebecca Anne. The Baptism of Early Virginia: How Christianity Created Race. Baltimore: Johns Hopkins University Press, 2012.

Gray, Kathryn N. John Eliot and the Praying Indians of Massachusetts Bay: Communities and Connections in Puritan New England. Lewisburg: Bucknell University Press, 2013.

Gregory, Brad S. Salvation at Stake: Christian Martyrdom in Early Modern Europe. Cambridge: Harvard University Press, 1999. 
Griffin, Patrick. American Leviathan: Empire, Nation, and Revolutionary Frontier. New York: Hill and Wang, 2007.

Guissani, Luigi. American Protestant Theology: A Historical Sketch. Montreal: McGill-Queen's University Press, 2013.

Hall, David D. A Reforming People: Puritanism and the Transformation of Public Life in New England. New York: Alfred A. Knopf, 2011.

-------., ed. Puritanism in Seventeenth-Century Massachusetts. New York: Hold Rinehart and Winston, 1968.

------., Worlds of Wonder, Days of Judgment: Popular Religious Belief in Early New England. Cambridge: Harvard University Press, 1989.

Hall, Timothy D. Contested Boundaries: Itinerancy and the Reshaping of the Colonial American Religious World. Durham: Duke University Press, 1994.

Holifield, E. Brooks. Theology in America: Christian Thought from the Age of the Puritans to the Civil War. New Haven: Yale University Press, 2003.

Jones, David Ceri. "A Glorious Work in the World": Welsh Methodism and the International Evangelical Revival, 1735-1750. Cardiff: University of Wales Press, 2004.

Kibbey, Ann. The Interpretation of Material Shapes in Puritanism: A Study of Rhetoric, Prejudice, and Violence. Cambridge: Cambridge University Press, 1986.

Kidd, Thomas S. American Christians and Islam: Evangelical Culture and Muslims from the Colonial Period to the Age of Terrorism. Princeton: Princeton University Press, 2009.

------., God of Liberty: A Religious History of the American Revolution. New York: Basic Books, 2010.

-------, The Great Awakening: A Brief History with Documents. Boston: Bedford/St. Martin's, 2008.

------., The Great Awakening: The Roots of Evangelical Christianity in Colonial America. New Haven: Yale University Press, 2007.

Kopelson, Heather Miyano. Faithful Bodies: Performing Religion and Race in the Puritan Atlantic. New York: New York University Press, 2014.

Lambert, Frank. Inventing the "Great Awakening." Princeton: Princeton University Press, 1999.

------., "Pedlar In Divinity": George Whitefield and the Transatlantic Revivals, 1737-1770. Princeton: Princeton University Press, 1994. 
-------., The Founding Fathers and the Place of Religion in America. Princeton: Princeton University Press, 2003.

Leach, Douglas Edward. Flintlock \& Tomahawk: New England in King Philip's War. Woodstock: Countryman Press, 2009.

Lepore, Jill. The Name of War: King Philip's War and the Origins of American Identity. New York: Vintage Books, 1998.

Little, Ann M. Abraham in Arms: War and Gender in Colonial New England. Philadelphia: University of Pennsylvania Press, 2007.

Lopenzina, Drew. Red Ink: Native Americans Picking Up the Pen in the Colonial Period. Albany: State University of New York Press, 2012.

Lowance, Jr., Mason I. The Language of Canaan: Metaphor and Symbol in New England from the Puritans to the Transcendentalists. Cambridge: Harvard University Press, 1980.

Mandell, Daniel R. Behind the Frontier: Indians in Eighteenth-Century Eastern Massachusetts. Lincoln: University of Nebraska Press, 1996.

------., King Philip's War: Colonial Expansion, Native Resistance, and the End of Indian Sovereignty. Baltimore: Johns Hopkins University Press, 2010.

McClure, David and Elijah Parish. Memoirs of the Rev. Eleazar Wheelock, D.D. [1811] New York: Arno Press, 1972.

McCusker, John J. \& Russel R. Menard. The Economy of British America, 1607-1789. Chapel Hill: University of North Carolina Press, 1985.

Merrell, James H. Into the American Woods: Negotiators on the Pennsylvania Frontier. New York: W.W. Norton \& Company, 1999.

Monaghan, E. Jennifer. Learning to Read and Write in Colonial America. Amherst: University of Massachusetts Press, 2005.

Moore, Martin. Memoirs of the Life and Character of Rev. John Eliot, Apostle of the N.A. Indians. Boston: T. Bedlington, 1822.

Morgan, Edmund S. Visible Saints: The History of a Puritan Idea. Ithaca: Cornell University Press, 1987.

Morison, Samuel Eliot. The Intellectual Life of Colonial New England, $2^{\text {nd }}$ ed. New York: New York University Press, 1956. 
Morrison, Dane. A Praying People: Massachusetts Acculturation and the Failure of the Puritan Mission, 1600-1690. New York: Peter Lang, 1995.

Munk, Linda. The Devil's Mousetrap: Redemption \& Colonial American Literature. Oxford: Oxford University Press, 1997.

Nash, Gary B. Quakers and Politics: Pennsylvania, 1681-1726. New Edition. Boston: Northeastern University Press, 1968.

Natick Federal Savings and Loan Association. The Story of Natick. Natick: Suburban Press, 1948.

O'Brien, Jean M. Community Dynamics in the Indian-English Town of Natick, Massachusetts, 1650-1790. Dissertation: University of Chicago, 1990.

------., Dispossession By Degrees: Indian Land and Identity in Natick, Massachusetts, 1650 1790. Cambridge: Cambridge University Press, 1997.

Pagden, Anthony. The Fall of Natural Man: The American Indian and the Origins of Comparative Ethnology. Cambridge: Cambridge University Press, 1982.

Parmenter, Jon. The Edge of the Woods: Iroquoia, 1534-1701. East Lansing: Michigan State University Press, 2010.

Pestana, Carla G. The English Atlantic in an Age of Revolution, 1640-1661. Cambridge: Harvard University Press, 2004.

------., Protestant Empire: Religion and the Making of the British Atlantic World. Philadelphia: University of Pennsylvania Press, 2009.

Piecuch, Jim. Three Peoples, One King: Loyalists, Indians, and Slaves in the Revolutionary South, 1775-1782. Columbia: University of South Carolina Press, 2008.

Piker, Joshua. Okfuskee: A Creek Indian Town in Colonial America. Cambridge: Harvard University Press, 2004.

Pope, Robert G. The Half-Way Covenant: Church Membership in Puritan New England. Princeton: Princeton University Press, 1969.

Porter, Andrew. Religion versus empire? British Protestant missionaries and overseas expansion, 1700-1914. Manchester: Manchester University Press, 2004.

Preston, David L. The Texture of Contact: European and Indian Settler Communities on the Frontiers of Iroquoia, 1667-1783. Lincoln: University of Nebraska Press, 2009. 
Pulsipher, Jenny Hale. Subjects unto the Same King: Indians, English, and the Contest for Authority in Colonial New England. Philadelphia: University of Pennsylvania Press, 2005.

Richter, Daniel K. Facing East from Indian Country: A Native History of Early America. Cambridge: Harvard University Press, 2001.

Rivett, Sarah. The Science of the Soul in Colonial New England. Chapel Hill: University of North Carolina Press, 2011.

Rubin, Julius H. Tears of Repentance: Christian Indian Identity and Community in Colonial Southern New England. Lincoln: University of Nebraska Press, 2013.

Said, Edward W. Orientalism. New York: Vintage Books, 1979.

Salisbury, Neal. Manitou and Providence: Indians, Europeans, and the Making of New England, 1500-1643. Oxford: Oxford University Press, 1984.

Sayre, Gordon M. Les Sauvages Américains: Representations of Native Americans in French and English Colonial Literature. Chapel Hill: University of North Carolina Press, 1997.

Seed, Patricia. Ceremonies of Possession in Europe's Conquest of the New World, 1492-1640. Cambridge, Cambridge University Press, 1995.

Seeman, Erik R. Pious Persuasions: Laity and Clergy in Eighteenth-Century New England. Baltimore: Johns Hopkins University Press, 1999.

------., The Huron-Wendat Feast of the Dead: Indian-European Encounters in Early North America. Baltimore: John Hopkins University Press, 2011.

Silverman, David J. Faith and Boundaries: Colonists, Christianity, and Community among the Wampanoag Indians of Martha's Vineyard, 1600-1871. Cambridge: Cambridge University Press, 2005.

------., Red Brethren: The Brothertown and Stockbridge Indians and the Problem of Race in Early America. Ithaca: Cornell University Press, 2010.

Simmons, William S. Spirit of the New England Tribes: Indian History and Folklore. Hanover: University Press of New England, 1986.

Stratton, Billy J. Buried in Shades of Night: Contested Voices, Indian Captivity, and the Legacy of King Philip's War. Tucson: University of Arizona Press, 2013.

Stevens, Laura M. The Poor Indians: British Missionaries, Native Americans, and Colonial Sensibility. Philadelphia: University of Pennsylvania Press, 2004. 
Taylor, Alan. The Divided Ground: Indians, Settlers, and the Northern Borderland of the American Revolution. New York: Vintage Books, 2006.

Thomas, R. Murray. Manitou and God: North-American Indian Religions and Christian Culture. Westport: Praeger, 2007.

Tiro, Karim M. The People of the Standing Stone: The Oneida Nation from the Revolution through the Era of Removal. Amherst: University of Massachusetts Press, 2011.

Todorov, Tzvetan. The Conquest of America: The Question of the Other. Translated by Richard Howard. Norman: University of Oklahoma Press, 1984.

Tolles, Frederick B. Meeting House and Counting House: The Quaker Merchants of Colonial Philadelphia, 1682-1763. New York: W.W. Norton \& Company, 1948.

Trigger, Bruce G. Natives and Newcomers: Canada's “Heroic Age” Reconsidered. Montreal: McGill-Queen's University Press, 1985.

Tuck, Richard. The Rights of War and Peace: Political Thought and the International Order from Grotius to Kant. Oxford: Oxford University Press, 2009.

Vaughan, Alden T. New England Frontier: Puritans and Indians 1620-1675. Third Edition. Norman: University of Oklahoma Press, 1995.

------., Transatlantic Encounters: American Indians in Britain, 1500-1776. Cambridge: Cambridge University Press, 2006.

Warren, Jason W. Connecticut Unscathed: Victory in the Great Narragansett War, 1675-1676. Norman: University of Oklahoma Press, 2014.

Weir, David A. Early New England: A Covenanted Society. Grand Rapids: William B. Eerdmans Publishing Company, 2005.

Weber, Max. The Sociology of Religion. Ephraim Fischoff, trans. Boston: Beacon Press, 1964.

White, Richard. The Middle Ground: Indians, Empires, and Republics in the Great Lakes Region, 1650-1815. Twentieth Anniversary Edition. New York: Cambridge University Press, 2011.

Williams, Jr., Robert A. The American Indian in Western Legal Thought: The Discourses of Conquest. Oxford: Oxford University Press, 1990.

Wonderley, Anthony. At the Font of the Marvelous: Exploring Oral Narratives and Mythic Imagery of the Iroquois and Their Neighbors. Syracuse: Syracuse University Press, 2009. 
Wright, Thomas Goddard. Literary Culture in Early New England 1620-1730. New York: Russell \& Russell, 1966.

Wyss, Hilary E. Writing Indians: Literacy, Christianity, and Native Community in Early America. Amherst: University of Massachusetts Press, 2000.

\section{Secondary Sources: Journal Articles and Chapters from Edited Volumes}

Barbour, Reid. "The Caroline Church Heroic: The Reconstruction of Epic Religion in Three Seventeenth-Century Communities." Renaissance Quarterly 50 (1997): 771-818.

Beales, Jr., Ross W. "The Half-Way Covenant and Religious Scrupulosity: The First Church of Dorchester, Massachusetts, as a Test Case." The William and Mary Quarterly 31 (1974): 465-480.

Beaver, R. Pierce. "Methods in American Missions to the Indians in the Seventeenth and Eighteenth Centuries: Calvinist Models for Protestant Foreign Missions." Journal of Presbyterian History 47 (1969): 124-148.

Bellin, Joshua David. “'A Little I Shall Say': Translation and Interculturalism in the John Eliot Tracts." In Reinterpreting New England Indians and the Colonial Experience, edited by Colin G. Calloway \& Neal Salisbury, 52-83. Boston: The Colonial Society of Massachusetts, 2003.

Bellin, Joshua David. “John Eliot’s Playing Indian.” Early American Literature 42 (2007): 1-30.

Beneke, Chris. "The Critical Turn: Jonathan Mayhew, the British Empire, and the Idea of Resistance in Mid-Eighteenth-Century Boston." Massachusetts Historical Review 10 (2008): 23-56.

Blair, Anthony L. "Shattered and Divided: Itinerancy, Ecclesiology, and Revivalism in the Presbyterian Awakening." The Journal of Presbyterian History 81 (2003): 18-34.

Blosser, Jacob M. “John Tillotson's Latitudinarian Legacy: Orthodoxy, Heterodoxy, and the Pursuit of Happiness." Anglican and Episcopal History 80 (2011): 142-173.

Breen, Louise A. "Praying with the enemy: Daniel Gookin, King Philip's War, and the dangers of intercultural mediatorship." In Empire and Others: British Encounters with Indigenous Peoples, 1600-1850, edited by Martin Daunton and Rick Halpern, 101-122. Philadelphia, University of Pennsylvania Press, 1999.

David C. Brown, "The Keys of the Kingdom: Excommunication in Colonial Massachusetts," The New England Quarterly 67 (1994): 531-566. 
Brown, Anne S. and David D. Hall. "Family Strategies and Religious Practice: Baptism and the Lord's Supper in Early New England." In Lived Religion in America: Toward a History of Practice, edited by David D. Hall, 41-68. Princeton: Princeton University Press, 1997.

Brown, Kathleen. "Native Americans and early modern concepts of race." In Empire and Others: British Encounters with Indigenous Peoples, 1600-1850, edited by Martin Daunton and Rick Halpern, 79-100. Philadelphia: University of Pennsylvania Press, 1999.

Canny, Nicholas. "A Protestant or Catholic Atlantic World? Confessional Divisions and the Writing of Natural History." Proceedings of the British Academy 181 (2012): 83-121.

Burkholder, Jared S. "This 'rends in Pieces all the Barriers between Virtue and Vice': Tennentists, Moravians, and the Antinomian Threat in the Delaware Valley." The Pennsylvania Magazine of History and Biography 135 (2011): 5-31.

Cesarini, J. Patrick. "John Eliot's 'A Breif History of the Mashepog Indians,' 1666." The William and Mary Quarterly 62 (2008): 101-134.

-------., “What Has Become of Your Praying to God?” Daniel Gookin's Troubled History of King Philip's War.” Early American Literature 44 (2009): 489-515.

Cogley, Richard W. "A Presbyterian in Congregationalist New England? The Case of John Eliot," The Journal of Presbyterian History 77 (1997): 71-79.

-------., "John Eliot and the Millennium.” Religion and American Culture: A Journal of Interpretation 1 (1991): 227-250.

Cooper, Jr., James F., "Higher Law, Free Consent, Limited Authority: Church Government and Political Culture in Seventeenth-Century Massachusetts," The New England Quarterly 69 (1996): 201-222.

Crome, Andrew. "Constructing the Political Prophet in 1640s England." Seventeenth Century 26 (2011): 279-298.

Ditchfield, Simon. "Thinking with Saints: Sanctity and Society in the Early Modern World." Critical Inquiry 35 (2009): 552-584.

Doughton, Thomas "Unseen Neighbors: Native Americans of Central Massachusetts, A People Who Had 'Vanished."' In After King Philip's War: Presence and Persistence in Indian New England, edited by Colin G. Calloway, 207-230. Hanover: University Press of New England, 1997.

Drake, James. "Symbol of a Failed Strategy: The Sassamon Trial, Political Culture, and the Outbreak of King Philip's War.” American Indian Culture and Research Journal 19 (1995): 111-141. 
Elrod, Eileen Razzari. “'I Did Not Make Myself So . . .': Samson Occom and American Religious Autobiography." In Christian Encounters With the Other, edited by John C. Hawley, 135-149. Washington Square: New York University Press, 1998.

Fisher, Linford D. 'I Believe They are Papists!': Natives, Moravians, and the Politics of Conversion in Eighteenth-Century Connecticut." The New England Quarterly 81 (2008): $410-437$.

------., “'It Provd But Temporary, \& Short Lived': Pequot Affiliation in the First Great Awakening." Ethnohistory 59 (2012): 465-488.

Fiering, Norman. "The First American Enlightenment: Tillotson, Leverett, and Philosophical Anglicanism.” New England Quarterly 54 (1981): 307-344.

Foster, Frank Hugh. "The History of the Original Puritan Theology of New England, 16201720." The American Journal of Theology 1 (1897): 700-727.

Gehren, Christopher. "New Guinea: Racial Identity and Inclusion in the Stockbridge and Brothertown Indian Communities of New York.” New York History 90 (2009): 141-166.

Gerbner, Katherine. "Beyond the Halfway Covenant: Church Membership, Extended Baptism, and Outreach in Cambridge, Massachusetts, 1656-1667." New England Quarterly 85 (2012): 281-301.

Gloege, Timothy E.W. "The Trouble with Christian History: Thomas Prince's Great Awakening." Church History 82 (2013): 125-165.

Katheryn N. Gray, “'How may wee come to serve God?': Spaces of Religious Utterance in John Eliot's Indian Tracts," Seventeenth Century 24 (2009): 74-96.

Gregerson, Linda. "The Commonwealth of the Word: New England, Old England, and the Praying Indians." In Empires of God: Religious Encounters in the Early Modern Atlantic, edited by Linda Gregerson and Susan Juster, 70-83. Philadelphia: University of Pennsylvania Press, 2011.

Crawford Gribben. "The Church of Scotland and the English Apocalyptic Imagination, 1630 to 1650." The Scottish Historical Review 88 (2009): 34-56.

Grigg, John. “"A Principle of Spiritual Life': David Brainerd's Surviving Sermon,” The New England Quarterly 77 (2004): 273-282.

Gura, Philip F. "Preparing the Way for Stoddard: Eleazar Mather's Serious Exhortation to Northampton." The New England Quarterly 57 (1984): 240-249. 
Haefeli, Evan and Kevin Sweeny. "Revisiting The Redeemed Captive: New Perspectives on the 1704 Attack on Deerfield." In After King Philip's War: Presence and Persistence in Indian New England, edited by Colin G. Calloway, 29-71. Hanover: University Press of New England, 1997.

Harvey, Sean P. “An Eighteenth-Century Linguistic Borderland.” The Pennsylvania Magazine of History and Biography 136 (2012): 495-498.

Herndon, Ruth Wallis and Ella Wilcox Sekatau." Colonizing the Children: Indian Youngsters in Servitude in Early Rhode Island." In Reinterpreting New England Indians and the Colonial Experience, edited by Colin G. Calloway \& Neal Salisbury, 136-173. Boston: The Colonial Society of Massachusetts, 2003.

Holifield, E. Brooks. “On Toleration in Massachusetts.” Church History 38 (1969): 188-200.

Holstun, James. “John Eliot's Empirical Millenarianism.” Representations 4 (1983): 128-153.

Jalalzai, Zubeda. "Race and the Puritan Body Politic,” MELUS 29 (2004), 259-272.

Jennings, Francis. "Goals and Functions of Puritan Missions to the Indians." Ethnohistory 18 (1971): 197-212.

Johnson, Warren. "The Anglican Apocalypse in Restoration England." The Journal of Ecclesiastical History 55 (2004): 467-501.

Knapp, Henry M. "The Character of Puritan Missions: The Motivation, Methodology, and Effectiveness of the Puritan Evangelization of the Native Americans in New England." The Journal of Presbyterian History 79 (1998): 111-126.

Lindman, Janet Moore. "'Bad Men and Angels from Hell': The Discourse of Universalism in Early National Philadelphia." Journal of the Early Republic 31 (2011): 259-282.

Mark Garrett Longaker, "Puritan Sermon Method and Church Government: Solomon Stoddard's Rhetorical Legacy," The New England Quarterly 79 (2006): 439-460.

Lopenzina, Drew. "“The Whole Wilderness Shall Blossom as the Rose': Samson Occom, Joseph Johnson, and the Question of Native Settlement on Cooper's Frontier." American Quarterly 58 (2006): 1119-1145.

Lucas, Paul R. "Presbyterianism Comes to Connecticut: The Toleration Act of 1669." Journal of Presbyterian History 50 (1972): 129-147.

Mancall, Peter C. "Men, Women, and Alcohol in Indian Villages in the Great Lakes Region in the Early Republic." Journal of the Early Republic 15 (1995): 425-448. 
McAllister, Edwin J. “'Our Glory and Joy’: Stephen Riggs and the Politics of NineteenthCentury American Missionary Ethnography Among the Sioux." In Christian Encounters with the Other, edited by John C. Hawley, 150-164. Washington Square: New York University Press, 1998.

Merritt, Jane T. "Dreaming of the Savior's Blood: Moravians and the Indian Great Awakening in Pennsylvania." The William and Mary Quarterly 54 (1997): 723-746.

Michaelsen, Scott. “John Winthrop's 'Modell' Covenant and the Company Way," Early American Literature 27 (1992): 85-100.

Miller, Joshua. "Direct Democracy and the Puritan Theory of Membership," The Journal of Politics 53 (1991): 57-74.

Moran, Gerald F. "Religious Renewal, Puritan Tribalism, and the Family in Seventeenth-Century Milford, Connecticut." The William and Mary Quarterly 36 (1979): 236-254.

John Morrill. "The Religious Context of the English Civil War.” Transactions of the Royal Historical Society 34 (1984): 155-178.

Morrison, Kenneth M. "“That Art of Coyning Christians:' John Eliot and the Praying Indians of Massachusetts." Ethnohistory 21 (1974): 77-92.

Murray, Laura. “'Pray Sir, Consider a Little': Rituals of Subordination and Strategies of Resistance in the Letters of Hezekiah Calvin and David Fowler to Eleazar Wheelock, 1764-1768." Studies in American Indian Literatures 4 (1992): 48-74.

Myles, Anne G. "Restoration Declensions, Divine Consolations: The Work of John Foxe in 1664 Massachusetts." The New England Quarterly 80 (2007): 35-68.

Naeher, Robert James. "Dialogue in the Wilderness: John Eliot and the Indian Exploration of Purtianism as a Source of Meaning, Comfort, and Ethnic Survival." The New England Quarterly 62 (1989): 346-368.

Newell, Margaret Ellen. "The Changing Nature of Indian Slavery in New England, 1670-1720." In Reinterpreting New England Indians and the Colonial Experience, edited by Colin G. Calloway \& Neal Salisbury, 106-136. Boston: The Colonial Society of Massachusetts, 2003.

O’Brien, Jean M. “"They are so frequently shifting their place of residence': Land and the Construction of Social Place of Indians in Colonial Massachusetts." In Empire and Others: British Encounters with Indigenous Peoples, 1600-1850, edited by Martin Daunton and Rick Halpern, 204-216. Philadelphia: University of Pennsylvania Press, 1999. 
O'Connell, Barry. “'Once More Let Us Consider': William Apess in the Writing of New England Native American History." In After King Philip's War: Presence and Persistence in Indian New England, edited by Colin G. Calloway, 162-177. Hanover: University Press of New England, 1997.

Orsi, Robert. "Everyday Miracles: The Study of Lived Religion." In Lived Religion in America: Toward a History of Practice, edited by David D. Hall, 3-21. Princeton: Princeton University Press, 1997.

Parker, David L. "Edward Taylor's Preparationism: A New Perspective on the Taylor-Stoddard Controversy." Early American Literature 11 (1976): 259-278.

Jason Peacey. "Print Culture and Political Lobbying during the English Civil Wars." Parliamentary History 26 (2007): 30-48.

Pope, Robert G. "New England versus the New England Mind: The Myth of Declension," Journal of Social History 3 (1969): 95-108.

Prior, Charles W.A. "Religion, Political Thought and the English Civil War." History Compass 11 (2013) 24-42.

Pulsipher, Jenny Hale. "Massacre at Hurtleberry Hill: Christian Indians and English Authority in Metacom's War." The William and Mary Quarterly 53 (1996): 459-486.

Randall, Ian M. "A Missional Spirituality: Moravian Brethren and eighteenth-century English evangelicalism.” Transformation 23 (2006): 204-214.

Rex, Cathy. "Indians and Images: The Massachusetts Bay Colony Seal, James Printer, and the Anxiety of Colonial Identity," American Quarterly 63 (2011): 61-93.

Salisbury, Neal. "Red Puritans: The 'Praying Indians' of Massachusetts Bay and John Eliot." The William and Mary Quarterly 31 (1974): 27-54.

Schneider, Deborah Lucas. "Anne Hutchinson and Covenant Theology," Harvard Theological Review 103 (2010): 485-500.

Scheick, William J. “An Inward Power and Authority: John Davenport's Seditious Piety.” Religion \& Literature 33 (2001): 1-21.

Schneider, Tammy. “'This Once Savage Heart of Mine': Joseph Johnson, Wheelock's 'Indians,' and the Construction of a Christian/Indian Identity, 1764-1776." In Reinterpreting New England Indians and the Colonial Experience, edited by Colin G. Calloway \& Neal Salisbury, 232-263. Boston: Colonial Society of Massachusetts, 2003.

Schweber, Howard. "Ordering Principles: The Adjudication of Criminal Cases in Puritan Massachusetts, 1629-1650.” Law \& Society Review 32 (1998): 367-408. 
Seeman, Erik R. 'Reading Indians' Deathbed Scenes: Ethnohistorical and Representational Approaches." The Journal of American History 88 (2001): 17-47.

Seligman, Adam. "Inner-Worldly Individualism and the Institutionalization of Puritanism in Late Seventeenth-Century New England.” The British Journal of Sociology 41 (1990): 537557.

Silverman, David J. "Indians, Missionaries, and Religious Translation: Creating Wampanoag Christianity in Seventeenth-Century Martha's Vineyard." The William and Mary Quarterly 62 (2005): 141-174.

-------, "The Church in New England Indian Community Life: A View From the Islands and Cape Cod." In Reinterpreting New England Indians and the Colonial Experience, edited by Colin G. Calloway and Neal Salisbury, 264-298. Boston: The Colonial Society of Massachusetts, 2003.

-------, “The Curse of God: An Idea and Its Origins among the Indians of New York's Revolutionary Frontier." The William and Mary Quarterly 66 (2009): 495-534.

Sommerville, C.J. “Conversion versus the Early Puritan Covenant of Grace.” Journal of Presbyterian History 44 (1966): 178-197.

Szasz, Margaret Connell. "“Poor Richard' Meets the Native American: Schooling for Young Indian Women in Eighteenth-Century Connecticut." Pacific Historical Review 49 (1980): 215-235.

Tanis, Norman Earl. “Education in John Eliot's Indian Utopias, 1646-1675." History of Education Quarterly 10 (1970): 308-323.

Templer, Bill. “The Political Sacralization of Imperial Genocide: Contextualizing Timothy Dwight's The Conquest of Cannan.” Postcolonial Studies 9 (2006): 358-391.

Thomson, David. "The Antinomian Crisis: Prelude to Puritan Missions," Early American Literature 38 (2003): 401-435.

Thomas, G.E. "Puritans, Indians, and the Concept of Race," The New England Quarterly 48 (1975): 3-27.

Tucker, Bruce. “The Reinvention of New England, 1691-1770.” New England Quarterly 59 (1986): 315-340.

Nicholas Tyacke. "The Puritan Paradigm of English Politics, 155-1642." The Historical Journal 53 (2010): 527-550. 
Valerius, Karyn. “'So Manifest a Signe from Heaven': Monstrosity and Heresy in the Antinomian Controversy," The New England Quarterly 83 (2010): 179-199.

Valone, Stephen. "Samuel Kirkland, Iroquois Missions and the Land, 1764-1774." American Presbyterians 65 (1987): 187-194.

Vaughan, Alden T. "From White Man to Redskin: Changing Anglo-American Perceptions of the American Indian.” The American Historical Review 87 (1982): 917-953.

Vickers, Daniel. "The First Whalemen of Nantucket." In After King Philip's War: Presence and Persistence in Indian New England, edited by Colin G. Calloway, 90-113. Hanover: University Press of New England, 1997.

Wiggington, Caroline. "Extending Root and Branch: Community Regeneration in the Petitions of Samson Occom.” Studies in American Indian Literatures 20 (2008): 24-55.

Willen, Diane. "CCommunion of the Saints': Spiritual Reciprocity and the Godly Community in Early Modern England," Albion: A Quarterly Journal Concerned with British Studies 27 (1995): 19-41.

Winiarski, Douglas L. "Jonathan Edwards, Enthusiast? Radical Revivalism and the Great Awakening in the Connecticut Valley." Church History 74 (2005): 683-739.

------., 'Native American Popular Religion in New England's Old Colony, 1670-1770." Religion and American Culture: A Journal of Interpretation 15 (2005): 147-186.

Winship, Michael P. “What Puritan Guarantee?” Early American Literature 47 (2012): 411-420.

Witzig, Fred. 'Beyond Expectation: How Charles Town's 'Pious and Well-Disposed Christians' Changed their Minds About Slave Education During the Great Awakening." The South Carolina Historical Magazine 114 (2013): 286-315.

Wolverton, Nan. “'A Precarious Living': Basket Making and Related Crafts Among New England Indians." In Reinterpreting New England Indians and the Colonial Experience, edited by Colin G. Calloway \& Neal Salisbury, 341-368. Boston: The Colonial Society of Massachusetts, 2003.

Wood, Joseph S. “'Build, Therefore, Your Own World': The New England Village as Settlement Ideal," Annals of the Association of American Geographers 81 (1991): 32-50.

Wyss, Hilary E. "Mary Occom and Sarah Simon: Gender and Native Literacy in Colonial New England." The New England Quarterly 79 (2006): 387-412.

Young, Ralph. F. "Breathing the 'Free Aire of the New World': The Influence of the New England Way on the Gathering of Congregational Churches in Old England, 1640-1660." The New England Quarterly 83 (2010): 5-46. 